YMP $-90-38$

DE9 1006824

\author{
STATUS OF DATA, MAJOR RESULTS, AND PLANS \\ FOR GEOPHYSICAI ACTIVITIES, \\ YUCCA MOUNTAIN PROJECT
}

\author{
Editors \\ H.W. Oliver (USGS, Menlo Park, California) \\ E.I. Hardin (SAIC, Las Vegas, Nevada) \\ P.H. Nelson (USGS, Denver, Colorado)
}

July 1990

Prepared for the U.S. Department of Energy by the United States Geological Survey and Science Applications International Corporation.

\title{
MASTER
}

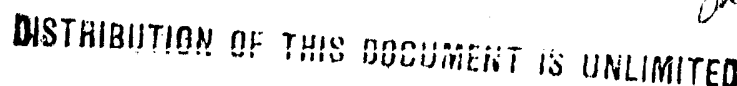


This report was prepared as an account of work sponsored by the United States Government. Neither the United States nor the United States Department of Energy, nor any of their employees, makes any warranty, expressed or implied, or assumes any legal liability or responsibility for the accuracy, completeness, or usefulness of any information, apparatus, product, or process disclosed, or represents that its use would not infringe privately owned rights. Reference herein to any specific comercial product, process, or service by trade name, mark, manufacturar, or otherwise, does not necessarily constitute or imply its endorsement, recommendation, or favoring by the United States Government or any agency thereof. The views and opinions of authors expressed herein do not necessarily state or reflect those of the United States Government or any agency thereof.

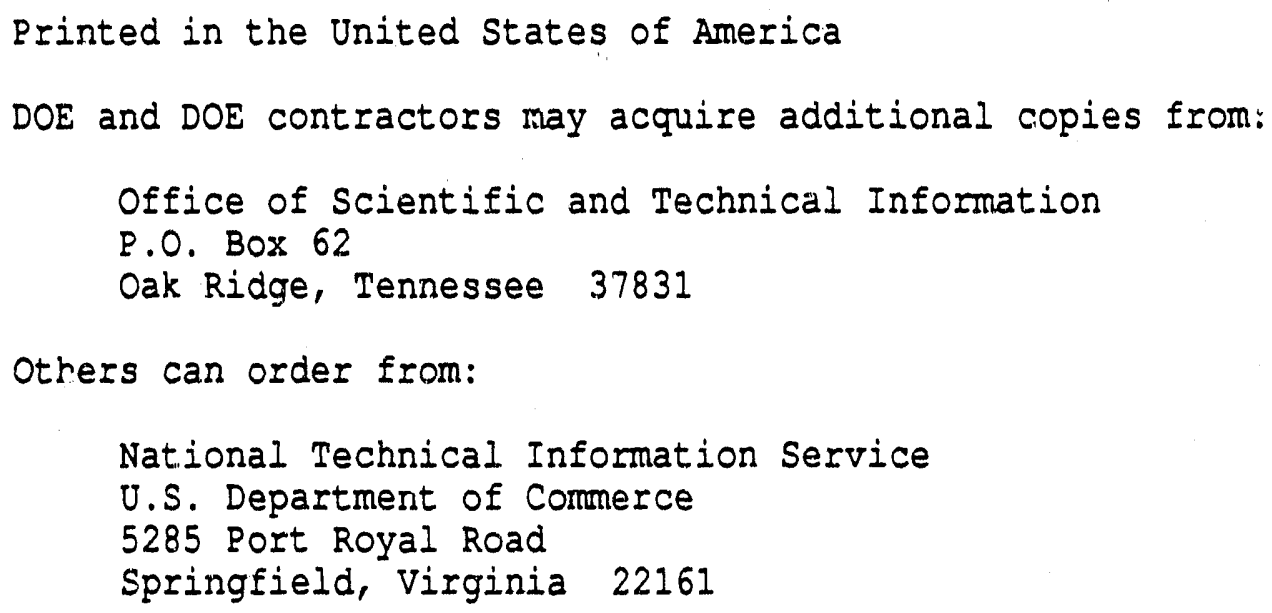


1.0 INTRODUCTION . . . . . . . . . . . . . . . . . . . . . . 1

Scope of This Report . . . . . . . . . . . . . . . . . . . . 1

Maps and Geologic Units . . . . . . . . . . . . . . . . . . 2

2.0 PAST GEOPHYSICAL ACTIVITIES . . . . . . . . . . . . . . 5

2.1 Gravity Investigations . . . . . . . . . . . . . . . . . 5

Objectives... . . . . . . . . . . . . . . . . 5

Data Coverage and Quality (Gravity Measurements) . . . . . . . . . 5

Data Coverage and Quality (Density Data) . . . . . . . . . . . . 11

Summary of Results.................... . . 11

Bibliography . . . . . . . . . . . . . . . . . 13

2.2 Magnetic and Paleomagnetic Investigations . . . . . . . . . . . 17

Objectives . . . . . . . . . . . . . . . . . . . 17

Data Coverage and Quality . . . . . . . . . . . . . . . 17

Ground Magnetic Data.................. . . 23

Paleomagnetic and Rock Magnetic Studies . . . . . . . . . 23

Summary of Results . . . . . . . . . . . . . . . . . 25

Bibliography . . . . . . . . . . . . . . . . . . 28

2.3 Geoelectric Surveys . . . . . . . . . . . . . . . . . 33

Objectives . . . . . . . . . . . . . . . . . . . . 33

Data Coverage and Quality . . . . . . . . . . . . . . 33

Sumary of Results...................... 34

Bibliography ....................... . . . 45

2.4 Seismic Refraction Surveys . . . . . . . . . . . . . . . . 47

Objectives................... . . . . 47

Data Coverage and Quality . . . . . . . . . . . . . . 47

Summary of Results.... . . . . . . . . . . . . . 52

Bibliography . . . . . . . . . . . . . . . . . . 55

2.5 Seismic Reflection Surveys . . . . . . . . . . . . . . . . . 57

2.5.1 Shallow, High-Resolution Reflection Profiling........ 57

Objectives .................... 57

Data Coverage and Quality .. . . . . . . . . . . 60

Summary of Results ................... 65

2.5.2 Intermediate-Depth Reflection Surveys . . . . . . . . . 66

Objectives ................... 66

Data Coverage and Quality... . . . . . . . . . 66

Summary of Results .................. 70

2.5 .2 Deep Reflection Profiles . . . . . . . . . . . . 70

Objectives ..................... . . . 70

Data Coverage and Quality .............. . . 71

Bibliography

Summary of Results . . . . . . . . . . . . . 72 
2.6 Remote Sensing and Aerial Gamma-Ray Surveys . . . . . . . . . . . . 75

2.6.1 Remote Sensing . . . . . . . . . . . . . . . . . . 75

Objectives . . . . . . . . . . . . . . . 75

Data Coverage and Quality ....... . . . . . . . 75

Surtmary of Results ... . . . . . . . . . . . . 76

Bibliography ....... . . . . . . . . . . . . 77

2.6.2 Aerial Gama-Ray Surveys Over the Nevada Test Site . . . . . 81

Objectives ..................... 81

Data Coverage and Quality . . . . . . . . . . . . . 81

Summary of Results . . . . . . . . . . . . . . 82

Bibliography .................... 82

2.7 Borehole Geophysics and Petrophysical Measurements . . . . . . . . . 85

Objectives....................... . . . . 85

Data Coverage and Quality . . . . . . . . . . . . . . 85

Sumary of Results...................... . . 86

Fracture Detection/Characterization . . . . . . . . . . . 93

Neutron Moisture Meter Logging ... . . . . . . . . . . . . . 93

Other Slim-Hole Moisture Logging . . . . . . . . . . . . . . . 94

Related Infiltration Data from Borehole Geophysics . . . . . . . 95

Bibliography . . . . . . . . . . . . . . . . . 95

2.8 Teleseismic Tomography Surveys . . . . . . . . . . . . . . . 99

Objectives . . . . . . . . . . . . . . . . . . 99

Data Coverage and Quality .. . . . . . . . . . . . . 99

Sumary of Results...................... 101

Bibliography ........................ 102

3.0 PIANNED GEORHYSICAL ACTIVITIES . . . . . . . . . . . . . . 105

3.1 Discussion of Planned Geophysical Activities . . . . . . . . . . . 115

3.1.1 Unsaturated Zone Hydrologic Investigations . . . . . . . . . 115

Fax-Field Characteristics from Vertical Seismic Profiling . 115

Formation Characteristics near the Borehole, from Geophysical logging ................... 116

Borehole, Crosshole, and Surface-to-Borehole Methods . . 118

Remote Sensing ................... 118

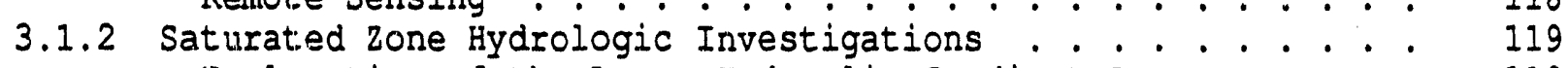

Exploration of the Large Hydraulic Gradient Area .. . . . 119

Investigation of Recharge in Stream Washes . . . . . . . 123

Fracture Characterization in the Saturated zone...... . 124

Regional Characterization of Cenozoic and Paleozoic Rocks . 125

3.1.3 Geophysical Characterization of Mineral and Energy

Resources........................ 126

3.1 .4 Geophysical Studies for Geology and Tectonics. . . . . . . 130

Regional Geophysical Studies . . . . . . . . . . . 130

Regional Geophysical Lines .. . . . . . . . . . . . 131

Detection/Characterization of Faults in the Yucca

Mountain Region................. 132

Characterization of volcanic Features . . . . . . . . . 137 
Teleseismic . . . . . . . . . . . . . 137

Support of Paleoclimate Studies . . . . . . . . . . . . 138

3.1.5 Geophysical Studies in the Site Area, for Geology and

Tectonics . . . . . . . . . . . . . . . . . . . . . . 139

Structure and Stratigraphy . . . . . . . . . . . . . . 139

Detailed Gravity . . . . . . . . . . . . . . . . . . . . 139

Aeromagnetic and Ground Magnetic Surveys . . . . . . . . 142

Geoelectric Methods . . . . . . . . . . . . . . . . . . 143

Radioactivity and Remote Sensing . . . . . . . . . . . . 143

Seismic Reflection . . . . . . . . . . . . . . . . . 144

Seismic Refraction . . . . . . . . . . . . . . . . . 145

Characterization of Fractures and Faults in the Repository

Block ...................... 146

Borehole Geophysics . . . . . . . . . . . . . . . 146

EM Tomography . . . . . . . . . . . . . . . . . . 146

Vertical Seismic Profiling . . . . . . . . . . . . . . 147

3-D Characterization of Lithology and Hydrologic State of

the Repository Block . . . . . . . . . . . . . . . . 148

Borehole Geophysics . . . . . . . . . . . . . . . . . . . 148

3.1.6 Engineering Geophysics for Surface Facilities Siting . . . . 149

Trenching and Ground Penetrating Radar in Midway Valley . . 150

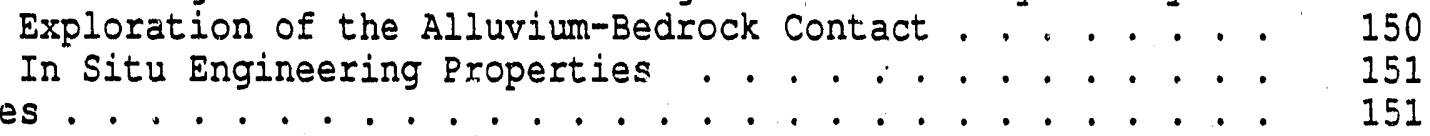

3.2 Geophysical Integration and Prioritization of Activities . . . . . 155

Interfaces Between Studies . . . . . . . . . . . . . . . . 156

NRC Site Characterization Analysis (SCA) Concerns . . . . . . . . 156

Activity Prioritization . . . . . . . . . . . . . . . . . . 165

Subsurface Structure of the Yucca Moluntain Site Area and

Region....................... 166

Distribution of Volcanic Deposits .............. 168

Exploration of the Large Hydraulic Gradient Area . . . . . . . . 169

Characterization of Fractures and Fault Zones in the Repository

Block . . . . . . . . . . . . . . . . . . . . 170

Exploration of the Proposed Exploratory Shaft Location. . . . . 171

Assessment of the Potential for Natural Resources . . . . . . . 171

Feasibility Test Plan - Geophysics Integration and Feasibility

Testing . . . . . . . . . . . . . . . . . 171

Sumary ....................... 172

3.3 Feasibility Tests . . . . . . . . . . . . . . . . 175

3.4 QA Requirements for issing Data from Past Geophysical Activities . . 181

Introduction . . . . . . . . . . . . . . . . . . . . 181

NRC-Defined Data Qualification Methods . . . . . . . . . . . 182

The Qualification Process . . . . . . . . . . . . . . . 183

Candidate Data Sets for Qualification . . . . . . . . . . . . 184

References . . . . . . . . . . . . . . . . 186 
4.0 SUMMARY AND CONCLUSIONS . . . . . . . . . . . . . . . . . . 189

5.0 ACKNOWLEDGMENTS . . . . . . . . . . . . . . . . . . . . . 191

APPENDIX A - TABLE OF CONTENTS FOR VOLUMES IV AND V OF THE SITE

CHARACTERIZATION PLAN (SECTION 8.0 - SECTION 8.3.1.17.5) (DOE/RW-0199, DECEMBER 1988)

$A-1$

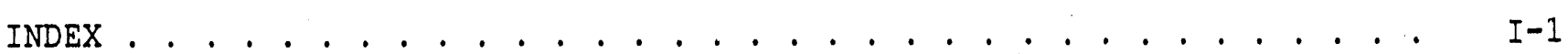




\section{IIST OF EIGURES}

Figure

Title

Page

2.1-1 Distribution of gravity stations in the Yucca Mountain

region. . . . . . . . . . . . . . . . . . . . . .

2.1-2 Distribution of gravity stations in the Yucca Mountain site area . . . . . . . . . . . . . . . . . . . . .

2.2-1 Aeromagnetic index map of regional study area showing flight line spacing of available data . . . . . . . . . . . . . . .

2.2-2. Aeromagnetic index map of site area and vicinity showing the locations of available surveys . . . . . . . . . . . . . . .

2.3-1 Location of geoelectric surveys in the Yucca Mountain region, including the Nevada Test Site, southern Nevada . . . . . .

2.3-2 Iocation of geoelectric traverses in the Yucca Mountain site area .........................

Location of Schlumberger resistivity soundings acquired by Greenhaus and Zablocki (1982)

2.4-1 Map of Yucca Mountain refraction lines from Pankratz (1982).

2.4-2 Map of the Yucca Mountain region showing the locations of five high resolution upper-crustal seismic refraction profiles .

2.5-1 Location of seismic reflection surveys reported by McGovern (1983) for the Yucca Mountain site area . . . . . . . . . . .

2.5-2 Iocation of seismic reflection lines in the Yucca Mountain region, acquired by the Yucca Mountain Project, or by the oil-and-gas industry for speculative purposes . . . . . . .

2.7-1 Map of boreholes in the Yucca Mountain site area from which geophysical logs have been acquired by the Yucca Mountain Project . . . . . . . . . . . . . . . . . . . .

2.8-1 Maps of seismograph stations used in teleseismic tomography studies . . . . . . . . . . . . . . . . . . .

3.1-1 Map of Yucca Mountain, showing the location of planned magnetotelluric soundings, which will be used to investigate the large hydraulic gradient . . . . . . . . . . . . . . .

3.1-2 Planned regional geophysical traverses with tentative deep and intermediate depth seismic reflection lines added...

3.1-3 Planned shallow seismic reflection (Mini-Sosie) lines for assessment of method, and for investigation of faults in the Yucca Mountain region 


\section{LIST OF FIGURES (continued)}

Figure

Title

$\underline{\text { Page }}$

3.1-4 Tentatively planned deep (and intermediate-depth) seismic reflection profiles across Yucca Mountain, and in the immediate vicinity . . . . . . . . . . . . . . . .

3.1-5 Approximate coverage for planned detailed gravity and detailed aeromagnetic surveys . . . . . . . . . . . . . .

3.2-1 Matrix correlating categories of geophysical methods, with SCP studies wherein geophysical data will be collected and used 
2.1-1 Regional gravity maps of various areas within the regional study area .. . . . . . . . . . . . . . . .

2.1-2 Density and thickness of selected geologic units in the Yucca Mountain area ... . . . . . . . . . . . . .

2.2-1 Aeromagnetic surveys all or partly within the Yucca Mountain site area and vicinity................ 18

2.2-2 Magnetic properties of volcanic stratigraphy at the site . . 26

2.3-1 Geonlectric investigations on Yucca Mountain . . . . . . . 39

2.5-1 Existing seismic reflection data and past surveys . . . . . 58

2.7-1 Log types in each drillhole ............. 89

2.7-2 Petrophysical data from Yucca Mountain boreholes . . . . . . 91

3.1-1 Sunmary of planned geophysical activities . . . . . . . 107

3.2-1 Interfaces between geophysical activities, arranged by SCP activity . . . . . . . . . . . . . . . 158

3.2-2 Summary of high-priority geophysical activities ... . . . . 173

3.3.1 Geophysical feasibility tests . . . . . . . . . . . . 177 
REPORT ON GEORHYSICR _ ACTIVITIES FOR THE YUCCA MOUNTAIN PROJECT

\subsection{INTRODUCTION}

This report describes past and planned geophysical activities associated with the Yucca Mountain Project and is intended to serve as a starting point for integration of geophysical activities. Geophysical surveys were conducted at Yucca Mountain as early as 1978, when repository siting investigations in the Nevada Test site (NTS) area were begun. This report relates past results to site characterization plans, as presented in the Yucca Mountain Site Characterization Plan (SCP). As indicated in the SCP, many geophysical activities have not been planned explicitly or in detail because of uncertainty as to the applicability of various methods. A characterization activity was incorporated in the SCP to structure the evaluation and planning of geophysical activities during site characterization (SCP Section 8.3.1.4.1.2). This integration activity is tasked with reducing the uncertainty attendant to the application of geophysical methods. This report ("white paper") is a preparation for that activity. Whereas this report identifies some new exploration concepts and elaborates on some activity descriptions in the SCP, if changes are made to the scope of work described by the SCP, they will be made in accordance with change-control procedures.

Importantly, this report does not present geophysical data or interpretation. Rather, only survey coverage, data quality, and applicability of results to site characterization are discussed, as a means to relate past and planned activities. Extensive references to data and interpretive reports are provided, including many not direstly cited in this report. Several such reports are currently in preparation and could not be referenced, including one summarizing regional geophysics, one summarizing geophysical logging at Yucca Mountain, and one describing teleseismic tomography based on data collected in 1982 .

The SCP contains a number of studies and activities that wi.ll use relatively new geophysical methods, or methods that have not been applied in volcano-tectonic settings such as Yucca Mountain. The need to try these is based on the prospect that they may yield information of sufficient quality to be of significant value in site characterization. Both the SCP and this report emphasize plans for feasibility testing, on the basis that the cost 0. such testing is outweighed by the potential gain in added confidence of characterization of site conditions.

\section{SCOPE OF THIS REPORT}

This report discusses seismic exploration, potential field methods, geoelectrical methods, teleseismic data collection and velocity structural modeling, and remote sensing. The following are important areas of investigation that are discussed in the SCP, but are excluded from direct consideration in this report for reasons of expediency: geodesy and strain monitoring, periodic remeasurement of gravity stations over the long term, teleseismic monitoring for ground-motion studies (as opposed to tomography, 
which is included), heat flow measurements, and borehole stress measurement. This report discusses surface-based, airborne, borehole, surface-to-borehole, crosshole, and Exploratory Shaft Facility-related activities. The data described in this paper, and the publications discussed, have been selected based on several considerations: location with respect to Yucca Mountain, whether the success or failure of geophysical data is important to future activities, elucidation of features of interest, and judgment as to the likelihood that the method will produce information that is important for site characterization.

MAPS AND GEOLOGIC UNITS

The maps used in this report are, with one exception, presented on consistent regional and site area base maps. The regional base was prepared by considering a $100 \mathrm{~km}$ radius around the site, then extending the map boundaries to the nexc 0.5 degree increment of latitude and longitude (see for example, Figure 2.1-1). Physiographic information was included by shading within selected elevation contours, which encompass particular features, and labeling those features. Various different elevation contours were used. The site area base (e.g., Figure 2.3-2) covers from $116^{\circ} 22^{\prime} \mathrm{W}$ to $116^{\circ} 30^{\prime} \mathrm{W}$, and from $36^{\circ} 45^{\prime} \mathrm{N}$ to $36^{\circ} 55^{\prime} \mathrm{N}$. This quadrangle includes the conceptual boundaries of the repository perimeter drift and the controlled area. Topographic $50-\mathrm{m}$ contours were obtained from the U.S. Geological Survey (USGS) 1:100,000 Beatty CA/NV quadrangle, and labels were provided for certain physiographic features.

These boundaries were adopted for purposes of presenting planned site characterization activities in this report. Geophysical activities will investigate areas beyond arbitrary boundaries as necessary.

The stratigraphic units used in this report are consistent with those of the SCP, particularly Section 1.2.2 (lithostratigraphy) and Section 3.9 (hydrogeologic stratigraphy). Lithnstratigraphic information is also contained in Tables 2.1-2 and 2.2-2 of this report. In general, this report refers to lithostratigraphy when discussing geologic and tectonic applications, and hydrogeologic stratigraphy when discussing hydrologic applications. (The discussion is not particularly sensitive to the differences between the stratigraphic systems.)

A description of the stratigraphy and general characteristics of the unsaturated, repository block is provided here for the convenience of the reader. Briefly, the tuff sequence consists of several tuff units that were erupted from nearby volcanic centers in Miocene time, and have since undergone structural deformaticn. The total thickness of tuff varies, but is more than 1,200 $\mathrm{m}$ over most of the site area. Tuff lithology ranges from nonwelded to densely welded, corresponding to a matrix porosity range of roughly $30 \%$ to 5\%, respectively. Mineralogical differences are superimposed on welding, depending on source magma composition, rapidity of cooling, flow thickness, and secondary alteration that is probably associated with ground water. Much of the welded tuff is pervaded by mineralized, interconnected macropores (lithophysae). These were formed from the action of volatiles during cooling, and comprise from zero to $30 \%$ bulk porosity. 
Finally, cooling fractures occur in the welded and partially welded units, especially the relativeiy nonlithophysal zones. The available data suggest that all tuff units at Yucca Mountain contain tectonic fractures. The porous nonwelded units generally contain far fewer such fractures.

The caprock at Yucca Mountain consists of about $140 \mathrm{~m}$ of welded tuff known as the Tiva Canyon Member of the Paintbrush Tuff, with prevalent cooling fractures and lithophysae. Canyons on the eastern flank of Yucca Mountain are infilled with a few meters of alluvium; the minimum thickness of Tiva Canyon under these canyons is several tens of meters. Immediately underlying is a sequence referred to as the nonwelded beds of the Paintbrush Tuff, consisting of individual ash flow and ash fall units totaling roughly $30 \mathrm{~m}$, but varying significantly in thickness and continuity of constituent beds within the site area. The porosity of these nonwelded tuffs is at least $30 \%$, and the saturated matrix conductivity is several orders greater than welded tuff. Underlying these beds is the Topopah Spring Member of the Paintbrush Tuff, consisting of about $300 \mathrm{~m}$ of welded tuff. This unit may be further segregated into thick zones corresponding to variations in welding, devitrification, lithophysal porosity, and other alteration. The candidate host rock has been identified as a relatively nonlithophysal, densely welded zone near the top of the lower third of the Topopah Spring Member.

Between the candidate repository horizon and the water table is the lower third of the Topopah Spring Member, and the upper part of the nonwelded tuffaceous beds of the Calico Hills (hereinafter called the Calico Hills unit). The lower part of the Topopah Spring Member consists of fractured welded tuff, some partially welded strata, and a basal vitrophyre approximately $10 \mathrm{~m}$ thick. The Calico Hills unit is comprised of several major ash flows and ash falls. The vitric matrix of the Calico Hills has been substantially altered to zeolites in the northern part of the site area, thus changing the rock fabric and the hydrologic properties. Fracturing and faulting in the Calico Hills unit are believed to resemble that observed in the thick, nonwelded tunnel beds of Rainier Mesa on the NTS, which have been explored by extensive tunneling.

A number of welded and nonwelded tuff units lie below the Calico Hills unit in the saturated zone. Extrusive and shallow intrusive volcanic rocks have been encountered in boreholes penetrating the lower part of the tuff section. Below the tuffs is a few hundred meters of older, poorly known volcanic rocks and sediments of volcanic and other origin. The tuffs and sediments ir. this lower part of the section are generally more altered than overlying units, and contain secondary clay, zeolites, and carbonate minerals. Underlying this are Paleozoic carbonates, which have been mapped throughout the region.

Yucca Mountain is an upland area mostly surrounded by deep, downfaulted, allwial filled basins. North-south normal faults transect Yucca Mountain and have given rise to gentle $\left(6\right.$ to $\left.10^{\circ}\right)$ eastward dip throughout most of the site area. The repository horizon follows the tilted stratigraphy, meaning that the repository height above the water table and the intervening stratigraphy vary significantly. Tuff units at the site, particularly those comprising the unsaturated zone, exhibit lateral variability corresponding to the inferred distances to the eruptive centers for the units. Thus at Busted Butte situated southeast of the site, the nonwelded beds of the Paintbrush 
Thiff and the Calico Hills unit are substantially thinner than to the north. Also, the Iopopah Spring Member is generally thinner and less densely welded.

Alternative conceptual models have been developec to describe and explain the structural setting of Yucca Mountain, as presented in SCP Section 8.3.1.8 (Tables 8.3.1.8-7 and -8) and Section 8.3.1.17 (Tables 8.3.1.17-7 and -8). These models pertain to such topics and features as the significance of Crater Flat, the subsurface geometry of faults, and the presence of a detachment below Yucca Mountain. One of the major applications of geophysical methods in site characterization will be to further elucidate these features in the subsurface. 


\subsection{PAST GEOPHYSICAL ACTIVITIES}

This section reviews past and ongoing geophysical activities performed for the Yucca Mountain Project, or performed in the vicinity of the Yucca Mountain site. As stated in Section 1.0, only the location, methodology, and applicability of past activities are discussed. The reader is referred to tue various cited references for presentation of geophysical data. The scope of this section is limited as discussed in sortion 1.0, and notably does not include teleseismic ground motion characterization (but does include teleseismic tomography), heat flow studies, or stress measurements.

\subsection{GRAVITY INVESTIGATIONS}

\section{OBJECTIVES}

Gravity investigations were begun at Yucca Mountain in about 1978 to characterize the general geologic and tectonic setting of the area. Gravity studies are particularly useful for (1) characterizing the general configuration of the regional pre-Cenozoic basement, (2) detecting concealed or unrecognized faults, (3) estimating the offset or extent of known faults, and (4) detecting and characterizing igneous features such as calderas and plutons. Gravity methods can detect shallow as well as deep features that juxtapose rocks of significantly different densities. With appropriate horizontal and vertical controls, gravity data also can reveal undulaticns of the base of the crust, which occur at a depth of approximately $33 \mathrm{~km}$ beneath Yucca Mountain.

\section{DATA COVERAGE AND QUAITYY (Gravity measurements)}

Figure 2.1-1 shows the location and distribution of all gravity measurements from available da:a sources located within the area described in Chapter 1.0. About 33,000 gravity measurements have been made in this area, and all have been adjusted to a common gravity datum and recompiled. The accuracies of the gravity measurements themselves are generally $0.1 \mathrm{mgal}$, but Bouguer and residual anomalies derived from these measurements are less accurate, particularly in mountainous terrain where terrain corrections are required. Anomalies calculated from the data in Figure 2.1-1 generally have an uncertainty of about $0.5 \mathrm{mgal}$. Regional gravity anomalies are generally in the range of 5 to $50 \mathrm{mgal}$ (see, for example, Hildenbrand et al., 1988, Figure 2.11), so calculated anomalies are sufficiently accurate for regicnal studies. Figure 2.1-2 shows the same information at about twelve times enlargement for the Yucca Mountain site area and vicinity. Gravity maps based on these data have been compiled for a number of areas at various scales (Table 2.1-1). The principal facts of all the data have been released on magnetic tape for Nevada (Saltus, 1988c) and California (Snyder et al. 1981). 
Table 2.1-1. Regional Gravity Maps of Various Areas within the Regional Study Area (Figure 2.1-1)

\begin{tabular}{|c|c|c|}
\hline Description & Scale & Reference \\
\hline $\begin{array}{l}\text { Bouguer and residual gravity map of } \\
\text { Southern Great Basin }\end{array}$ & $1: 2,500,000$ & $\begin{array}{l}\text { Hildenbrand et al.' } \\
\text { 1988, Fig. } 2.8 \& 2.11\end{array}$ \\
\hline Bouguer gravity map of lievada & $1: 750,000$ & Saltus, $1988 \mathrm{a}$ \\
\hline Bouguer gravity rap of California & $1: 750,000$ & Oliver et al., 1980 \\
\hline Residual gravity map of California & $1: 750,000$ & $\begin{array}{l}\text { Roberts et al., } \\
1981\end{array}$ \\
\hline Residual gravity map of Nevada & $1: 1,000,000$ & Saltus, $1988 \mathrm{~b}$ \\
\hline $\begin{array}{l}\text { Bouguer gravity map of Death valley } \\
\text { Sheet }\end{array}$ & $1: 250,000$ & Healey et al., $1980 \mathrm{~b}$ \\
\hline Bouguer gravity map of Goldfield & $1: 250,000$ & Healey et al., 1980a \\
\hline Bouguer gravity map of Caliente sheet & $1: 250,000$ & Healey et al., 1981 \\
\hline $\begin{array}{l}\text { Bouguer gravity map of Las vegas } \\
\text { Sheet }\end{array}$ & $1: 250,000$ & Kane et al., 1979 \\
\hline Complete Bouguer gravity map of NTS & $1: 100,000$ & Healey et al., $1988 \mathrm{c}$ \\
\hline Isostatic residual gravity map of NTS & $1: 100,000$ & Ponce et al., 1988 \\
\hline $\begin{array}{l}\text { Residual gravity map of Yucca Mt. } \\
\text { and vicinit.y }\end{array}$ & $1: 48,000$ & Snyder \& Carr, 1982 \\
\hline
\end{tabular}




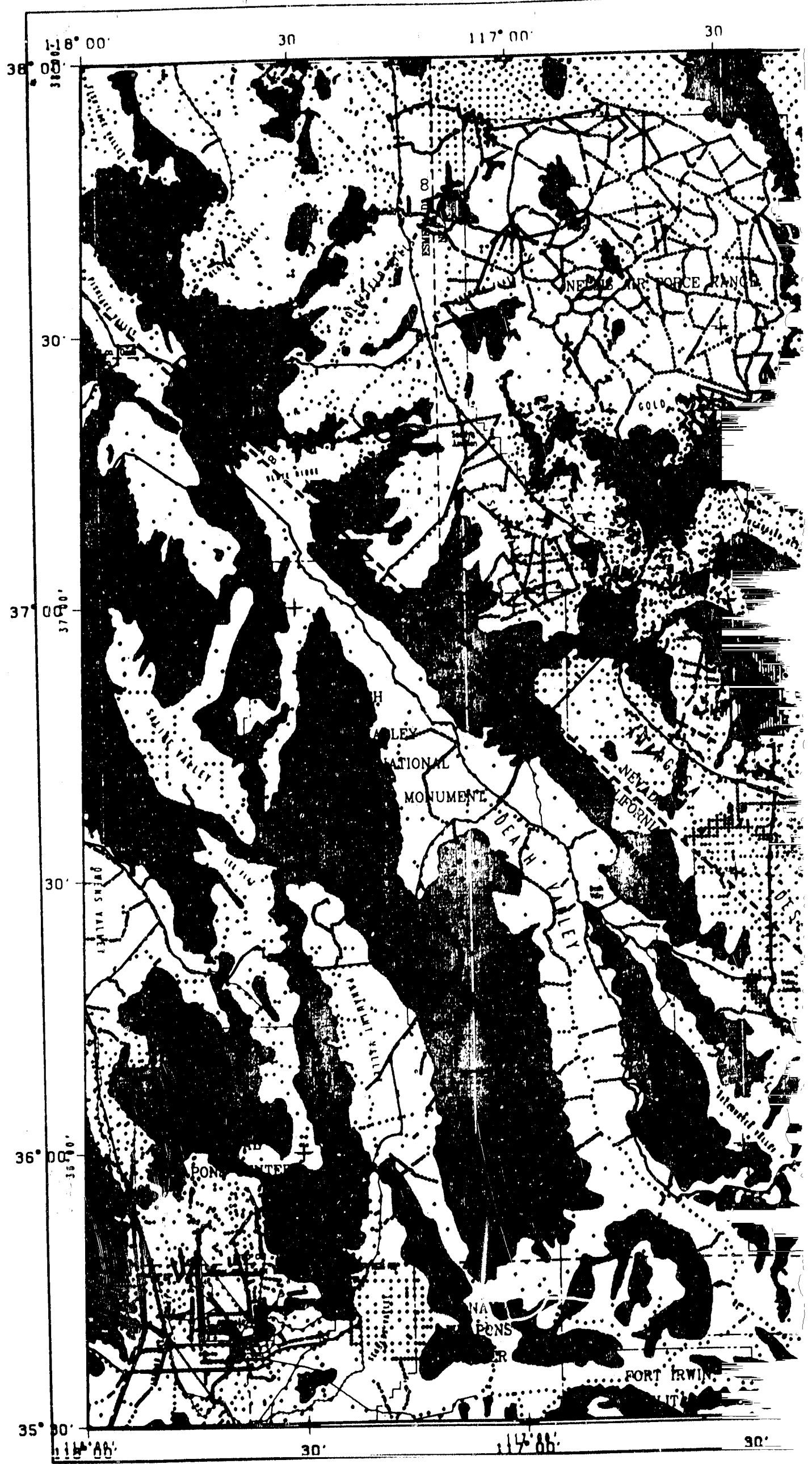




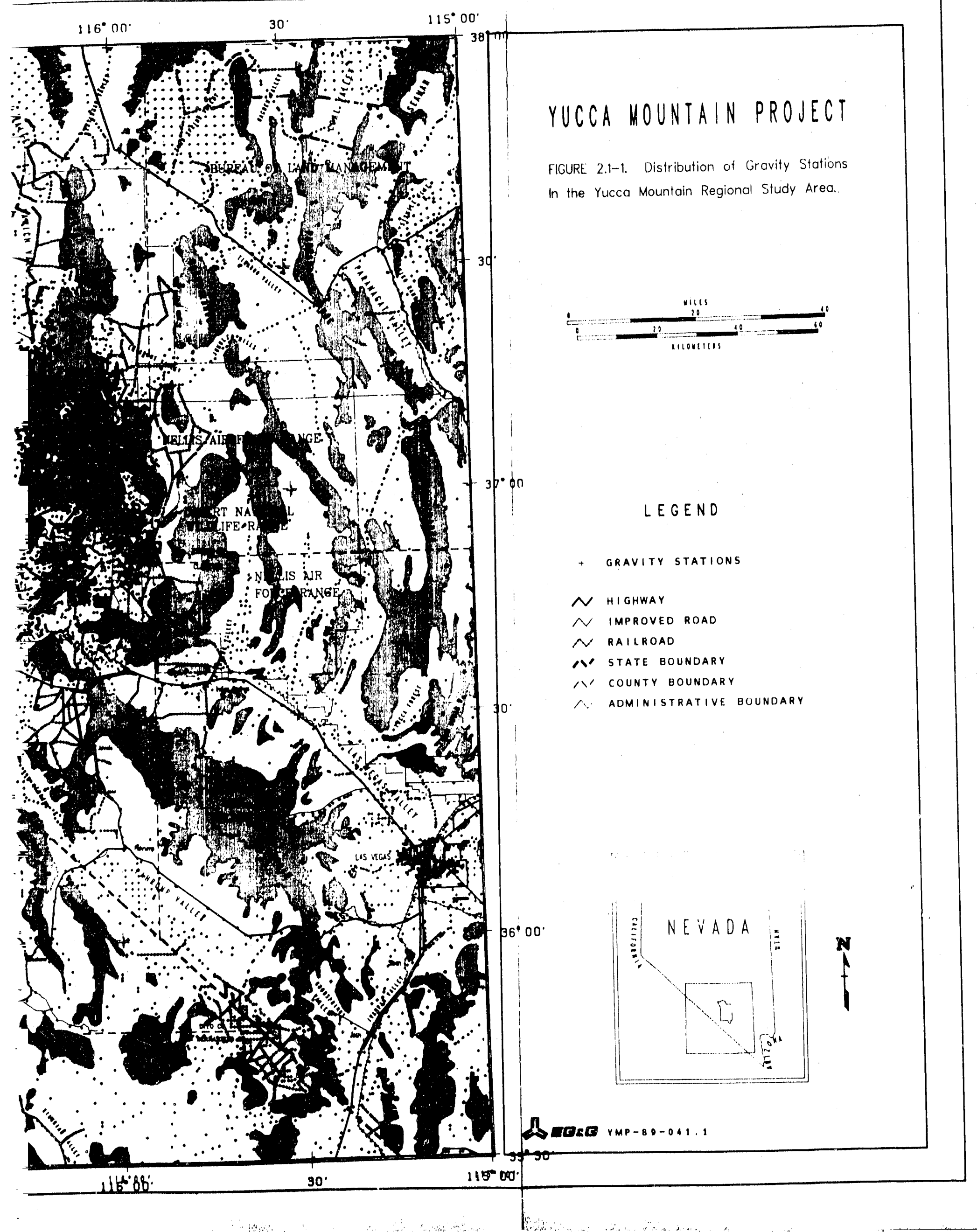



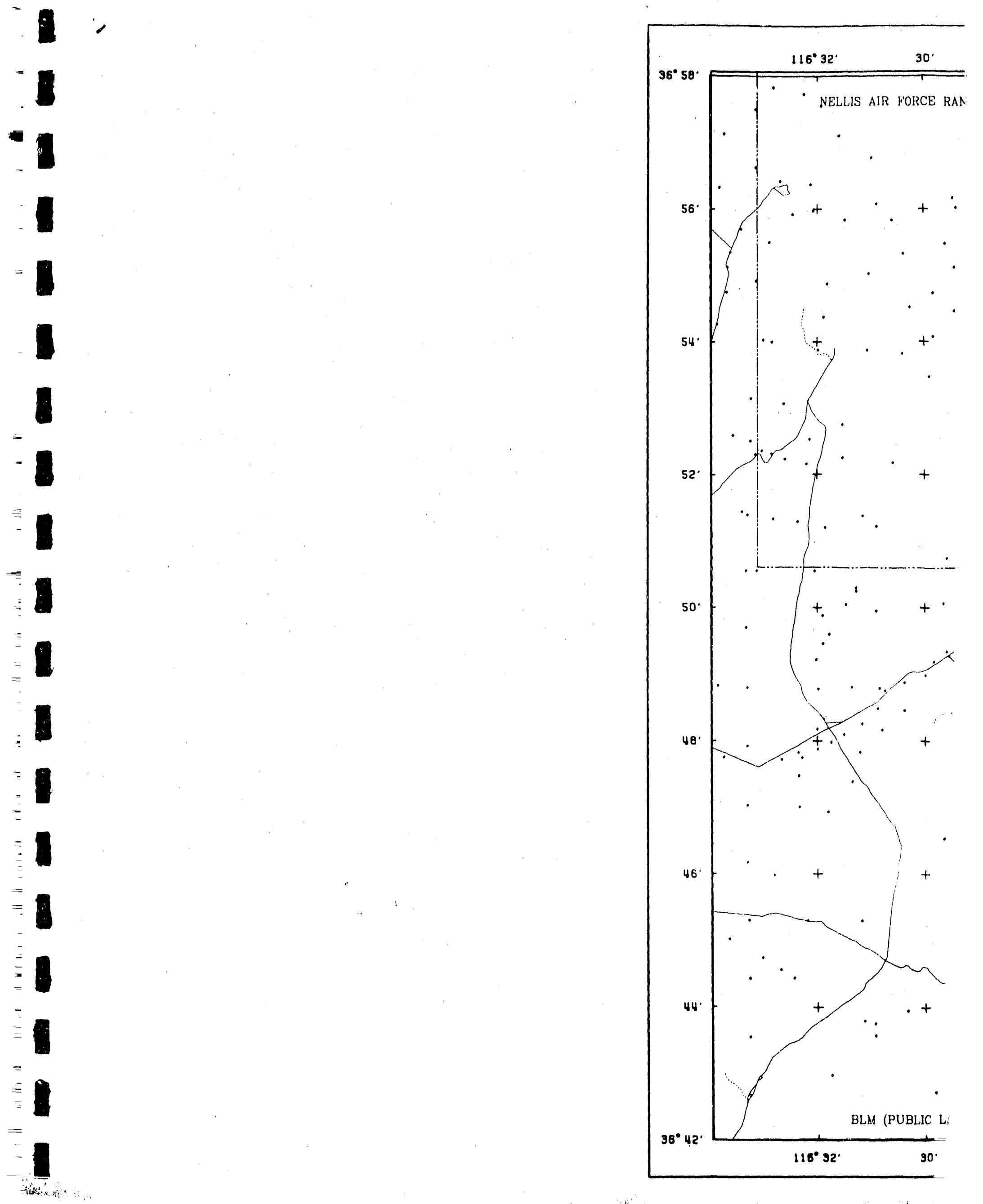


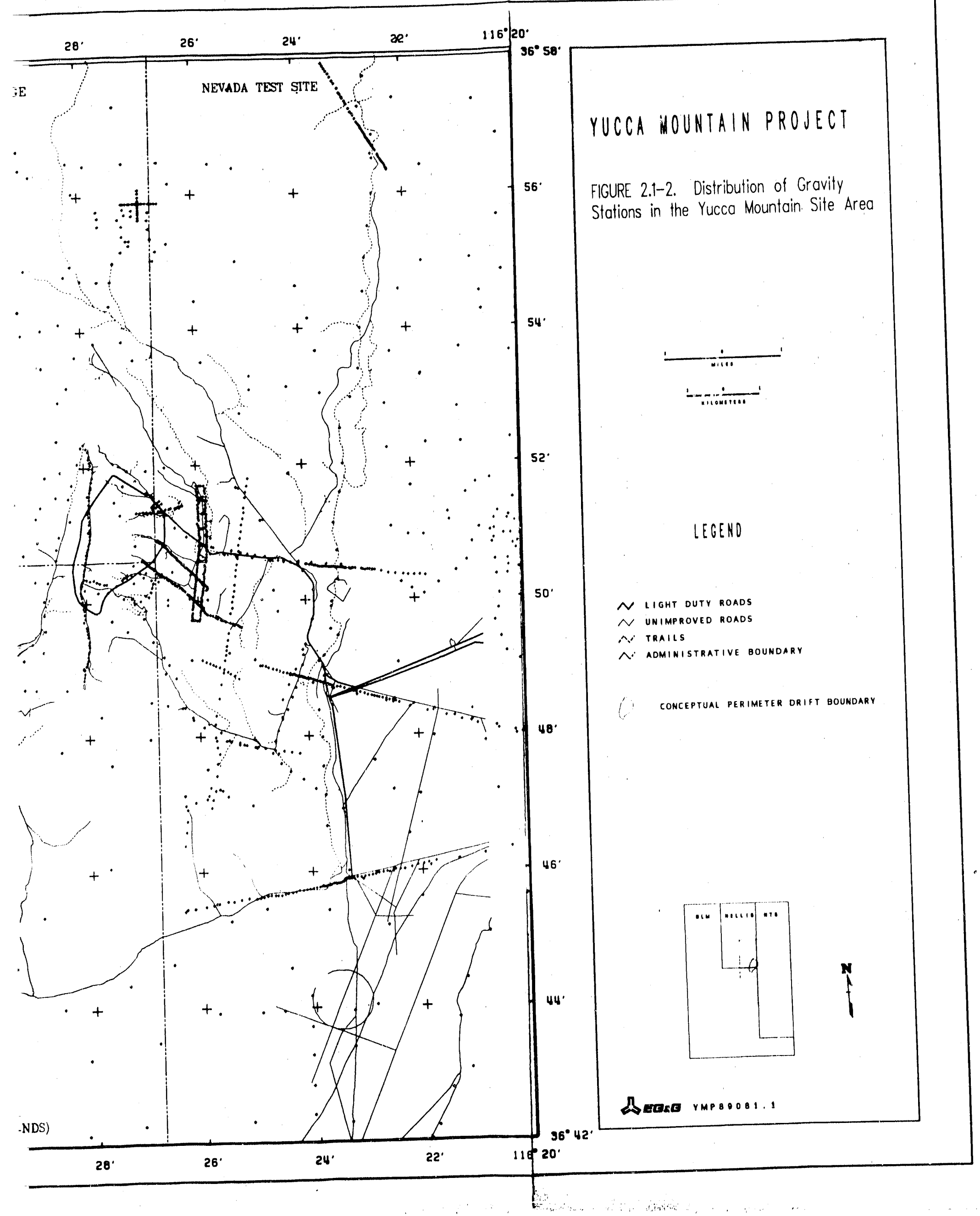


DATA COVERAGE AND QUALITY (Density data)

Rock densities at the NTS and vicinity can be separated into three major groups: pre-Cenozoic sedimentary rocks and intrusive rocks with an average density of about $2.67 \mathrm{gm} / \mathrm{cc}$, Cenozoic volcanic rocks with a density of about $2.4 \mathrm{gm} / \mathrm{cc}$, and nonwelded and partially welded ash-Elow tuffs and alluvium with a density of about $2.0 \mathrm{gm} / \mathrm{cc}$. There are three primary sources of rock density information from the NTS and vicinity: rock samples (including core samples), borehole gravity meter surveys, and borehole density logs. Table 2.1-2 lists in stratigraphic sequence the geologic units in the Yucca Mountain area that are important for gravity interpretation. This table also gives a range of thickness and representative values for density of each unit, and provides a reference for geologic unit names used in the following discussion.

\section{SUMMARY OF RESULTS}

Many regional subsurface geologic structures at the NTS and vicinity were initially identified by the gravity method. A notable result was the prediction of the depth to pre-Cenozoic basement rocks at the location of drillhole UE25 p\#1, about $5 \mathrm{~km}$ north of Busted Butte (Figure 2.1-2). Snyder and Carr (1982, p. 27) used gravity modeling to estimate the depth to Paleozoic basement to be about $3,500 \mathrm{ft}$ at Busted Butte and about 4,750 ft at the nearby gravity saddle (" $s$ " in Figure 2.1-2). On this basis, the depth to basement at $\mathrm{p \# I}$ was estimated to be 4,000 ft. Drilling revealed dolomitic basement at a depth of 4,080 ft (Carr et al., 1986, p. 17). A threedimensional gravity model suggests that pre-Cenozoic basement increases in depth westward directly under the conceptual repository location and reaches 10,000 ft under Crater Flat (Snyder and Carr, 1984). This basement model is apparently consistent with recent seismic refraction data, but has not been tested by drilling. Drillhole UE25 p\#1 (Figure 2.1-2) is the only hole in the Yucca Mountain area to reach basement; the deepest drillholes in the Yucca Mountain-Crater Flat area other than $p \# 1$ are $6,000 \mathrm{ft}$ deep and bottom in Miocene volcanic rocks.

Gravity methods also helped to identify the silent Canyon caldera underlying Pahute Mesa to the north of the site area, where gravity data indicate a volcanic section at least $16,000 \mathrm{ft}$ thick (Healey, 1968, p. 153). Drilling to $13,686 \mathrm{ft}$ within the gravity anomaly, and surface mapping (Byers et al., 1976) have since confirmed the gravity model. Similarly, Kane et al. (1981) interpreted gravity data from the Timber Mountain area and determined that (1) a broad gravity high over the southeast side of Timber Mountain is associated with exposed Miocene intrusive rocks and suggests that this part of the caldera is underlain by such rocks, an important conclusion if the Timber Mountain area were to be considered for radioactive waste storage; and (2) the Timber Mountain caldera truncates the southern edge of the older Silent Canyon caldera.

Another useful application of gravity methods is in measuring vertical movement of subsurface density layers associated with major earthquakes (Oliver et al., 1975). Initial absolute and high-precision measurements were recently made in the Yucca Mountain site area for this application and 
Table 2.1-2. Density and Thickness of Selected Geologic Units in the Yucca Mountain Area (after Snyder and Carr, 1984)

\begin{tabular}{|c|c|c|c|}
\hline Age & Unit & $\begin{array}{l}\text { Approx. } \\
\text { Thickness } \\
\text { (M) }\end{array}$ & $\begin{array}{l}\text { Average } \\
\text { Density } \\
(g m / c c)\end{array}$ \\
\hline $\begin{array}{l}\text { Quaternary \& } \\
\text { Tertiary }\end{array}$ & $\begin{array}{l}\text { alluvium } \\
\text { basalt }\end{array}$ & $\begin{array}{l}0-300 \\
0-200\end{array}$ & $1.6-2.0$ \\
\hline Tertiary & Timber Mountain Tuff & & \\
\hline $11.3 \mathrm{Ma} *$ & $\begin{array}{l}\text { Ammonia Tanks Mbr \& } \\
\text { Rainier Mesa Mbr, } \\
\text { undivided } \\
\text { Paintbrush Tuff }\end{array}$ & $0-150$ & 1.9 \\
\hline $12.6 \mathrm{Ma}^{\star}$ & $\begin{array}{l}\text { Tiva Canyon Mbr } \\
\text { Yucca Mountain Mbr } \\
\text { Pah Canvon Mor }\end{array}$ & $\begin{array}{r}120 \\
0-60 \\
0-70\end{array}$ & $\begin{array}{l}2.1 \\
1.9\end{array}$ \\
\hline $13.1 \mathrm{Ma} *$ & $\begin{array}{l}\text { Pan Canyon Mor } \\
\text { Topopah Spring Mbr }\end{array}$ & 300 & $\begin{array}{l}1.9 \\
2.2\end{array}$ \\
\hline $13.4 \mathrm{Ma}$ * & $\begin{array}{l}\text { Rhyolite lavas and tuff } \\
\text { of Calico Hills } \\
\text { Crater Flat Tuff }\end{array}$ & $10-200$ & 1. 9 \\
\hline $14.0 \mathrm{Ma} *$ & $\begin{array}{l}\text { Prow Pass Mbr } \\
\text { Bullfrog Mbr } \\
\text { Tram Mbr } \\
\text { Rhyodacite lavas } \\
\text { Lithic Ridge Tuff } \\
\text { Ash flow and bedded tuff }\end{array}$ & $\begin{array}{r}100 \\
150 \\
300 \\
0-200 \\
300 \\
300+\end{array}$ & $\begin{array}{l}2.1 \\
2.1 \\
2.25 \\
2.35 \\
2.35 \\
2.45\end{array}$ \\
\hline Late Paleozoic & $\begin{array}{l}\text { limestone \& argillite } \\
\text { units }\end{array}$ & 2000 & 2.62 \\
\hline $\begin{array}{l}\text { Middle and early } \\
\text { Paleozoic }\end{array}$ & $\begin{array}{l}\text { various limestone, } \\
\text { dolomite, quartzite, \& } \\
\text { other sedimentary units }\end{array}$ & 4000 & 2.72 \\
\hline $\begin{array}{l}\text { Early Paleozoic \& } \\
\text { Precambrian }\end{array}$ & $\begin{array}{l}\text { quartzite, and other } \\
\text { sedimentary units }\end{array}$ & $3500+$ & 2.65 \\
\hline
\end{tabular}

* Radiometric ages from Marvin et al. (1970).

calibration purposes (Zumberge et al., 1988; Harris and Ponce, 1988), and future remeasurements should be able to detect changes of less than $5 \mathrm{~cm}$ in the absolute elevation of measurement points.

Gravity surveys are also useful for inexpensive study of tectonic structures, particularly those which offset the basement or cause variations in the depth to basement. However, the interpretation of gravity alone does not produce unique models of the subsurface. It is therefore important that gravity data be collected along traverses and analyzed with other geophysical measurements including seismic reflection and refraction, magnetic, and geoelectric data. It is also important to obtain density data from surface 
measurements, gamma-garma logs, and gravity meter borehole measurements to constrain gravity models.

\section{BIBLIOGRAPHY FOR SECTION 2.1}

Byers, F.M., Jr., W.J. Carr, P.P. Orkild, W.D. Quinlivan, and K.A. Sargent, 1976. Volcanic Suites and Related Cauldrons of Timber Mountain-Oasis Valley Caldera Complex, Southern Nevada, U.S. Geological itrvey Professional Paper 919, $70 \mathrm{p}$.

Carr, M.D., S.J. Waddell, G.S. Vick, J.M. Stock, S.A. Monsen, A.G. Harris, B.W. Cork, and F.M. Byers, 1986. Geology of Drillhole UE25p\#1: A Test Hole into Pre-Tertiary Rocks Near Yucca Mountain, Southern Nevada, U.S. Geological Survey Open File Report 86-175, 87 p.

Harris, R.N., and D.A. Ponce, 1988. High-Precision Gravity Network to Monitor Temporal Variations in Gravity Across Yucca Mountain, Nevada, U.S. Geological Survey Open File Report 88-243, 19 p. (in press).

Harris, R.N., D.I. Healey, D.A. Ponce, and H.W. Oliver, _. Principal facts for 15,355 Gravity Stations in the Nevada Test site and Vicinity.

Healey, D.I., 1968. "Applicatior of Gravity Data to Geologic Problems at the Nevada Test Site," in Eckel, E.B. (ed.), Nevada Test Site, Geological Society of America Memoir 110, p. 147-156.

Healey, D.I., 1970. "Calculated In Situ Bulk Densities from Subsurface Gravity Observations and Density Logs, Nevada Test Site and Hot Creek Valley, Nye County, Nevada," in Geological Survey Research, U.S. Geological Survey Professional Paper 700 B, P. B52-B62.

Healey, D.I., 1983. "Gravity Investigations," in Geologic and Geophysical Investigations of Climax Stock Intrusive, Nevada, U.S. Geological Survey Open File Report 83-377, 76 p.

Healey, D.L., 1986. Borehole Gravity Meter Survey in Drillhole USW G-4, Yucca Mountain Al a, Nye County, Nevada, U.S. Geological Survey Open File Report 86-205, $18 \mathrm{p}$.

Healey, D.I., F.G. Clustom, and D.A. Glover, 1984. Burehole Gravity Meter Surveys in Drillholes USW G-3, UE-25p\#1, Yucca Mountain Area, Nevada, U.S. Geological Survey Open File Report 84-672, 16 p.

Healey, D.L., R.N. Harris, D.A. Ponce, and H.W. Oliver, 1988C. Complete Bouguer Gravity Map of the Nevada Test Site and Vicinity, U.S. Ceological Survey Open File Report 87-506, scale 1:100,000.

Healey, D.I., D.B. Snyder, R.R. Wahl, and F.E. Currey, 1981. "Bouguer Gravity Map of Nevada, Caliente Sheet," Nevada Bureau of Mines and Geology Map 70, scale 1:250,000. 
Healey, D.I., R.R. Wahl, and F.E. Currey, 1980a. "Bouguer Gravity Map of Nevada, Goldfield and Mariposa Sheets," Nevada Bureau of Mines and Geology Map 68, scale 1:250,000.

Healey, D.L., R.R. Wahl, and H.W. Oliver, 1980b. "Bouguer Gravity Map of Nevada, Death Valley Sheet," Nevada Bureau of Mines and Geology Map 69, scale $1: 250,000$.

Hildenbrand, T.G., A.M. Rogers, H.W. Oliver, S.C. Harmsen, J.K. Nakata, D.S. Aitken, R.N. Harris, and M.D. Carr, 1988. "Regional Geologic and Geophysical Maps of Southern Great Basin," in M.D. Carr and J.C. Yount (eds.), Geologic and Hydrologic Investigations of a Potential Nuclear Waste Disposal Site at Yucca Mountain, Southern Nevada, U.S. Geological Eurvey Bulletin 1790, p. 3-21.

Izett, G.A., 1960. "Granite" Exploration Hole, Area 15, Nevada Test Site, Nye County, Nevada - Interim report, Part C, Physical Properties, U.S. Geological Survey Open File Report TEM-836-c, $36 \mathrm{p}$.

Jansma, P.E., D.B. Snyder, and D.A. Ponce, 1982. principal Facts of Gravity Stations with Gravity and Magnetic Profiles from the Southwest Nevada Test Site, Nye County, Nevada, as of January 1982, U.S. Geological Survey Open File Report 82-1041.

Johnson, R.B., and I.R. Ege, 1964. Geology of the Pluto Site, Area 401, Nevada Test Site, Nye County, Nevada, U.S. Geological Survey Trace Elements Investigations Report TEI-841, $127 \mathrm{p}$.

Kane, M.F., D.L. Healey, D.I. Peterson, H.E. Kaufmann, and D. Reidy, 1979. "Bouguer Gravity Map of Nevada, Las Vegas Sheet," Nevada Bureau of Mines and Geology Map 61, scale 1:250,000.

Kane, M.F., M.W. Webring, and B.K. Bhattacharyya, 1981. A Preliminary Analysis of Gravity and Aeromagnetic Surveys of the Timber Mountain Area, Southern Nevada, U.S. Geological Survey Open File Report 81-189, 40 p.

Keller, G.V., 1957. "Porosity, Density, and Fluid Permeability or the Oak Spring Formation," in Diment, $W . H$. et al., Properties of the Oak Spring Formation in Area 12 at the Nevada Test Site, U.S. Geological Survey Trace Elements Investigations Report TEI-672.

Marvin, R.F., F.M. Byers, Jr., H.H. Mehnert, P.P. Orkild, and T.W. Stern, 1970. "Radiometric Ages and Stratigraphic Sequence of Volcanic and Plutonic Rocks, Southern Nye and Western Lincoln Counties, Nevada," Geological Society of America Bulletin, vol. 81, p. 2657-2676.

Morelli, C. (ed.), 1974. The International Gravity Standardization Net 1971, International Association Geodesy Special Publ., no. 4, 194 p.

Oliver, H.W., R.H. Chapman, S. Biehler, A. Griscom, E.A. Silver, L.A. Beyer, and S.I. Robbins, 1980. "Gravity Map of California and Its Continental Margin," California Division of Mines and Geology Special Map, scale $1: 750,000$. 
Oliver, H.W., S.I. Robbins, R.B. Grannell, R.W. Alewine, and S. Biehler, 1975. "Surface and Subsurface ilovements Determined by Remeasuring Gravity," in G.B. Oakshott (ed.), San Fernando Earthquake of February 9, 1971, California Division of Mines and Geology Bulletin 196, p. 195-211.

Ponce, D.A., 1981. Preliminary Gravity Investigations of the Wahmonie Site, Nevada Test Site, Nye County, Nevada, JJ.S. Geological Survey Open File Report 81-522, $64 \mathrm{p}$.

Ponce, D.A., R.N. Harris, and H.W. Oliver, 1988. Isostatic Gravity Map of the Nevada Test Site and Vicinity, Nevada, U.S. Geological Survey Open File Report 88-664, scale 1:100,000 (in press).

Roberts, C.W., R.C. Jachens, and H.W. Oliver, 1981. Isostatic Residual Gravity Map of California, U.S. Geological Survey Open File Report 81-573, scale 1:750,000.

Saltus, R.W., 1988a. "Bouguer Gravity Anomaly Map of Nevada," Nevada Bureau of Mines and Geology Map 94A, scale 1:750,000.

Saltus, R.W., 1988b. "Regional Residual and Derivative Gravity Maps of Nevada," Nevada Bureau of Mines and Geology Map 94B, four at scale $1: 1,000,000$ and two at scale $1: 2,000,000$.

Saltus, R.W., 1988c. Gravity Data for the State of Nevada on Magnetic Tape, U.S. Geological Survey Open File Report 88-433, 20 p.

Snyder, D.B., and W.J. Carr, 1982. Preliminary Results of Gravity Investigations at Yucca Mountain and Vicinity, Southern Nye County, Nevada, U.S. Geological Survey Open File Report 82-701, 36 p.

Snyder, D.B. and W.J. Carr, 1984. "Interpretation of Gravity Data in a Complex Volcano-Tectonic Setting, Southwestern Nevada," Journal of Geophysical Research, vol. 89, no. Bl2, p. 10,193-10,206.

Snyder, D.B., C.W. Roberts, R.W. Saltus, and R.F. Sikora, 1981. Magnetic Tape Containing the Principal Facts of 64,402 Gravity Stations in the State of California, U.S. Geological Survey Report, 30 p.; available from National Technical Information Service, U.S. Department of Commerce, Springfield, VA 22161, NTIS PB-82168287.

Zumberge, M.A., R.N. Harris, H.W. Oliver, G.S. Sasagawa and D.A. Ponce, 1988. Preliminary Results of Absolute and High-Precision Gravity Measurements at the Nevada Test Site and Vicinity, Nevada, U.S. Geological Survey Open File Report 88-242, 29 p. 


\subsection{MAGNETIC AND PALEOMAGNETIC INVESTIGATIONS}

\section{OBJECTIVES}

Aeromagnetic, ground magnetic, paleomagnetic, and magnetic property measurements have been made intermittently at the NTS and vicinity in support of subsurface structural studies, Curie temperature isotherm analysis, correlation of volcanic strata, and studies of structural rotation about a vertical axis. These data are also needed to locate and estimate the volume of buried Quaternary basalts for determining the probability of future eruptions and to locate concealed faults which offset strata within Yucca Mountain (Oliver and Ponce, 1987; DOE, 1988).

\section{DATA COVERAGE AND QUALITY}

Figure 2.2-1 shows the existing coverage of aeromagnetic data within a radius of about $100 \mathrm{~km}$ of Yucca Mountain, and Figure 2.2-2 shows the outlines of the six aeromagnetic surveys listed in Table 2.2-1 which cover various parts of the proposed Yucca Mountain site area and vicinity. (The location of Figure 2.2-2 is shown on Figure 2.2-1 for reference). These index maps indicate the availability of a considerable amount of magnetic data and he? delineate areas where more data are needed. For example, the present coverage of the site area and vicinity to a distance of about $15 \mathrm{~km}$ consists of draped profiles (flown at a constant elevation above terrain) with a

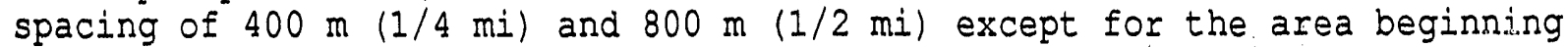
only $5 \mathrm{~km}$ to the northwest of the site area for which only barometric data (flown at a constant elevation above sea level) are available (Figure 2.2-1). The draped data are generally $120 \mathrm{~m}(400 \mathrm{ft}$ ) above ground, whereas the barometric data were flown at a constant elevation of $2,440 \mathrm{~m} \cdot(8,000 \mathrm{ft})$ and are therefore much less detailed because the average elevation of terrain is about 4,000 ft. The Death Valley area southwest of the site area was

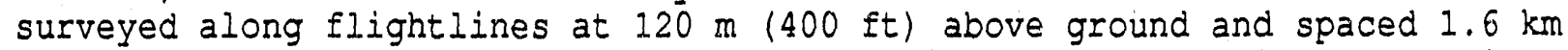
apart. This survey was intended for reconnaissance exploration of uranium under the NURE (National Uranium Resource Evaluation) program (Figure 2.2-2). The flightlines are too far apart for such low-level flights, and this coverage misses about a third of buried magnetic structures; thus, the NURE data are regarded as inadequate for structural studies.

Compilations of regional aeromagnetic data indexed in Figure 2.2-1 have been made at a scale of $1: 2,500,000$ by computer continuation of all data sets to a common surface of $3,800 \mathrm{~m}(12,500 \mathrm{ft}$ ) above sea level (Hildenbrand et al., 1988). A larger scale regional aeromagnetic map was also prepared by continuing these data either downward or upward to a level of $305 \mathrm{~m}(1,000$ ft) above terrain at 1:750,000 (Hildenbrand and Kucks, 1988). Mosaics of original contract data are being assembled at $1: 250,000$ for $1^{\circ}$ by $2^{\circ}$ areas surrounding Yucca Mountain. Those to the east and south are complete (Saltus and Snyder, 1986; Saltus and Ponce, 1988), and those to the west and north are in progress.

Aeromagnetic compilations at 1:100,000-scale are being planned in order to be consistent with four new $1: 1,000,000$-scale $1 / 2^{\circ} \times 1^{\circ}$ topographic maps 
苞

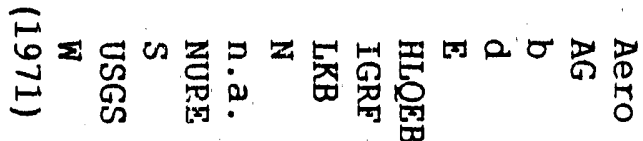

ڤั)

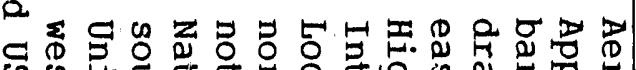

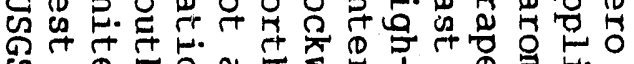

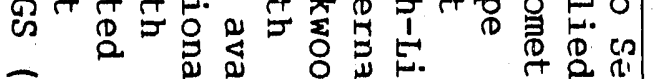

巨

ช$$
\text { 尊 }
$$

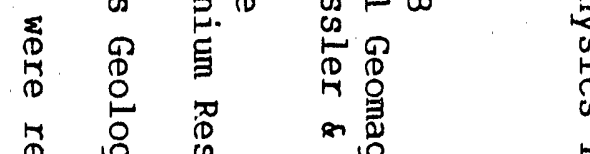$$
\frac{7}{8}
$$

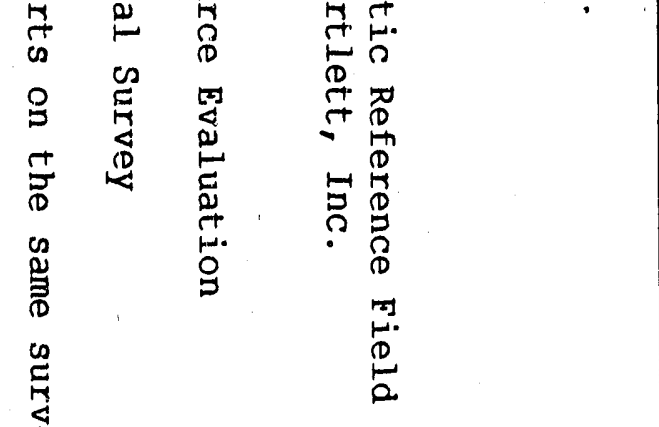

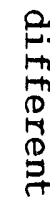

告.

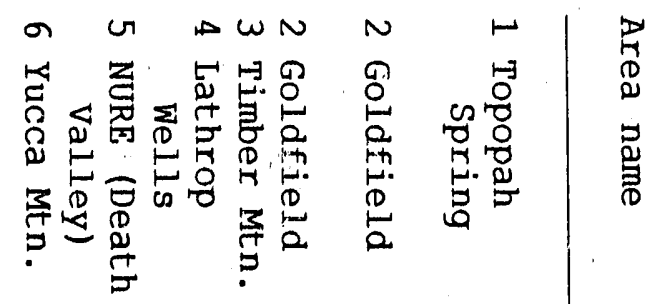

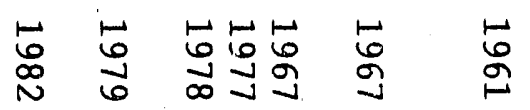

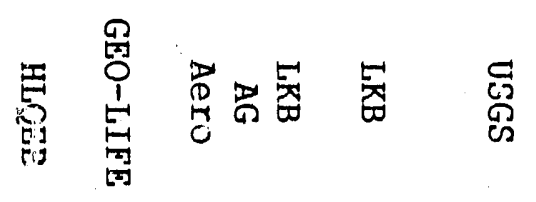

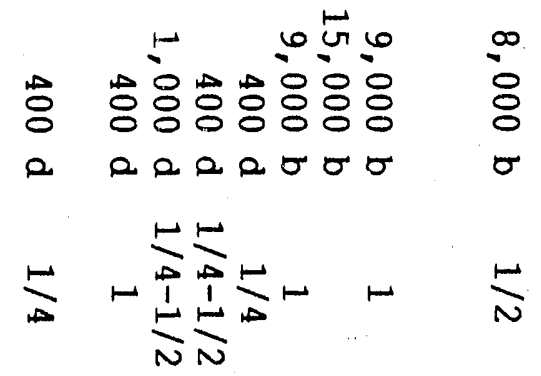

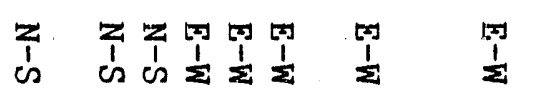

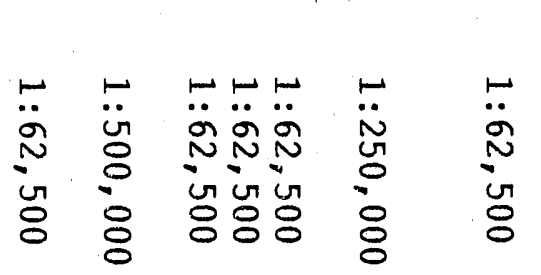

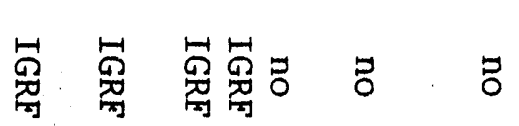

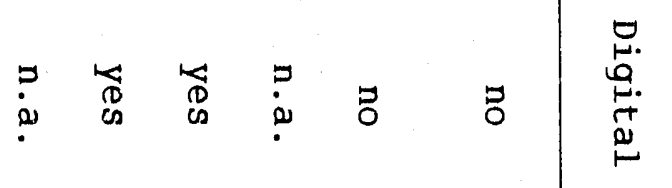

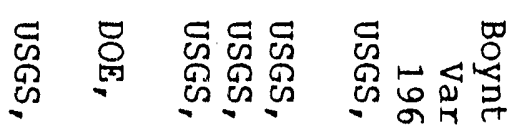

总

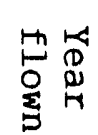

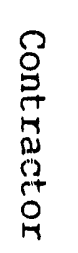

蛋

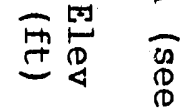

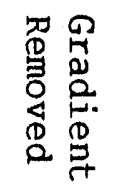

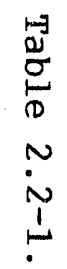

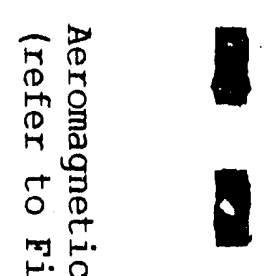

突

N

N赵

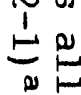

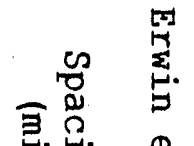

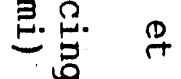

$\stackrel{8}{:}$

\begin{tabular}{ll}
0. & \\
0 & \multirow{6}{0}{} \\
0 & 0 \\
0 & 0
\end{tabular}

ก

ㅇํㅁ

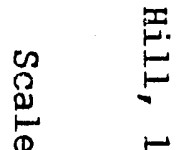

ஸे
0
0

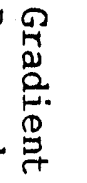

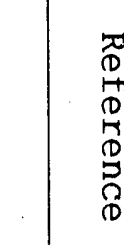

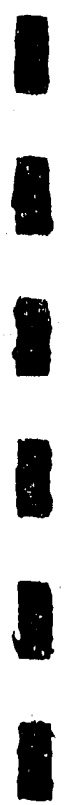

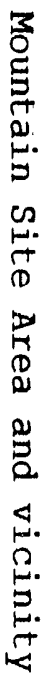




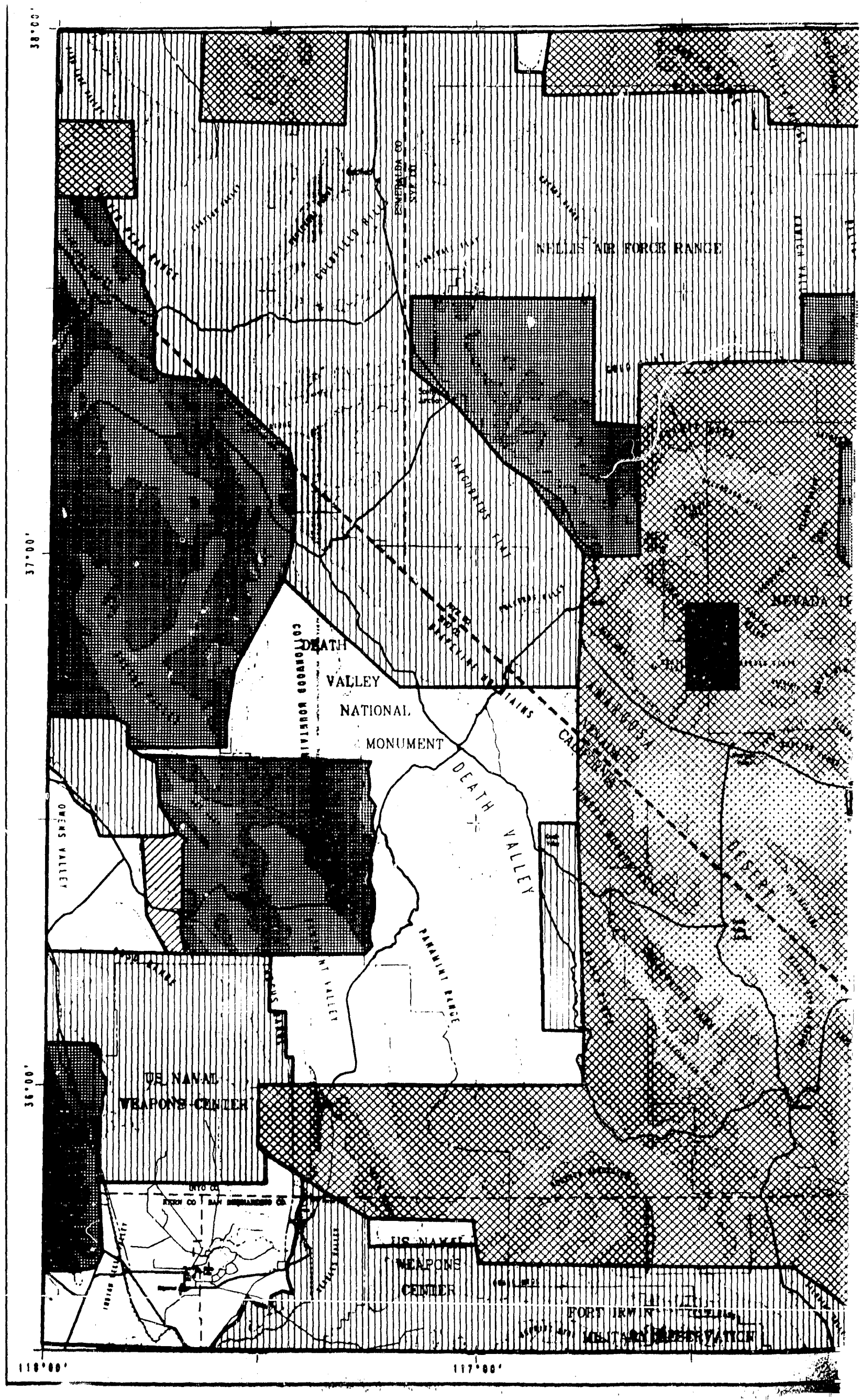




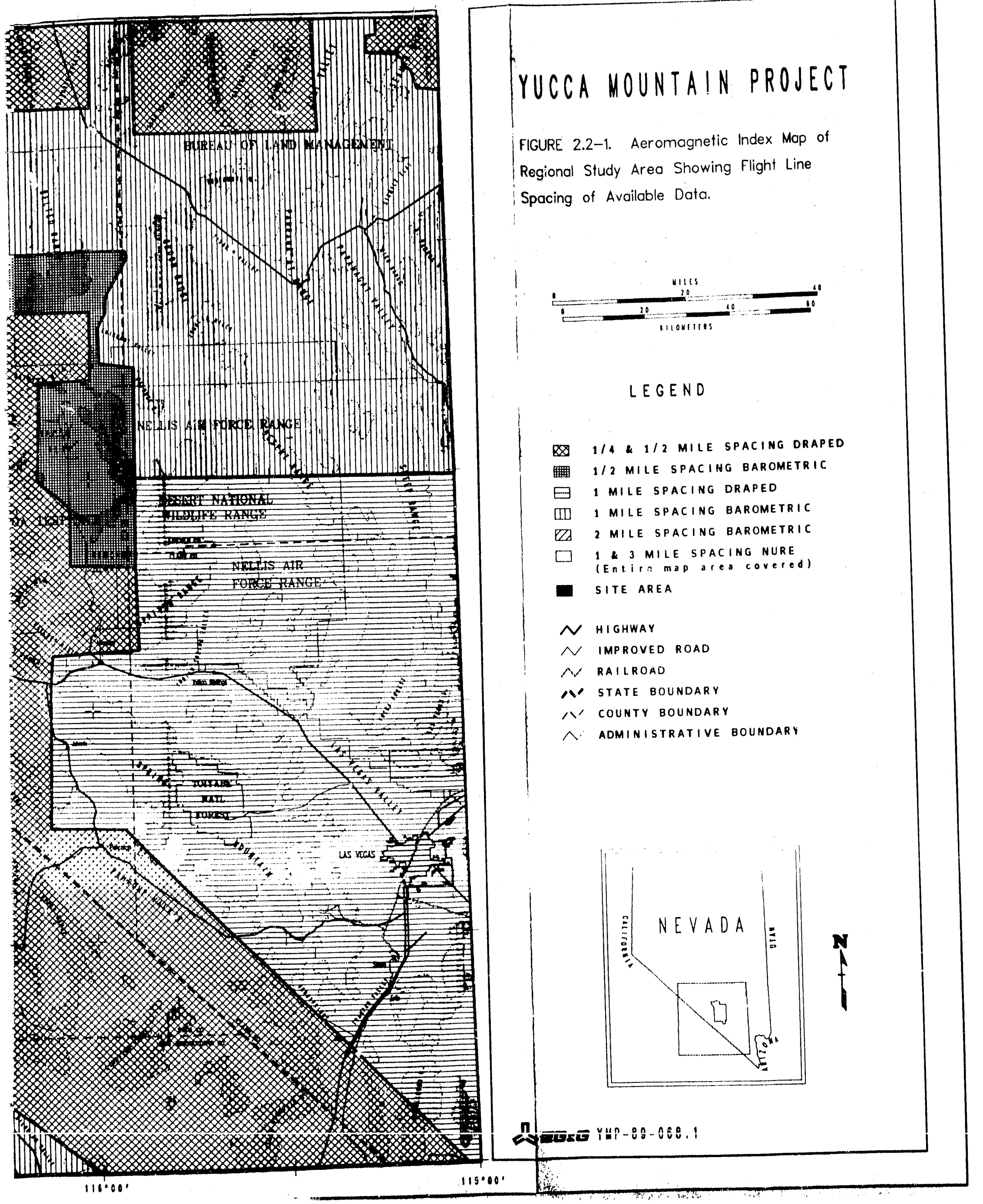




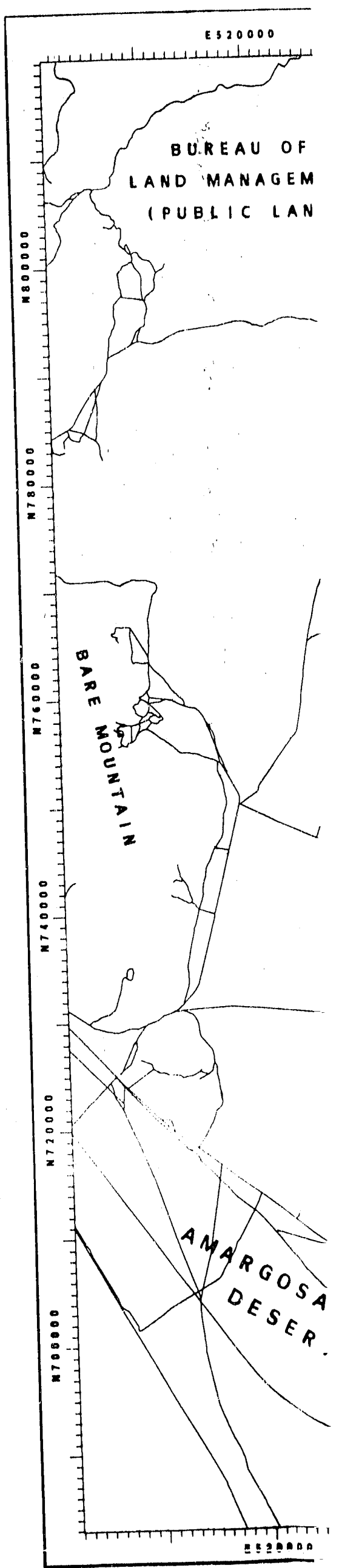




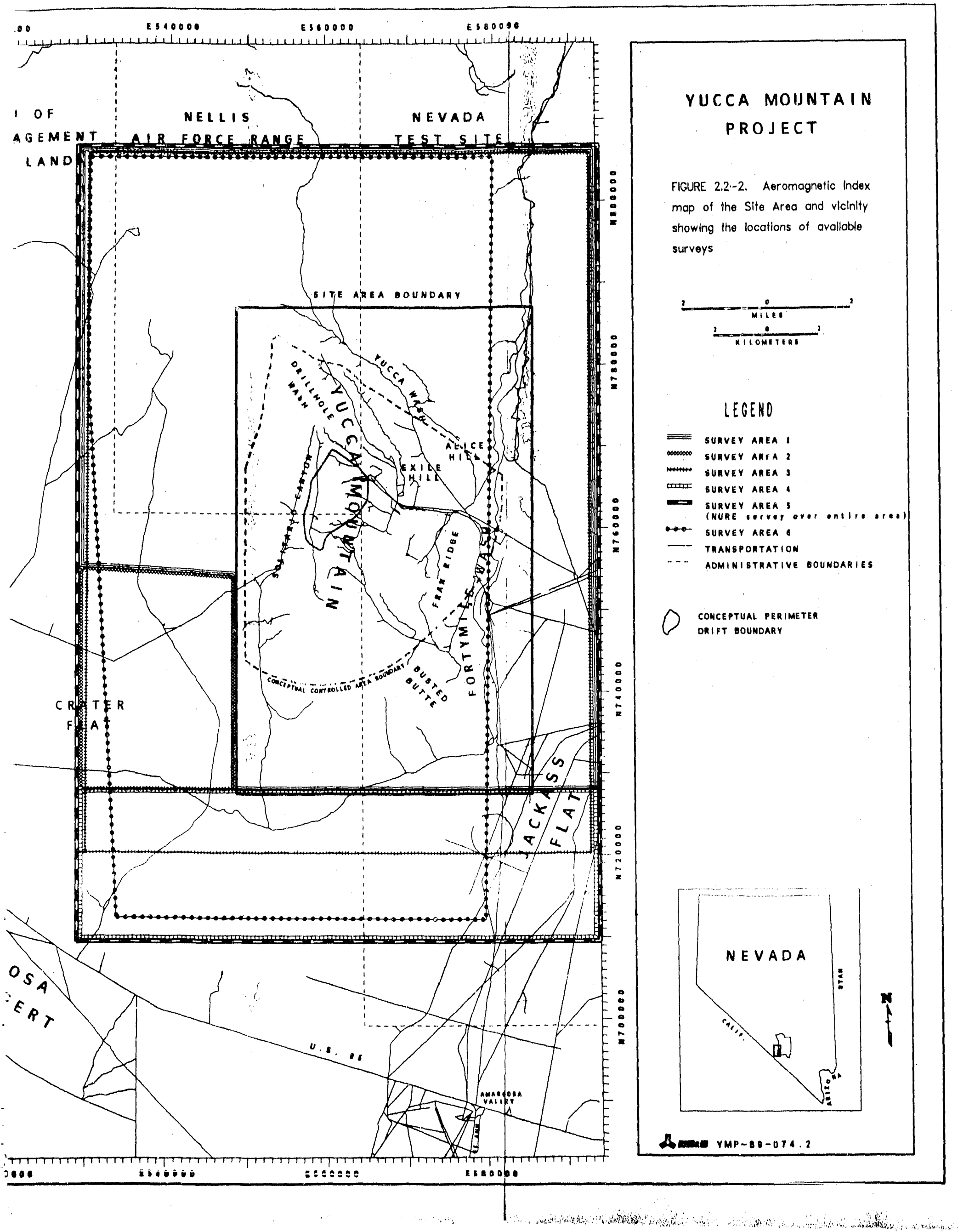


that surround Yucca Mountain. A 20-nT (nanoTesla) contour aeromagnetic map of the site area and vicinity (Figure 2.2-2) is available at 1:48,000 (Kane and Bracken, 1983). For a detailed index and listing of all aeromagnetic surveys in southern Nevada being incorporated into these maps, see Erwin et al. (1980) and Hill (1986).

Ground Magnetic Data

Measurements of total-field magnetic intensity have been made along selected traverses at Yucca Mountain, Lathrop Wells (to the south), and Walumonie/Calico Hills (to the east). Most of the measurements were made on foot with a ground magnetometer read at 3 to $30 \mathrm{~m}$ intervals depending on the horizontal gradient of the magnetic field. Some measurements at Wahmonie and Calico Hills were made with a truck-mounted flux-gate magnetometer (G. Bath, written communication, 1980).

The ground data at Yucca Mountain consist of five $\mathrm{N}-\mathrm{S}$ profiles from one to several $\mathrm{km}$ in length. These data were used along with aeromagneric data to test the feasibility of magnetic methods for locating concealed faults and possible intrusions (Bath and Jahren, 1984; Bath, 1985).

Ground measurements were made near Lathrop Wells in an area apparently underlaj.n by reversely magnetized Quaternary basalts (Kane and Bracken, 1983; Crowe et al., 1986). The measurements consist of $E-W$ and $N-S$ lines through the southern anomalous low of the dipole anomaly at intervals of 1 to $10 \mathrm{~m}$ as needed to define the anomaly.

At Wahmonie and Calico Hills, N-S ground profiles were obtained to better delineate aeromagnetic highs thought to be associated with buried intrusions and magnetite-rich altered argilite, respectively (Ponce, 1984; Snyder and Oliver, 1981).

A.l these ground measurements were made with a Geometrics protonprecession magnetometer, which has a reading accuracy of $1 \mathrm{nT}$. Diurnal corrections were made using continuous magnetic measurements made at a local magnetic base station with Geometrics equipment.

\section{Paleomagretic and Rock Magnetic Studies}

There are three important objactives of the paleomagnetic and rock magnetic studies at Yucca Mountain: (1) to support structural geologic studies by providing paleomagnetic data bearing on vertical-axis rotation; (2) to aid studies of volcanic stratigraphy; and (3) to provide constraints for the modeling of airborne, surface, and borehole magnetic data. In addition, the direction of remanent magnetization of samples from drill core provides a means of obtaining azimuthal orientation of core segments from boreholes at Yucca Mountain (Rosenbaum and Rivers, 1985).

Laboratory measurements of magnetic properties (e.g., remanent magnetization and magnetic susceptibility) have been obtained on numerous samples from surface outcrops and from drill core. In the immediate vicinity of Yucca Mountain, a total of about 65 surface sites have been collected and analyzed from the Crater Flat, Paintbrush, and Timber Mountain tuffs. These sites lie within the area from $36^{\circ} 40^{\prime} \mathrm{N}$ to $36^{\circ} 55^{\prime} \mathrm{N}$ latitude, and from $116^{\circ} 22^{\prime} \mathrm{W}$ 
to $116^{\circ} 35^{\prime} \mathrm{W}$ longitude, roughly corresponding to the designated site area. Data also exist for about 70 sites in the area of Yucca Flat. Most of these sites are within the same geologic strata as those at Yucca Mountain, although some are in older units. In addition, about 25 other paleomagnetic sites from a variety of geologic units exist within the NTS. The directional and susceptibility data from these sites are of high quality. Samples were collected at roughly $3 \mathrm{~m}$ intervals throughout driliholes USW G-1, USW G-2, USW G-3, and USW GU-3, and at somewhat greater intervals from holes $\mathrm{VH}-1$ and VH-2. These samples were oriented with respect to the drill core axis. More closely spaced fully-oriented samples were collected from oriented core runs in these and other holes (e.g., USW H-1, UE25a\#4, a\#5, a\#6, and a\#7).

Directions of remanent magnetization from 30 surface sites show that the region between the north and south ends of Yucca Mountain have undergone about $30^{\circ}$ of vertical-axis rotation since emplacement of the Tiva Canyon Member. Although rotations about a horizontal axis (tilts) are easily recognized visua:ly in many layered rocks, comparison of declinations of remanent magnetization is often the only technique that can provide a measure of rotation about a vertical axis. On a regional scale, relative vertical-axis rotations between sites may be obtained by comparison of paleomagnetic directions from individual volcanic flows or cooling units. Such studies require that (1) individual volcanic units can be unequivocally identified, (2) structural attitudes can be accurately determined, and (3) the volcanic units are reliable paleomagnetic recorders. Geologic mapping and studies of volcanic stratigraphy in the Yucca Mountain area have helped satisfy the first two requirements. Detailed paleomagnetic studies of several ash-flow sheets, using samples from boreholes at Yucca Mountain, have demonstrated that the Tiva Canyon Member of the Paintbrush Tuff, and the Prow Pass and Bullfrog Members of the Crater Flat Tuff are reliable paleomagnetic recorders, but that the Topopah Spring Member of the Paintbrusin Tuff is not (Rosenbauni and Snyder, 1985; Rosenbaum, 1986). Directions of remanent magnetization from numerous surface sites in the three paleomagnetically reliable ash-flow tuff sheets demonstrate about $30^{\circ}$ of vertical-axis rotation between the north and south ends of Yucca Mountain since emplacement of the Tiva Canyon Member (Scott and Rosenbaum, 1986; Rosenbaum and Hudson, 1988).

Borehole magnetic field and magnetic susceptibility logs have been used at the NTS to aid correlations among volcanic strata penetrated by drillholes. Interpretation of these logs has been largely empirical. At Yucca Mountain such logs have been obtained from several. holes, and for the first time these logs can be compared to laboratory rock magnetic data from drill core samples. Laboratory data demonstrate that remanent magnetiration is generally much larger than induced magnetization (Koenigsberger ratio, Q>5) so that the character of magnetic field logs is determined by variations in remanent magnetization. Therefore, contacts between ash-flow sheets of opposite magnetic polarity, such as the reversely magnetized Tram Member and the normally magnetized Bullfrog Member, can be easily recognized from the magnetic field logs. Both the log data and the laboratory data show high-amplitude (often order of magnitude) systematic variations in remanent intensity and susceptibility. These variations occur within the interiors of individia: ash-flow sheets as well as at the margins. These variations provide a means of using borehole data to map zones within the ash-flow sheets throughout the repository area, and to thereby contribute directly to 
knowledge about the lateral continuity of the various beds and of structures offsetting those beds.

Studies of magnetic properties have concentrated on the relationship among the observed systematic variations in remanent magnetization and magnetic susceptibility and the depositional and cooling histories of the various ash-flow sheets (Hagstrum et al., 1980; Rosenbaum and Snyder, 1985; Rosenbaum and Spengler, 1986). Bath (1968) noted a correlation between the degree of welding and values of both remanent magnetization and susceptibility. Results from Yucca Mountain confirm that nonwelded to poorly welded tuffs are generally characterized by low susceptibilities and magnetizations. However, large variations in both remanent magnetization and susceptibility occur within the thick densely-welded parts of individual cooling units penetrated by boreholes at Yucca Mountain. Studies of rock magnetic properties and Fe-oxide microcrystals have demonstrated that increases in susceptibility and remanent magnetization away from cooling breaks are produced by the growth of Fe-oxide microcrystals away from the quenched margins of the ash-flow sheets (Rosenbaum and Schlinger, 1987; Schlinger et al., 1988). In addition, there is a high degree of correlation between the location of depositional break within the thick cooling units (which may or may not correlate with changes in the degree of welding) and susceptibility minima (Rosenbaum and Spengler, 1986). Understanding the sources of variations in remanent magnetization and susceptibility. will provide the basis for improved interpretation of borehole magnetic field and susceptibility logs, and thereby for mapping of tuff layers at Yucca Mountain. Knowledge of the lateral continuity of these layers is essential to determining the structural integrity and hydrologic character of the repository block.

Magnetic property data are also useful for the interpretation of ground magnetic and aeromagnetic data. (Hagstrum et al., 1980; Rosenbaum and snyder, 1985). Four areally extensive ash-flow sheets possess moderate to strong magnetizations throughout large stratigraphic thicknesses, and are thus considered likely sources of aeromagnetic anomalies. Remanent magnetization is more important than induced magnetization $(Q>5)$; therefore, anomalies reflect magnetic polarity of the ash-flow sheets. The Tiva Canyon and Pah Canyon Members of the Paintbrush Tuff and the Tram Member of the Crater Flat Tuff are reversed, and the Topopah Spring Member of the Eaintbrush Tuff and the Bullfrog Member of the Crater Flat Tuff are normal (Table 2.2-2) (Rosenbaum and Snyder, 1985).

Paleomagnetic studies on surface outcrops of the young basaltic rocks of the Crater flat area have also begun. These studies, combined with K-Ar and Ar40/Ar39 dating of basalts, are intended to evaluate the episodic nature of late Tertiary volcanic activity in the vicinity of Yucca Mountain. Paleomagnetic measurements and interpretation will improve the resolution of separate volcanic events in the geologic record.

\section{SUMMARY OF RESULTS}

One of the most important results is the discovery of a number of magnetic anomalies over alluvial areas in Crater Flat and the Amargosa Desert 
Table 2.2-2. Magnetic properties of volcanic stratigraphy at the sitea

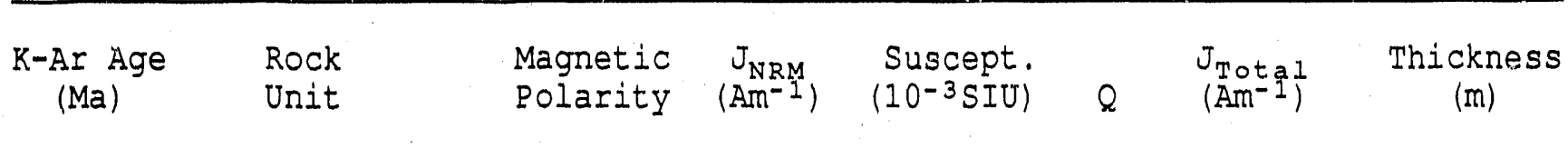

10.2 Basalt dikes

Timber Mtn Tuff

Rainier Mesa Mbr $\quad 0-46$

$\begin{array}{ll}\text { bedded tuff } & 0-61\end{array}$

12.5 Paintbrush Tuff

$\begin{array}{lllllll}\text { Tiva Canyon Mbr } & R & 0.4-10 & 2-11 & 2-38 & 0.3-10 & 69-148\end{array}$

bedded tuff

Yucca Mtn Mbr

bedded tuff

Pah Canyon Mbr

bedded tuff

13.1 Topopah Spring Mbr.

R $\quad 0.1-0.4 \quad 5-6 \quad 1-2 \quad 0.1-0.2 \quad 0-29$

$R \quad \begin{array}{llll}0.3-3.3 \quad 4-6 \quad 9-17 & 1.6-3.1 & 0-47\end{array}$

hedded tuff

R. $0.2-1.3 \quad 1-5 \quad 0-9$

$0.2-1.3 \quad 1-5 \quad 2-10 \quad 0.2-1.4 \quad 287-359$

$1-17$

13.4 Tuffaceous beds of

Calico Hills

bedced tuff

$0.1 \quad 1-2 \quad 2 \quad 0.1-0.2 \quad 27-289$

Crater Flat Tuff

Prow Pass Mbr

bedded tuff

13.5 Bullfrog Mbr

bedded tuff

Tram Member

bedded tuff

$\mathrm{N} \quad 0.1-0.5 \quad 1-3 \quad 2-20 \quad 0.1-0.6 \quad 80-1.93$

$N=0.1-2.8 \quad 1-8 \quad 5-16 \quad 0.2-5.5 \quad 2-10$

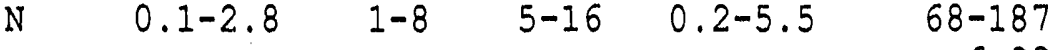

$R \quad 0.1-2.2 \quad 1-5 \quad 3-13 \quad 0.1-2.0 \quad 190-369$

$3-50$

Dacite lava and flow breccia

bedded tuff

$\mathrm{N} \quad \begin{array}{llllll}0.1-3.1 & 3-30 & 0.3-9 & 0.2-3.8 & 0-249\end{array}$

Lithic Ridge Tuff bedded tuff

I $\quad 0.2-0.3$

$3-5$

1

$0.1-0.3$

$185-304$

$3-7$

13.9 Older volcanic rocks $-\quad 0.1-1.3 \quad 1-43 \quad 1-27 \quad 0.1-3.0 \quad 345+$

\begin{abstract}
age is in millions of years before present. polarity symbols: $N$ - normal, $R$ - reversed, I - intermediate. $J_{N R M}$ is the range of intensity of natural magnetization, suscept. is the range of SI susceptibility, $Q$ is the range of the Koenigsberger ratio of $J_{N R M}$ to induced magnetization, $J_{\text {Total }}$ is the range of intensity of total magnetization using the direction of remanent magnetization. Thickness is the range in meters of rock units from surface or drill core from the Yucca Mountain area. Mbr means Member. The table was compiled from Table 3 of USGS (1984b) and Tables 2, 5, 6, 8, 9, 11, 13, 15, 16, 18, and 20 of Rosenbaum and Snyder (1985).
\end{abstract}


just west and south of Yucca Mountain. These magnetic anomalies are very similar to those associated with exposed Quaternary cinder cones and basalt flows. If this correlation is confirmed by planned drilling, the magnetic data could be used in combination with other methods and drilling to estimare the total volume of buried volcanic rocks that must be considered in evaluating the probability for future eruptions that could affect repository performance (Kane and Bracken, 1983; Crowe et al., 1986).

Another significant finding is the presence of an east-west trending magnetic high over northern Yucca Mountain, extending eastward across Calico Hills (Boynton et al., 1963a). This magnetic high is associated with magnetite-bearing, thermally altered argillaceous basement rocks of the Eleana Formation (USGS, 1984b, Figure 23; Bath and Jahren, 1984). The Eleana Formation may be altered in this location because it is at the margin of the Timber Mountain caldera (Kane et al., 1981). The magnetic high is similar in areal size and direction to the anomaiy known to be associated with Mesozoic intrusive rocks at the north edge of Yucca Valley (Bath et al., 1983). The possible relation of this feature to the larje hydraulic gradient area is discussed in Section 3.1.2.

Elongate magnetic highs and associated lows are associated with mapped faults in the site area, some of which are only partially exposed (Kane and Bracken, 1983). The extent and continuity of such faults with depth are important concerns for site characterization, and it appears that high-resolution magnetic surveys combined with other geophysical methods may provide useful resolution of these features.

Analysis of the statistical properties of magnetic anomalies in the Yucca Mountain region has produced estimates of the depth within the earth's crust to the Curie-temperature isotherm - about $580^{\circ} \mathrm{C}$ depending chiefly on the amount of titanium present in magnetic ninerals. Results from Curie isotherm analysis indicate that the isotherm deptr: in the vicinity of Yucca Mountain is about 15 $\mathrm{km}$, and that the depth increases northward to a value of about $30 \mathrm{~km}$ coinciding with an anomalously low heat flow near $38^{\circ} \mathrm{N}, 116^{\circ} \mathrm{W}$ east of Tonopah, Nevada (Blakely, 1988, Figure 10). This interpretation conflicts with the conclusion of Sass et al. (1971) that low heat flow in this area is caused by near-surface hydrologic phenomena.

The southern tip of Yucca Mountain has undergoue about $30^{\circ}$ of clockvise vertical-axis rotation since emplacement of the Tiva Canyon Member of the Paintbrush Tuff. This conclusion is based on declinations of remanent magnetization from 32 sites in the reversely magnetized Tiva Canyon Member that display a systematic southward increase over the $25 \mathrm{~km}$ north-south extent of Yucca Mountain. The observed rotations could reflect either oroflexure above a deep-seated right-lateral shear zone or shear related to differential extension within hanging-wall rocks of a regional detachment system.

Borehole magnetic field and magnetic susceptibility logs as well as laboratory magnetic property measurements demonstrate the existence of high-amplitude, systematic variations in both remanent magnetization and susceptibility through thick volcanic sections penetrated by boreholes at yucca Mountain. The magnetic property variations are intimately related to the depositional and cooling histories of the various ash-flow sheets. These 
results provide a basis for the future use of borehcle magnetic logs to map volcanic strata throughout the repository area.

\section{BIBLIOGRAPHY FOR SECTION 2.2}

Bath, G.D., 1968. Aeromagnetic Ancmalies Related to Remanent Magnetization in Volcanic Rock, Nevada Test Site, Geological Society of America Memoir. 110 , p. 135-146.

Bath, G.D., and C.E. Jahren, 1984. Interpretations of Magnetic Anomalies at a Potential Repository Site Located in the Yucca Mountain Area, Nevada Test Site, U.S. Geological Survey Open File Report 84-120, 40 p.

Bath, G.D., 1985. Investigation of an Aeromagnetic Anomaly on the West Side of Yucca Mountain, Nye County, Nevada, J.S. Geological Survey Open File Report 85-459, $24 \mathrm{p}$.

Bath, G.D., C.E. Jahren, J.G. Rosenbaum, and M.J. Baldwin, 1983. "Magnetic Investigations, " p. 40-77 in Geologic and Geophysical Investigations of Climax Stock Intrusive, Nevada, U.S. Geological Survey Open File Report 83-377, $82 \mathrm{p}$.

Blakely, R.J., 1988. "Curie Temperature Isotherm Analysis and Tectonic Implications of Aeromagnetic Data from Nevada," Journal of Geophysical Research, vol. 93, no. B10, pp. 11,817-11,832.

Boynton, G.R., J.I. Meuschke, and J.I. Vargo, 1963a. "Aeromagnetic Map of the Timber Mountain Quadrangle and Part of the Silent Canyon Quadrangle, Nye County, Nevada," U.S. Geological Survey Geophysical Investigations Map GP-443, scale $1: 62,500$.

Boynton, G.R., J.I. Meuschke, and J.L. Vargo, 1963b. "Aeromagnetic Map of the Tippipah Spring Quadrangle and Parts of the Papoose Lake and Wheelbarrow Peak Quadrangles, Nye County, Nevada," U.S. Geological Survey Geophysical Investigations Map GP-441, scale 1:62,500.

Boynton, G.R., and J.L. Vargo, 1963. "Aeromagnetic Map of the Topopah Spring Quadrangle and Part of the Bare Mountain Quadrangle, Nye County, Nevada," U.S. Geological Survey Map GP-440, scale 1:62,500.

Carr, M.D., and J.C. Yount (eds), 1988. Geologic and Hydrologic Investigations of a Potential Nuclear waste Disposal Site at Yucca Mountain, Southern Nevada, U.S. Geological Survey Bulletin 1790, 152 p. plus 2 plates, scale $1: 2,500,000$.

Crowe, B.M., K.H. Wohletz, D.H. Vaniman, E. Gladney, and N. Bower, 1986. Status of Volcanic Hazard Studies for the Nevada Nuclear Waste Storage Investigations, Los Alamos National Laboratory Report LA-9325-MS, vol. 2.

DOE (U.S. Department of Energy), 1979. Airborne Gamma-Ray Spectrometer and Magnetometer Survey, Death Valley Quadrangle, California, Nevada, U.S. 
Department of Energy Open File Report GJBX-164 (79), vol, 2, variously paged.

DOE (U.S. Department of Energy), 1988. Site Characterization Plan, Yucca Mountain Site, Nevada Research and Development Area, Nevada, U.S. Department of Energy Report RW-0199, 9 volumes.

Erwin, J.W., S.I. Nichols, R.H. Godson, and P.I. Hill, 1980. "Aeromagnetic Map Index of Nevada," Nevada Bureal ,f Mines and Geology Map 62, scale $1: 1,000,000$.

Hagstrum, J.T., J.J. Daniels, and J.H. Scott, 1980. Analysis of the Magnetic Susceptibility Well Log in Drillinole UE25a-5, Yucca Mountain, Nevada Test Site, U.S. Geological Survey Open File Report 80-1263, $33 \mathrm{p}$.

Hildenbrand, T.G., and R.P. Kucks, 1988. "Total Intensity Magnetic Anomaly Map of Nevada," Nevada Bureau of Mines and Geology Map 93A, scale $1: 750,000$.

Hildenbrand, T.G., A.M. Rogers, H.W. Oliver, S.C. Harmsen, J.K. Nakata, and M.D. Carr, 1988. "Regional Geological and Geophysical Maps of the Southern Great Basin," p. 3-21 in Carr, M.D., and J.C. Yount, Geologic and Hydrologic Investigations of a Potential Nuclear Waste Disposal Site at Yucca Mountain, Southern Nevada, U.S. Geological Survey Bulletin 1790, 152 p. plus 2 clear film plates.

Hill, P.I., 1986. Bibliography, Index, and Location Maps of Airborne Surveys. In and West of the Rocky Mountain States, U.S. Geological Survey Open File Report 86-525A, 200 p.

Kane, M.F., and R.E. Bracken, 1983. "Aeromagnetic Map of Yucca Mountain and Surrounding Regions, Southwest Nevada: U.S. Geological Survey Open File Report 83-616, scale 1:48,000.

Kane, M.F., M.W. Webring, and B.K. Bhattacharyya, 1981. A Preliminary Analysis of Gravity and Aeromagnetic Surveys of the Timber Mountain Area, Southern Nevada: U.S. Geological Survey Open File Report 81-189, 40 p. plus 6 illustrations.

Oliver, H.W., and D.A. Ponce, 1987. U.S. Geological Survey Scientific Investigation Plan - Geophysical Investigations, Gravity and Magnetic Methods, U.S. Geological Survey Administrative Report 3221G-01RO, 27 p. plus 5 illus.

Ponce, D.A., 1984. "Gravity and Magnetic Evilience for a Granitic Intrusion Near Wahmonie Site, Nevada Test Site, Nevada," Journal of Geophysical Research, vol. 89, no. B11, p. 9401-9413.

Rosenbaum, J.G., 1986. "Paleomagnetic Directional Dispersion Produced by Plastic Deformation in a Thick Miocene Welded Tuff, Southern Nevada: Implications for Welding Temperatures," Journal of Geophysical Research, vol. 91, no. B12, p. 12,817-12,834. 
Rosenbaum, J.G., and M.R. Hudson, 1988. "Paleomagnetic Investigation of Tertiary Rotations, Southwest Nevada-Yucca Mountain" (abs), EOS, vol. 69, no. 44, p. 1164.

Rosenbaum J.G., and W.C. Rivers, 1985. Paleomagist.c Orientation of Core from Drilihole USW GU-3, Yucca Mcuntain, Nevada: Tiva Canyon Mernber of the Paintbrush Tuff, U.S. Geological Survey Open File Report 85-48, 116 p.

Rosenbaum, J.G., and C.M. Schlinger, 1987. "Magnetic Property Variations and the Origin of Paleomagnetic Carriers in an Ash Flow Sheet at Yucca Mountain, Nevada" (abs), EOS (Transactions of the American Geophysical Union), v. 68, p. 1250.

Rosenbaum, J.G., and D.B. Snyder, 1985. Preliminary Interpretation of Paleomagnetic and Magnetic Property Data from Drillholes USW G-1, G-2, GU-3, G-3, VH-1, and Surface Localities in the Vicinity of Yucca Mountain, Nye County, Nevada, U.S. Geological Survey Open File Report 85-49, 73 p.

Rosenbaum, J.G., and R.W. Spengler, 1986. "Variation in Magnetic Properties in Thick Section of the Crater Flat Tuff, Southern Nevada" (abs.), EOS, v. 67, p. 924.

Saltus, R.W., and D.A. Ponce, 1988. "Aeromagnetic Map of Nevada, Las Vegas Sheet," Nevada Bureau of Mines and Geology, Map 95, scale 1:250,000, includes Merged Aeromagnetic Map, scale 1:1,000,000.

Saltus, R.W., and D.B. Snyder, 1986. "Aeromagnetic Map of Nevada, Caliente Sheet," Nevada Bureau of Mines and Geology Map 89, scale 1:250,000, includes Merged Aeromagnetic Map, scale 1:1,000,000.

Sass, J.H., A.H. Lachenbruch, R.J. Monroe, G.W. Greene, and T.H. Moses, Jr., 1971. "Heat Flow in the Western United States," Journal of Geophysical Research, vol. 76, p. 6376-6413.

Schlinger, C.M., J.G. Rosenbaum, and D.R. Veblen, 1988. "FE-Oxide Microcrystals in Welded Tuff from Southern Nevada: Origin of Remanence Carriers by Precipitation in Volcanic Glass," Geology, vol. i6, p. 556-559.

Scott, R.B., and J.G. Rosenbaum, 1986. "Evidence of Rotation about a Vertical Axis during Extension at Yucca Mountain, Southern Nevada" (abs.)," EOS, vol. 67 , no. 16, p. 358 .

Snyder, D.B., and H.W. Oliver, 1981. Preliminary Results of Gravity Investigations of the Calico Hills, Nevada Test site, Nye County, Nevada, U.S. Geological Survey Open File Report 81-101, 77 p.

USGS (U.S. Geological Survey), 1967. Aeromagnetic Map of Goldfield and Cactus Peak, Nevada, U.S. Geological Survey Open File Report 67-239, scale $1: 62.500$.

USGS (U.S. Geological Survey), 1971. "Aeromagnetio Map of Parts of the Goldfield, Mariposa, and Death Valley $1^{\circ}$ BY $2^{\circ}$ Quadrangles, NevadaCalifornia," U.S. Geologizal Survey Geophysical Investigations Map GP-753, scale $1: 250,000$. 
USGS (U.S. Geological Survey), 1978. Aeromagnetic Map of the Lathrop Wells Area, Nevada, U.S. Geological Survey Open File Report 78-1103, scale $1: 62,500$.

USGS (U.S. Geological Survey), 1979. Aeromagnetic Map of the Timber Mountain Area, Nevada, U.S. Geological Survey Open File Report 79-587, scale $1: 62,500$.

USGS (U.S. Geological Survey), 1984a. Aeromagnetic Map of the Yucca Mountain Area, Nevada, U.S. Geological Survey Open File Report 84-206, scale $1: 62,500$.

USGS (U.S. Geological Survey), 1984b. A Summary of Geologic Studies through January 1, 1983, of a Potential High-Level Radioactive Waste Repository Site at Yucca Mountain, Southern Nye County, Nevada, U.S. Geological Survey Open File Report 84-792, 103 p. 


\subsection{GEOELECTRIC SURVEYS}

\section{OBJECTIVES}

The objectives of geoelectric work are to support interpretations on the existence, location, and geometry of (1) faults and altered zones, (2) magma chambers and other thermally-related deep crustal rock units, (3) economic sulfide mineralization, (4) thickness of alluvium, and (5) aquitards. Electrical resistivity and electrical polarization data are acquired with ground-based surveys. Geological interpretations are derived from geoelectric models constrained by known petrophysical relationships and borehole logs.

\section{DATA COVERAGE AND QUALITY}

Rock resistivity is affected by fluid content and mineral composition. Minerals may be conductive (e.g., most economic minerals, but few common ones), or they may render pore fluids conductive by ionic exchange. Increased porosity, rock alteration, and elevated temperature are major factors associated with decreased resistivity. Fault zones and altered rocks are geoelectric targets because they provide increased porosity for conductive fluids, and mineralogy with high ionic-exchange capacity. Compact igneous intrusions hosted by fractured or altered rock, or by sedimentary rock, are geoelectric targets because they are more resistive than the surroundings. Structural or stratigraphic features that are enriched in clay-minerals are geoelectric targets, as are melted rocks, thermal anomalies in the crust, or zones of sulfide mineralization.

One of the earlier geoelectric surveys of the Yucca Mountain area involved magnetotelluric (MT) soundings, some of which are near seismic monitoring stations of the Southern Great Basin Seismic Network (Furgerson, 1982). MT soundings provide a means of detecting and delineating resistivity contrasts corresponding to major features such as the depth and fabric of the crystalline basement, or deep structural and lithologic contacts. Structural fabric and lithologic changes are inferred from MT resistivity structure, analogous to inferences from teleseismic velocity structure. MT data interpretation can thus reduce nonuniqueness of the resulting geophysical models of earth structure. The principal objective of crustal MT sounding and profiling is characterization of deep structure of the Yucca Mountain area, using the unique aspects of the method to test geologic structural models. For shallower exploration objectives, particularly where laterally heterogeneous resistivity structure is known to exist near the surface, audio-frequency MT and telluric profiling have been applied.

Resistivity (and IP) surveys have been performed at the site area using the Schlumberger sounding method, the dipole-dipole section-profiling method, and various controlled-source electromagnetic methods. Principal objectives for these surveys were (1) fault detection and delineation such as investigation of the inferred faults in Midway Valley and Drill Hole Wash, and

(2) sounding the thickness of alluvium, the distribution of conductive 
lithologic units in the volcanic section, and the depth to the Paleozoic basement. Profiles were modeled and interpreted in two dimensions.

The extent of geoelectric surveys in the vicinity of Yucca Mountain is indicated on Figure 2.3-1. Deep MT soundings are wideiy spaced and are shown pointwise. Geoelectrical methods with shallow depth of penetration were carried out at closer spacings within smaller areas; the general locations of these surveys are shown by rectangular patterned areas in Figure 2.3-1.

Geoelectric surveys in areas $A$ and $B$ of Figure 2.3-1 were used to screen candidate repository sites prior to the selection of Yucca Mountain (Hoover et al., 1982a; Hoover et al., 1982b). A variety of electrical surveys obtained in the immediate Project area (area $C$ of Figure 2.3-1) are sumarized on Figure 2.3-2 and explained and referenced in Table 2.3-1.

Magnetotelluric and telluric surveys in area $D$ (Figure 2.3-1) consist of six audio-frequency MT (4 to $10,000 \mathrm{~Hz}$ ) soundings at $3-\mathrm{km}$ spacings, eight telluric soundings (J-ratio analysis) at 5 - to $10-\mathrm{km}$ spacing, and a single telluric-ratio line. Data in area $\mathrm{E}$ consists of 52 Schlumberger soundings, and data in area $F$ consists of 136 schlumberger soundings.

The 1982 MT data (coverage shown in Figure 2.3-1) are of high quality. analysis of the $1985 \mathrm{MT}$ data is incomplete; modern interpretive techniques (e.g., tensor impedance modeling) are being used to quantify data variability and applicability to site characterization. The 1966-1979 MT data exhibit substantial scatter. Most of the remaining geoelectric data appear to support reliable interpretation, being relatively smooth over the domain of measurement, and producing estimates of geoelectric structure that are consistent with reasonable geologic models. These data can be further evaluated by cross-comparisons between different data, and by comparison with drillhole logs.

\section{SUMMARY OF RESULTS}

Deep MT data have identified a regional, crustal anisotropy aligned with the "Walker Lane," as well as a mid-crustal conductor at approximately $20 \mathrm{~km}$ depth or less. The anisotropy has been deduced from the azimuthal orientation of multicomponent, tensorial conductivity measurements using the MT method at distributed stations. Published interpretation (Furgerson, 1982) and unpublished data (Klein, personal communication, 1989) indicate that the magnetotelluric strike is northwest, or west-northwest for most stations. The midcrustal low resistivity layer implies the effect of deep pore fluids and/or enhanced temperatures, and may indicate a transition to crustal ductility. A report that describes and interprets deep MT data acquired more recently from the Yucca Mountain region (from 1982 to 1985) is currently in preparation.

MT data also indicate variations in the resistjvity of the upper crust (2 to $5 \mathrm{~km}$ depth) that provide information on the distribution of sedimentary and volcanic rocks, with implications for the distribution of deeppenetrating, high-angle faults as well as low-angle faults. Indications on 


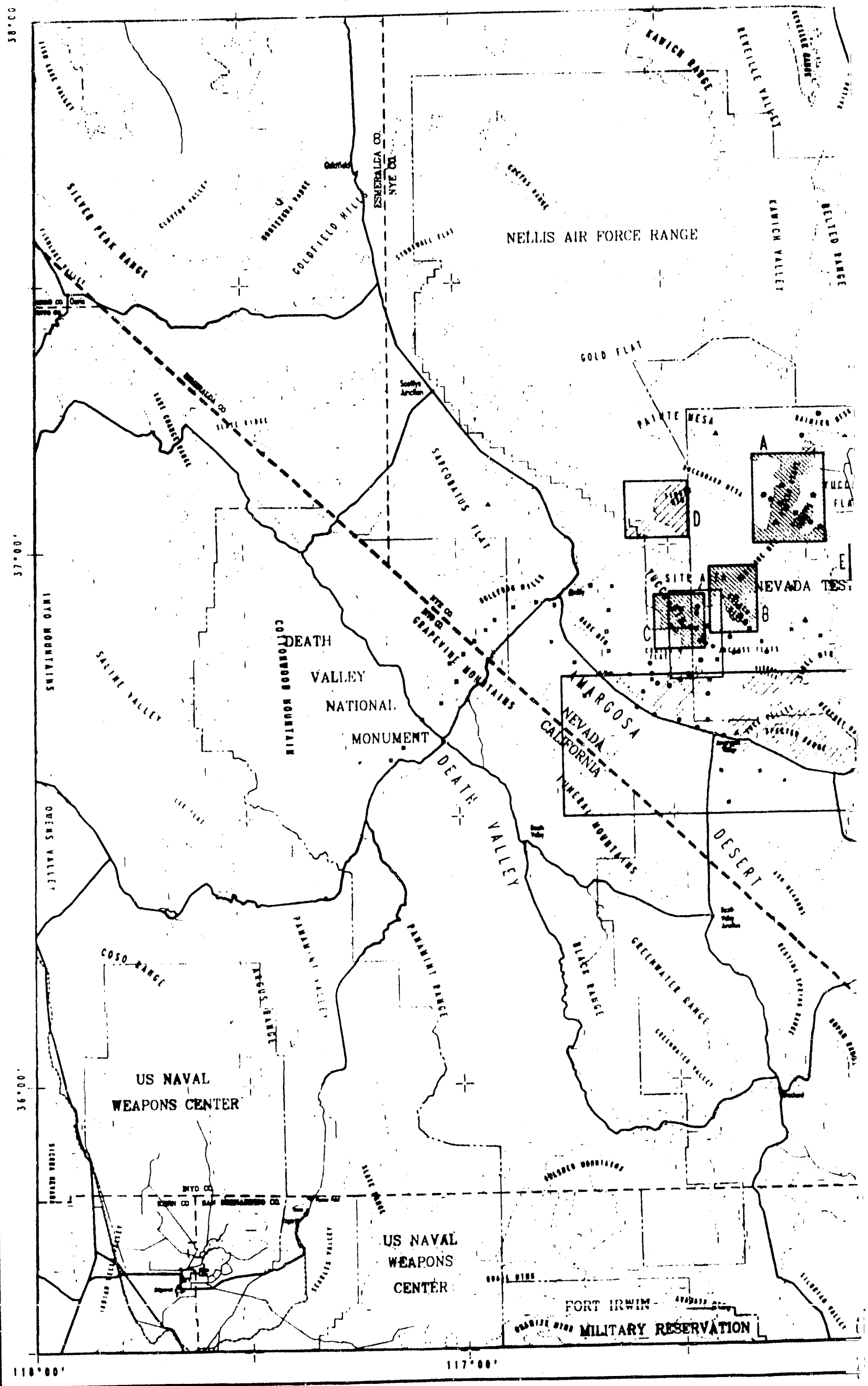




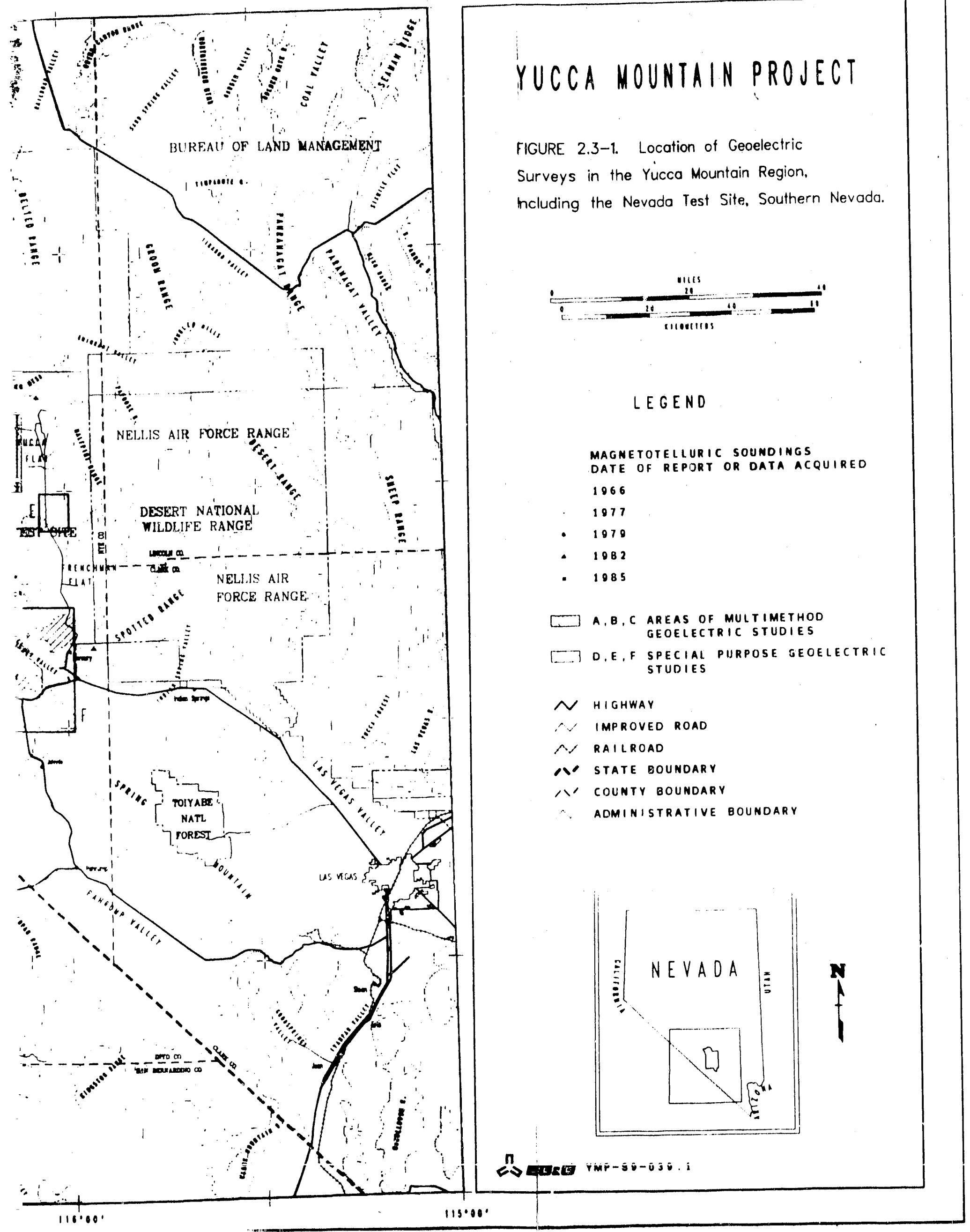




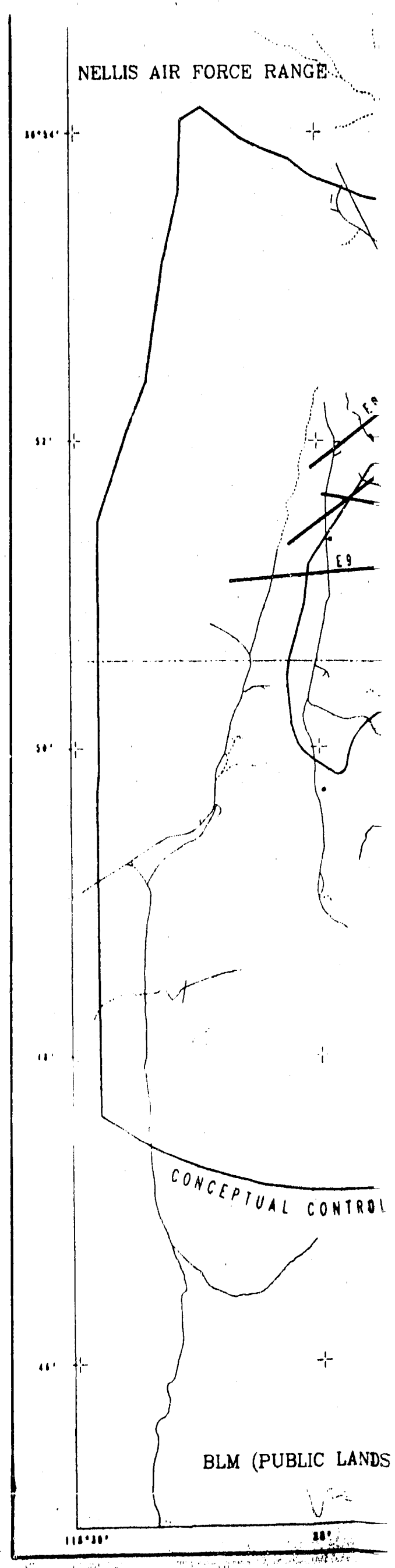




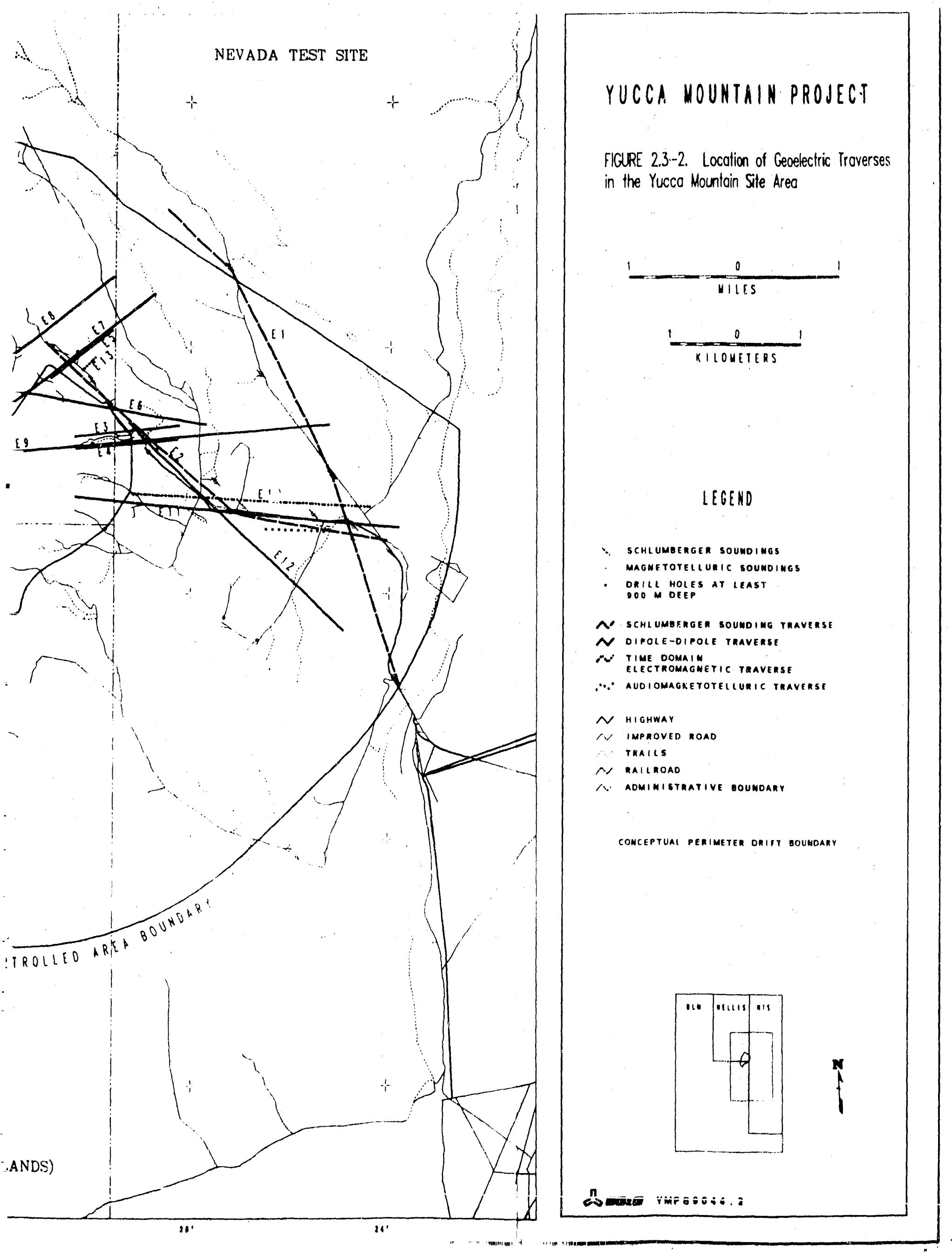




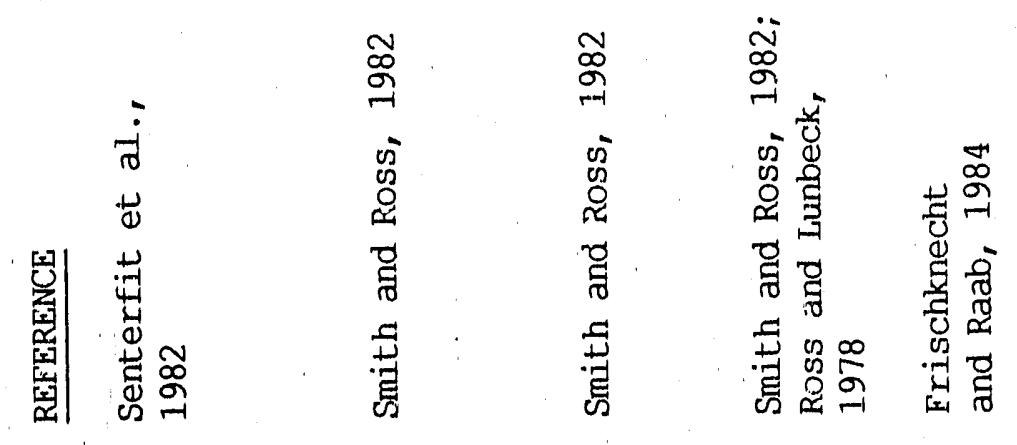

总总

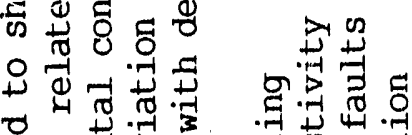

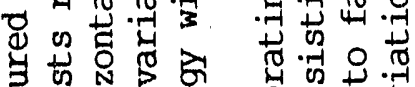

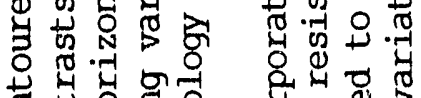

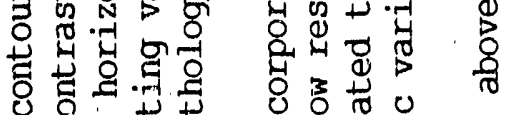

记荡 .

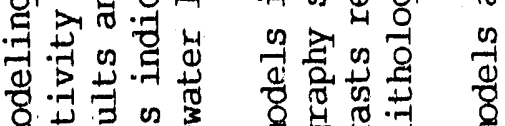

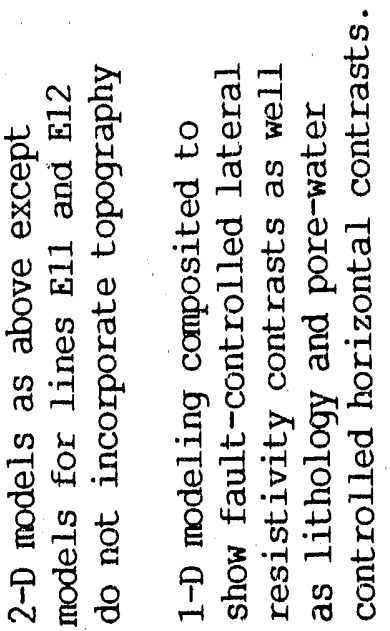

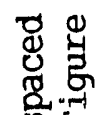

की

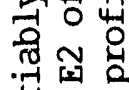

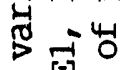

官.

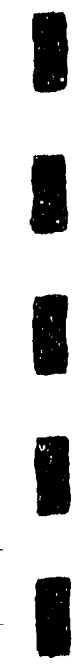

密点目

夏焉

क्ष

엉

苨䱛

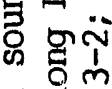

ㅍำ

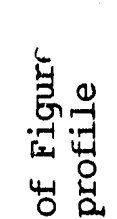

논

丮基

जिष

章

2.

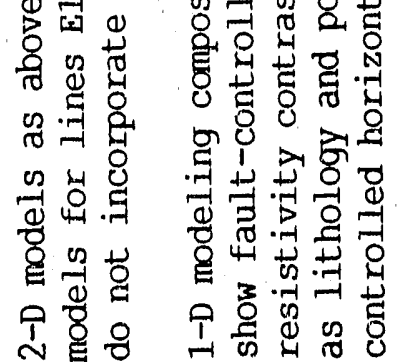

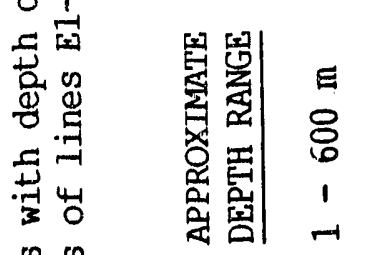

똥 ह

总告

舟

$\leqslant \frac{5}{\infty}$

$\infty$

घू ̃े

$\rightarrow N$

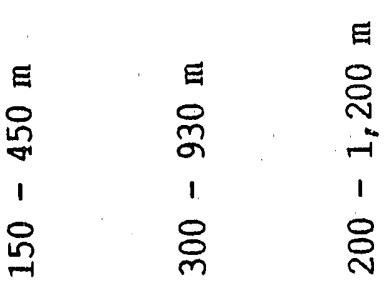

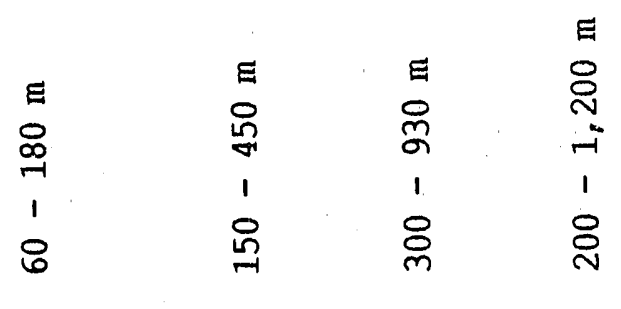

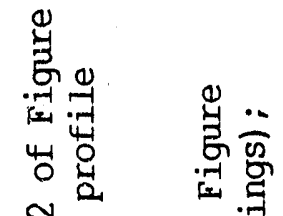

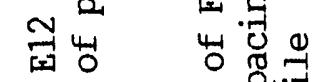

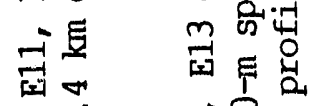

बำ

ต

वै

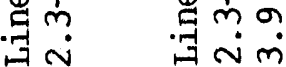

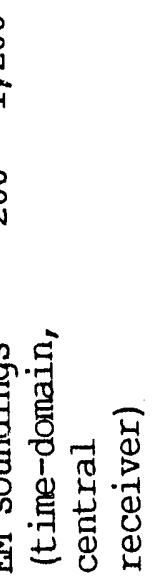




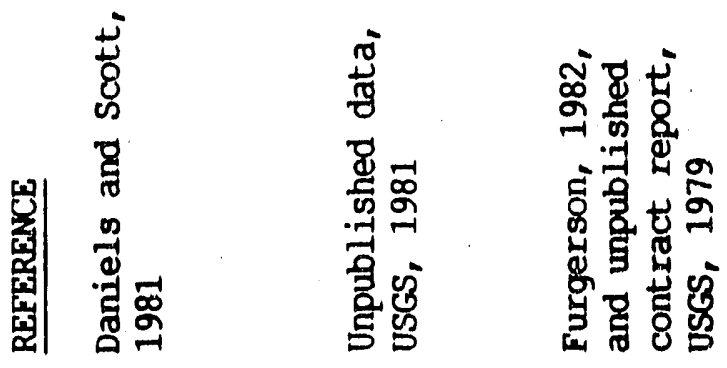

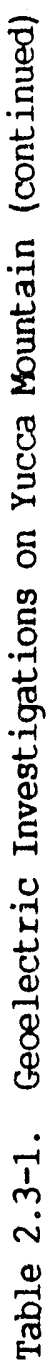

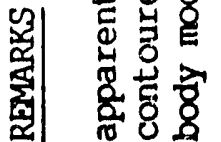

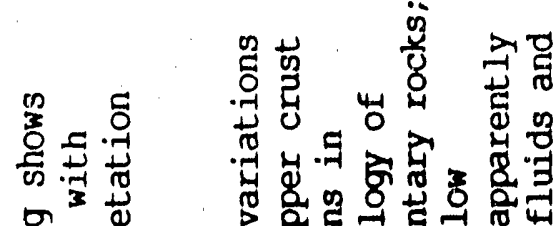

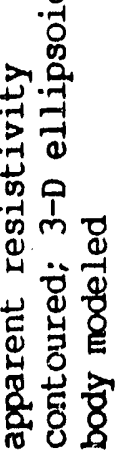

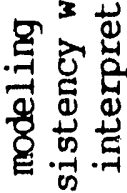

呈

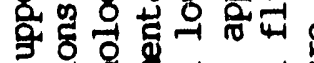

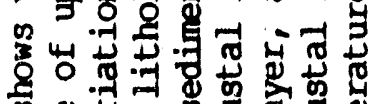

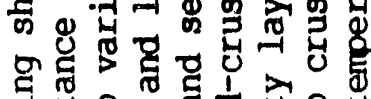

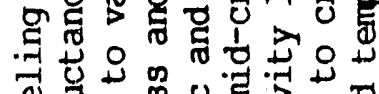

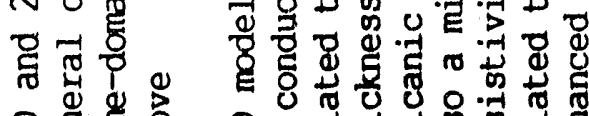

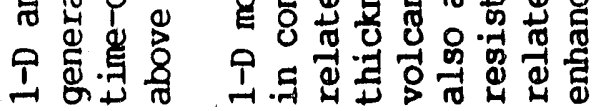

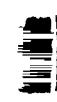

苛

류 菌

8 更

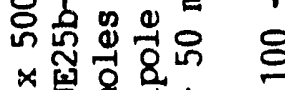

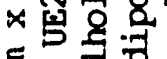

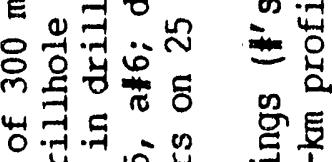

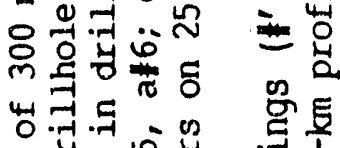

छ)

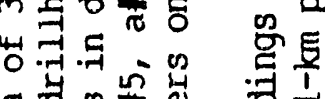

总出造

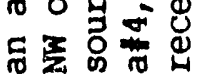

总显

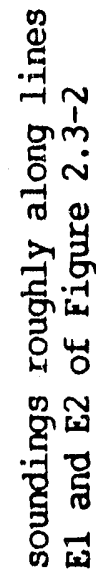

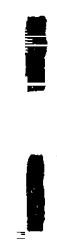

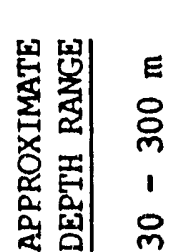

E

용

N

$\begin{array}{ll}1 & \text { N } \\ \text { ㅇ } & 1\end{array}$

II

II

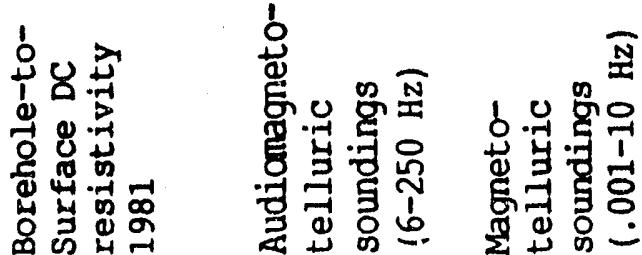



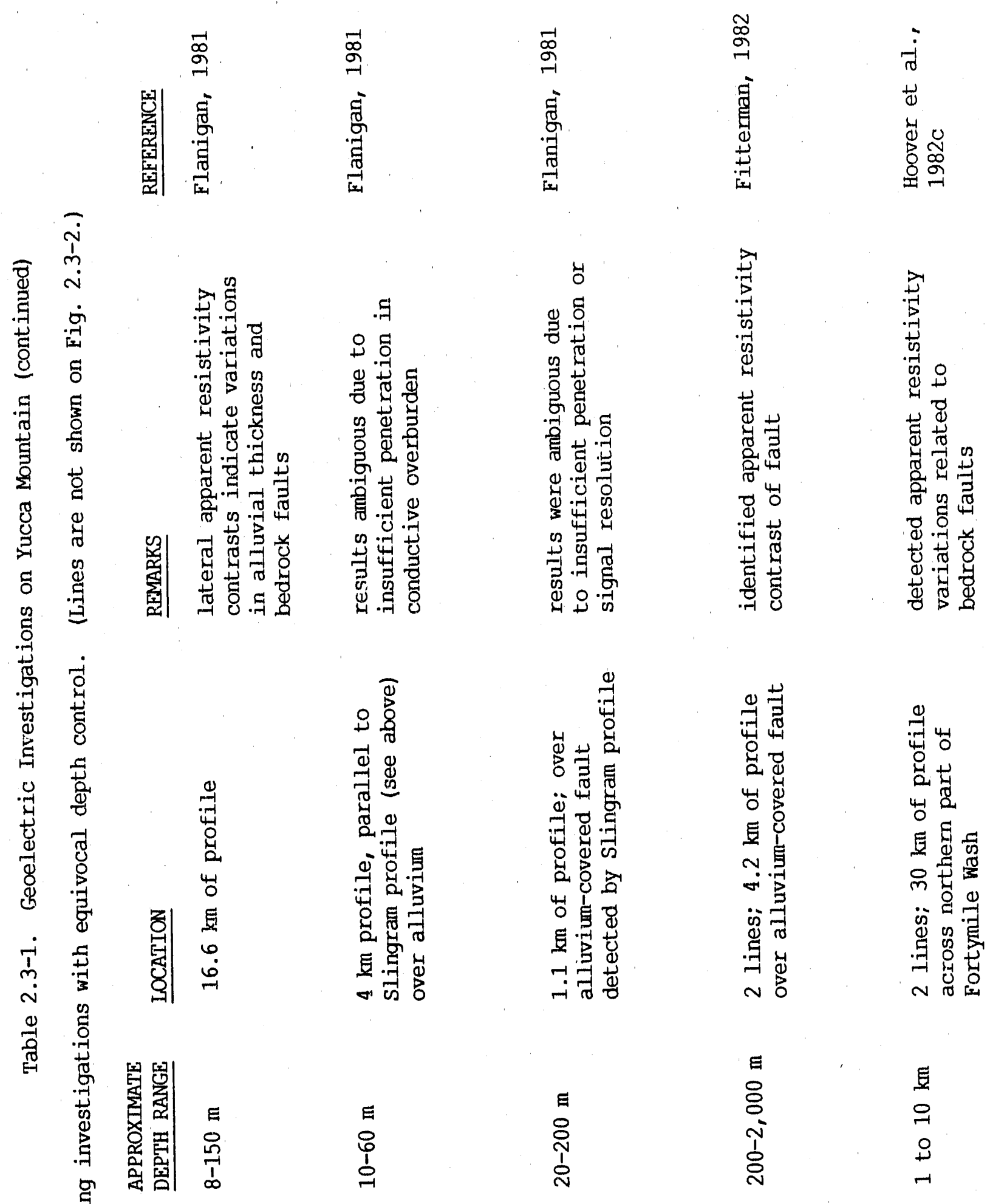

.7

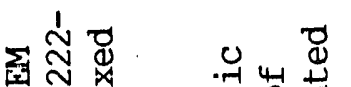

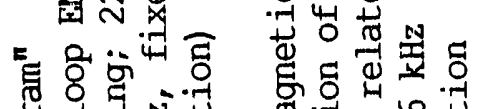

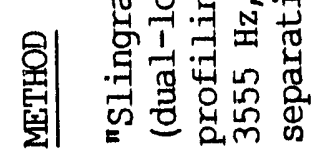

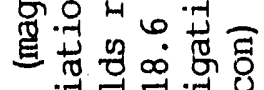

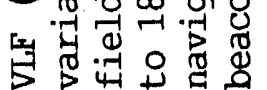

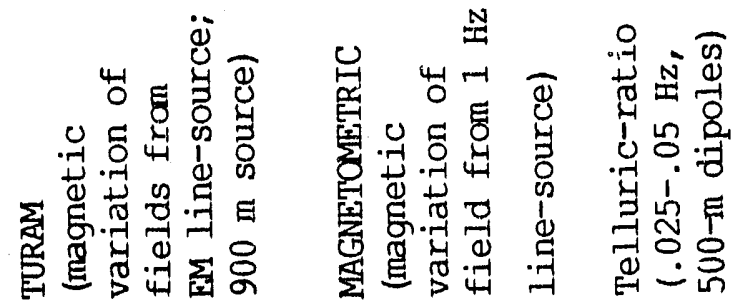


how such structural features can be detected are provided by Hoover et al. $(1982 a, b)$.

Shallower penetrating geoelectric methods applied at various locations throughout the Yucca Mountain region have indicated faults, intrusive rocks, zones of altered rocks, and the thickness of alluvial cover. The reports of Hovver at al. (1982a,b), although pertaining to syncline Ridge and the Wahmonie/Calico Hills areas and not Yucca Mountain, indicate that shallower penetrating methods have appropriate uses in site characterization. The 136 Schlumberger resistivity soundings acquired at distributed locations throughout the Amargosa nosert; as indicated in Figure 2.3-3 (Greenhaus and zablocki, 1982), have been used for mapping the depth to the Paleozoic basement (Czarnecki and catfield, 1987). Aeromagnetic data were used in conjunction with the Schlumberger data to establish the extent of Tertiary volcanics intervening between alluvium and the Paleozoic section. Apparent depths to the Paleozoic contact vary from about $200 \mathrm{~m}$ to as much as $1,500 \mathrm{~m}$; deeper values are aligned in apparent fault-controlled basin structures in the northern part of the Amargosa Desert. In addition to depth-to-basement interpretation, inferred differences in resistivity of the upper $75 \mathrm{~m}$ of alluvium were used in conjunction with driller's logs to illentify areas with coarser and probably more transmissive sediments.

The numerous survey lines on the northeast flank of Yucca Mountain were situated mostly on alluvial surface cover of variable thickness. Some lines extended on to tuff units, mostly of the Paintbrush Tuff (Lines E1 and E13 in Figure 2.3-2). Most of these data were in the vicinity of Drill Hole Wash northeast of the repository site. The results were interpreted to indicate various mapped and unmapped faul.ts as lateral contrasts associated with zones of low resistivity. Most of the data sets (Figure 2.3-2) were interpreted independently from one another for purposes of fault detection. Interpretations were typically based on characteristic responses to conductive zores, or on models derived from one-dimensional (layered earth) algorithms, the composited results of which provided quasi-2-D sections. A notable exception is the dipole-dipole data set, a portion of which was modeled with a 2-D algorithm that incorporated topography as well as subsurface bodies.

In overview (Klein, personal communication, July 1989), the available geoelectric data suggest structural complexity in the vicinity of Drill Hole Wash, but uniformly high resistivity in the repository block. However, the data sets have not been incorporated into a consistent interpretive synthesis using the best available geologic control, as was done for the area of Syncline Ridge and the Wahmonie/Calico Hills areas (Hoover et al., 1982a,b). This task is highly desirable for four reasons: (1) incorporation of the current geologic control, (2) delineation of structures and lithological units that are reliably defined among the various data sets, (3) elimination of the inconsistencies among the various topical interpretations, and (4) evaluation of the merits of the various geoelectrical approisches.

The 2-D models of the dipole-dipole profiles (Smith and Ross, 1982) show an unrealistic complexity that impedes a geologic interpretation. Studies into part of these data near coyote Wash (D. Klein, USGS, and E. Hardin, SAIC/Las Vegas, unpublished work, July 1989) indicate that the lack of incorporating geologic control and the lack of accounting for the effects of alluvial contacts may have contributed to the complexity of the models. 


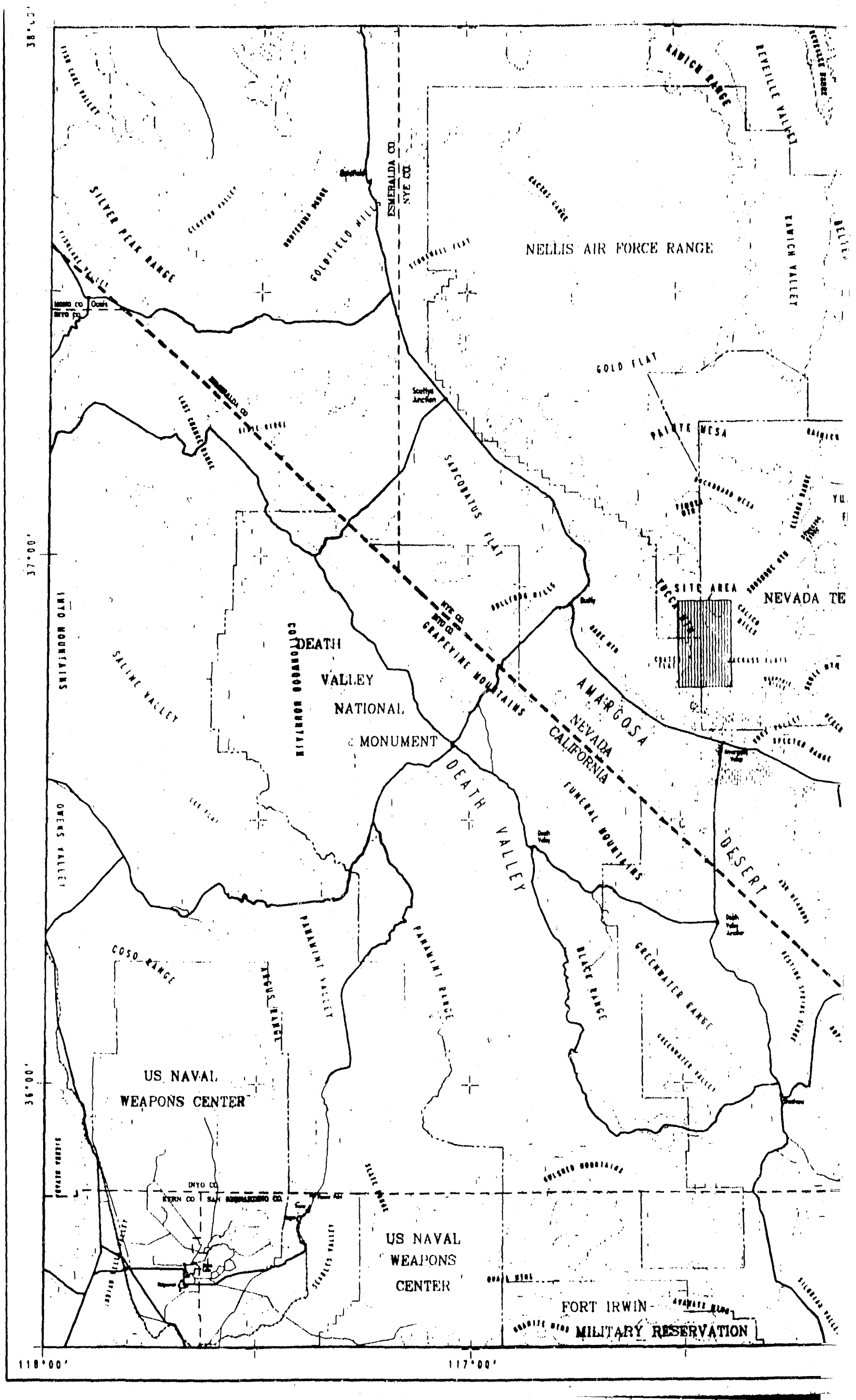




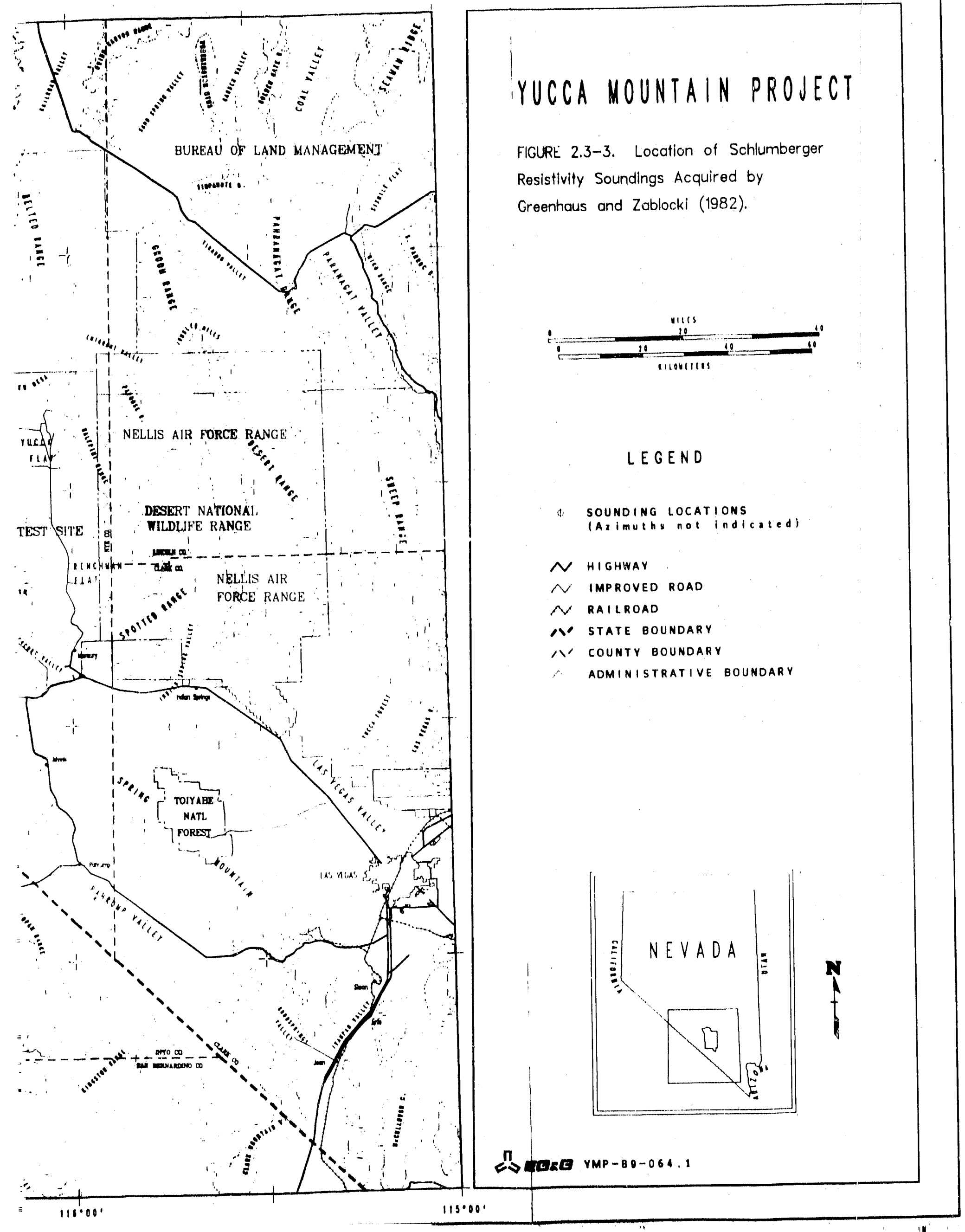


However, major features of the models appear to approximate the geologic situation known from drillhole control not available to Smith and Ross (1982). Such features include a modeled low resistivity unit corresponding to a zone of nonwelded tuff that separates the Tiva Canyon and Topopah Spring Members of the Paintbrush Tuff, and a modeled high resistivity unit corresponding to a major portion of the Topopah Spring Member. Further interpretative work is called for to identify and separate the signatures of lateral lithologic variations from the signatures of faults.

\section{BIBLIOGRAPHY FOR SECTION 2.3}

Czarnecki, J.B., and W.J. Oatfield, 1987. "Use of Drillers' Logs and Geophysical Surveys to Define the Hydrogeologic Eramework of the Amargosa Desert, Southern Nevada," EOS, Transactions, American Geophysical Union, vol. 68, no. 16, p. 302 .

Daniels, J.J., and J.H. Scott, 1981. Interpretation of Hole-to-Surface Resistivity Measurements at Yucca Mountain, Nevada T'est Site, U.S. Geological Survey Open File Report 81-1336, 23 p.

Fitterman, D.V., 1982. Magnetometric Resistivity Survey near Fortymile Wash, Nevada Test Site, Nevada, U.S. Geological Survey Open File Report 82-401, $27 \mathrm{p}$.

Flanigan, V.J., 1981. A Slingram Survey at Yucca Mountain on the Nevada Test Site, U.S. Geological Survey Open File Report 81-980, 38 p.

Frischknecht, F.C., and P.V. Raab, 1984. "Time-Domain Electromagnetic Soundings at the Nevada Test Site, Nevada," Geophysics, vol. 49, no. 7, July 1984, p. 981-992.

Furgerson, R.B., 1982. Remote-Reference Magnetotelluric Survey, Nevada Test Site and Vicinity, Nevada and California, U.S. Geological Survey Open File Report 82-465.

Greenhaus, M.R., and C.J. Zablocki, 1982. A Schlumberger Resistivity Survey of the Amargosa Desert, Southern Nevada, U.S. Geological Survey Open File Report 82-897.

Hoover, D.B., W.F. Hanna, I.A. Anderson, V.J. Flanigan, and I.W. Pankratz, 1982a. Geophysical Studies of the Syncline Ridge Area Nevada Test Site, Nye County, Nevada, U.S. Geological Survey Open File Report 82-145, 55 p.

Hoover, D.B., M.P. Chornack, K.H. Nervick, and M.M. Broker, 1982b.

Electrical Studies at the Proposed Wahmonie and Calico Hills Nuclear Waste Sites, Nevada Test Site, Nye County, Nevada, U.S. Geological Survey Open File Report $82-446,45 \mathrm{p}$.

Hoover, D.B., M.P. Chornack, M.M. Broker, 1982c. E-Eield Ratio Telluric Traverses Near Fortymile Wash, Nevada Test Site, Nevada, U.S. Geological Survey Open File Report 82-1042. 
Ross, H.P., and James Lunbeck, 1978. Interpretation of Resistivity and Induced Polarization Profiles, Calico Hills and Yucca Mountain Areas, Nevada Test Site, University of Jtah Research Institute report ESL-UURI-8.

Senterfit, R.M., D.B. Hoover, and M.P. Chornack, 1982. Resistivity Sounding Investigation by the Schlumberger Method in the Yucca Mountain and Jackass Flats Area, Nevada Test Site, Nevada, U.S. Geological Survey Open File Report 82-1043.

Smith, C., and H.P. Ross, 1982. Interpretation of Resistivity and Induced Polarization Erofiles with Severe Topographic Effects, Yucca Mountain Area, Nevada Test Site, Nevada, U.S. Geological Survey (Jen File Report 82-182. 


\subsection{SEISMIC REFRACTION SURVEYS}

\section{OBJECTIVES}

Seisnic refraction surveys have been used in the Yucca Mountain region for investigations that range from measurements of crustal thickness (regional refraction profiles; e.g., Hoffman and Mooney, 1983) to the thickness of surficial alluvial and volcanic deposits (shallow refraction profiles, or engineering refraction profiles; e.g., Pankratz, 1982). The objectives for the work discussed below thus include (1) mapping shallow velocity structure at the proposed site of the repository surface facilities; (2) obtaining velocity information for input to processing of seismic reflection sections; (3) investigating upper-crustal structure in the site area and its relation to the structure of the surrounding region; and (4) investigating the structure of the middle and lower crust, and the refrasion Moho.

High-resolution upper-crustal refraction methods and results are particularly relevant and are sumarized here in more detail. Such profiles are intermediate in scale and provide the link between shallow and regional studies. High-resolution upper-crustal refraction profiles can be tied to the deepest drillholes in the vicinity of Yucca Mountain, and can be jointly interpreted with sravity, aeromagnetic, and geoelectric data. In terms of depth of penetration $(0-5 \mathrm{~km})$ and regional extent $(40-60 \mathrm{~km}$ long lines), upper-crustal refraction profiles and seismic reflection profiles provide information on geologic structure and tectonic processes affecting performance of the Yucca Mountain site.

\section{DATA COVERAGE AND QUALITY}

The following discussion covers all refraction studies conducted by the Yucca Mountain Project, in the site area and regionally. The discussion is organized as follows: (1) shallow profiles in the vicinity of Yucca Mountain are discussed first (Pankratz, 1982), followed by (2) additional low-energy surveys to measure near-surface velocities (Rodriguez and Yount, in USGS, 1988), (3) an early study involving high-explosive (HE) and underground nuclear explosion (UNE) sources (Hoffman and Mooney, 1983), and

(4) high-resolution upper-crustal profiles in the Yucca Mountain region (Mooney and Schapper, written communication; Ackermann et a].., in USGS, 1988).

Three shallow, HE-source, reversed refraction profiles were run in 1982 in the vicinity of Yucce Mountain (Pankratz, 1982). One of the profiles tied to borehole UE25 a\#1 in Drill Hole Wash, and extended partway across Midway Valley (Figure 2.4-1). An east-west line crossed Midway Valley and the southern part of Exile Hill, and a third line transected Midway Valley in a northwest orientation slightly north of Exile Hill. Each 2.7-km spread was acquired using 24 single geophones spaced $120 \mathrm{~m}$ apart, and HE shothole charges varying in size from $4 \mathrm{~kg}$ to $180 \mathrm{~kg}$. A significant increase in the size of explosive charge was required for the Yucca Mountain lines compared to similar lines run in the Calico Hills and Wahmonie areas (Pankratz, 1982). 
Data were analyzed using an interactive ray-tracing program (Pankratz, 1982; Ackermann, 1979) to associate critically refracted rays with first arrivals. Of the three profiles, two yielded arrival data that were interpretable by this method. Interpretation of the velocity section for the profile that was tied to borehole UE25 a\#1 deviates significantly from the stratigraphic section and the downhole velocity survey from this borehole. The author attributes this discrepancy to various causes, including poor picks of first arrivals, low-velocity layers, and the possible existence of a major off-axis vertical velocity discontinuity. The line crossing the Paintbrush Canyon fauit on the eastern margin of Midway Valley indicates a significant offset east of the surface scarp, suggesting the existence of another fault within the Fran Ridge/Alice Hill horst block. Additional drilling has been conducted in Midway Valley since the Pankratz (1982) surveys were run, which could potentially provide additional constraints for interpretation of these lines.

The velocities determined from the seismic data indicate that the in situ compressional velocity is on the order of $1.0 \mathrm{~km} / \mathrm{sec}$ for the surface alluvium, and only 1.7 to $2.6 \mathrm{~km} / \mathrm{sec}$ for the Tiva Canyon and part of the upper part of the Topopah Spring Members. Note that the intact-rock velocities reported for the large volume core samples by Anderson (1984) for these units are about $4.5 \mathrm{~km} / \mathrm{sec}$ for the Tiva Canyon Member, and 3.0 to 4.5 $\mathrm{km} / \mathrm{sec}$ for the upper part of the Topopah Spring.

A survey of compressional refraction velocities, for alluvial units at five locations distributed across the Yucca Mountain region, was reported by Rodriguez and Yount (in USGS, 1988). The study compared the velocities of alluvial layers of various age at survey areas in Rock Valley, crater Flat, Beatty area, Fortymile Wash area, and Frenchman Flat. Using a sledgehammer source and closely-spaced geophones, a number of short profiles were acquired in areas where the alluvial deposits were exposed in mapped trenches that were excavated for tectonics and other studies. A strong correlation was observed between compressional velocity and age (particularly Holocene vs. Quaternary). Some older alluvial units showed development of caliche-rich cemented horizons at the upper boundary; these features evidently gave rise to higher velocity, leading to speculation about the characteristics of an older unit from which the upper carbonate-cemented horizon had been eroded away, but which was otherwise present. This question was not resolved by the stidy. The alluvium velocities reported are low, in the range of 0.3 to 0.5 $\mathrm{km} / \mathrm{sec}$ for the youngest (Q1 series) Quaternary materials, 0.7 to $1.1 \mathrm{~km} / \mathrm{sec}$ for older ( $Q 2$ series) Quaternary materials, and 1.2 to $1.8 \mathrm{~km} / \mathrm{sec}$ for pre-Quaternary alluvial materials.

Refraction studies using UNE and HE sources to penetrate the crust and upper crust were conducted hy the USGS in 1980 and 1981 (Hoffman and Mooney, 1983). Up to 100 portable seismographs were arrayed along lines across Yucca Mountain and Jackass Flats, northward from the Amargosa Desert through Crater Flat, and from Yucca Mountain south to southern Death Valley. The lines were set up to coincide with three UNE shots on the NTS, and one HE shot detonated near Beatty, Nevada. The information provided from the HE profile pertained. mostly to the upper crust, and the first arrivals from the UNE shots travelled along the seismic basement, i.e., a crustal layer with a seismic velocity of about $6 \mathrm{~km} / \mathrm{sec}$. 
NELLIS AIR FORCE R

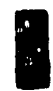

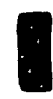

I

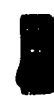

I

I

1

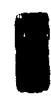

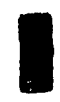

1

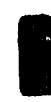

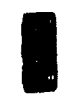

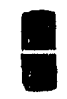

1

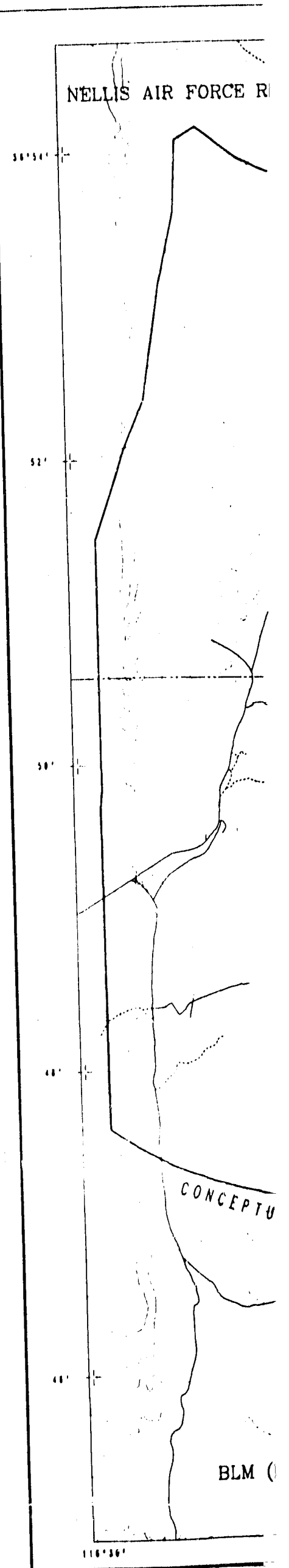

4, 


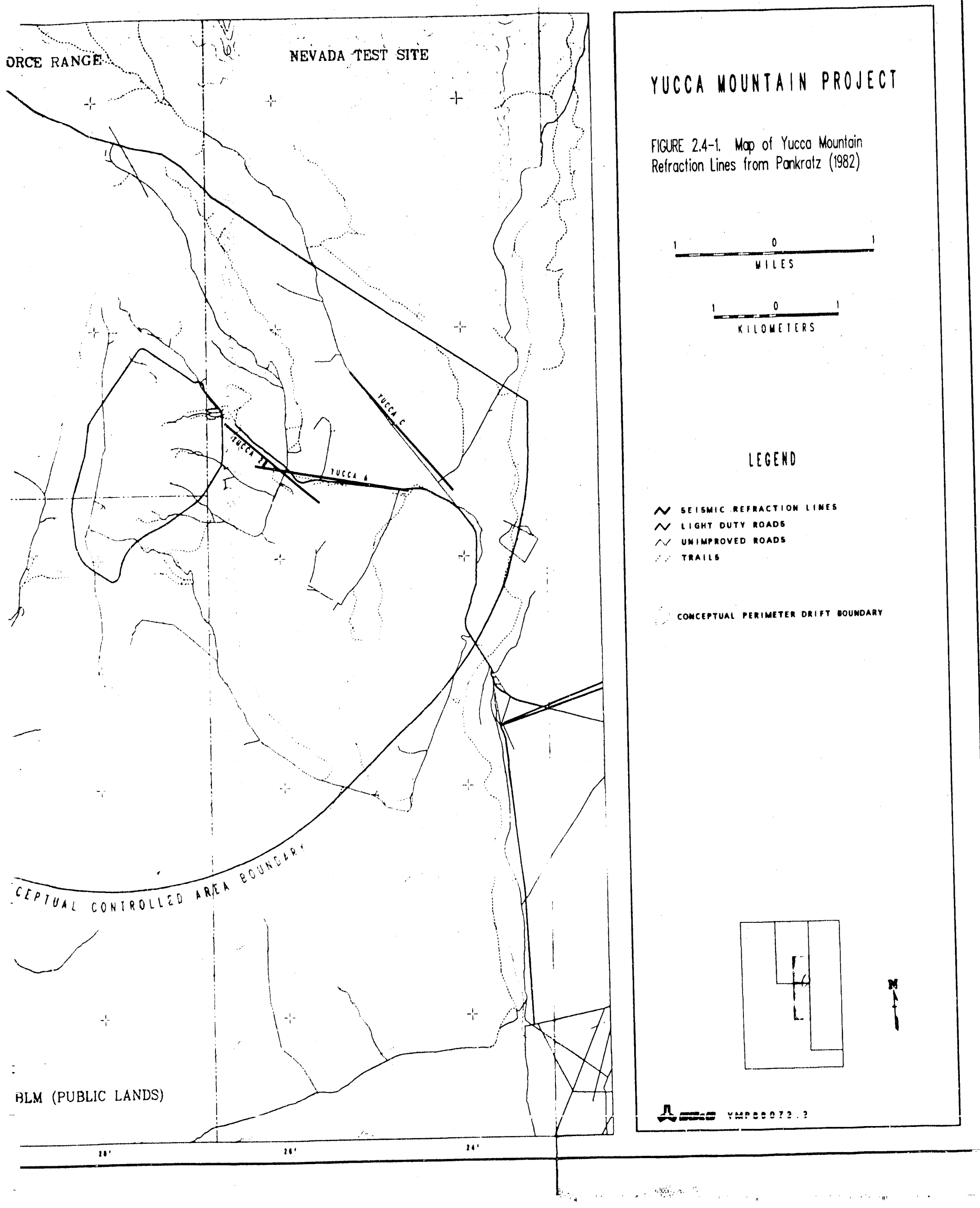


Travel times (reduced to $6 \mathrm{~km} / \mathrm{sec}$ ) for the UNE events revealed delays (proportional to greater basement depth) of 1.2 to $1.4 \mathrm{sec}$ for Crater Flat and Yucca Mountain, 0.8 to $1.2 \mathrm{sec}$ for Jackass Flats, and 0.4 to $0.8 \mathrm{sec}$ for Bare Mountain and Skull Mountain. The P-wave delays were interpreted by aciapting the density-depth model of Snyder and Carr (1982) to velocity, producing a model of monotonically increasing velocity with depth. The results of multiple profiles, and the velocities reported by Pankratz (1982), were used to constrain the velocity model. On this basis, the depth to the Paleozoic basement was estimated to be $3.2 \mathrm{~km}$ beneath Crater Flat, and $1.1 \mathrm{~km}$ beneath Jackass Flats. The largest $\mathrm{P}$-wave delays were observed in Crater Flat and northern Yucca Mountain, where the tuff section may be thickest. The UNE work aiso revealed a strong midcrustal reflector at about $15 \mathrm{~km}$ depth, from rays bottoming beneath Yucca Mountain and eastern Crater Flat. Deeper crustal reflectors were observed at 24 and $30 \mathrm{~km}$, and total crustal thickness was estimated to be $35 \mathrm{~km}$.

Travel times for the upper-crustal HE profile were modeled to within about $50 \mathrm{msec}$ of observed values using a ray-tracing method. Unlike the gravity model of Crater Flat, the HE-source refraction profile shows evidence for a buried bench-like structure between the Bare Mountain range front and Crater Flat. (This part of the profile also corresponds to certain irregularities in the survey geometry.)

The present coverage of high-resolution upper-crustal seismic refraction profiles is indicated on Figure 2.4-2. Initial field tests, including the evaluation of shot sizes, noise levels, and seismic energy propagation characteristic were started in 1980 (Hoffman and Mooney, 1983). Two detailed profiles were collected in 1983: one in a north-south direction in Crater Flat (Crater Flat profile) and a second in an east-west direction from northern Crater Flat, south of Beatty, Nevada, to the Grapevine Mountains (Beatty profile). Interpretation of these profiles is presented by Ackermann et al. (in USGS, 1988). Three additional profiles were acquired in 1985 (Figure 2.4-2): (1) an east-west profile across Yucca Mountain from the northern Amargosa Valley to Jackass Flats (Yucca Mountain profile); (2) a north-south profile along Fortymile Wash, east of Yucca Mountain (Fortymile Wash profile; and (3) an east-west profile within the Amargosa Valley south of Yucca Mountain (Amargosa profile). Interpretation of these profiles is presented by Mooney and Schapper (written communication).

The data were collected by a seismic crew from the USGS, Menlo Park, California. Surveying was accomplished with topographic maps and a laser electronic-distance-measuring instrument. Energy sources consisted of high-yield chemical charges of up to $1,800 \mathrm{~kg}$, in $50 \mathrm{~m}$ drillholes. Shot holes were spaced at approzimately 8 to $15 \mathrm{~km}$ intervals along the profiles. Data were recorded at an effective sampling rate of $200 \mathrm{~Hz}$, using 120 portable event recorders, each equipped with a $2 \mathrm{~Hz}$ vertical-component seismometer. Data quality on all profiles is very good to excellent. Recordings were made at night when wind and cultural noise were minimal, and large shot sizes were used. Specifics about these surveys, such as shot point and recorder locations and plots of ground motion data, are presented by Sutton (1984, 1985).

In order to avoid uncertainties inherent in trial-and-error modeling, these refraction profiles were recorded with field parameters satisfying the 
requirements of a method for direct inversion of the data (Ackermann et al., 1982). The primary requirements for the data inversion method are close spatial sampling, and frequency of shot points along the profile. The attributes of these high-resolution upper-crustal profiles easily exceed the mininum requirements. As a result, the derived crustal models are considered to be reliable: seismic velocities and layer depths are $\epsilon$ stimated to be accurate to about 5 to 108 based on comparison with drillhole stratigraphic control and the mis-tie of crossing profiles. However, there are limitations to the survey methods and interpretation as listed below:

1. Since shot hole sources were used, it is not always possible to space the shots uniformly along the profiles because of limited access. (Seismographs are self-contained and portable, and can be transported by helicopter to any location.) A missed or displaced shot point can introduce interpretive uncertainty in the vicinity. For the profiles described, it was not possible to place shots on top of either Bare Mountain or Yucca Mountain, leading to some ambiguity regarding steep interfaces: (a) on the east flank of Bare Mountain, and (b) on the west flank of Yucca Mountain. Closely spaced gravity data (e.g., Snyder and Carr, 1984) have been used to reduce these ambiguities.

2. Because of the scattering of seismic energy within the thick volcanic sequence, it is often difficult to identify secondary reflected arrivals in the seismic data. Although the arrivals of secondary phases cannot be determined as accurately as first arrivals, secondary arrivals can often confirm layer depths determined from first arrival analysis. For the profiles described above, the lack of clear secondary arrivals has been compensated for by tying the five profiles at cross-points (Figure 2.4-2), and by locating the profiles as close as possible to deep drillholes (e.g., Scott and Castellanos, 1984) for better stratigraphic and velocity control.

3. There is no unique relationship between seismic velocities determined from the seismic refraction profiles and composition (i.e., geologic interpretation) or density (i.e., as needed for gravity modeling). This means there are ambiguities in the structural and geologic interpretations of seismic velocity models. For the profiles described above, these ambiguities have been minimized by using stratigraphic control and density logs obtained from deep drillholes coincident with or adjacent to the seismic refraction profiles.

\section{SUMMARY OF RESULTS}

The shallow refraction study reported by Pankratz (1982) suggests that the method is potentially effective at Yucca Mountain, and produced profiles across Midway Valley that represent the type of structural information needed elsewhere in the site area. As pointed out early in the report, the usefulness of the method depends on resolution of the discrepancy between the velocity model developed, and downhole velocity surveys at nearby boreholes. 


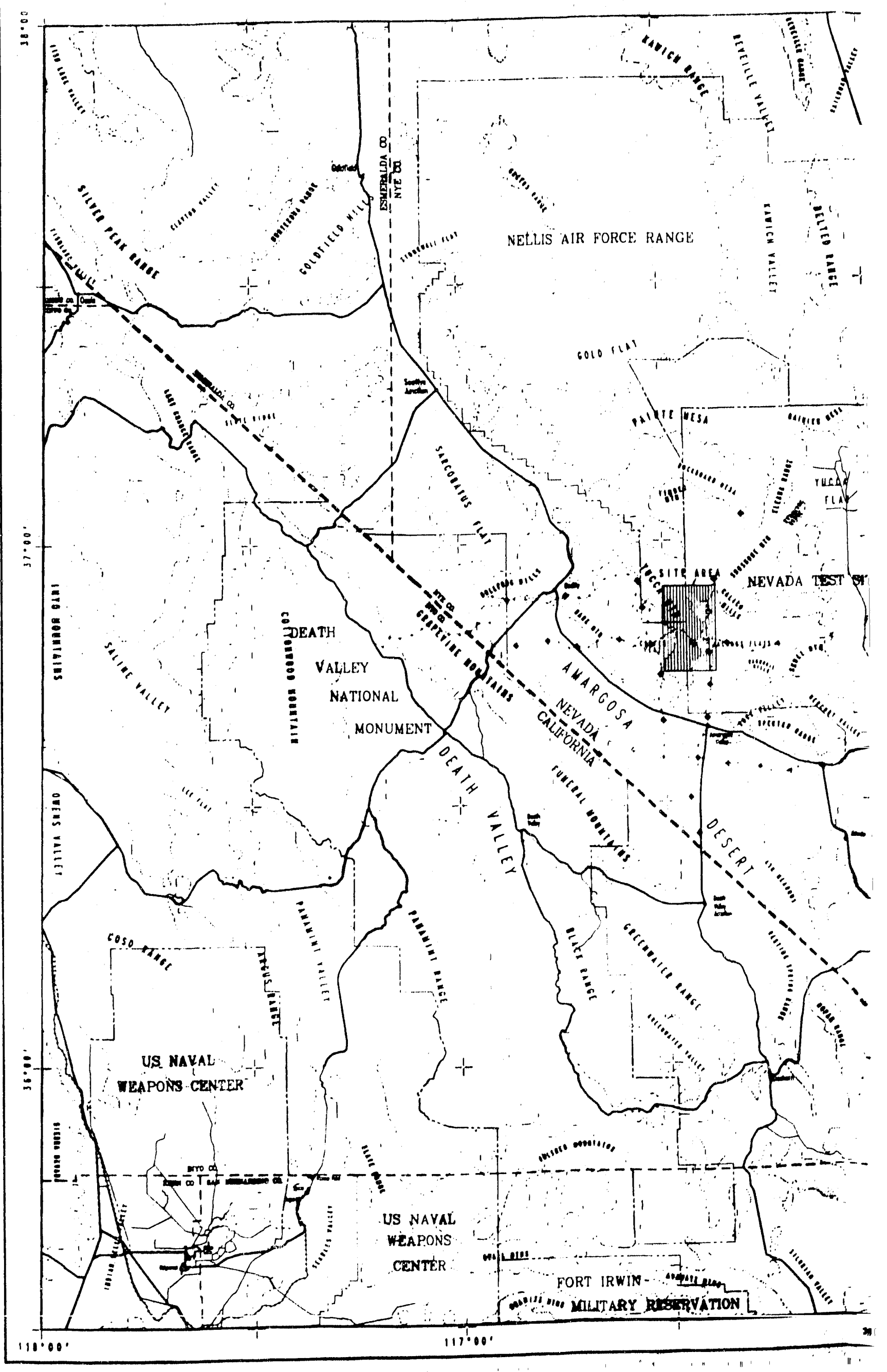


Also, the method used to invert the travel time data has not been analyzed with respect to sensitivity of the results to travel time error, or other sources of interference and noise that may be present at the site area.

High-resolution, upper-crustal seismic refraction profiles (and deep seismic reflection profiles) provide the most useful information regarding geologic structure of the Yucca Mountain site, relative to other types of refraction studies, in terms of resolution, depth of penetration $(0-5 \mathrm{~km})$, and regional extent $(40-60 \mathrm{~km}$ lines). These profiles can potentiaily be tied to control from the deepest exploratory drillholes, and can be reliably interpreted in conjunction with other geophysical data (i.e., gravity, aeromagnetic, and geoelectric surveys).

High-resolution seismic refraction profiles recorded across and around Yucca Mountain have provided reconnaissance of the general upper-crustal $(0-5 \mathrm{~km})$ structure near the Yucca Mountain site. Interpretation suggests seven distinct upper-crustal refracting layers, corresponding to successive alluvial, volcanic, and pre-volcanic (Paleozoic) units. This result is in agreement with velocity data from other surveys at the site area, and with borehole control.

Interpretation of the five available refraction profiles defines the proposed repository site as overlying complex extensional features manifested in the pre-Tertiary strata. The velocity contrast between the Tertiary (mainly volcanic) and pre-Tertiary sections is large enough that, when interpreted together with the borehole and gravity data, a more reliable representation of the pre-Tertiary surface is produced. A large structural depression is apparent beneath Crater Flat; it is an asymmetrical, westward-deepening structure that extends from the Bare Mountain front to the eastern flank of Yucca Mountain.

\section{BIBLIOGRAPHY FOR SECTION 2.4}

Ackermann, H.D., L.W. Pancratz, and D.A. Dansereau, 1982. A Comprehensive System for Interpreting Seismic Refraction Arrival-Time Data Using Interactive Computer Methods, U.S. Geological Survey open File Report $82-1065$.

Ackermann, H.D., W.D. Mooney, D.B. Snyder, and V.D. Sutton, 1988. "Preliminary Interpretation of Seismic Refraction and Gravity Studies West of Yucca Mountain, Nevada and California," in Carr, M.D., and J.C. Yount, (eds), Short Contributions to the Geology and Hydrology of a Potential Nuclear Waste Site at Yucca Mountain, Southern Nevada, U.S. Geological Survey Bulletin 1790, p. 23-33.

Anderson, I.A., 1984. Rock Property Measurements on Large-Volume Core Samples from Yucca Mountain USW GU-3/G-3 and USW G-4 Boreholes, Nevada Test Site, Nevada, U.S. Geological Survey Open File Report 84-552.

Hamilton, W.B., 1987. "Crustal Extension in the Basin and Range Province, Southwestern United States," in Coward, M.P., J.F. Dewey, and Society Special Publication no. 28, p. 155-176. 
Hoffman, L.R., and W.D. Mooney, 1983. A Seismic Study of Yucca Mountain and Vicinity, Southern Nevada: Data Report and Preliminary Results, U.S. Geological Survey Open File Report 83-588, 50 p., l plate.

Mooney, I.R., and S.G. Schapper, written communication. "Report on the Status of Regional Geophysics, NNWSI Program: Seismic Refraction Profiles," 27 p., 8 figures (technical report submitted November 1988 to USGS/NNWSI management).

Pankratz, I.W., 1982. Reconnaissance Seismic Refraction Studies of Calico Hills, Wahmonie, and Yucca Mountain, Southwest Nevada Test Site, Nye County, Nevada, U.S. Geological Survey Open File Report 82-478, 25 p.

Rodriguez, E.A., and J.C. Yount, 1988. Relation Between P-Wave Velocity and Stratigraphy of Late Cenozoic Deposits in Southern Nevada, U.S. Geological Survey Bulletin 1790, p. 139-146.

Scott, R.B., and M. Castellanos, 1984. Stratigraphic and Structural Relations of Volcanic Rocks in Drillholes USW GU-3 and USW G-3, Yucca Mountain, Nye County, Nevada, U.S. Geological Survey Open File Report 84-491, 121 p., 1 plate.

Snyder, D.B., and W.J. Carr, 1984. "Interpretation of Gravity Data in a Complex Volcano-Tectonic Setting, Southwestern Nevada," Journal of Geophysical Research, vol, 89, p. 10,193-10,206.

Sutton, V.D., 1984. Data Report for the 1983 Seismic Refraction Experiment at Yucca Mountain, Beatty, and Vicinity, Southwestern Nevada, U.S. Geological Survey Open File Report 84-661, 66 p., 11 plates.

Sutton, V.D., 1985. Data Report for the 1985 Seismic Refraction Experiment at Yucca Mountain, Beatty, and Vicinity, Southwestern Nevada, U.S. Geological Survey Open File Report 85-591, 96 pp., 17 plates. 


\subsection{SEISMIC REFLECTION SURVEYS}

Seismic reflection surveys relevant to site characterization may be broadly categorized as shallow, intermediate-depth, or deep methods:

1. Shallow penetrating (up to about $1 \mathrm{sec}$ ), high-resolution profiling performed in the Yucca Mountain site area using vibrator, explosive, or weight-drop energy sources; and reflection profiling performed at locations distributed across the Yucca Mountain region using the Mini-Sosie method.

2. Intermediate-depth profiles (up to several seconds) from areas of the NTS explored as prospective areas for underground nuclear testing, and from resource-related speculative lines in the Yucca Mountain region.

3. Deep seismic reflection (up to about $15 \mathrm{sec}$ ) such as the test line acquired recently in Amargosa Valley, and other regional profiles run in Death Valley and in various parts of the Basin and Range Province.

This section will summarize the objectives, data quality and coverage, and results from past work, organized according to these categories. All of the existing seismic reflection data or past reflection surveys of any type, known to be relevant to site characterization, are listed in Table 2.5-1.

\subsubsection{SHALIOW, HIGH-RESOLUTION REFLECTION PROFILING}

\section{OBJECTIVES}

The following discussion summarizes past uses for shallow, high-resolution profiling methods, thereby describing applicability to future studies as well. Seismic reflection methods are planned for use in establishing the continuity and regularity of important stratigraphic contacts, such as the upper and lower surfaces of the Calico Hills unit. Although reflections were expected from such contacts in past studies, no coherent reflections have been observed (see discussion of data quality below). Volcanic ash flows and ash fall deposits can exhibit lateral discontinuity depending on the conditions of deposition, such as pre-eruptive topography and the timing of eruption. Similarly, reflection methods may also be used for detection and delineation of buried volcanic deposits such as basaltic dikes or sills, which are sampled and studied as components of the geologic history of the site.

Seismic reflection methods have found important application to detection of buried faults, mapping the extent of fault zones, and investigating the subsurface geometry of fault zones. Fault detection problems may be approached using photogeology or other remote sensing techniques, but subsurface characterization may be required to determine whether a surface feature is caused by a fault (e.g., see USGS, 1988). Faults may be detected from discontinuity of reflections, or from offsets. Estimates for total fault offset can be produced for certain types of faul.ts by seismic 
Table 2.5-1. Existing Seismic Reflection Data and Past Surveys

Shallow Crustal (0-2 sec) Profiles

1. Crater Flat/Amargosa Desert - high-resolution Mini-Sosie reflection profiles acquired and processed by the USGS (USGS, 1988)

Quality - fair to good

objectives - image faults/fault offsets in Quaternary alluvium

Results - partly to fully successful imaging of fault offsets

2. Death Valley - high-resolution Mini-Sosie reflection line (L. Serpa, University of New Orleans, personal comtunication, 1988)

3. Yucca Mountain - various high-resolution profiles comissioned by the USGS discussed by McGovern et al. (1983)

Intermediate Crustal $(0-5 \mathrm{sec})$ Profiles

4. Mid Valley/Nevada Test Site - land air-gun profiling of the upper 3-5 sec of the crust (McArthur and Burkhard, 1986)

Quality - good to excellent

Objectives - map depth to Paleozoic basement in Tertiary basins

Results - successful imaging of basin fill and subhorizontal detachment faults

5. Yucca Flat/Nevada Test Site - land air-gun profiling of the upper $3-5$ sec of the crust (N. Burkhard, personal communication, 1988)

Quality - good to excellent

objectives - map depth to Paleozoic basement in Tertiary basins

Results - successful imaging of basin fill and subhorizontal detachment faults

6. Frenchman Flat/Nevada Test Site - land air-gun profiling of the upper 3-5 sec of the crust (N. Burkhard, personal communication, 1988)

Quality - good to excellent

Objectives - map depth to Paleozoic basement in Tertiary basins

Results - successful imaging of basin fill and subhorizontal detachment faults

7. Seisdata speculative lines - obtained with vibroseis and explosive sources

a. Las Vegas shear zone (Lines 8 and $8 a$ of Wasatch Cordilleran hingeline reconnaissance survey)

Quality - poor to fair

Objectives - map Tertiary basins for hydrocarbon exploration

Results - successfully obtained reflections from only the upper $1 \mathrm{sec}$ 
Table 2.5-1. Existing Seismic Reflection Data and Past Surveys (continued)

7. Seisdata speculative lines - obtained with vibroseis and explosive sources (continued)

b. Rahrump Valley (Lines 12 and 17 of Sandy speculative survey)

8. Geophysical Service Inc. speculative lines - obtained with vibroseis and explosive sources
a. Big Smokey Valley, Nevada
b. Monitor Valley, Nevada
c. Railroad Valley, Nevada
d. Tikaboo Valley, Nevada
for $a-d$ :
Quality - poor to excelient
Objectives - image Tertiary basins for hydrocarbon exploration
Results - variable success in imaging sedimentary fill of Tertiary basins

9. Other speculative data - unknown source types
a. White River Valley, Nevada
b. Garden Valley, Nevada

Quality - unknown

Objectives - image Tertiary basins for hydrocarbon exploration Results - unknown

Deep Crustal $(0-15 \mathrm{sec})$ Profiles

10. Amargosa Desert near Beatty and Lathrop Wells - deep crustal Vibroseis and explosive feasibility study (Brocher et al., 1989)

Quality - good to excellent

Objectives - image entire crust down to the Moho

Results - successful imaging of all portions of the crust

11. Death Valley/SW Amargosa Desert/S. Pahrump Valley - deep crustal

Vibroseis survey by COCORP (Serpa et al., 1988)

Quality - poor to fair

Objectives - image entire crust down to the Moho

Results - partly successful in mapping mid- to lower crustal structure 
reflection methods. High-resolution is needed because the targets are shallow, and offset distances or fault zone dimensions are typically a fraction of a wavelength. A principal objective for site characterization is the geometry of N-S striking faults with depth, particularly in the immediate vicinity of the site. The most significant infoimation needed from seismic surveys is the attitude of the subsurface extensions of faults proximal to Yucca Mountain, i.e., whether they are coplanar with surface indications, or listric, at depths on the order of 1 to $3 \mathrm{~km}$. A related objective is to characterize the nature of tilting and warping associated with faulting. (Results obtained so far from Yucca Mountain have not been of appropriate quality for interpreting subsurface fault geornetry and related kinematics.)

\section{DATA COVERAGE AND QUALITY (Shallow, High-Resolution Reflection Profiling)}

Several field surveys have been conducted in association with the Yucca Mountain Project, using shallow reflection methods with portable equipment and limited geophone deployment. Much of the work has been performed using the Mini-Sosie method (Barbier, 1983). The salient aspects of this method are that it uses one or more portable, soil compaction vibrators as the source, and a closely spaced array of single geophones. Data quality is achieved by stacking a large number of traces, each triggered from a single vibrator cycle. Randomization of the vibrator repeat period suppresses contributions from extraneous vibrator cycles. The processing steps used in the work described here typically included common-depth-point (CDP) sorting, constant velocity analysis, normal movement correction, spectral whitening, deconvolution, bandpass filtering, datum and residual statics, and final CDP stack migration (Barbier, 1983; USGS, 1988). The method can produce useful reflections at depths corresponding to two-way travel times of about 0.3 to 1 sec, depending on site conditions. Note that the uppermost 50 to $150 \mathrm{~m}$ (depending on velocity) cannot be imaged by this method.

The following items sumarize the shallow, Mini-Sosie reflection studies performed to date in association with the Yucca Mountain Project:

1. A profile was acquired over the Carpetbag fault and the Yucca fault, using the Mini-Sosie method. The portion of the line across the Carpetbag fault produced good results, interpreted as the Rainier Mesa tuff dipping steeply into the Yucca Flat basin, with no indication of tault offset. This leads to speculation that at least at the profile location, the post-event faulting observed in association with UNEs was caused by compaction of alluvium, and slip on the steeply dipping Rainier Mesa Member of the Timber Mountain Tuff. The portion of the line crossing the Yucca fauit yielded no useful information, probably because the Rainier Mesa Member is below the $1 \mathrm{sec}$ two-way travel time, and there are no interpretable reflecting horizons in the overlying alluvium.

2. An east-west line approximately $1.1 \mathrm{~km}$ in length was run across the Beatty scarp, about $4 \mathrm{~km}$ south of Beatty, Nevada (USGS, 1988). The profile shows two bands of reflections, which are coherent beneath the Beatty scarp. The relative incoherency of the section was attributed to low contrasts between geologic layers, residual 
statics problems, and scattering by boulders near the surface (USGS, 1988). Extension of a fault from the surface scarp to a portion of the section that suggests offset would require reverse motion on a fault plane dipping 30 degrees to the west. This is inconsistent with the regional predominance of normal slip on north trending faults, iherefore the investigator opines that the Beatty scarp is not fauit related.

3. An east-west ine was run across a fault scarp (Windy Wash fault) in Crater Flat that had been investigated by means of several nearby trenches (USGS, 1988; Swadley and Hoover, 1983). The near-surface velocity structure was found to be complex. A CDP sorting and constant velocity analysis was used to determine residual statics, which were correlated somewhat with the surface distribution of Quaternary alluvial materials and extrusive Tertiary volcanics. A single reflecting horizon was traced across the section, and exhibited dipping portions and fault offset. Subsurface faulting indications were related to, but different from, those observed in nearby surface trenches. The results were interpreted not to support normal faulting mechanisis, and to be consistent with strike-slip faulting.

4. An east-west line was Iun from the east slope of Bare Mountain, between the two volcanic cones in central Crater Flat, then further into the basin toward Yucca Mountain. Some reflected energy was observed; however, the data were of iusufficient quality to substantially support or challenge the published structural model by W. Carr (USGS, 1988).

5. An east-west line was run from about $1 \mathrm{~km}$ up Tarantula Canyon in the Bare Mountain block, down into the valley toward Crater Flat. This line ris run to see if the range front fault could be imaged, and detected at the mouth cf Tarantula Canyon. However, no coherent reflections were observed at this portion of the line. Another portion does indicate a near-surface anticlinal feature oriented on-strike with a zone of faults mapped by $M$. Reheis (see Figure 8.1 of USGS, 1988).

6. A line was run along the old railroad bed east of Lathrop Wells, Nevada. These data are perhaps least informative of any yet acquired, in that the only feature to the section is a general change in character from east to west.

In addition to the Mini-Sosie work, several reflection studies of a more conventional type were performed in the Yucca Mountain site area during the 1980-22 time period. These are described in a summary report (Mcsovern, 1983) as three distinct surveys undertaken by different organizations: Colorado School of Mines (1980), Birdwell (1981), and Seisdata (1982). The recording windows for these surveys generally extended beyond $1 \mathrm{sec}$, but they are discussed here because (1) high frequency sources were used (small explosive charges; vibrator sweeps to $>100 \mathrm{~Hz}$ ), (2) the receiver arrays were small, and (3) the lines were located in the immediace site area. These surveys wore thus designed to investigate shallow reflectors, of which there may be several in the first $1 \mathrm{sec}$. The summary report presents negative 
results from these surveys, and states that useful seismic reflection data cannot be acquired from the site area. The following is a brief description of each of these studies:

1. The Colorado School of Mines (CSM) ran two lines on the eastern flank of Yucca Mountain in 1980, as shown in Figure 2.5-1. One of the lines crossed Midway Valley (perpendicular to strike) and the other extended part of the way up Drill hole wash (along strike) terminating in a side canyon. These were in-line type surveys with a single ( 8 to $120 \mathrm{~Hz}$ ) vibrator source on $55 \mathrm{ft}$ intervals (55 to 1,320 ft offsets), and single geophones placed at the same interval. No interpretable data were acquired from these lines (see also Barry, 1980).

2. A single reflection line was conducted by Birdwell, Inc., during 1981, in Drill Hole Wash (along strike) in the vicinity of drillholes USW G-1 and H-1. Based on several noise tests, a group array of 120 geophones was used in a 100 by $200 \mathrm{ft}$ pattern. Three in-line vibrators $(48$ to $6 \mathrm{~Hz}$ ) were deployed on $50 \mathrm{ft}$ stations $(500$ to 2,850 ft offsets) No reflections were observed on the raw reflection records, and improvement was not achieved from processing. Coherent noise was evident throughout the acquisition window, and when removed by velocity filtering, produced a record with no coherence basis for residual statics analysis (McGovern, 1983).

3. The Seisdata (1982) survey consisted of a series of noise studies, and four swath-type profiles. Ground roll and direct noise were observed in the noise studies, and the combined receiver and vibrator source arrays, group patterns, and source-receiver offsets were designed using the noise characteristics according to standard industry practice developed for sedimentary terrane. Surface Primacord explosive sources were tested in addition to vibrator sources, and found to produce significantly more noise than vibrators (but were used predominantly in the surveys jecause of vibrator mechanical failures). The survey also included an array of 10-25 1b. exposure shots at $200 \mathrm{ft}$ depths. The swath profiles were variously configured up to 8 stations wide and 24 stations long, with a maximum CDP fold of 384. As indicated in Figure 2.5-1, two of the lines were situated in canyons on the eastern flank of Yucca Mountain (roughly perpendicular to strike), one parallel to Exile Hill (along strike of the Bow Ridge fault), and one along the crest of a northwest trending ridge north of the site area. The processed sections presented in the summary report are the result of constant velocity moveout analysis, and sorting to maximize CDP fold. No other sorting strategy for the swath data was effective for improving coherency. Automatic residual statics were not relied upon, so as to avoid artificial lineups. One of the lines was processed by two separate contract service companies, proving uninterpretable in both cases.

Further information on the array designs, acquisition, and processing for these three studies, as well as presentation of the final processed sections, may be found in the sumbry repori (ivicGovern, 1963). 


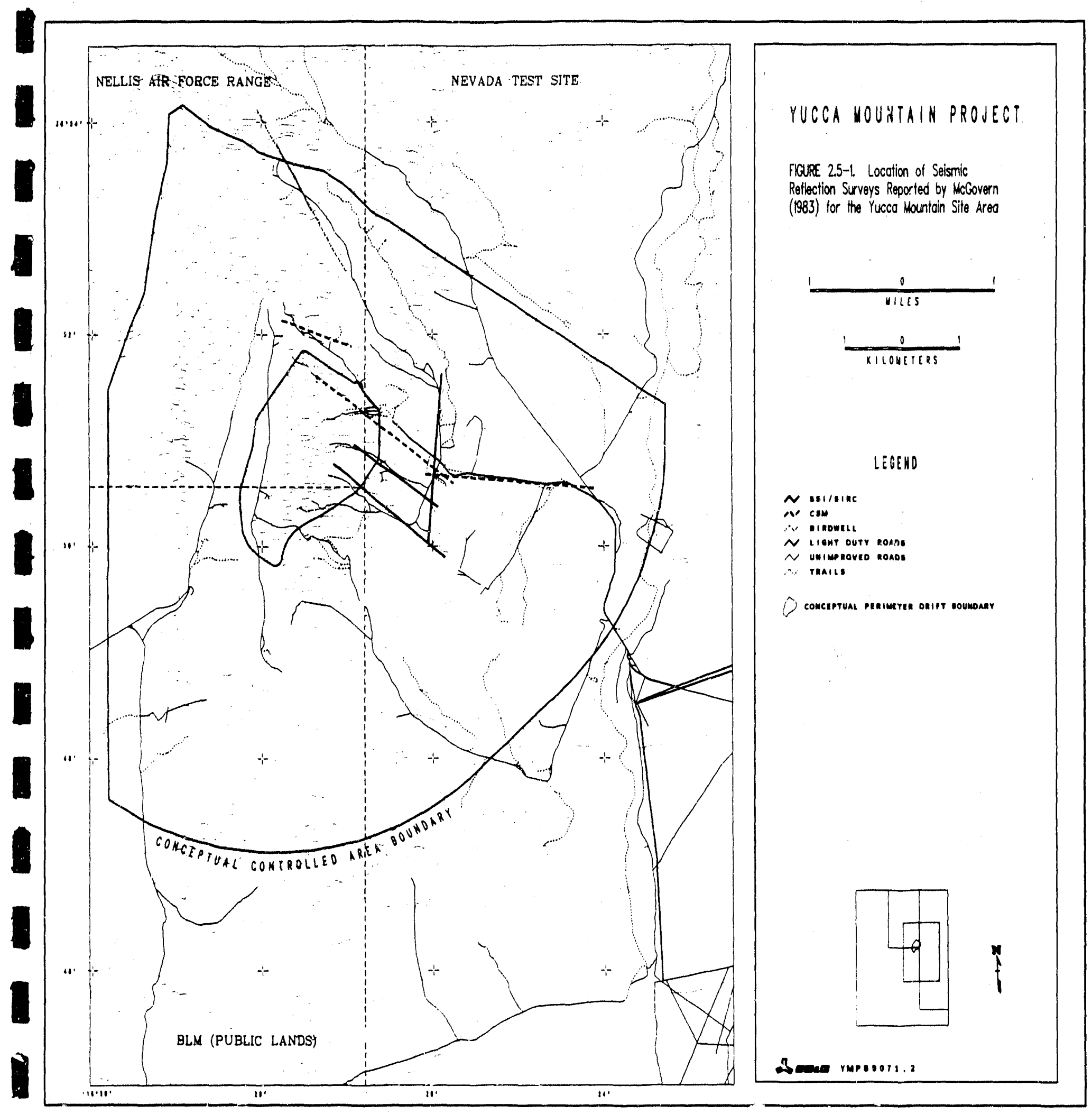


In addition to the surveys described above, several tests of other shallow reflection methods have been performed in association with the Yucca Mountain Project. Two reflection lines were run in the tunnels of Rainier Mesa with blasting caps as sources. While reflected energy was observed, its origin was unknown (reflection from below or above the tunnel, or both). The data are therefore virtually uninterpretable, and are unpublished.

Two shear wave tests have been conducted, using a sledgehammer shear wave source and closely spaced, three-component geophone arrays. One line was run at the mouth of Drill Hole Wash, in a setting where high-resolution work using P-wave sources yielded no interpretable records (McGovern, 1983; discussed below). The source consisted of a sledgehammer impinging on a fixture anchored into the ground surface. The distance between geophones was $1 \mathrm{~m}$. This test confirmed the absence of interference from generated Love waves, and produced a coherent set of arrivals that were apparently reflected from depths ranging to about $200 \mathrm{~m}$ (Hasbrouck, 1987).

The same shear wave method was tested in an east-west profile on the flank of Fran Ridge, near Yucca Mountain. The method demonstrated some facility for locating faults without reliance on offset reflectors, and for characterizing the average distribution of fractures. The test was located in fractured tuff of the Topopah Spring Member, lithologically similar to the repository host rock. Ten records acquired exhibit differences between seismograms produced by SV and SH methods, indicating possible birefringence related to fracturing. Although transmission was strongly attenuated by a relatively highly fractured portion of the outcrop, seismic arrivals could be detected to 36 meters from the source in this region. All of the records acquired ( $\mathrm{P}, \mathrm{SV}, \mathrm{SH}$ ) indicate that this portion of the profile crossed an unmapped fault (Hasbrouck, 1988).

Another set of shallow reflection lines was run in the Exile Hill area, at the proposed location for repository surface facilities (Reynolds, 1985). A total of five lines were run using a short-offset, short-spread configuration with a weight drop source and a moveable streamer-type receiver array with gimballed geophones on 66-ft stations. The array was towed by a truck that also operated the weight drop source. Signal enhancement was possible by stacking traces, but was not generally used in this survey.

A frequency-wavenumber ( $f-k$ ) filter was applied to each gather, to nominally reject events with phase velocities less than $5,000 \mathrm{~m} / \mathrm{sec}$. The records were then CDP stacked to six-fold, and datum corrections were applied using velocities derived from nearby refraction surveys. A "dip filter" was applied whereby nine adjacent traces were examined for coherency at dips up to 20 degrees. Events identified as coherent were added at mean amplitude back to unfiltered data at the position of the central trace of the nine (Reynolds, 1985).

Some of the reported results are discussed here for perspective on the survey. The dip slip offset of the Bow Ridge fault in the vicinity of Trench 14 was estimated to be 250 to $300 \mathrm{ft}$. Variations in apparent velocity indicate that the valley east of Exile Hill may be composed of a number of small faulted blocks, filled in by alluvium. Low velocity, possibly associated with fracturing and weathering, was found to be more prevalent on 
the east side of Exile Hill than to the west. These conclusions are consistent with, and correspond to, the known geology of the location.

The Exile Hill survey raises a number of questions that are relevant to future use of the method, and possibly to future exploration at this location. Low velocities such as those observed are often associated with severe attenuation. However, coherent reflections were reported with travel times up to 1 sec corresponding to reflector depth of 1,500 ft or more. Frequency-wavenumber filtering can introduce artificial lineups, as mentioned in the report (Reynolds, 1985), as shown for random noise by Howard and Danbom (1983), and as discussed by Serpa et al. (1988). The use of $f-k$ filtering may have produced artifacts because of clipping and spatial aliasing. Refraction data and downhole velocity surveys showed the shear wave velocity to be on the order of 400 to $550 \mathrm{~m} / \mathrm{sec}$, which was the approximate phase velocity of ground roll. With receiver spacing of $20 \mathrm{~m}$ and source band of roughly 20 to $60 \mathrm{~Hz}$, the ground roll wavelength range of 6 to $25 \mathrm{~m}$ was inadequately sampled for $\mathrm{f}-\mathrm{k}$ filtering. As pointed out by tones et al. (1987), f-k filtering can provide significant noise rejection, but introduces stringent conditions on data quality and sampling. The nonlinear dip filter used subsequent to $f-k$ filtering (Reynolds, 1985) probably accentuated the artifacts caused by aliasing.

\section{SUMMARY OF RESULTS (Shallow, High-Resolution Reflection Profiling)}

Experience gained in acquiring, processing, and interpreting highresolution reflection data in southern Nevada, particularly using the Mini-Sosie method, is judged to be applicable to site characterization. Improvement has been obtained by grouping geophones in clusters, and by processing in the field for adjustment of acquisition parameters.

For future fault detection and characterization work, the Mini-Sosie investigator (Harding, in USGS, 1988) recommends multiple lines in network configuration, rather than single profiles. Accordingly, additional lines would be run across the Windy Wash fault in Crater Flat, and at the mouth of Tarantula Canyon, to substantiate the existing interpretations. Satisfactory high-resolution reflection data can probably be acquired from some areas of Crater Flat, but there are areas where the alluvial cover is too deep, or the volcanic bedrock too irregular for interpretable profiling by shallow reflection methods.

The sumary report on the 1980,1981 , and 1982 reflection surveys (McGovern, 1983) recommends against "...any additional reflection surveys in the Yucca Mountain complex" on the basis of the work described above. The report discounts the 1980 and 1981 surveys because the designs were limited and clearly vulnerable to noise. The negative conclusion is thus based principally on the 1982 survey. However, the 1982 survey was also limited, and the results very likely do not represent all methods available for seismic reflection exploration. Additional discussion of the merits of the 1982 survey is presented in Section 3.1 of this paper.

Though the shear wave tests were not extensive, they indicate that shallow-penetrating shear wave techniques may be effective in the tuff 
sequence, despite the inixed results obtained with more conventional survey methods, using explosive and vibrator sources. The shallow reflection lines in the vicinity of Exile Hill produced some useful results (e.g., velocities); however, the presence of artifacts in the processed reflection sections is likely.

\subsubsection{INTERMEDIATE-DEPTH REFLECTION SURVEYS}

\section{OBJECTIVES}

This category includes surveys where the two-way acquisition window extends to roughly $5 \mathrm{sec}(+/-)$, and target structures lie between about 0.3 and $10 \mathrm{~km}$ depth. Historically, this type of survey has been used mostly for resource exploration in sedimentary terranes. Structural features that represent the tectonic setting of Yucca Mountain are likely to be found in this depth range. Older features (not necessarily inactive) in the Yucca Mountain site area may be found below the Tertiary volcanics. Intermediatedepth methods are more specific to the site area relative to surrounding areas, and thus may be useful for assessing the relation of deeper structure to shallower, more easily recognizable features of which the effects on site performance are better understood.

The clarity of interpretation that can result from intermediate-depth seismic reflection in certain geologic settings is preferable to that which is typically obtained from other geophysical methods. Clarity is important for investigation of such complex topics as the origin of Crater Flat, and the conformation of the Paleozoic-Tertiary contact beneath Yucca Mountain.

\section{DATA COVERAGE AND QUALITY (Intermediate-Depth Reflection Surveys)}

A significant number of intermediate-depth $(0-5 \mathrm{sec})$ lines has been acquired regionally, especially to the southeast of Yucca Mountain (Figure 2.5-2). These surveys have used shallow explosive, Vibroseis, and land air-gun sources. The quality of the data is variable, and reflects the care with which the surveys were designed and conducted. As shown in the figure, an extensive grid of lines has been run in the Pahrump Valley, west of Las Vegas. This grid is aligned with the strike of major structures such as the Las Vegas shear zone, the Spring Mountains, and Death Valley. Additional lines have been run across the Las Vegas valley and the Spring Mountains, and a northwest trending line has been run following the Las Vegas shear zone. The area has been considered for oil and gas exploration because thick Paleozoic carbonate rocks have been thrust over Mesozoic sandstone and shale. The data are proprietary and have not been reviewed by the Yucca Mountain Project. However, the total number of lines suggests that the quality of the data favors useful interpretation. Efforts will be made to obtain access to these data for review and possible acquisition, and for possible application of the same methods closer to the site.

A number of reflection lines have been run on the NTS in support of weapons testing programs (see Table 2.5-1). These include a network of lines 


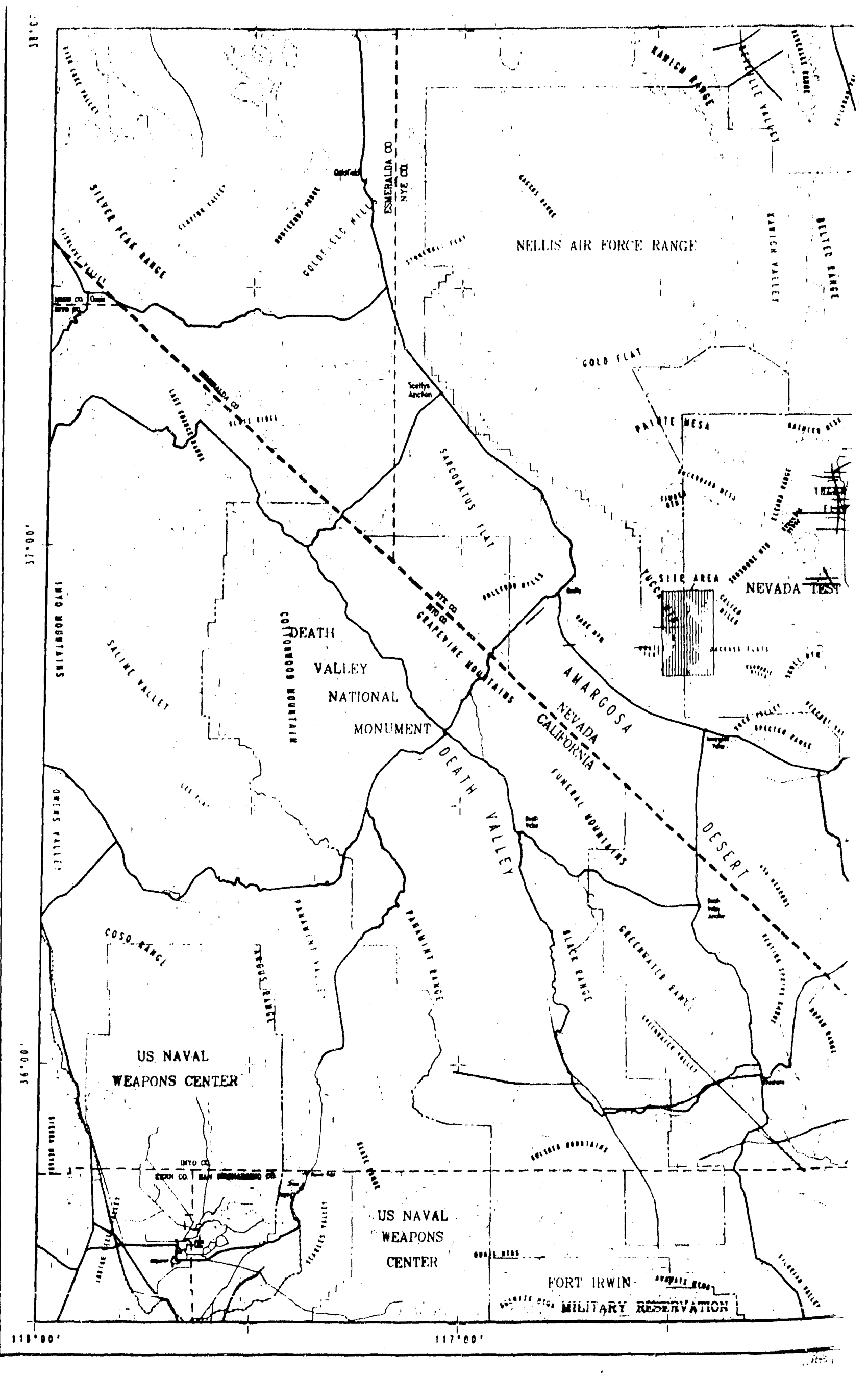


in Yucca Flat (Figure 2.5-2), lines in Frenchman Flat, and three lines in Mid Valley. The geology of Yucca Flat differs somewhat from the Yucca Mountain site area, and consists of tuffaceous and mixed alluvium (originating from Cenozoic and Paleozoic deposits) overlying tuffs, and upper Paleozoic clastics and carbonates over a large area. Velocity structure at Yucca Flat and Frenchman Flat differs significantly from conditions in the Yucca Mountain site area. However, methodological and interpretive findings from reflection profiling in these areas may be applicable to exploration of areas adjacent to Yucca Mountain, such as Jackass Flats.

Strong reflections from the upper 2 to $3 \mathrm{~km}$ can be readily obtained in Yucca Flat and Frenchman Flat, where there is excellent borehole control for use in interpretation and data processing. Impedance contrast suitable for mappable reflections is typically observed at the tuffaceous alluvium-mixed alluvium contact, and the Paleozoic-Tertiary contact. The tuffaceous alluvium/tuff contact is not generally a mappable reflector, nor is the mixed alluvium/Paleozoic contact. In addition some of the vitrophyres in the tuff section can be mapped as reflectors. Borehole control in Yucca Flat has provided a water table database which confirms that the water table is not a mappable reflector. Much of the seismic data for these areas on the NTS are unclassified, but the data sections, the details of acquisition, seismic interpretation, and integration with other geophysical and geological data have not been published (N. Burkhard, personal communication, 1989).

Another survey run for the weapons-related program on the NTS consisted of three intersecting reflection lines, and two exploratory boreholes, in the southern part of Mid Valley (McArthur and Burkhard, 1986). A total of $18 \mathrm{~km}$ of profiling was done using a land air-gun source for the first time on the NTS. The survey lines were designed based on gravity data, to better characterize the target area with minimal effort. The lines were located so as to pass near the boreholes. A linear source-receiver array was used for each line, with 48-fold CDP coverage and $25 \mathrm{~m}$ group separation.

Several coherent events were found, allowing interpretation of the tuff-alluvium contact, the basal member of the Timber Mountain Tuff, and the Thirsty Canyon Tuff embedded in the alluvium (McArthur and Burkhard, 1986). Lithologic work on drill core from the calibrating boreholes, in conjunction with downhole geophone surveys, provided the basis for stratigraphic interpretation of the seismic profiles. In addition the Paleozoic-Tertiary contact, and structure deeper in the section (possibly a subhorizontal detachment), were inferred. Various faults were observed, and were fully consistent with reasonable geologic interpretations for the formation of Mid Valley. Little or no evidence for listric faults was observed down to at least 1.5 sec two-way travel time.

A high-quality, east-west reflection line was recently acquired by the USGS south of Lathrop Wells, to evaluate methods for deep, regional crustal exploration (Brocher et al., 1989). Although the survey was conducted primarily to test methods for deep, regional profiling as described below, extensive information was also obtained from intermediate-depth. Vibrator and explosive sources were compared using in-line source-receiver geometry. The dynamite and vibrator-source sections are similar in the first $5 \mathrm{sec}$, with good to excellent reflections (Brocher and Hart, 1988). Numerous fault b.locks are well-delineated, and intrabasin reflections are common. 
When data are appropriately collected, the reflection method has apparently revealed the crystalline basement, reflections from the tuff-alluvium contact, reflections from various tuff units, and the Paleozoic-Tertiary contact. The Amargosa Valley test line (Brocher et al., 1989) shows that methods based on both vibrator and explosive sources can provide useful intermediate-depth inforluation in a geologic setting that is comparable to, although not the same as, the site area. (Further improvement might be obtained by adjusting survey parameters to optimize response from intermediate depth features.) The Mid Valley survey (McArthur and Burkhard, 1986) and the Amargosa Valley test line will be further examined as described in Site Characterization Plan Activity 8.3.1.17.4.7.1 (Evaluate intermediate-depth reflection and refraction methods and plan potential application of these methods within the site area). Reflection profiling for the weapons testing program on the NTS has been extensive and successful, and aspects of the geologic setting in these areas are similar to areas in the vicinity of Yucca Mountain. Information on the acquisition and interpretation of these profiles is accessible and will be incorporated into Project activities to the extent practicable.

A fundamental obstacle to the imaging of subsurface structure at intermediate-depth is that travel times for reflected events correspond to travel times for the strongest noise. Available data and interpretation indicate that useful intermediate-depth reflection data can be obtained for the Yucca Mountain site area through exercise of appropriate controls, notwithstanding the past negative results described above in the section on shallow high-resolution profiling. Appropriate controls include choice of sources (including sources with sufficient power); orientation of lines with respect to the fabric of the tectonic setting; location of the lines with respect to complex structure, particularly off-axis structure; survey design in conjunction with gravity and magnetic interpretations; attention to statics and the near-surface velocity structure, whereby travel time correction uncertainty is reduced to acceptable levels; use of existing or future boreholes for calibration of the reflection response; and use of downhole geophone surveys for advance estimation of seismic response.

\subsubsection{DEEP REFLECTION PROFILES}

\section{OBJECTIVES}

Extensive deep, regional reflection profiling has been undertaken by the COCORP (Consortium for Continental Reflection Profiling), supported mostly by the National Science Foundation. General objectives of this profiling are to further understand the tectonic setting of major geologic provinces, to identify and delineate active processes, and evaluate alternate tectonic. models. More specific objectives include investigation of (1) subsurface geometry of major faults; (2) possible concealed features such as mid-crustal detachments or magma bodies; (3) the relation of surface mapped faults to concealed features; (4) variations in the seismic basement and transitions in Moho depth; (5) deep subsurface conditions associated with prominent potential field anomalies; (6) structural differences across boundaries 
between crustal provinces; and (7) paleotectonic history of the continent, and the influence of pre-Tertiary structure on active processes.

\section{DATA COVERAGE AND QUALITY (Deep Reflection Profiles)}

About $250 \mathrm{~km}$ of deep, regional reflection profiles have been acquired by COCORP in the Mojave Desert and Death Valley (Serpa et al., 1988; deVoogd et al., 1986). The COCORP Death Valley Survey consisted of five intersecting profiles, as shown in Figure 2.5-2. Other COCORP profiles in adjacent areas include an east-north-east trending transect across central Arizona (Hauser et al., 1987) and a series of connected east-west lines across Nevada at about $40^{\circ} \mathrm{N}$ (overview by Allmendinger et al., 1987).

COCORP data have typically been acquired using Vibroseis sources, with offsets up to $10 \mathrm{~km}$, and receiver arrays designed according to noise conditions. The lines referenced above were run with in-line spreads. Most have used continuous profiling with high-fold CDP coverage; off-end configurations were used for the Death Valley lines (Serpa et al., 1987), resulting in lower-fold but fewer source stations. COCORP profiles are typically acquired with a sampling interval of 4 to $8 \mathrm{msec}$, recording window of 0 to $15 \mathrm{sec}, 8$ to $32 \mathrm{~Hz}$ sweep, and up to 8 sweeps stacked per source station. Processing steps are designed to avoid artificial events (Serpa et al., 1987; Allmendinger et al., 1987), and may sacrifice high-frequency content for interpretability consistent with the deep profiling objectives. The use of velocity $(f-k)$ filtering has been investigated for many sections (Allmendinger et al., 1987), but is usually not used for the final section. Where coherence is a problem or higher resolution is needed, single-source, single-fold, near-vertical incidence sections have been generated (deVoogd et al., 1986; Klemperer et al., 1986). Data quality of the COCORP profiles could probably be increased by more attention to testing of acquisition parameters, and characterization of noise sources in the field.

COCORP lines in the Yucca Mountain region, including the profile at $40^{\circ} \mathrm{N}$ (about $300 \mathrm{~km}$ north of Yucca Mountain), have contributed significantly to understanding of the tectonic provinces and paleotectonic history of western North America. Previously unknown crustal features have been detected such as (1) the possible feeder dike structure associated with the wingate Wash fault in southern Death Valley (deVoogd et al., 1986; Serpa et al., 1988), which supports a new interpretation of laterally continuous, mid-crustal reflections as active or cooled magmatic intrusions; and (2) an offset in the reflection Moho at the transition between the Basin and Range, and the Colorado plateau (Hauser et al., 1987). Association of mid-crustal reflections with models for deep detachment surfaces supports the reinterpretation of structures that had previously been inferred from surface observations. The nature of the reflection Moho correlates with the morphology of the Basin and Range, and is most poorly expressed where low-angle normal tallts are best developed in the mid-crust (Allmendinger et al., 1987).

There are two factors that probably contribute to the success of the COCORP surveys. The lines have been carefully located and oriented with respect to target structures, and structures that could interfere with deep 
profiling. In addition, off-axis scatter and surface wave noise problems are reduced for deep profiles because of the long travel time of deep

reflections, the apparent low seismic attenuation of the iniddle and lower crust, and the relatively rapid dissipation of energy confined near the surface.

A high-quality, 27-km long, east-west reflection test line was recently acquired by the USGS in the Amargosa Valley south of Yucca Mountain (Figure 2.5-2). Vibrator reflection data were acquired by continuous profiling at 60-fold, and explosive-source data were acquired in single-fold, split-spread configuration. The comparison of explosive and Vibroseis sources indicates that explosive sources in shot holes provide high-quality images of the lower crust and Moho, due to the high energy levels and better coupling to the earth. The explosive source data are more interpretable below about 5 sec two-way travel time, despite the high fold of the vibrator data. The explosive source data clearly indicate near-horizontal discontinuous (e.g., $1 \mathrm{~km}$ length) reflections below $5 \mathrm{sec}$.

Surface conditions along the Amargosa Valley line are relatively uniform, consisting of faulted blocks mostly buried by alluvium. The structure of the faulted, buried terrane is evident from the reflection profile down to about $5 \mathrm{sec}$ two-way travel time. Below this is a mid-crustal reflector at about 6 to $8 \mathrm{sec}$, which has been observed in Death Valley COCORP results (Serpa et al., 1987) and explained variously as an extensive magma body, cooled intrusions, deep detachment, or brittle-ductile crustal. transition. Abundant reflections from below this depth are less readily interpretable, but may represent detachment surfaces and major pre-Tertiary extensional or thrust faults.

A change in character below about $10 \mathrm{sec}$ vaguely suggests a demarcation such as the base of the crust, corresponding to the reflection Moho identified from COCORP profiles across central Nevada by Klemperer et al. (1986). The change is recognized principally by a lack of reflections at: greater travel times, similar to that observed by Knuepfer et al. (1987) from a COCORP profile across the Walker Lane at about $40^{\circ} \mathrm{N}$.

\section{SUMMARY OF RESULTS (Deep Reflection Profiles)}

COCORP lines have been run across the Walker Lane in west-central Nevada (Knuepfer et al., 1987), across the central Basin and Range at the 40th parallel (Alimendinger et al., 1987), and in the vicinity of Death Valley (Serpa et al., 1988). Interpretable results have been obtained from these lines, such as mapping of the reflection Moho, mapping of strong mid-crustal reflections postulated to be regional detachments (Knuepfer et al., 1987), and detection of probable features such as magma bodies and Moho offset. It is reasonable to assume that such results could be obtained on a large scale for the Yucca Mountain region, and results from reflection testing in the Amargosa Valley support this view. This topic will receive further consideration in a review planned for SCP Activity 8.3.1.17.4.3.1. 


\section{BIBLIOGRAPHY FOR SECTION 2.5}

Allmendinger, R.W., et al., 1987. Overview of the COCORP $40^{\circ} \mathrm{N}$ Transect, Western United States: The Eabric of an Orogenic Belt, Geological Society of America Bulletin, vol. 98, p. 308-319.

Barbier, M.G., 1983: The Mini-Sosie Method, International Human Resources Development Corp, Boston, Massachusetts.

Barry, C.T., 1980. A Study of the Vertical Vibrator Source for Seismic Profiling in the yucca Mountain Area of the Nevada Test Site, Master of Engineering thesis, ER 2429, Colorado School of Mines, 58 p.

Brocher, T.M., and P.E. Hart, 1988. "Direct Comparison of Dynamite and Vibroseis Methods for Deep Crustal Seismic Reflection Studies in the Southwestern Basin and Range, Nevada, USA" (poster), EOS, Transactions, American Geophysical Union, vol. 69, no. 44, p. 1313.

Brocher, T.M., P.E. Hart, and S.F. Carle, 1989. Feasibility study of the Seismic Reflection Method in Amargosa Desert, Nye County, Nevada, U.S. Geological Survey Open File Report, in preparation.

deVoogd, B., et al., 1986. "Death Valley Bright Spot: A Midcrustal Magma Body in the Southern Great Basin, California?," Geology, vol. 14, p. 64-67, January 1986.

Hasbrouck, W.P., 1987. "Hammer-Impact, Shear-Wave Studies," in Danbron, S.H., and S.N. Domenico (eds.), Shear Wave Exploration, Geophysical Development Series, vol. 2, Society of Exploration Geophysicists, p. $97-121$.

Hasbrouck, W.P., 1988. Five Shallow Seismic Feasibility Surveys, Expanded Abstracts, Society of Exploration Geophysicists, $58 \mathrm{th}$ Annual International Meeting and Exposition, Oct. 30-Nov. 3, 1988, p. 286-289.

Hauser, E.C., et al., 1987. "COCORP Arizona Transect: Strong Crustal Reflections and Offset Moho Beneath the Transition Zone," Geology, vol. 15, p. 11.03-1106.

Howard, M.S., and S.H. Danbom, 1983. "Random Noise Exarnple," in Bailey, A.W. (ed.), Seismic Expressions of Structural Styles, Vol. I, American Association of Petroleum Geologists Studies in Geology, ser. 15, p. 25.

Klemperer, S.I., T.A. Hauge, E.C. Hauser, J.E. Oliver, and C.J. Potter, 1986. The Moho in the Northern Basin and Range Province, Nevada, Along the COCORP $40^{\circ} \mathrm{N}$ Seismic Reflection Transect, Geological Society of America Bulletin, vol. 97, p. 603-618.

Knuepfer, P.L.K., et al., 1987. Crustal Structure of the Basin and Range-Sierra Nevada Transition from COCORP Deep Seismic-Reflection Profiling, Geological Society of America Bulletin, vol, 98, p. 488-496. 
McArthur, R.D., and N.R. Burkhard, 1986. Geological and Geophysical Investigations of Mid Valley, Lawrence Livermore National Laboratory, UCID-20740, $92 \mathrm{p}$.

McGovern, T.E., L.W. Pankratz, and H.D. Ackermann, 1983. An Evaluation of Seismic Reflection Studies in the Yucca Mountain Area, Nevada Test Site, U.S. Geological Survey Open File Report 83-912, 57 p.

Serpa, I., B. de Voogd, L. Wright, J. Willemin, J. Oliver, E. Hauser, and B. Troxel, 1988. Structure of the Central Death Valley Pull-Apart Basin from COCORP profiles in the Southern Great Basin, Geological Society of America Bulletin, vol. 100, p. 1437-1450.

USGS (U.S. Geological Survey), 1988. Geologic and Hydrologic Investigations of a Potential Nuclear Waste Disposal Site at Yucca Mov rtain, Southern Nevada, M.D. Carr and J.C.. Yount (eds.), U.S. Geologica.: Survey Bullet in 1790, 152 p. 


\subsection{REMOTE SENSING AND MERIAL GAMMA-RAY SURVEYS}

This section addresses the two topics separately; each topic is followed by its own bibliography.

\subsubsection{REMOTE SENSING}

OBJE ITIVES

Renote sensing techniques are based on airborne or satellite-based imaging $0_{:}^{:}$: : surface, at elec:romagnetic frequency levels ranging from gamma ray. jugh the visible, and thermal infrared to radio frequencies. Digital image data are acquired and processed by computer into various data sets, including synthetic-aperture radar image mosaics for geomorphic and structural mapping, and Landsat Multispectral scanner (MSS) and thematic mapper images for spectral discrimination for lithologic mapping. Major objectives for the use of remote sensing in the Yucca Mountain Project are (1) characterization of surface hydrology, (2) exploration for indications of nydrothermal mineralization, and (3) fracture-pattern mapping for structural and tectonic studies.

\section{DATA COVERAGE AND QUALITY}

A list of currently available remote sensing data and interpretive work of different types, applicable to studies of the Yucca Mountain region, follows. The text refers to map quadrangles which correspond to the generally available, $1^{\circ} \times 2^{\circ}$ series of maps at $1: 250,000$ distributed by the USGS.

1. The USGS Remote Sensing Tape Iibrary (item 36 of bibliography) includes a complete set of digital tapes of all spectrai bands of the Landsat MSS coverage of Nevada. The digital tapes are of high quality with little or no cloud cover for most of the State. Concatenation and Applicon or Calcomp printing of MSS scenes for four $2^{\circ}$ quadrangles at 1:250,000 (Caliente, Las Vegas, Death Valley, and Goldfield) constitute a database suitable for spectral band ratioing for research purposes.

2. The USGS Remote Sensing Tape Library also includes a complete set of digital Landsat Thematic Mapper (TM) tapes of the four quadringles listed above, c.rsisting of six scenes, mostly cloud free an, of good quality. Thuy are suitable for concatenation to fit selected quadrangles at scales greater than $1: 250,000$ (e.g., suitable for fitting the Beatty quadrangle at $1: 100,000$ or greater). Concomitant sprctral band-ratio technigies are available for ...e TM data sets.

3. Selected airborne therr-. I infrared and multispectral (TiMS) data are available for a very few selected areas within the state and could be useful. See items (6) (Osgood Mountains), and (10) and (18) (Carlin distiict) from the bibliography; good volcanic terrain data 
are available; see (18) for the El Dorado Mountains southeast of Las Vegas.

4. Publications on the occurrences of limonitic surface materials and, in places, their relationship to thermal and hydrothernat alteration zones, include iteme (1), (5), (8), (9), (19), (20), (22), (23), $(26),(27),(28),(30)$, and (34) of the Dibliography. Many of these items cover the Walker Lake $2^{\circ}$ quadrangle. A composite map of the occurrences of limonitic surface materials displayed on a Landsat MSS mosaic for the entire State of Nevada, without discrimination as to genesis of the iron-oxide bearing surfaces, has been completed as a map data set and printed experimentally, but has not yet been published.

5. Publications on lineamentation, and more specifically on fracturepattern analyses and their relationship to geologic structure and mineralization, include items (13), (14), (15), (16), (17), (23), (29), (32), and (33) of the bibliography.

6. Publications dealing with spectral discrimination of rock types and related topics include items (1), (2), (3), (4), (5), (7), (8), (9), (10), (18), (19), (20), (21), (22), and (34) of the bibliography.

7. Publications on remote sensing technology and computer techniques include items (11), (12), (24), (25), and (35) of the bibliography.

8. Complete synthetic aperture radar (SAR) mosaics are available through the USGS Branch of Geophysics for the Caliente and Las Vegas $2^{\circ}$ quadrangles at 1:250,000 with the exception of classified areas. The mosaics are fitted to USGS map bases at $1: 250,000$ and are of high clarity; they are of exceptional value in geomorphic and structural mapping. Although slant-to-ground range corrections have been made, radar shadows and la. over problems remain in areas of high relief.

\section{SUMMARY OF RESULTS}

The following materials and data sets, currently available to the Branch of Geophysics, are suitable for interpretative investigations of the Yucca Mountain region.

1. Complete coverage of all spectral bands of MSS coverage of the entire region, suitable for concatenation, spectral band ratioing, and discrimination of iron-oxide surface materials at scales of 1:500,000 with clear detail, and at 1:250,000 at the margin of good resolution.

2. TM coverage of the entire region, with spatial resolution at two times that of the MSS coverage (hence well-suited for geologic mapping and fracture pattern investigations, as well as spectral discrimination of desert varnish surfaces). 
3. Elightline radar (SAR) data tapes for a].1 four $2^{\circ} 1: 250,000$ quadrangles: Caliente, Las Vegas, Death Valley, and Goldfield. Synthetic aperture radar mosaics are available for the Las vegas quadrangle, and can be concatenated for the Caliente quadrangle. The mosaics are not yet available for Death Valley and Goldfield quadrangles.

Digital multispectral and stereo coverage tapes exist for at least the Yucca Mountain regions; their acquisition by the Yucca Mountain remote sensing project would entail expenditures of more than $\$ 10,000$. Small areal coverage of airborne thermal infrared coverage exists, but the acquisition of new thermal infrared coverage is best if carefully planned and integrated with ground control and experimentation (e.g., aerial IR coverage could be suitable for mappinct areas of infiltration and discharge if it is acquired during night or very early morning hours within a few hours after a sizable rainfall event).

Interpretative studies already published are cited in the bibliography.

BIBLIOGRAPHY FOR SECTION 2.6 .1

1. Abrams, M.J., K.P. Ashley, I.C. Rowan, A.F.H. Goetz and A.B. Kahle, 1977. "Mapping of Hydrothermal Alteration in the Cuprite Mining District, Nevada, Using Aircraft Scanner Images for the Spectral Region 0.46 to $2.36 \mathrm{~m}, "$ Geology, val. 5, no. 12, p. 713-718.

2. Bailey, G.B., J.I. Dwyer, and M.H. Podwysocki, 1985. "Evaluation of Landsat Thematic Mapper Data for Geologic Napping in Semi-Arid Terrains," in International Symposium on Remote Sensing of Environment, Thematic Conference on Remote Sensing for Exploration Geology, 4th, Colorado, 1285, Proceedings, Ann Arbor, Michigan, Environmental Research Institute of Michigan, p. 781-782.

3. Brickey, D.W., 1987. "The Use of Thematic Mapper Imagery for Mineral Exploration in the Sedimentary Terrane of the Spring Mountains, Nevada," in International Symposium on Remote Sensing of Environment, Thematic Conference on Remote Sensing for Exploration Geology, 5th, Reno, Nevada, Sept. 29-Oct. 2, 1986, Proceedings, Ann Arbor, Michigan, Environmental Research Institute of Michigan, p. 607-613.

4. Hunt, G.R., 1979. Spectra of Rocks and Soils from the Eastern Shoshone Range, Nevada, U.S. Geological Survey Open File Report 79-707, 4 p.

5. Knepper, D.H., Jr., 1988. "Distribution of Exposed Limonitic Rocks and Soils from Landsat Multispectra]. Scanner Data on the Southern Ute Indian Reservation, Southwestern Colorado, $"$ in Fassett, J.E. (ed.), Geology and Coal-Ped Methane Resources of the Northern. San Juan Basin, Colorado and New Mexico, Rocky Mountain Association of Geologists Guidebook, p. 295-296. 
6. Krohn, M.D., 1984. "Interpretation of Thermal-Infrared Multispectral Scanner (TIMS) Images of the Osgood Mountains, Nevada," in International Symposium on Remote Sensing of Environment, Thematic Conference on Remote Sensing for Exploration Geology, Colorado Springs, Colorado, April 16-19, 1984, Proceedings (ext. abs.), Ann Arbor, Michigan, Environmental Research Institute of Michigan, vol. 2, p. 735-737.

7. Krohn, M.D., 1986, "Spectral Properties (0.4 to 25 microns) of Selected Rocks Associated with Disseminated Gold and Silver Deposits in Nevada and Idaho," Journal of Geophysical Research, B. 91, p. 767-783.

8. Krohn, M.D., M.J. Abrams, and L.C. Rowan, 1978. Discrimination of Hydrothermally Altered Rocks Along the Battle Mountain-Eureka, Nevada, Mineral Belt Using Landsat Images, U.S. Geological Survey Open File Report $78-585,63 \mathrm{p}$.

9. Kruse, F.A., 1986. "Digital Mapping of Alteration Zones in a Hydrothermal System Using Landsat Thematic Mapper Data -- An example from the Northern Grapevine Mountains, Nevada/California," in International Symposium on Remote Sensing of Environment, Thematic Conference on Remote Sensing for Exploration Geology, 5th, Reno, Nevada, Sept. 29-Oct. 2, 1986, Summaries, Ann Arbor, Michigan, Environmental Research Institute of Michigan, p. 51.

10. Kruse, F.A., S. Hummer-Miller, and K. Watson, 1987. Thermal Infrared Remote Sensing of the Carlin Disseminated Gold Deposit, Eureka County, Nevada, Symposium on Bulk Mineable Precious Metal Deposits of the Western United States, Sparks, Nevada, April 6-8.

11. Kruse, F.A., and G.L. Raines, 1984. "A Technique for Enhancing Digital Color Images by Contrast Stretching in Munsell Color Space," in International Symposium on Remote Sensing of Environment, Thematic Conference on Remote Sensing for Exploration Geology, 3d, Colorado, 1984, Proceedings, Ann Arbor, Michigan, Environmental Research Institute of Michigan, vol. 2, p. 755-760.

12. Niblack, W., 1981. Control Point Library Building System, Photogrammetric Engineering and Remote Sensing, vol. 47, no. 12, p. $1709-1750$.

13. O'Leary, D.W., and J.D. Friedman, 1981. "Toward a Workable Lineament Symbology," in O'Leary, D.W., and J.L. Earle (eds.), International Conference on Basement Tectonics, 3d, Proceedings, Denver, Colorado, Basement Tectonics committee, Publication 3, p. 29-31.

14. O'Leary, D.W., J.D. Friedman, and H.A Pohn, 1976. Iineament, Linear, Lineation--Some Proposed New Standards for old Terms, Geological Society of America Bulletin, vol. 87, p. 1463-1469.

15. O'Leary, D.W., J.D. Friedman, and H.A. Pohn, 1976. Lineament, Linear, Lineation--Some Proposed New Standards for Old Terms: Discussion and Reply, Geological Society of America Bulletin, vol. 88, p. 159-160. 
16. O'Leary, D.W., J.D. Friedman, and H.A. Pohn, 1979. "Lineament and Linear, A Terminological Reappraisal," in 2d International Conference on Basement Tectonics, Proceedings, Basement Tectonics Committee, Denver, Colorado, p. 571-576, 22 ref.

17. O'Leary; D.W., and H.A. Pohn, 1978. A Photogeologic Comparison of Skylab and Landsat Images of Southwestern Nevada and Southeastern California, National Technical Information Service N76 20598/LI.

18. Podwysocki, M.H., W.J. Ehmann, and D.W. Brickey, 1987. "Application of Combined Landsat Thematic Mapper and Airborne Thermal Infrared Multispectral Scanner Data to Lithologic Mapping in Nevada," in International Symposium on the Remote Sensing of Environment, 21st, Ann Arbor, Michigan, Oct. 26-30, Summaries (abs.), Environmental Research Institute of Michigan, p. 20.

19. Podwysocki, M.H., M.S. Power, J.W. Salisbury, and O.D. Jones, 1984. "Evaluation of Low-Sun Illuminated Landsat-4 Thematic Mapper Data for Mapping Hydrothermally Altered Rocks in Southern Nevada," in International Symposium on Remote Sensing of Environment, Thematic Conference on Remote Sensing for kxploration Geology, 3d, Proceedings, Ann Arbor, Michigan, Environmental Research Institute of Michigan, vol. 2 , p. 541-551.

20. Purdy, T.L., G.B. Bailey, and J.L. Dwyer, 1984. "Alteration and Geologic Mapping South-Central Nevada Using Thematic Mapper Data, " in International Symposium on Remote Sensing of Environment, Thematic Conference on Remote Sensing for Exploration Geology, 4th, San Francisco, California, 1985, Proceedings (abs.), Ann Arbor, Michigan, Environmental Research Institute of Michigan.

21. Purdy, T.I., G.B. Bailey, and J.L. Dwyer, 1985. Landsat Multispectral Scanner and Landsat Thematic Mapper Images and Interpretations of Hannapah and Royston Hills, Nevada, U.S. Geological Survey Open File Report 85-461, 3 p., 21 slides.

22. Purdy, T.I., G.F. Brem, and W.E. Collins, 1984. Use of High-Spectral Resolution Airborne Spectroradiometer Data to Map Hydrothermally Altered Rocks in the Gabbs Valley Range, Nevada, U.S. Geological Survey Open File Report 84-563, 8 p.

23. Purdy, T.I. and I.C. Rowan, 1985. "Map Showing Distribution of Altered Rocks, Faults, and Linear Features in the Walker Lake $1^{\circ} \times 2^{\circ}$ Quadrangle, Nevada and California," U.S. Geological Survey Miscellaneous Investigation Map I-1643.

24. Raines, G.I., 1977. "Digital Color Analysis of Color-Ratio Composite Landsat Scenes," in International Symposium on Remote Sensing of Environment, 11th, Proceedings, Ann Arbor, Michigan, Environmental Research Institute of Michigan, p. 1463-1472.

25. Robinove, C.T., 1982. "Computation with Physical Values from Landsat Digital Data," Photogrametric Engineering and Remote Sensing, vol. 48, no. 5 , p. $781-7 \overline{84}$. 
26. Rowan, I.C., M.D. Krohn, and T.I. Purdy, 1980. Generalized Map of Occurrences of Limonitic Rocks in the Walker Lake $1^{\circ}$ by $2^{\circ}$ Quadrangle, Nevada-California, U.S. Geological Survey Open File Report 80-232, scale $1: 250,000$.

27. Rowan, L.C., and T.I. Purdy, 1980. Preliminary Map Showing Distribution of Altered Rocks and Limonitic Unaltered Rocks in the Walker Lake $1^{\circ} \mathrm{x}$ 20 Quadrangle, Nevada-California, U.S. Geological Survey Open File Report 80-931, sct $16: 250,000$.

28. Rowan, L.C., and T.t. Purdy, 1981. "Definition of Alteration Belts in the Walker Lake, Nevada-California $1^{\circ} \times 2^{\circ}$ Quadrangle (Sumary), $"$ in International Geoscience and Remote Sensing Symposium Digest, Institute of Electrical and Electronics Engineers, vol. 1, p. 325-330.

29. Rowan, I.C., and T.I. Purdy, 1984. "Map of the Walker Lake $1^{\circ} \times 2^{\circ}$ Quadrangle, California and Nevada, showing the Regional Distribution of Iinear Features," U.S. Geological survey Miscellaneous Field Studies Map MF-1382-p, $22 \mathrm{p}$. text, scale 1:250,000.

30. Rowan, L.C., and T.I. Purdy, 1984. "Map of the Walker Lake $1^{\circ} x 2^{\circ}$ Quadrangle, California and Nevada, Showing the Regional Distribution of Hydrothermally Altered Rocks," U.S. Geological Survey Miscellaneous Field Studies Map MF-1382-Q, $19 \mathrm{p}$. text, scale 1:250,000.

31. Rowan, I.C., and P.H. Wetlaufer, 1973. "Structural Geologic Analysis for Nevada Using ERTS-1 Images: A Preliminary Report," in Symposium on Significant Results Obtained from Earth Resources Technology Satellite-1, Proceedings, National Aeronautics and Space Administration, NASA SP-327, vol. 1, sec. A, p. 413-424.

32. Rowan, L.C., and P.H. Wetlaufer, 1979. Geologic Evaluation of Major Landsat Lineaments in Nevada and Their Relationship to Ore Deposits, U.S. Geological Survey Open File Report 79-544, 87 p.

33. Rowan, L.C., and P.H. Wetlaufer, 1981. "Relationship Between Regional Lineament System and Structural zones in Nevada," American Association of Petroleum Geologists, vol. 65, no. 8, p. 1414-1432.

34. Rowan, L.C., P.H. Wetlaufer, A.F.H. Goetz, F.C. Billingsley and J.H. Stewart, 1974. Discrimination of Rock Types and Detection of Hydrothermally AItered Areas in South-Central Nevada by the Use of Computer-Enhanced ERTS Images, U.S. Geological Survey Pxofessional paper $883,35 \mathrm{p}$.

35. Sawatzky, D.I., 1985. Programmer's Guide to REMAPP, Remoce Sensing Array Processing Procedures, U.S. Geological Survey Open File Report 85-231, 16 p.

36. USGS (U.S. Geological Survey). Geophysics Remote Sensing Tape Library, U.S. Geological Survey, Branch of Geophysics, Denver, Colorado. 


\subsubsection{AERIAL GAMMA-RAY SURVEYS OVER THE NEVADA TEST SITE}

\section{OBJECTIVES}

Aerial and ground gamma-ray surveys measure the gamma radiation emitted by radioisotopes at and near the surface of the ground. The measurements are sensitive to radioisotopes that result from natural processes, primarily members of the uranium-238 decay series, thorium-232 decay series, and potassium-40, and to radioisotopes such as cesium-137 and cobalt-60 that result from nuclear activities. The distribution of natural radioisotopes reflects the geologic processes that formed that distribution and thereby enables the use of natural gamma-ray measurements in geologic mapping and mineral exploration. The distribution of artificial radioisotopes reflects the activities that formed them and the weather that controlled their distribution. Major objectives for the use of aerial and ground gamma-ray measurements with the Yucca Mountain Project are (1) preparation of natural radioelement (uranium, potassium, and thorium) maps from the existing USGS-DOE database; (2) map interpretation to determine their geologic content, including detection of fault traces where radon-222 anomalies may occur and detection of areas of hydrothermal alteration; (3) selective ground measurements with a portable quantitatively calibrated spectrometer at sites determined from interpretation of the aerial data; and (4) acquisition of aerial gamma-ray data concurrent with aeromagnetic surveying for selected areas where natural radioactivity targets are known to exist. Concealed faults may be revealed in natural gamma-ray data by the detection of lithologic discontinuities and by anomalous radon-222 occurring at the surface.

\section{DATA COVERAGE AND QUALITY}

From about 1955 through the Sedan tests of 1962, the USGS operated a total count gamma-ray system in aerial surveillance of Atomic Energy Commission (AEC) nuclear activities on the NTS. Results of the surveys were quickiy supplied to AEC personnel by means of informal written communications and no formal publications or even open file reports were prepared. Davis and Reinhardt (items 3 and 4 in the bibliography) discuss the USGS total count system and calibration. EG\&G began aerial surveillance of NTS nuclear activities in the early 1960's (items 1, 5, and 18), and continues today.

The DOE during 1974 to 1981 accumplished the National Uranium Resource Evaluation (NURE) program for the conterminous 48 states and Alaska, which included aerial gamma-ray spectrometry surveying for uranium exploration. The surveying was keyed to the National Topographic Map Series (N.MS) $1^{\circ} \times 2^{\circ}$ quadrangles. Flightiline spacing varied from 1 to 6 miles $(1.6$ to $9.5 \mathrm{~km})$, dependent on known or probable occurrences of uranium mineralization. Of the four NTMS quadrangles that include the NTS, the Death Valley quadrangle (item 6) has 1 -mile $(1.6-\mathrm{km})$ spaced north-south flightlines (and includes the Project), and the Caliente (item 9), Goldfield (item 7), and Las Vegas (item 8) quadrangles have 3 -mile $(4.8-\mathrm{km})$ spaced east-west flightlines, excluding the southwest quarter of the Caliente quadrangle. 
The USGS has compiled all NURE gamma-ray data for the lower 48 states into a database that includes flightline and $3 \mathrm{~km}$ grid values for the apparent surface concentrations of uranium, potassium, and thorium. The conversion of aerial gamma-ray measurements to radioelement concentrations is enabled by calibration of aerial survey systems at sites of known radioelement concentrations (items 15,17 , and 26). The database permits map preparation for any feature that has geographic definition. Maps prepared to date include those for Nevada (item 11), New Mexico (items 12 and 13), Ohio (item 10), and Arizona (item 22). For this study flightline data from the USGS database would be used to prepare radioelement maps for the NTS area at $1.5-\mathrm{mile}(2.4-\mathrm{km})$ grid cell size and for the Project area at $0.5-\mathrm{mile}$ $(0.8-\mathrm{km})$ grid cell size. Interpretation of maps for Nevada made from the database is discussed by (item 14).

The helicopter gamma-ray spectrometer system used by EG\&G for NTS nuclear surveiliance acquires spectral data with artificial anc natural radioisotope components. These complex spectra are readily separated and reduced by digital computer. Repeat surveys to monitor leakage or other contamination at a repository site would supply data that would be used to determine whether atmospheric pressure-induced radon anomalies occur along faults in the vicinity of Yucca Mountain.

Aerial gamma-ray measurements have been used in geologic studies as described by Darnley (item 2) and Pitkin (item 21), and in mineral exploration as described by Gnojek and Prichystal (item 16), Killeen (item 19), and Yeates and others (item 25). Ground follow-up of aerial surveys is described by Pitkin and Huffman (items 23 and 24), and calibration of portable spectrometers for ground surveys is described by Grasty and Darnley (item 17) and Lovberg and Mose (item 20).

\section{SUMMARY OF RESULTS}

Airborne gamma ray data collected by the NURE project, and for NTS nuclear surveillance, are available over Yucca Mountain and surrounding areas. These data should be examined to determine their geologic content and to determine locations for ground surveys if warranted.

\section{BIBLIOGRAPHY FOR SECTION 2.6 .2}

1. Burson, Z.G., 1974. Research Progress in Airborne Surveys of Terrestrial Gamma Radiation, Workshop on Environmental Radiation, USAEC HASL, New York.

2. Darnley, A.G., 1972. "Airborne Gamma-Ray Survey Techniques," in Bowie, S.H.U., M. Davis, and D. Ostle, (eds.), Uranium Prospecting Handbook, institute of Mining and Metallurgy, London, p. 174-211.

3. Davis, F.J., and P.W. Reinhardt, 1957. "Instrumentation in Aircraft for Radiation Measurements," Nuclear Science and Engineering, vol.. 2, no.6, p. 713-727. 
4. Davis, F.J., 1962. "Radiation Measurements Over Simulated Plane Sources," Health Physics, vol. 8, p. 233-243.

5. Deal, I.J., et al., 1972. "Locating the Lost Athena Missile in Mexico by the Aerial Radiological Measuring System (ARMS), "Health Physics, vol. 23, p. 95-98.

6. DOE (U.S. Department of Energy), 1979a. Aerial Radiometric and Magnetic Survey, Death Valley National Topographic Map, California and Nevada, U.S. Department of Energy Open File Report GJBX-164(79), vol. 2, 386 p.

7. DOE (U.S. Department of Energy), 1979b. Aerial Radiometric and Magnetic Survey, Goldfield National Topographic Map, California and Nevada, U.S. Department of Energy Open File Report GJBX-66, vol. 2, 73 p.

8. DOE (U.S. Department of Energy), 1979c. Airborne Gamma-Ray Spectrometer and Magnetometer Survey, Kingman and Las Vegas Quadrangles, California and Nevada, U.S: Department of Energy Open Eile Report GJBX-59(80), vol. 2, $192 \mathrm{p}$.

9. DOE (U.S. Department of Energy), 1980. Aerial Radiometric and Magnetic Survey, Caliente National Topographic Map, Nevada and Utah, U.S. Department of Energy Open File Report-52(80), vol. 2, 198 p.

10. Duval, J.S., 1987. "Aerial Radiometric Color Contour Maps and Composite Color Map of Regional Surface Concentrations of Uranium, Potassium, and Thorium in Ohio," U.S. Geological Survey Geophysical Investigations Map GP-966.

11. Duval, J.S., 1988a. "Aerial Gamma-Ray Contour Maps of Regional Surface Concentrations of Potassium, Uranium, and Thorium in Nevada," U.S. Geological Survey Geophysical Investigations Map GP-982, 3 sheets, scale $1: 750,000$.

12. Duval, J.S., 1988b. "Aerial Gamma-Ray Contour Maps of Regional Surface Concentrations of Uranium, Potassium, and Thorium in New Mexico, "U.S. Geological Survey Geophysical Investigations Map GP-979, 3 sheets, scale $1: 750,000$.

13. Duval, J.S., 1989. "Aerial Gamma-Ray Color Contour Maps of Regional Surface Concentrations of potassium, Uranium, Thorium, and Composite-Color Maps of Uranium, Potassium, Thorium, and Their Ratios in New Mexico," U.S. Geological Survey Geophysical Investigations Map GP-980, 4 sheets, scale $1: 1,000,000$.

14. Duvel, J.S., and J.A. litkin, 1988. Interpretation of Aerial Gamma-Ray Data for Nevada, U.S. Geological Survey Open File Report 88-288, 12 p., 9 sheets, scale $1: 1,000,000$.

15. Geodata International, Inc., 1977. Lake Mead Dynamic Test Range for Calibration of Airborne Gamma Radiation Measuring Systems, U.S. Department of Energy Open File Report GJBX-46 (77), 83 p. 
16. Gnojek, Ivan, and A. Prichystal, 1985. "A New Zinc Mineralization Detected by Airborne Gamma-Ray Soectrometry in Northern Moravia (Czechoslovakia)," Geoexploration, vol. 23, no. 4, p. 491-502.

17. Grasty, R.I., and A.G. Darnley, 1971. The Calibration of Gamma-Ray Spectrometers for Ground and Airborne Use, Geological Survey of Canada Report 71-17, $27 \mathrm{p}$.

18. Guillou, R.B., 1964. "The Aerial Radiological Measuring Surveys (ARMS) Program," in Adams, J.A.S., and W.M. Lowder, eds., The Natural Radiation Environments, Chicago University Press, p. 705-721.

19. Killeen, P.G., 1979. "Gamma-Ray Spectrometric Methods in Uranium Exploration - Application and Interpretation," in Hood, P.J. (ed.), Geophysics and Geochemistry in the Search for Metallic Ores, Geological Survey of Canada Economic Geology Report 31, p. 163-229.

20. Lovborg, I., M. Lovberg, and E. Lovberg, 1987. "Counting Statistics in Radioelement Assaying with a Portable spectrometer," Geophysics, vol. 52 , no. 4, p. 555-563.

21. Pitkin, J.A., 1968. Airborne Measurement of Terrestrial Radioactivity as an Aid to Geologic Mapping, U.S. Geological Survey Professional Paper $516-\mathrm{F}, 29 \mathrm{p}$.

22. Pitkin, J.A., and J.S. Duval, in press. "Aerial Gamma-Ray Contour Maps of Regional Surface Concentrations of Uranium, Potassium, and Thorium] in Arizona," U.S. Geological Survey Geophysical Investigations Map GP-nnnn, 3 sheets, scale 1:1,000,000.

23. Pitkin, J.A., and A.C. Huffman, Jr., 1986. Geophysical and Geological Investigations of Aerial Radiometric Anomalies in the Tabuk Formation, Kingdom of Saudi Arabia, U.S. Geological Survey, Saudi Arabian Mission Open Fi.le Report USGS-OF-05-10, 20 p., 3 plates, scale 1:250,000.

24. Pitkin, J.A., 1989. Geophysical and Geological Investigations of Aerial Radiometric Anomalies in the Phanerozoic Cover Rocks of Southern Saudi Arabia, U.S. Geological Survey, Saudi Arabian Mission Open File Report USGS-OF-07-7, 17 p. 8 plates, scale 1:250,000.

25. Yeates, A.N., B.W. Wyatt, and D.H. Tucker, 1.982. "Application of Gamma-Ray Spectrometry to Prospecting for Tin and Tungsten Granites, Particularly within the Lachlan Fold Belt, New South Wales, "Economic Geology, vol. 77, p. 1725-1738.

26. Ward, D.L., 1978. Construction of Calibration Pads Facility, Walker. Field, Grand Junction, Colorado, U.S. Department of Energy Open File Report GJBX-37(78), $57 \mathrm{p}$. 


\subsection{BOREHOLE GEOPHYSICS AND PETROPHYSICAL MEASUREMENTS}

\section{OBJECTIVES}

The objectives for borehole geophysical surveys, as stated in section 8.3.1.4.2.1.3 of the Site Characterization Plan (SCE), are (1) to aid in the definition and refinement of the geometry and character of lithostratigraphic units and contacts between units, and (2) to determine the distribution of rock characteristics within lithostratigraphic units. Geophysical logs may be used as index tools for correlation betwenn drillholes without reprocessing of $\mathrm{log}$ responses, or different $\mathrm{log}$ responses may be combined in a computed log that represents some directly applicable site parameter such as volumetric moisture content.

\section{DATA COVERAGE AND QUALITY}

More than 500 geophysical logs have been acquired since 1978 by the Yucca Mountain Project, from 40 holes in Yucca Mountain and vicinity (Figure 2.7-1). Table 2.7-1 lists the types of logs that are available for each existing borehole. Most of these were acquired by the contracted logging service operating on the NTS (Birdwell or its successor company, DresserAtlas). Logs have been presented for boreholes UE25a\#1 (Spengler et al., 1979), USW G-1 (Muller and Kibler, 1983), USW G-4 (Spengler et al., 1984), UE-25p\#1 (Muller and Kibler, 1984) and 15 boreholes in the Wr series (Muller and Kibler, 1984). In addition, magnetometer logs have been acquired by Lawrence Livermore National Laboratory using methods described by Douglas and Millett (1978). Magnetic susceptibility and induced polarization logs have been acquired by the USGS in boreholes UE25a\#1 (Hagstrum et al., 1980a), UE25a\#5 (Hagstr... et al., 1980b), and UE25a\#4, a\#5, a\#6, and a\#7 (Daniels and Scott, 1981). Eorehole gravity measurements have been acquired by the USGS in boreholes USW H-1 (Robbins et al., 1982), UE25P\#1 and UE25C\#1 (Healey et al., 1984), and USW G-4 (Healey et al., 1986). The compilation and presentation of logs from all 40 boreholes listed in Table 2.7-1 is the subject of a report which is in progress.

Acquisition and interpretation of geophysical logs from drillholes in the Yucca Mountain site area is complicated by several factors:

1. Drillholes penetrate both saturated and unsaturated rocks. Some logs require fluid in the wellbore, and cannot be run effectively in the unsaturated zone. Others operate with reduced effectiveness, or have never been calibrated for unsaturated conditions in tuffaceous rocks. For example, compensated neutron logging tools were generally designed io operate in fluid-filled holes, where stray neutrons are readily captured. As a result, the conventional compensaied neutron tool has been used almost exclusively in the saturated zone at the site.

2. Drillholes are often quite rugose (i.e., borehole geometry varies considerably from a cylindrical opening at the nominal bit diameter) in welded units such as the Topopah Spring Member. Drilling dry, or 
with foam circulation in the unsaturated zone, may produce more severe rugosity because of the lack of supporting wellbore fluid. Also, for certain types of logging tools, the effects of rugosity on tool response may be accentuated without wellbore fluid. For example, the compensated density log is closely tied to formation bulk density, but contains low-density "spikes" caused primarily by rugosity. Severe rugosity is an environmental condition that adversely affects the response of most logging tools.

3. Drilling progresses in several stages to accommodate casing and measurement programs. Thus, the logs are acquired in stages, above or below the static water level, and often in holes of differing diameter. This requires added effort to select and splice logs from the various logging runs, and may introduce uncertainty with respect to tool response under varying logging conditions. This factor is represented in the various reports on the edited logs (e.g., Muller and Kibler, 1983, 1984a, and 1984b; Spengler et al., 1984; Hagstrum et al., 1980a).

Petrophysical measurements of core properties, on samples retrieved from logged drillholes, are very important to the logging program. Measurements of density, porosity, velocity, electrical properties, magnetic properties, and moisture saturation are generally needed to calibrate log measurements. Such data are available from core or cuttings samples, as applicable, from the nine boreholes listed in Table 2.7-2. In addition to the physical property data, mineralogical data on the tuffs acquired by X-ray diffraction has been summarized by Bish and Chipera (1989) for 17 boreholes. The mineralogy is expected to be quite valuable in relating log response to rock alteration.

The USGS Nuclear Hydrology Project has maintained a program of periodic relogging of shallow borings at Yucca Mountain since 1984, using neutron moisture meter tools. There currently are 74 such boreholes in the program, distributed among hydrologic settings that sample the variation of surficial materials and topography at the site. The depth of these borings is generally about $10 \mathrm{~m}$, although many are shallower and a few are deeper. Different types of neutron tools have been used, and are run without centralization. The holes are logged once per month, and also after or during major precipitation, runoff, or snownelt events. A program of crosshole gamma logging has also been carried out on a preliminary basis, in addition to the neutron logging. Crosshole logging is done in cased, parallel borings spaced about 2 m apart.

\section{SUMMARY OF RESULTS}

The first objective stated above consists of the task of correlation between drillholes using log character. Logs have been routinely used to confirm the location of bed boundaries based on changes in log response due to physical property changes. The compensated density log has been particularly useful, because density varies in a generally systematic way between welded and nonwelded units, and because ine $\log$ is available for all drillholes in both the saturated and unsaturated zones. The magnetic 


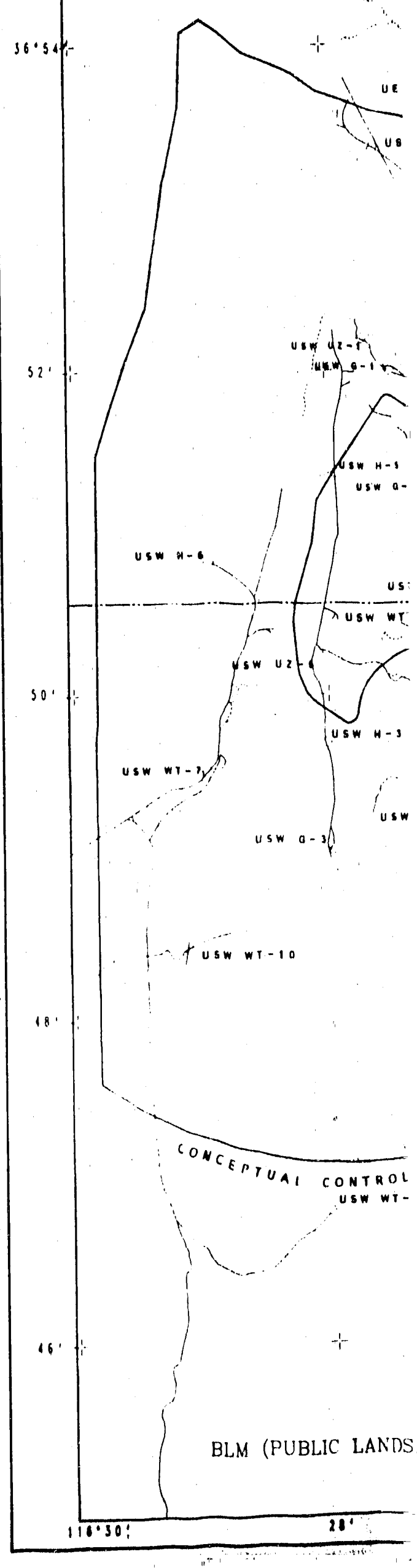




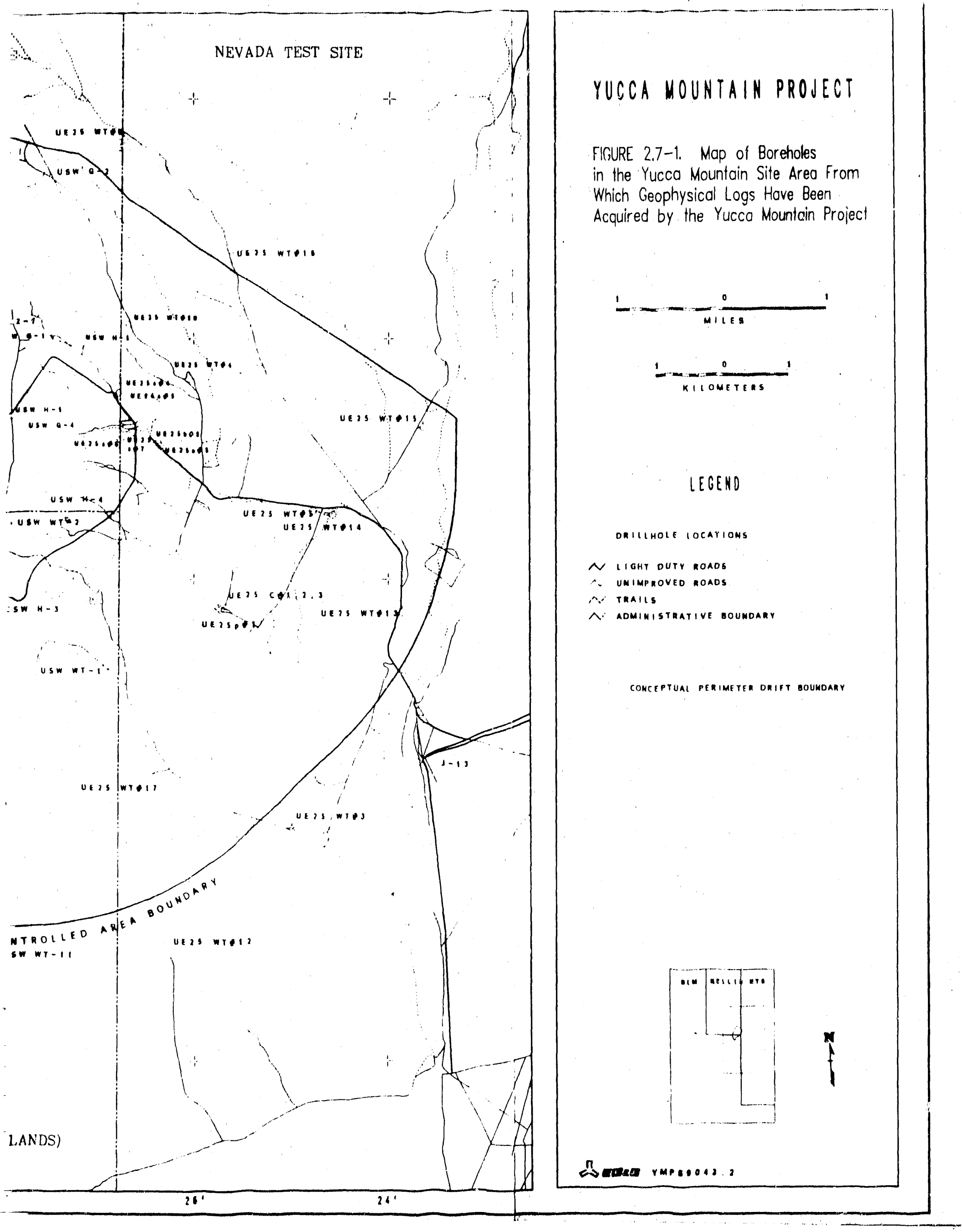




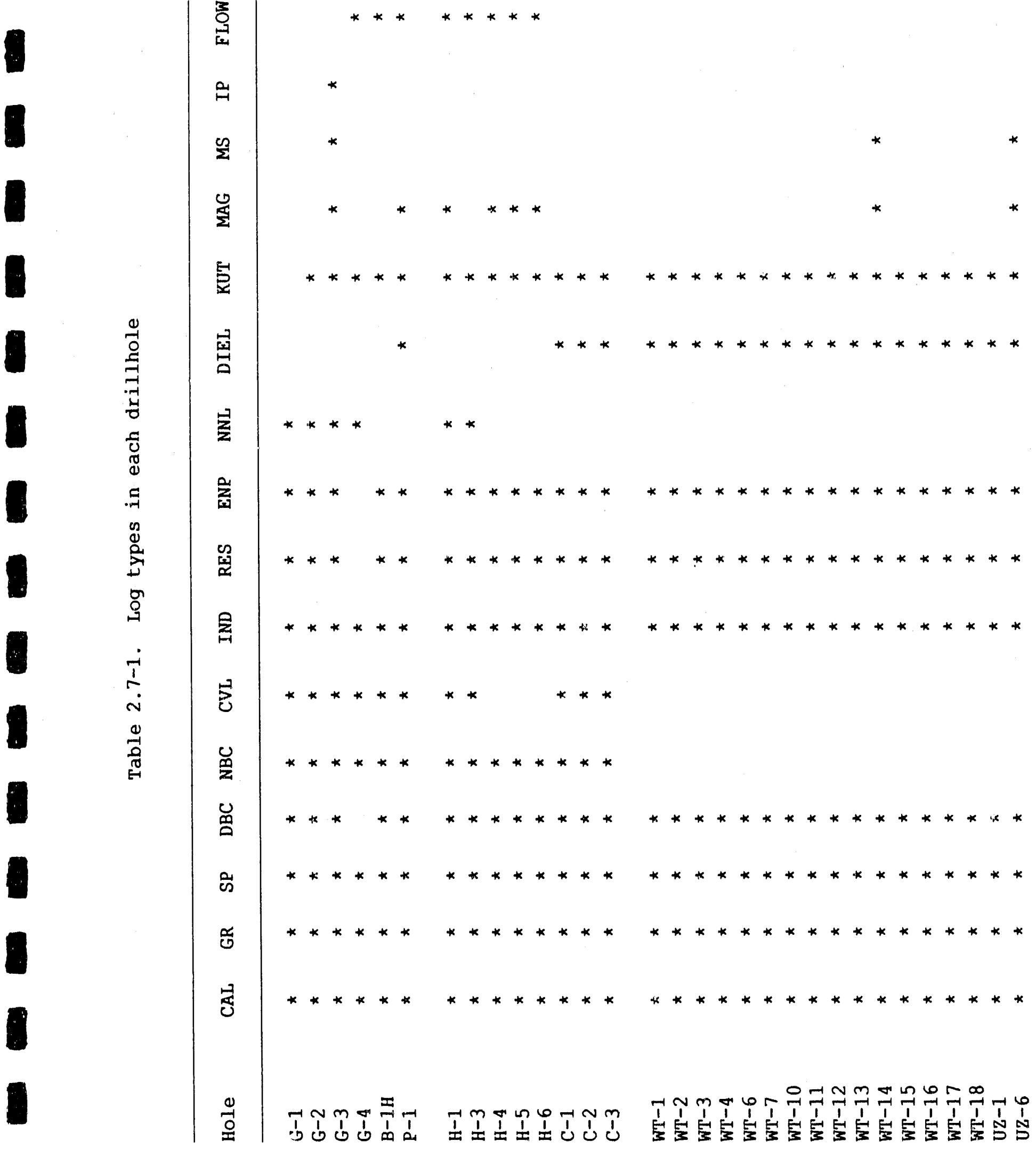



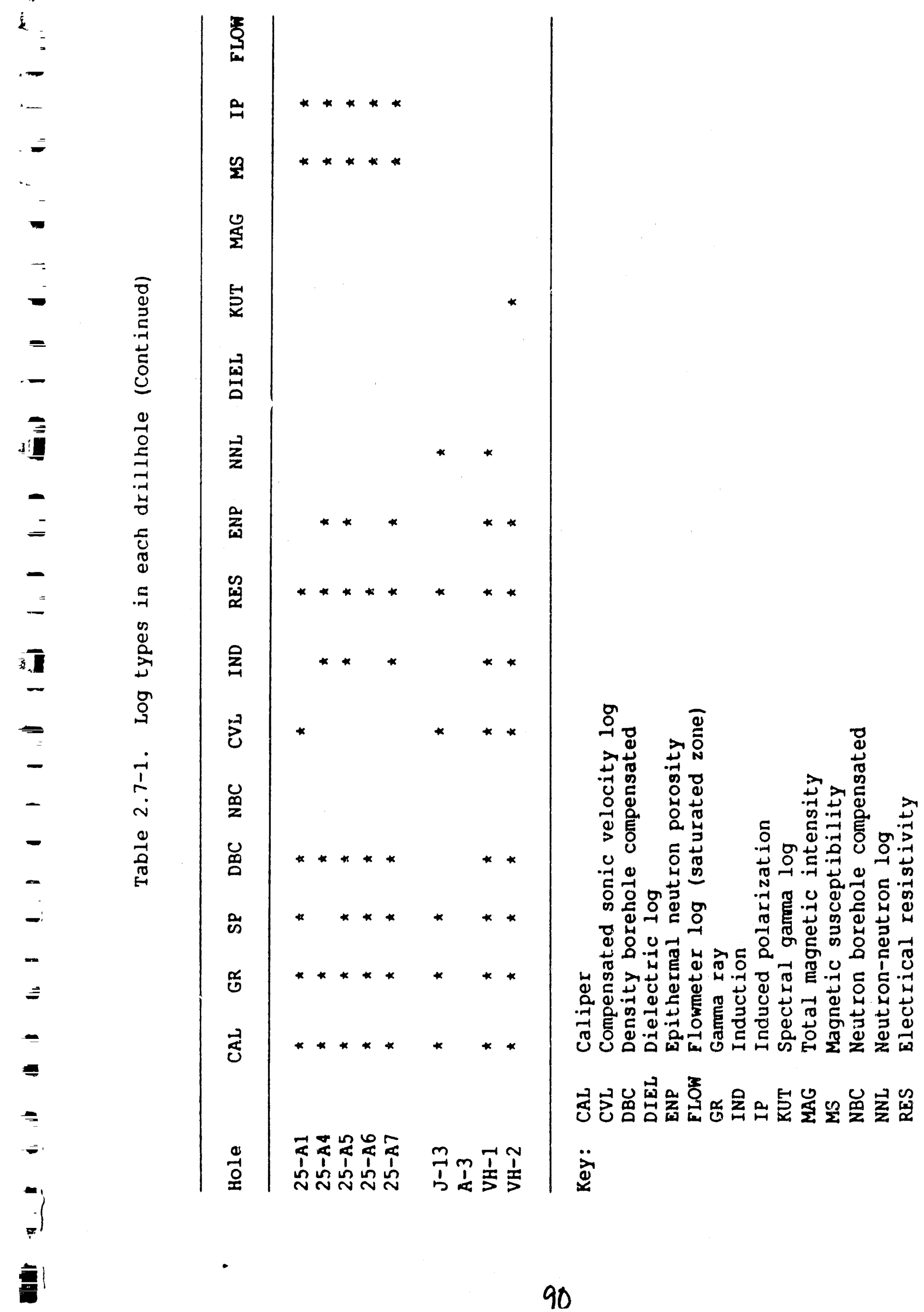


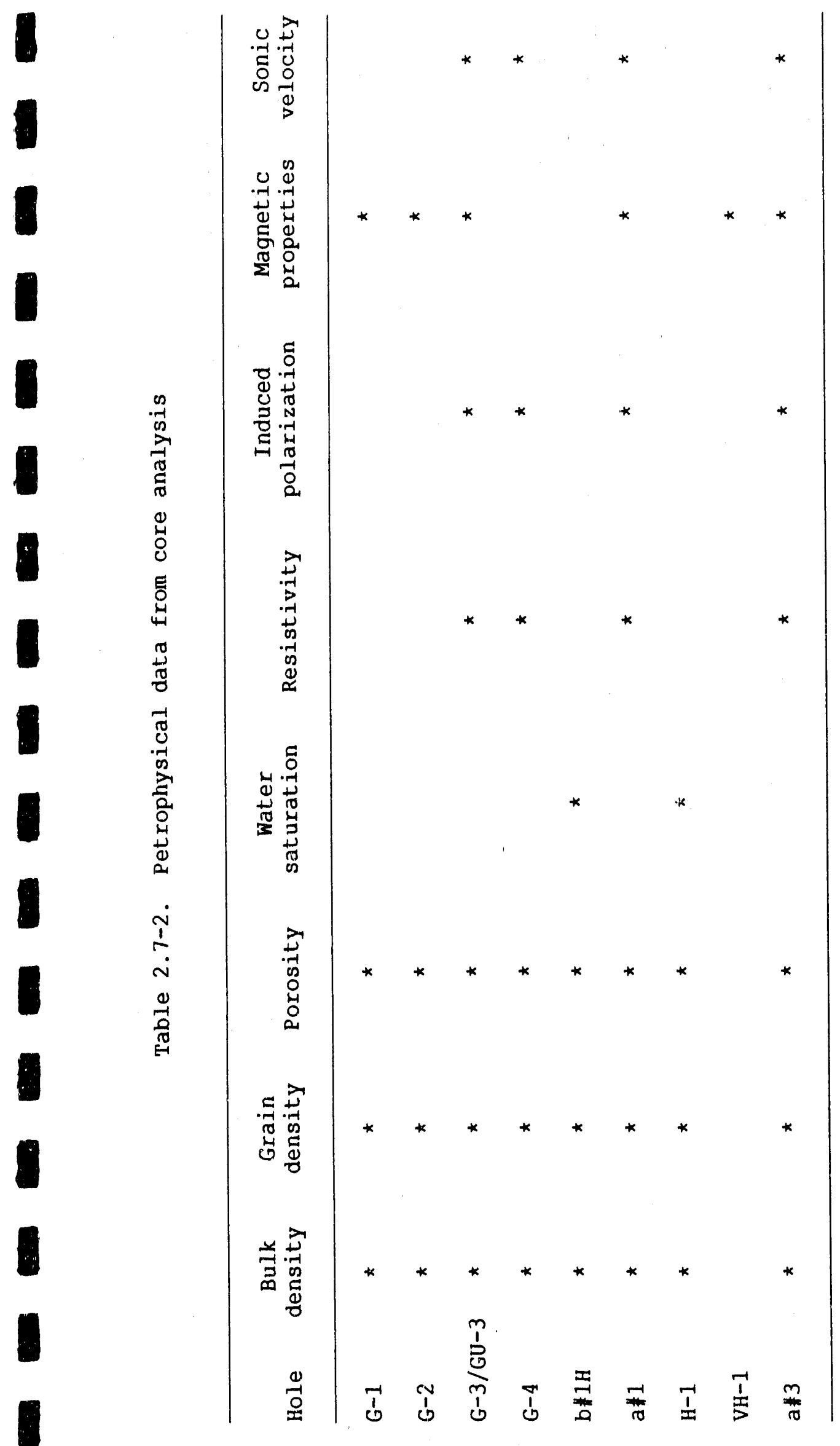


intensity and magnetic susceptibility logs provide unique lithostratigraphic information corresponding to strong remanent magnetization, and laterally contiguous compositional variability in the host rock and other ash flows. Large reversed polarization signatures in the Bullfrog Member of the Crater Flat Tuff and nomal polarization signatures in the Tram Member serve as marker horizons which can be traced from one drillhole to the next. Magnetic susceptibility logs are sersitive to the amount of magnetite and the size of magnetite crystals (Hagstrum et al., 1980b), and apparently reveal distinct eruptive events within thick ash flow sheets. The magnetic logs have been run on an experimental basis at Yucca Mountain, so few logs are presently available.

The gamma-ray log, which serves for lithologic correlation in sedimentary basins, is not as effective in the tuffs. It shows that the Topopah Spring Member of the Paintbrush Tuff is characterized by a relatively large and unvarying gamma-ray signature, and that the Prow Pass Member of the Crater Flat Tuff can be correlated between drillholes by a distinctive, blocky signature near the top of the unit.

The degree of welding, which can be described from observation of core, produces characteristic responses in the density and resistivity logs. The density $\log$ almost always indicates low density in bedded tuffs and in nonto partially-welded ash flow tuffs. Density increases as welding becomes moderate or dense. Superposed on the response to welding is an increase of density with increasing depth.

Resistivity of the Topopah Spring Member is high, usually greater than 200 ohm-meters, not only because the unit is unsaturated, but also because it is densely welded with consequent restriction in pore connectivity. By contrast, both the density and resistivity of the underlying Calico Hills unit are significantly lower. The relative differences between welded and nonwelded units are evident whether measurements are made abore or below the present water table, and are also consistent in drillholes distributed in the northern and southern portions of the site area. The nature of alteration may also produce characteristic log responses in the various units, particularly the Calico Hills tuffs, but present understanding of this phenomenon does not permit logs to be used to characterize alteration.

The second objective described above involves quantification cf physical properties that can be derived from logs, particularly density, velocity, resistivity, porosity, moisture content, and related characteristics such as pore connectivity, which may affect transport properties. Much use has already been made of geophysical logs in an unsystematic manner, as input for interpretation of surface or airborne geophysical surveys. A quantitative, systematic approach to $\log$ analysis is computationally intensive because corrections are needed for environmental effects, logs must be compared with core measurements, and logs must be compared together to ensure consistent interpretation. Work towards this second objective is currently in progress.

Extensive measurements of bulk and grain density, porosity, compressional velocity, resistivity, and induced polarization have been made on rock cores from eight drillholes at Yucca Mountain (Anderson, 1981a, 1981b, and 1984). Water permeability, magnetic susceptibility, and remanent magnetization have also been measured for samples from certain drillholes. 
Bulk density, resistivity, and sonic velocity are correlated to porosity, indicating the dependence of these properties on textural rather than compositional differences (Anderson, 1982). There are significant departures from simple dependence, probably associated with the effects of alteration processes such as devitrification and zeolitization. Resistivity measurements on resaturated core samples show that the ratural pore waters are quite fresh. Polarization measurements show that frequency effect cannot be relied upon as an indicator of clay or zeolite content. Low porosity tuff with few conduction paths and low content of polarizable material may exhibit polarization response comparable to high porosity tuff rich in clay minerals (Anderson, 1984). Specific capacity (or the frequency domain equivalent "metal factor") is a more reliable indicator of clay or zeolite content, but not without apparent conduction path effects.

\section{Fracture Detection/Characterization}

Fracture location and orientation data have been obtained from boreholes UE-25 C\#1 and UE-25 C\#2 using downhole video camera and borehole acoustic televiewer (BATV) logs. In UE-25 c\#3 only the BATV log was obtained. Boreholes drilled dry or with air foam at the site have generally provided sufficient optical clarity for use of borehole television both above and below the water table. Flow data obtained under pumping conditions (Erickson et al., 1985) and nonpumping conditions (Galloway and Erickson, 1985) indicate that fluid production occurs from fractures, but the majority of fractures observed do not contribute measurable flow. Flow is characterized by relatively large quantities of water entering the boreholes at a few discrete points or intervals.

Data on fracture locations and orientations have been obtained from downhole video camera and BATV logs in boreholes USW H-1, USW H-3, USW H-4, USW H-5, USW H-6, UE-25 b\#1, and UE-25 p\#1 (Craig and Robison, 1984; Erickson and Waddell, 1985; Lahond et al., 1984; Rush et al., 1983; Whitfield et al., 1985). Relations between fractures and intraborehole flow at these test wells are similar qualitatively to relations at boreholes UE-25 C\#1, c\#2, and c\#3. As efforts to relate fracture data to hydrologic information at $c \# 1$, $c \# 2$, and $c \# 3$ prove successful, these efforts will be extended to other test welis near Yucca Mountain Borehole Gravity.

Borehole gravity data have been acquired from five drillholes (UE25 p\#1, UE25 C\#1, USW G-3, USW G-4, and USW H-1) for the purpose of delineating large-scale density contrasts and refining density information used in gravity modeling (Healey et al., 1984, 1986; Robbins et al., 1982). Gravity stations have been acquired at $7.6 \mathrm{~m}$ stations over much of the length of these drillholes, and is of sufficient resolution and accuracy (in conjunction with free-air and terrain corrections) such that $10 \%$ or more lithophysal porosity in a layer as thin as $7.6 \mathrm{~m}$ should be detectable.

\section{Neutron Moisture Meter Logging}

As many as 74 shallow borings have been logged periodically over the past five years, principally using hand-held borehole neutron moisture meters. The purpose of this logging program is to monitor the frequency and extent of natural infiltration in different surface hydrogeologic settings at the site. The tools are read on station at 10 to $20 \mathrm{~cm}$ depth increments, and 
at monthly intervals or more frequently in response to precipitation events that are judged likely to produce measurable infiltration.

The borings were drilled dry, with 125-mm steel casing uncemented except for a grout seal at the ground surface. Although smaller diameter borings and aluminum casing are standard practice in moisture logging, steel casing was selected for compatibility with the available ODEX drilling system. This system is an effective method for dry drilling in variable alluvium with abundant boulders. Calibration tank studies discussed below show that useful sensitivity is retained with the method used. Recently, other drilling methods have been tried, or become available, including small diameter ODEX tools. These provide smaller borings and support the use of thinner wall casing. Steel casing remains a requirement for strength, but does not appear to degrade performance significantly. The moisture meter is run uncentralized, and consists of a $50 \mathrm{mCi} \mathrm{Am} / \mathrm{Be}$ source with a closely spaced detector of thermal neutrons. The moisture meter effectively provides a point measurement of the moderating and capture cross sections of the formation, which are predominantly controlled by moisture content in unsaturated volcanic tuff.

Calibration tank studies and independent moisture measurements in boreholes indicate that, as applied in the prograrn, the logging method can resolve changes in neutron counts on the order of $2 \%$, which translates roughly into resolution of about 28 on the volumetric amount of water present.

The following general observations apply to moisture transients, observed primarily in alluvium: (1) transients corresponding to precipitation or snowmelt events can be observed in many borings, (2) the donward progress of such transients can typically be monitored over tens to hundreds of days, and (3) the magnitude of such transients typically diminishes with depth. Indications of more rapid infiltration in response to precipitation events have been obtained from a small minority of the existing neutron holes. Although the number of observations is limited, instances of water collecting at the bottom of neutron holes are consistent with perching above the bedrock-alluvium contact. (This paragraph derives from verbal communication, A. Flint, 2-12-90.)

The maximum measured depth of penetration of moisture transients is typically 5 to $10 \mathrm{~m}$ for the existing borings, and no transients have been detected below $12 \mathrm{~m}$. It is important to observe that most of the existing neutron holes are collared in alluvium, and extend just beyond the bedrock-alluvium contact. The depth of neutron holes thus varies from less than $10 \mathrm{~m}$ to $15 \mathrm{~m}$ or more. Crosshole gamma-gamma surveys have been run periodically using a small number of closely spaced borings. The response of single-hole tools is apparently consistent with crosshole measurements, which are sensitive to a larger volume.

\section{Other Slim-Hole Moisture Logging}

Several of the shallow infiltration monitoring boreholes have been logged with a Mount Sopris single-conductor logging system to investigate through-casing logging methods suitable for the Uz hydrology program. Three tools were used: short- and long-spacing neutron tools, and a single- 
detector density tool. These were found to be inadequate for measuring water content and density wi.th useful accuracy. As expected, the single-detector density tool was sensitive to borewall irregularity behind the casing. Data from the short-spacing neutron tool compared favorably to that from the neutron moisture meter logging program, and exhibited similar borehole effects. The long-spacing neutron tool also exhibited both sensitivity to moisture content and borehole effects. (A dual-spacing neutron tool is available from this source and will be tried.)

\section{Related Infiltration Data from Borehole Geophysics}

Infiltration penetrating deeper than $12 \mathrm{~m}$ has been inferred for only one borehole, from geotemperature data. (Note: heat flow studies are not covered by this paper.) Sass et al. (1988) discussed repeat temperature logs from borehole UE25 a\#7, in the bottom of Drill hole Wash about $0.5 \mathrm{~km}$ east of the planned location of the Exploratory shaft Facility. This borehole was drilled in August 1979 with mud, some of which was lost to the formation. The hole was completed with a string of water-filled steel tubing for temperature logging. Repeated temperature logs (March, 1981; April, 1981; December, 1981; March, 1983; and March, 1984; see Sass et al., 1988) show the hole to have equilibrated conductively from the effects of drilling (a typical response for Yucca Mountain boreholes) until early 1983. The temperature profile acquired in March 1983, shortly after a major precipitation event, is disturbed down to about $120 \mathrm{~m}$ depth. The March 1984 profile shows the disturbance to have equilibrated, such that the profile resembles that acquired soon after driling. Fluid evidently entered the borehole, which is situated within the ephemeral channel in Drill Hole Wash. However, it is not known whether fluid entered the borehole through (1) the top of the surface casing as a result of overtopping by the runoff; (2) the alluvium at the bottom of the surface casing, above the bedrock contact; or (3) fracture pathways beneath the channel and intersecting the borehole at depth.

BIBLIOGRAPHY FOR SECTION 2.7

Anderson, L.A., 1981. Rock Property Analysis of Core Samples from the Calico Hills UE25 a\#3 Borehole, Nevada Test Site, Nevada, U.S. Geological Survey Open File Report 81-1337.

Anderson, I.A., 1981. Roak Property Analysis of Core Samples from the Yucca Mountain UE2 a\#1 Borehole, Nevada Test Site, Nevada, U.S. Geological Survey Open File Report 81-1338.

Anderson, I.A., 1982. Rock Property Analysis for Core Samples from Yucca Mountain Boreholes, Nevada Test Site, Nevada (abs), EOS Transactions of the Fall, 1982 meeting of the American Geophysical Union, San Francisco, California, p. 1111.

Anderson, L.A., 1984. Rock Property Measurements on Large-Volume Core Samples from Yucca Mountain USW GU-3/G-3 and USW G-4 Boreholes, Nevadis Test Site, Nevada, U.S. Geological Survey Open File Report 84-552, 39 pp. 
Bish, D.I., and S.J. Chipera, 1989. Revised Mineralogic Summary of Yucca Mountain, Nevada, Los Alamos National Laboratory Report LA-11497-MS.

Craig, R.W., and J.H. Robison, 1984. Geohydrology of Rocks penetrated by Test Well UE25 p\#1, Yucca Mountain Area, Nye County, Nevada, U.S. Geological Survey Open File Report 84-4248, 57 p.

Daniels, J.J., and J.H. Scott, 1980. Borehole Geophysical Measurement for Hole UE25a-3, Nevada Test Site, Nuclear Waste Isolation Program, U.S. Geological Survey Open File Report 80-126, 30 p.

Daniels, J.J., J.H. Scott, and J.T. Hagstrum, 1981. Interpretation of Geophysical Well-Log Measurements in Drillholes UE25 a-4, $-5,-6$, and -7 , Yucca Mountain, Nevada Test Site, U.S. Geological Survey Open File Report 81-615.

Douglas, A.C., and M.R. Millett, 1978. Total Intensity Magnetometer Logging as a Stratigraphic Tool in Tertiary Volcanic Rock, Lawrence Livermore National Laboratory Report UCRL-52617.

Erickson, J.R., D.I. Galloway, and K. Karasaki, 1985. Interpretation of Falling-Head Injection Test Data for Fractured Volcanic Tuffs, Yucca Mountain, Nevada Test Site, Geological Society of America, Fall 1985 meeting (Orlando, Florida).

Erickson, J.R., and R.K. Waddell, 1985. Identification and Characterization of Hydrologic Properties of Fractured Tuff Using Hydraulic and Tracer Tests --Test Well USW H-4, Yucca Mountain, Nye County, Nevada, U.S. Geological Survey Water Resources Investigations Report 85-4066, 55 p.

Galloway, D.I., and J.R. Erickson, 1985. Tracer Test for Evaluating Nonpumping Intraborehole Flow in Fractured Media, Transactions, American Nuclear Society, vol. 50, Nuclear Techniques for Hydrogeological studies, p. 182-192.

Hagstrum, J.T., J.J. Daniels, and J.H. Scott, 1980a. Interpretation of Geophysical Well-Iog Measurements in Drillhole UE25a-1, Nevada Test Site, Radioactive Waste Program, U.S, Geological Survey Open File Report 80-941, $32 \mathrm{p}$.

Hagstrum, J.T., J.J. Daniels, and J.H. Scott, 1930b. Analysis of the Magnetic Susceptibility Well Log in Drillhole UE25 a-5, Yucca Mountain, Nevada Test Site, U.S. Geological Survey Open File Report 80-1263, 32 pp.

Healey, D.I., F.G. Clutsom, and D.A. Glover, 1984. Borehole Gravity Meter Surveys in Drillholes USW G-3, UE25p\#1, and UE25c\#1, Yucca Mountain Area, Nevada, U.S. Geological Survey Open File Report 84-672, 16 p.

Healey, D.I., E.G. Clutsom, and D.A. Glover, 1986. Borehole Gravity Meter Survey in Drillholes USW G-4, Yucca Mountain Area, Nye County, Nevada, U.S. Geological Survey Open File Report 86-205, 18 p.

Lahund, R.G., D.H. Lobmeyer, and M.S. Whitfield, Jr., 1984. Geohydrology of Volcanic Tuff Penetrated by Test Well UE-25 b\#1, Yucca Mountain, Nye 
County, Nevada, U.S. Geological Survey Water Resources Investigation Report $84-4253,44 \mathrm{p}$.

Muller, D.C., and J.E. Kibler, 1983. Commercial Geophysical Logs from the USW G-1 Drillhole, Nevada Test Site, Nevada, U.S. Geological Survey Open File Report 83-321, $7 \mathrm{p}$.

Muller, D.C., and J.E. Kibler, 1984a. Preliminary Analysis of Geophysical Logs from Drillhole UE25 p\#1, Yucca Mountain, Nye County, Nevada, U.S. Geological Survey Open File Report 83-321, 7 p.

Muller, D.C., and J.E. Kibler, 1984b. Preliminary Analysis of Geophysical Logs from the WT Series of Drillholes, Yucca Mountain, Nve County, Nevada: U.S. Geological Survey Open File Report 86-46, 30 p.

Nimick, F.B., and B.M. Schwartz, 1987. Bulk, Thermal, and Mechanical Properties of the Topopah Spring Member of the Paintbrush Tuff, Yucca Mountain, Nevada, Sandia National Laboratories Report SAND85-0762, UC-70.

Robbins, S.I., J.W. Schmoker, and T.C. Hester, 1982. Principal Facts and Density Estimates for Borehole Gravity Stations in Exploratory Wells Ue 4ah, Ue 7j, Ue1h, Uela, Ue2co, and USW $\mathrm{H}-1$ at the Nevada Test Site, Nye County, Nevada, U.S. Geological Survey Open File Report 82-277, 33 p.

Rush, F.E., W. Thordarson, and I. Bruckheimer, 1983. Geohydrology of Test Well USW H-1, Yucca Mountain, Nye County, Nevada, U.S. Geological Survey Water Resources Investigation Report 83-4032, 38 p.

Sass, J.H., A.H. Lachenbruch, W.W. Dudley, Jr., S.S. Priest, and R.J. Munroe, 1988. Temperature, Thermal Conductivity, and Heat Flow Near Yucca Mountain, Nevada: Some Tectonic and Hydrologic Implications, U.S. Geological Survey Open File Report 87-649.

Spengler, R.W., D.C. Muller, and R.B. Livermore, 1979. Preliminary Report on the Geology and Geophysics of Drillhole UE25a-1, Yucca Mountain, Nevada Test Site, U.S. Geological Survey Open File Report 79-1244, 43 p.

Spengler, R.W., M.P. Chornack, D.C. Muller, and J.E. Kibler, 1984.

Stratigraphic and Structural Characteristics of Volcanic Rocks in Core Hole USW G-4, Yucca Mountain, Nye County, Nevada with a Section on Geophysical Logs, U.S. Geological Survey Open File Report 84-789, 77 p.

Whitfield, M.S., Jr., E.P. Eshom, W. Thordarson, and D.H. Schaeter, 1985. Geohydrology of Rocks Penetrated by Test Well USW H-4, Yucca Mountain, Nye County, Nevada, U.S. Geological Survey Water Resources Investigation Report 85-4030, 33 p. 


\subsection{TELESEISMIC TOMOGRAPHY SURVEYS}

\section{OBJECTIVES}

Teleseismic tomography has been used in the Yucca Mountain site area and region primarily for detection of extant magma chambers larger than about $4 \mathrm{~km}$ across, and to help map deep tectonic structures that might be important to repository performance. These studies are directly pertinent to NRC staff concerns expressed to the DOE (e.g., Comments \#49 and \#51 of the "Point Papers" response to the Consultation Draft Site Characterization Plan). Teleseismic tomography is routinely successful for delineating silicic magma chambers in the crust and partial melts in the upper mantle. Iyer (1987) reviews teleseismic tomography results and other seismic studies for a large range of volcanic systems.

Structures affecting the repository may be of almost any size. Regional teleseismic tomography delineates upper-mantle structures that may be related to plate motions and large-scale magmatism, such as the Miocene alderas of the Timber Mountain-Silent Canyon complex. Regions of upper-mantle partial melt that could supply basalt lava to eruptions near the repository can be delineated at this scale as well. At finer scales, major faults offsetting the Paleozoic basement beneath the tuff uection have discernible teleseismic signatures because of the strong velocity contrast. Using this signature, buried faults can be located. Crustal silicic magma chambers larger than about $4 \mathrm{~km}$ across also can be imaged using fine-scale data. Magma chambers this size and larger have been imaged routinely below active silicic volcanic centers in the western U.S. The absence of low-velocity features this size at Yucca Mountain would be a positive result indicating diminished likelihood of silicic eruptions in the site area.

\section{DATA COVERAGE AND QUALITY}

Data are available for the Yucca Mountain area at three scales (Figure 2.8-1). First, data from the regional Southern Great Basin (SGB) network provide a large array aperture, and therefore great maximum depth of imaging, but the stations are far apart, limiting the resolving power of the network. The data of Monfort and Evans (1982), combired with a completed but unpublished data set acquired by J.R. Evans, provide 26-km lateral resolution to a depth of about $345 \mathrm{~km}$ in all of southern Nevada and neighboring parts of southeast California. The major findings of Monfort and Evans (1982) are not shanged by these new data, but resolution characteristics are improved.

Second, later addition to the SGB network of six stations around Yucca Mountain itself (Figure 2.8-1c, five solid symbols in site area and one just west), combined with temporary deployment of 20 portable seismographs (Figure 2.8-1c, open symbols), created a circular array of seismographs with mean station spacing of about $4 \mathrm{~km}$ within a $15-\mathrm{km}$ radius around the repository. This array can resolve objects as small as $4 \mathrm{~km}$ across and probe to Moho depth or slightly below. This temporary deployment was specifically designed to provide information on any small $(>4 \mathrm{~km})$ crustal silicic magma chambers in the site area. 


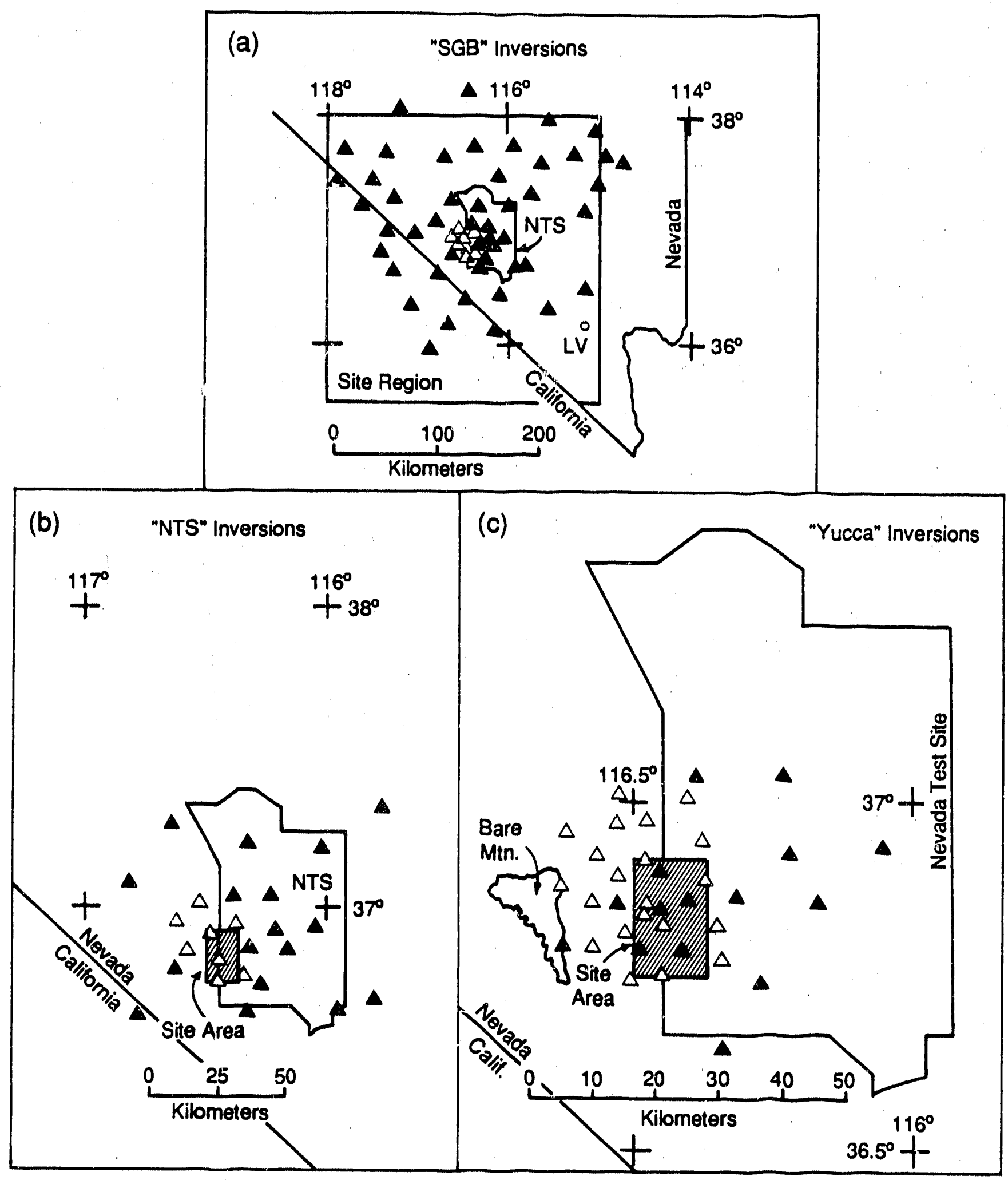

Figure 2.8-1. Maps of seismograph stations used in teleseismic tomography studies. Permanent stations of the SGB network are shown as solid symbois; portable stations installed around Yucca Mountain in 1982 are shown by open symbols. Site area hachured. (a) Map showing stations used in regional ("SGB") inversions of data from the whole SGB network. "LV" is Las Vegas. (b) Mid-scale map showing stations used in mid-scale ("NTS") inversions. (c) Map showing stations used in fine-scale (Yucca") inversions. 
Last, the SGB network is denser in the NTS area. Hence, intermediatescale images with up to $12-\mathrm{km}$ resolution and imageable depth of $120 \mathrm{~km}$ are possible in this region. However, this resolution decreases toward the edges of the array more rapidly than is usual for teleseismic images. Images at both of these finer scales have now been produced. The new images and the revised images of regional-scale features are discussed in an interpretive report and a data report, both now in preparation by J.R. Evans and M. Smith.

The resolution values given above apply to the shallower parts of the images in the well-sampled parts of the region. Resolution degrades slowly with increasing depth and rapidly beyond the edges of the seismograph array. jertical resolution is not as good as horizontal; in particular, vertical. resolution of the finest-scale images is about $12 \mathrm{~km}$ near the surface. A special class of vertically limited but horizontally extensive objects may go completely unobserved or be resolved only at their edges. Additionally, the number of readings and the distribution on the globe of teleseismic sources used in the experiment can reduce the effective resolution or cause artifacts that must be evaluated expertly. Nevertheless, magma chambers comparable to those under Long Valley and the Mono Craters, California (Dawson et al., 1989; Achauer et al., 1986), or San Francisco Mountain, Arizona (Stauber, 1982), and within about $10 \mathrm{~km}$ of the repository would be resolved with these data.

A related data set has been produced from evaluation of refracted arrivals, from underground nuclear explosions (UNES). These data are reduced. in terms of travel time residuals for stations located throughout yucca Mountain and vicinity (Walch and Phillips, 1989; Walch, 1988; Hoffman and Mooney, 1983). Because the UNE first arrivals are refracted along a crustal horizon, the residuals apply only to the velocity structure of the upper and middle crust.

\section{SUMMARY OF RESULTS}

Monfort and Evans (1982) summarize results for data collected from the regional SGB network in 1979 and 1980. Combined with 1982 data (currently unpublished), the major features seen are (1.) a high-velocity upper-mantle anomaly beneath the northern part of the NTS and the Silent Canyon caldera; (2) a low-velocity upper-mantle region beneath the southern part of the NTS and eastward; (3) crustal low-velocity anomalies beneath the Silent Canyon caldera, the southern part of the NTS, Crater Flat, and several other stations; (4) high crustal velocity beneath stations on and near Paleozoic outcrops; and (5) a high-velocity upper-mantle feature beneath the Funeral Mountains-Death Valley region.

Though the high-velocity upper-mantle anomaly beneath the Silent Canyon caldera is better resolved by current data than by any previous study, it also has been observed by Spence (1974), Minster et al. (1981), and Taylor (1983), using teleseismic recordings of NTS tests. The anomaly may be residuum of a magma chamber associated with the Miocene volcanism that generated thick layers of tuff in this ragion. If so, this result implies that this system is inactive at its roots. The low-velocity upper-mantle anomaly beneath the southern part of the NTS is of unknown origin, but may be 
a region of partial melt associated with recent basaltic volcanism south of the repository site. However, other interpretations are equally plausible. This matter merits further investigation.

Preliminary data from the dense 1982 temporary array were used by Evans and Oliver (1987) to infer a strong correspondence between the portion of the teleseismic residuals caused by shallow $(<5 \mathrm{~km})$ structure and isostatic residual gravity. This correspondence implies that the thickness of tuff overlying Paleozoic basement rocks is mirrored in these data; a combined interpretation of gravity and teleseismic data may clarify the geometry of this interface. Both types of data indicate that an important structural boundary is present beneath or very rear the repositury block, where the eastern edge of the basin beneath Crater klat apparently runs east of teleseismic stations in Solitario Canyon. This boundary should be located more precisely; a high-resolution active-source analogue of teleseismic tomography (Achauer et al., 1288; Evans and Zucca, 1988) can accomplish this goal and should be considered.

The significance of Crater Flat is an issue of some importance to structural models of the Yucca Mountain region. It may be one or more Miocene calderas, or simply a graben, possibly related to Miocene volcanism north of Crater Flat in the Timber Mountain-Oasis Valley caldera complex. The new teleseismic data suggest the former, in that an apparent low-velocity anomaly is present beneath Crater Flat in the middle and lower crust. (The velocity model was corrected for reasonably well-known, near-surface velocity structure such as the volcanic section in Crater $\bar{F}$ lat; details of this correction will be provided in the forthcoming report.) This columnar low may extend into the upper crust as well, but current data do not resolve the junction region between it and the shallow basin known to exist beneath Crater Flat. These two features may be either connected or separated. The low-velocity anonaly may be caused by Miocene piston-like collapse of a caldera over a now-solidified magna source near the Moho, or it may represent a modern thermal disturbance, possibly related to Quaternary basaltic volcanism.

\section{BIBLIOGRAPHY FOR SECTION 2.8}

Achauer, U., J.R. Evans, and D.A. Stauber, 1988. "High-Resolution Seismic Tomography of Compressional Wave Velocity Structure at Newberry Volcano, Oregon Cascade kange," Journal of Geophysical Research, vol. 93, p. 10,135-10,147.

Achauer, U., I. Greene, J.R. Evans, and H.M. Iyer, 1986. "Nature of the Magma Chamber Underlying the Mono Craters Area, Eastern California, As Determined from Teleseismic Travel Time Residuals," Journal of Geophysical Research, vol. 91, p. 13,873-13,891.

Dawson, P.B., H.M. Iyer, and J.R. Evans, 1989. "Teleseismic Tomography of the Compressional Wave Velocity Structure Beneath the Iong Valley Region, California," Journal of Geophysical Research (in JGR review). 
Evans, J.R., and H.W. Oliver, 1987. "Comparison of Timber Mountain Caldera Complex, Nevada, with Yellowstone: Speculations on Mechanism" (extended abstract), Abstract Volume, Hawaii Symposium on How Volcanoes Work, 67, Hawaii Volcano Observatory, Hilo, Hawaii.

Evans, J.R., and J.J. Zucca, 1988. "Active High-Resolution Seismic Tomography of Compressional Wave Velocity and Attenuation Structure at Medicine Lake Volcano, Northern California Cascade Range," Journal of Geophysical Research, vol. 93, p. 15,n16-15,036.

Hoffman, L.R., and W.D. Mooney, 1983. A Seismic Study of Yucca Mountain and Vicinity, Southern Nevada: Data Report and Preliuinary Results, U.S. Geological Survey Open File Report 83-588, 50 p., 1 plate.

Iyer, H.M., 1988. "Seismolngical Detection and Delineation of Magma Chambers Beneath Intraplate Volcanic Centers in Western U.S.A.," in Modeling of Volcanic Processes, edited by C.Y. King and R. Scarpa, 1-56, Friedr. Vieweg und Sohn, Wiesbaden.

Minster, J.B., J.M. Savino, W.I. Rodi, J.F. Masso, and T.H. Jordan, 1981. "Three-Dimensional Velocity Structure of the Crust and Upper Mantle Beneath the Nevada Test Site" (abstract), EOS, Trans. AGU, 62, 972.

Monfort, M.E., and J.R. Evans, 1982. Three-Dimensional Modeling of the Nevada Test Site and Vicinity from Teleseismic P-Wave Residuals, U.S. Geological Survey Open File Report 82-409, 66 p.

Spence, W., 1974. "P-Wave Residual Differences and Inferences on an Upper Mantie Source for the Silent Canyon Volcanic Centre, Southern Great Basin," Geophysical J. R. Astron. Soc., 38, 505-524.

Stauber, D.A., 1982. "Two-Dimensional Compressional Wave Velocity Structure Under San Francisco Volcanic Field, Arizona, from Teleseisinic P Residual Measurements," Journal Geophysical Research, vol. 87, p. 5451-5459.

Taylor, S.R., 1983. "Three-Dimensional Crust and Upper Mantle Structure at the Nevada Test Site," Journal of Geophysical Research, vol. 88, p. 2220-2232.

Walch, M.C., and J.S. Phillips, 1989. TwC-Dimensional Velocity Models for Paths from Pahute Mesa and Yucca. Flat to Yucca Mountain, SAND88-3033, Sandia National Laboratories, Albuquerque, New Mexico.

Walch, M.C., 1988. "Modeling of Anomalous Ground Motion Observed at Jackass Flats, Nevada Test Site" abstract, Seism. Res. Lett., vol. 59, no. 31. 


\subsection{PLANNED GEOPHYSICAL ACTIVITIES}

This chapter presents planned geophysical activities in a manner that is organized around specific applications and needed information. This complements the Site Characterization Plan (SCP), which does not present a distinct geophysics program per se. In the SCP, plans for geophysical activities are typically intermingled with non-geophysical studies, and similar geophysical activities are discussed in different sections. This chapter also associates plans for future geophysical activities with results obtained from past activities, to the extent that these results have been used in the planning process.

A summary of planned activities is presented in Table 3.1-1. This summary includes information from similar tables in the SCP (Table 8.3.1.4-4); with some additional detail provided.

A report by Jones et al. (1987) and a paper by Wynn and Roseboom (1987) on geophysical techniques for site characterization present useful summaries of the general attributes of various geophysical techniques; this information will not be repeated here. Rather, this section elaborates upon specific applications of geophysics at the Yucca Mountain site. The report by Jones et al. identified a number of methods that have not been previously used at the site. Accordingly, present plans include testing of various methods prior to full-scale implementation for site characterization.

This chapter contains some new insights from the editors, and from the Project investigators responsible for geophysical activities. For the most part, this chapter is consistent with the SCP and recently drafted study Plans. Some of the relevant content of the SCP from Investigations 8.3.1.17.4 and 8.3.1.4.2 is reiterated for clarity. Activity descriptions in the SCP and Study Plans, and information in the Site Characterization Technical Planning Basis (DOE, 1989), are controlled by the DOE. This report, particularly section 3, represents a working position on the application of ceophysics, and is not part of a controlled planning basis. Discrepancies between information contained in this report and in the documents listed above should be regarded in favor of the controlled sources. Whereas this report identifies some new exploration concepts and elaborates on some activity descriptions in the SCP, changes to the scope of work described by the SCP and Study Plans, or to the information contained in the technical baseline (DOE, 1989), need to be reviewed and approved in accordar ze with change control procedures before becoming part of the controlled planning basis for site characterization. Also, it is important to recognize that a systematic effort to set priorities for surface-based testing, in a manner that will provide data for evaluating siting criteria of 10 CFR 60.122, is underway at the time of publication of this report.

Geophysical participation in site characterization is discussed in the following subsections for hydrologic, geologic, tectonic, and engineering appiications (Sections 3.1.1 to 3.1.6). A description of activities related to the geophysics integration activity (SCP Section 8.3.1.4.1.2) including recommendations of a feasibility testing program and a preliminary prioritization of geophysical activities is given in section 3.2. The section on feasibility studies (Section 3.3) describes a means fo: timely acquisition of certain limited but important informarion that is needed to 
further develop the geophysics program. The important question of integrating older geophysical data with newer data sets is considered in Section 3.4 . 


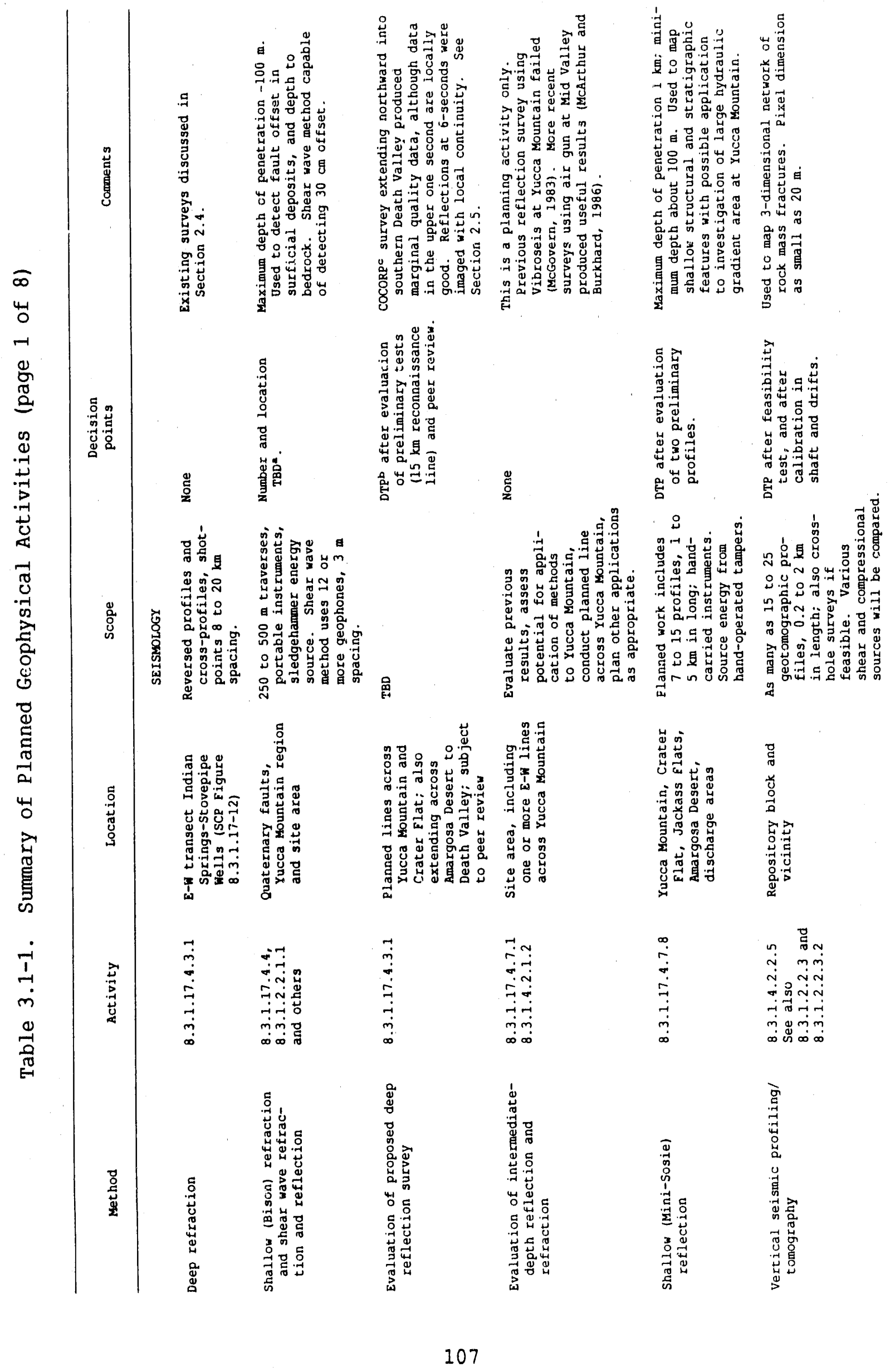


1)

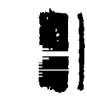

.

$=$

I

ब

]

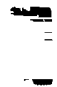

咅

青

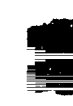

琣

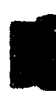

7

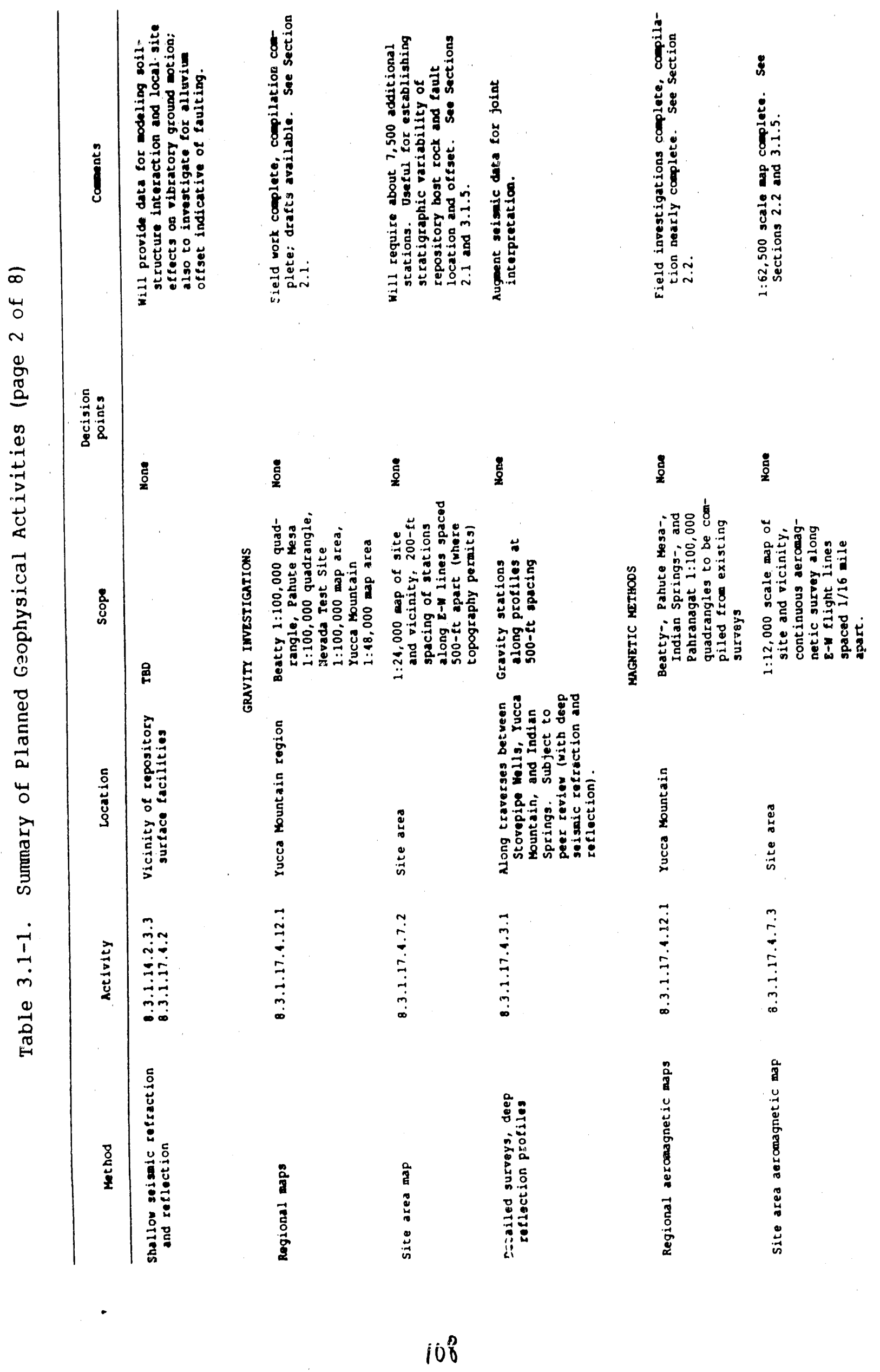




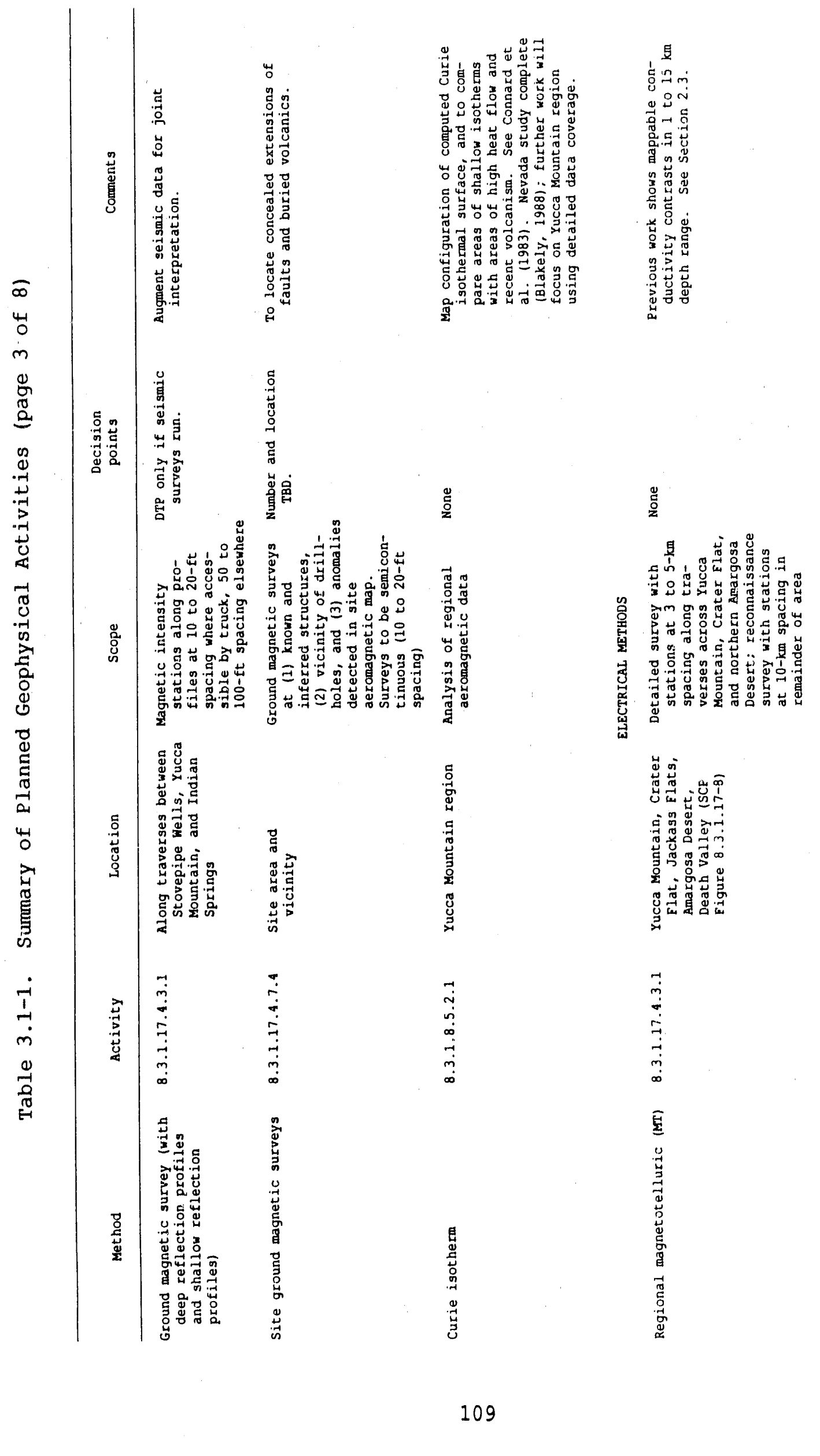




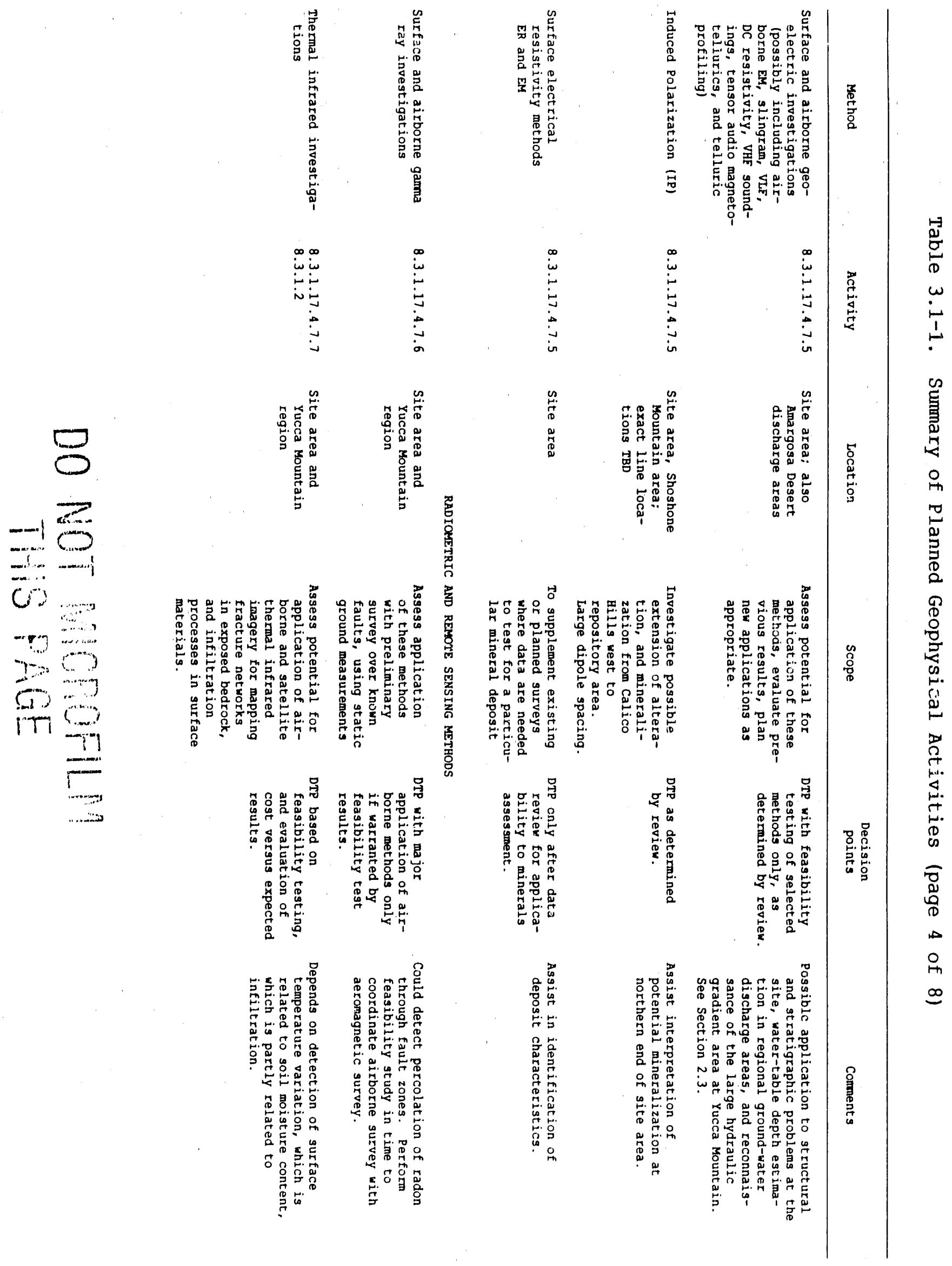




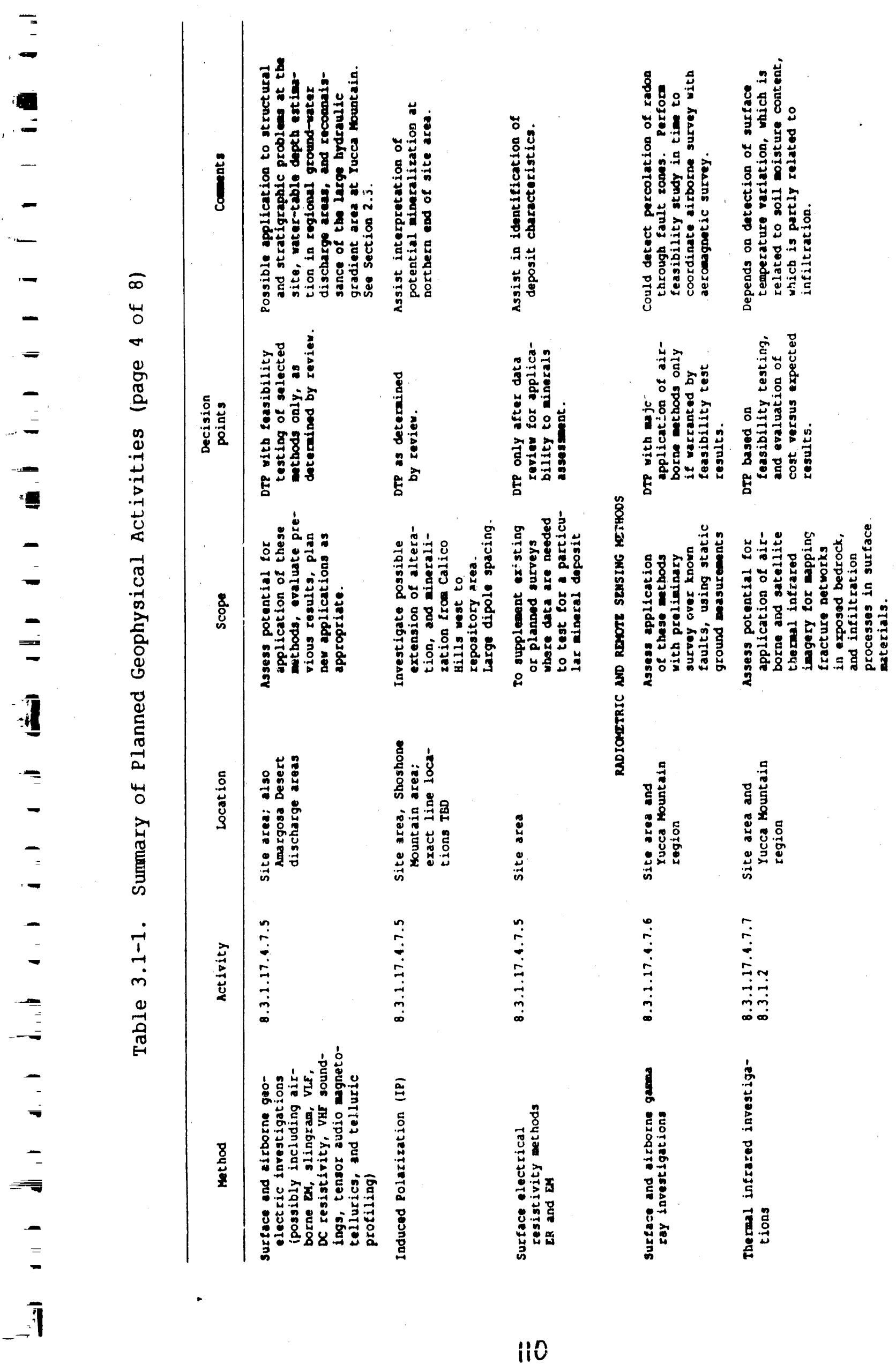




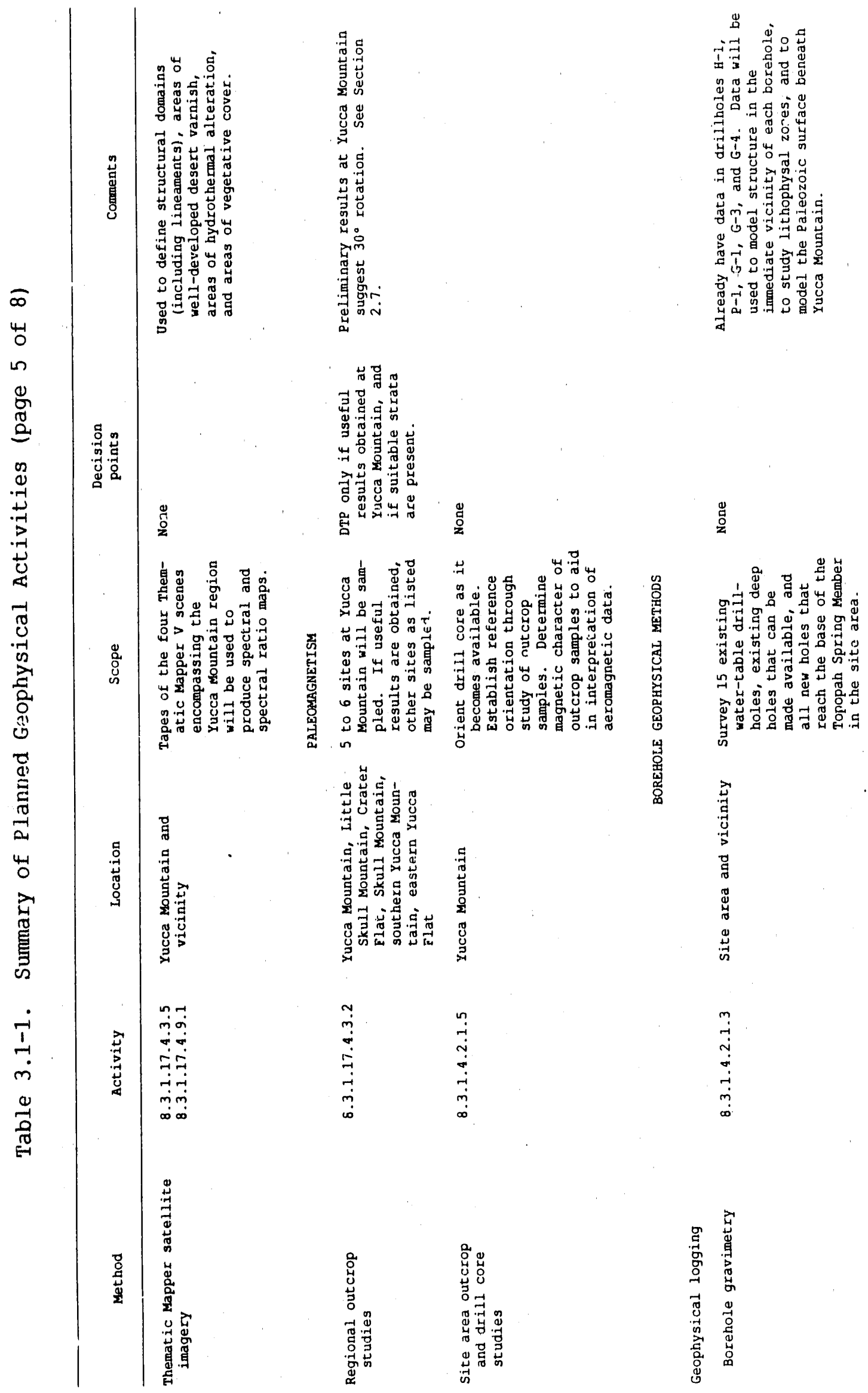




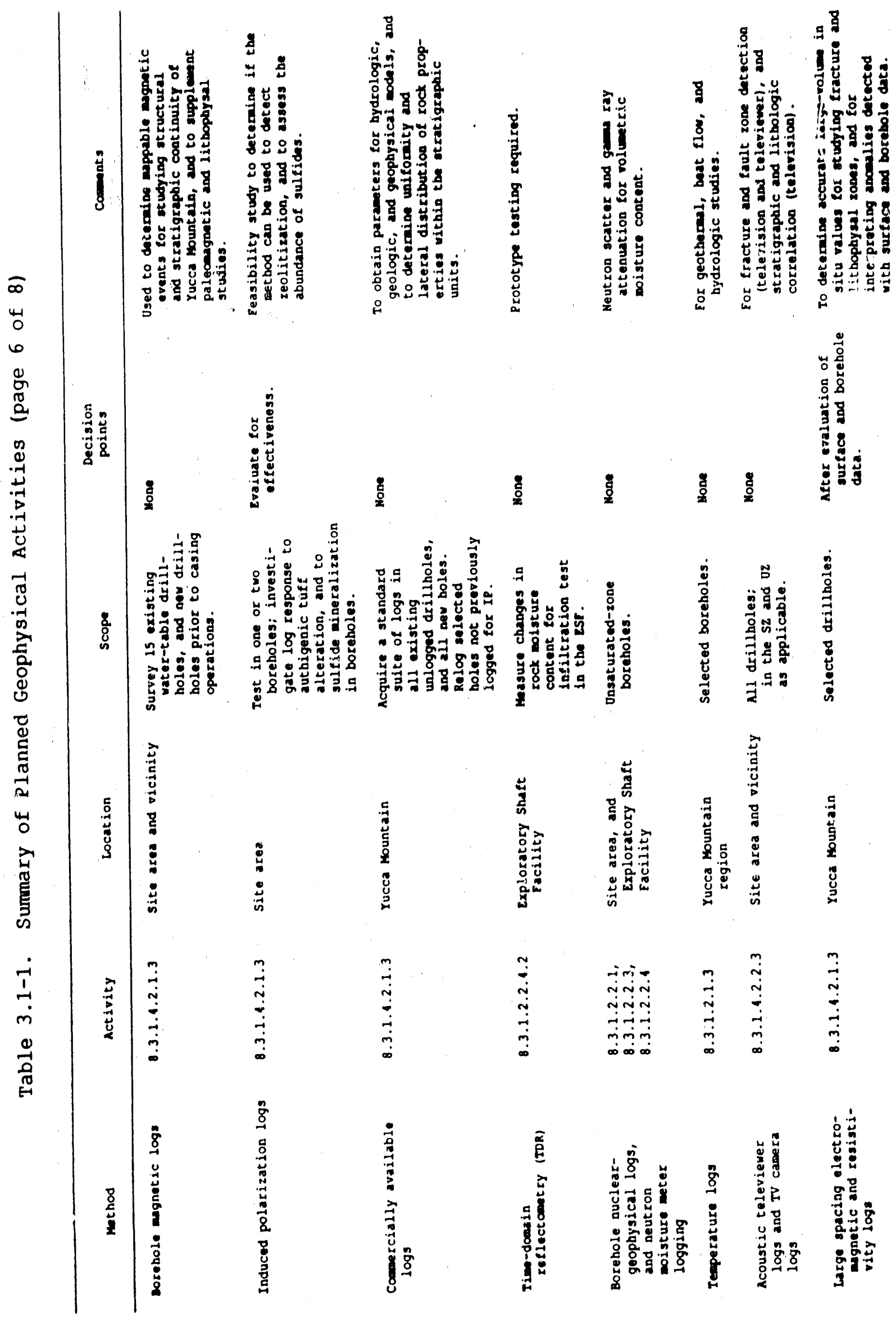




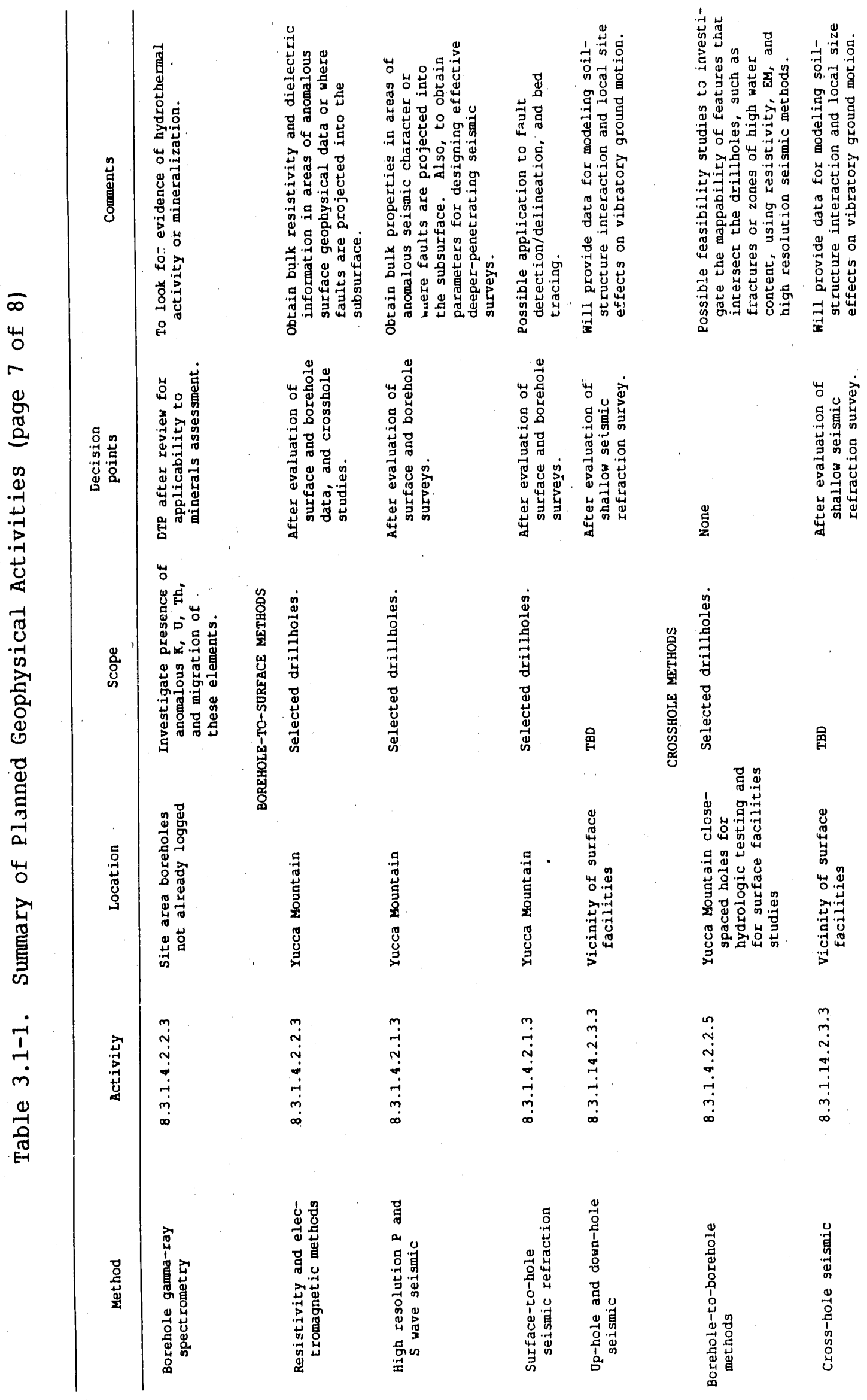




\subsection{DISCUSSION OF PLANNED GEOPHYSICAL ACTIVITIES}

\subsubsection{UNSATURATED ZONE HYDROLOGIC INVESTIGATIONS}

\section{FAR-FIELD CHARACTERISTICS FROM VERTICAL SEISMIC PROEILING (VSP)}

VSP will be tested early in the site program to determine its utility for characterizing variation in bulk fracture properties. It is thought that seismic methods may be capable of imaging large-scale (tens of meters) trends in average or bulk rock characteristics that are attributable to fracturing. Also, some features such as stratigraphic contacts or faults may be imaged as distinct seismic structures. Seismic profiles will be compared to results from pneumatic packer testing in boreholes and long-term monitoring of natural processes in the unsaturated zone (UZ), to evaluate the importance of observable seismic trends with respect to site behavior (Activity $8.3 .1 .2 .2 .3 .2)$.

The use of VSP for hydrologic studies is based on fundamertal models for seismic propagation in fractured rock. A system of near-vertical fractures tends to produce transverse anisotropy in compressional and shear wave responses. Velocity, anisotropy, and apparent attenuation will be interpreted in terms of contributions of fracturing to bulk deformability, or alternatively in terms of multiple scattering from distributed fracture interfaces. The surveys will be designed with coverage to support imaging with resolution as fine as about one seismic wavelength (which may be as smail as $20 \mathrm{~m}$ ). Consideration will be given to the structural fabric of the site to design surveys which can identify anisotropy or lateral heterogeneity of the seismic structure that may exist in proximity to known faults. Seismic sources will be evaluated using field trials and limited scoping studies; sources to be considered include shear vibrators, shear-impact sources, land air-gun, and explosives.

Two VSP experiments are currently planned: one at the Exploratory Shaft Facility (ESF), and another at the USW UZ-9 complex of UZ hydrology boreholes. The ESF study (SCP Activity 8.3.1.4.2.2.5) will require installation of three component geophones at intervals in the lining of each exploratory shaft, and along some workings at the main test level. Seismic data will be compared to the abundant information from geologic mapping and other testing in the ESF. In this way the relation between actual rock characteristics and seismic response will he evaluated in detail.

The USW UZ-9 compiex of boreholes will be constructed about $0.5 \mathrm{~km}$ southeast of the conceptual repository perimeter (Activity 8.3.1.2.2.3.2). These boreholes will investigate the Uz down to the water table. A prefabricated cable containing three component geophones at intervals of about $5 \mathrm{~m}$, to a depth of about $400 \mathrm{~m}$, will be cemented into a dedicated borehole. Present plans call for fully-cemented geophones to be used at the USW UZ-9 complex VSP borehole. The same method will be used in boreholes at other locations for Activity 8.3.1.2.2.3.2, in lieu of a wall-locking (removable) VSP tool, if it can be shown that fully-cemented geophones satisfy the study objectives reliably. Information on seismic characteristics (i.e., P- and S-velocities, velocity, anisotropy, apparent attenuation, and reflections) will be compared to information obtained from 
drilling, logging, and pneumatic testing in a cluster of Uz boreholes. Additional VSP surveys may be conducted at other locations in the site area (particularly USW UZ-6, and systematic drilling program boreholes) depending on the results from the initial tests at the ESF and at the USW UZ-9 borehole complex.

At present, no preliminary VSP data are available for Yucca Mu intain which would be of use in the design and planning of VSP studies in the ESF or at the USW UZ-9 complex. Simple downhole velocity surveys have been conducted using a single-component, wall-locking geophone tool and a vibrator source at zero offset. However, these data are available only on paper records, and are poorly suited for resolving velocity structure and evaluating attenuation and reflection coefficients. Physical model and computer simulations are being conducted using existing knowledge of structure and stratigraphy at the site, to support design of VSP experiments and reduction of data from the UZ-9 complex. This is an inportant topic for examination by the geophysical integration activity (SCP Section 8.3 .1 .4 .1 .21 .

FORMATION CHARACTERISTICS NEAR THE BOREHOLE, FROM GEOPHYSICAL LOGGING

A suite of geophysical wireline logs will be run in the UZ in each new borehole constructed at Yucca Mountain for percolation studies (Activity 8.3.1.2.2.3.2) and the systematic drilling program (Activity 8.3.1.4.3.1.1). A somewhat different suite of logs is intended for the saturated zone (SZ). The borehole geophysics activity (Activity 8.3.1.4.2.2.3) will involve logging of all new boreholes, limited relogging of existing boreholes, and development of lithostratigraphic and hydrologic interpretations.

Logs will be acquired in the UZ for lithology and mineralogy (density, gamma-ray, spectral gamma-ray, magnetic intensity, and magnetic susceptibility), fracture characterization (axial and side-view television), porosity (gamma density), and moisture detection (epithermal neutron, neutron moisture neter, dielectric). Logs acquired for moisture detection will be compared to moisture content and potential from core and cuttings testing (Activity 8.3.1.2.2.3.1), and to other moisture-sensitive information such as long-term in situ hydrologic monitoring (Actjvity 8.3.1.2.2.3.2). The logs are expected to provide information on moisture conditions during and after drilling, and changes in these conditions over time as the holes are tested, and stemned or shut-in.

Standard logs including caliper, temperature, and deviation surveys will also be acquired from the UZ. Although analysis of existing logs from Yucca Mountain is not yet complete, there is evidence that some of the common logs are not effective in the UZ. The compensated neutron porosity tool is of limited use in dry holes, apparently because of source-detector interference, which diminishes response to changes in formation moisture content (Serra, 1984). Also, the compensation algorithm may be unsuited for dry holes at the source-detector spacings commonly used. Experience at Yucca Mountain indicates better sensitivity to moisture content from single detector (shielded thermal detector) epithermal tools, used in non-centered configuration, than from standard compensated neutron porosity logs. 
Electrical logging methods are cummonly used to determine water saturation, but require some adaptation to the air-filled boreholes at Yucca Mountain. In the highly resistive $(>100 \mathrm{ohm}-\mathrm{m})$ tuffs of the Uz, particularly welded tuff, the induction $\log$ response is small and measurement uncertainty increases with increasing resistivity. If the inductive tool could be improved to provide reliable readings in the highly resistive UZ, then estimates of water saturation could be obtained. Another approach to determining water saturation is provided by the dielectric tool. Experience with a 47-MHz dielectric tool at Yucca Mountain shows that the log appears to respond to variations in water content with useful depth of investigation (e.g., $10 \mathrm{~cm}$ or more). This response requires substantiation with laboratory measurement of dielectric permittivity on cores of determined mineralngy and as a function of water content. In addition, the dielectric tool will be run in cored holes and compared to core-based measurement of water content. The feasibility of dielectric and induction logs, as well as the relatively new nuclear magnetic resonance $\mathrm{log}$, for moisture content in the UZ will be evaluated by a planned feasibility test of logging methods for UZ studies (see section 3.3 of this report).

The need for one or more calibration boreholes has been identified in relation to geophysical logging (Activity 8.3.1.4.2.1.3) and logging for surface infiltration studies (Activities 8.3.1.2.2.1.2 and 8.3.1.2.2.1.3). The objective is to have a facility where borehole geophysical logs can be rerun as necessary during site characterization, as a calibration check that takes into account effects not generally addressed by standard calibration procedures.

Dedicated calibration boreholes are also desirable for "benchmarking" the responses of tools that should produce similar logs (e.g., identical tools from the same manufacturer, or similar tools from different manufacturers). Existing boreholes and currently planued boreholes are either unsuitable or are committed to other uses.

The facility would be designed to stabilize formation characteristics, so that long-terin repeated logging would be expected to produce repeatable tool response. This and other aspects of calibration borehole design would be unique, and justify feasibility testing. Two holes, each about $30 \mathrm{~m}$ deep, have been tentatively proposed for the vicinity of Fran Ridge about $5 \mathrm{~km}$ east of the site. Each hole would sample the same part of the geologic section in a different hydrologic setting (e.g., rock slope and alluvium-covered wash). The ODEX dry drilling method would be used, and the holes could be completed with thin-wall steel, aluninum, or plastic casing over at least part of their length, to prevent them from gradually drying. Continuous core would be acquired using the dry method that was demonstrated in the existing shallow UZ holes (i.e., USW UZ-4: UZ-5, UZ-7, UZ-13). Core would be used for independent characterization of (1) lithology and hydrologic properties, and (2) baseline moisture conditions. Core data would provide a basis for inferring undisturbed conditions, which would be compared to log responses over time. Further design of the calibration borehole test will be addressed by the geophysics integration activity (see section 3.3 of this report). 
BOREHOLE, CROSSHOLE, AND SURFACE-TO-BOREHOLE METHODS

The crosshole gamma technique has been used on a preliminary basis for monitoring infiltration into the uppermost 2 to $10 \mathrm{~m}$ of soil or rock, in different settings at the site (SCP Activity 8.3.1.2.2.1.2). The limit for satisfactory transmission and detection of $0.66 \mathrm{Me} i$ gamma rays between steel-cased borings appears to be about 2 to $5 \mathrm{~m}$. These measurements continue to be made periodically for natural and artificial infiltration studies. The technique may also be used in the clustered USW UZ-9 boreholes. The spacing between boreholes in this cluster will be determined from the results of pneumat $c$ injectivity tests and observed fracture distribution, so that the intervering distance corresponds to a lineal dimension for a characteristic volume of the rock mass, if practicable. If this distance is approximately $5 \mathrm{~m}$ or less, then crosshole gamma attenuation data will be acquired from the adjacent boreholes. This survey will be run once, prior to installation of borehole instrumentation (as described in the SCP for Activity 8.3.1.2.2.3.2). Accordingly, high-accuracy information on the variation of inter-borehole distance is required to infer moisture content from the attenuation data. A high-precision (inertial) directional survey will be run in each of the adjacent boreholes to provide this information.

At the present time, borehole seisnic sources that can be used in dry holes have ranges that are limited to a few tens of meters. There are no immediate plans to attempt crosshole seismic surveys for UZ studies, but such surveys may be appropriate depending on the results from other techniques such as VSP.

A test of the feasibility of a number of borehole, surface-to-borehole, and possibly crosshole geophysical methods for characterizing fracturing and fault zones in the UZ and $S Z$ is proposed in section 3.3 of this report. This testing will be conducted using existing UZ boreholes, the existing "c-series" boreholes, or the proposed UZ-9 complex of boreholes, as appropriate. Methods identified for testing include large-spacing EM and ER logs, possible surface-to-borehole configuration of these methods, and possible crosshole VHF tomography (applicability of VHF methods is discussed further in Section 3.1.5).

\section{REMOTE SENSING}

Airborne thermal infrared imaging will be examined for its ability to detect the results of percolation of meteoric water through fractures, faults, or porous surficial units (Activity 8.3.1.17.4.7.7). Spatial or temporal surface-temperature anomaiies may be associated with differing moisture content of surficial or near-surface materials in response to precipitation or other moisture migration phenomena. Surface temperature can be detected from satellites and aircraft. This is a plannine activity only, involving scoping analysis and examination of existing data from the site and similar areas. Feasibility testing of airborne thermal infrared detection for UZ infiltration studies may be justified based on the results from this activity. 


\subsubsection{SATURATED ZONE HYDROLOGIC INVESTIGATIONS}

Geophysical surveys have been used in conjunction with hydrogeologic investigations for providing essential data used to construct and interpret the hydrogeologic framework of the ground-water flow system at yucca Mountain and vicinity. The principal advantages of geophysical surveys in this context are that geophysical data can reduce the need for drilling, and that large areas can be readily explored.

There are several special problems in characterizing the ground-water flow system, which may be addressed through the use of geophysical methods. These are (1) characterization of the cause and extent of the large hydraulic gradient area north of the site, (2) estimation of the amount and lateral extent of natural recharge occurring in Fortynile Wash east of Yucca Mountain and in other major washes, (3) characterizing the frequency and interconnectivity of fractures in tuff units at Yucca Mountain, and (4) characterizing the lithology and structure of Cenozoic and Paleozoic rocks in the regional ground-water flow system. Each of these problems is discussed below.

\section{EXPLORATION OF THE LARGE HYDRAULIC GRADIENT AREA}

A large hydraulic gradient $(300-\mathrm{m}$ head change in $2 \mathrm{~km}$ horizontal distance) has been identified from water level in drillholes to the north and west of Yucca Mountain (Robison, 1984; Robison et al., 1988), and from stem tests (e.g., Rush et al., 1983; Craig and Johnson, 1984). The cause of the gradient is unknown, but may be related to the following: (1) faults that contain nontransmissive gouge or that juxtapose transmissive tuff against nontransmissive tuff; (2) the presence of a different lithology that is less subject to fracturing, such as rhyolite or argillite, or the presence of an intrusive body such as a volcanic dike; (3) topography; or (4) a change in the direction of the regional stress field and a resultant change in the frequency, interconnectivity, and orientation of open fractures on either side of the large hydraulic gradient.

Several investigators have constructed models of ground-water flow of Yucca Mountain and vicinity, and in the process have relied to some degree on geophysical surveys to provide insight into the hydrogeologic framework of the hydrologic system. Perhaps the most comprehensive of these studies was that of Winograd and Thordarson (1975) in their report on the hydrogeologic and hydrochemical framework of the NTS. Their work relied on geologic characterization that, in turn, relied on geophysical surveys. Among those geophysical surveys was a regional gravity survey of the Death Valley region compiled by Mabey (1963)

The first numerical model of regional ground-water flow that includes Yucca Mountain was developed by Waddell (1982). This model provided the preliminary framework for the refined model of Czarnecki and Waddell (1984), which refers to extensive geophysical investigations of the NTS used for developing the conceptual model of the hydrologic system. Results from gravity and magnetic surveys are presented in Healey and Miller (1971), Kane et al. (1981), Ponce and Hanna (1982), and Snyder and Carr (1982). Resistivity studies of the area that were used in the model assessment were done by 
Smith et al. (1981), Fitterman (1982), and Greenhaus and Zablockj. (1982). Reconnaissance seismic-refraction studies were presented in Pankratz (1982). of these studies, gravity and magnetic surveys provicied the most useful information for delineating different lithologies, particularly for differentiating volcanic rocks from carbonate rocks. Geophysical ar.omalies in the large hydraulic gradient area were identified by the magnetic surveys reported by Bath and Jahren (1985), and the resistivity survey of Senterfit et al. (1982).

The water table does not appear to be a dependable target for direct detection by means of electrical, gravity, or seismic methods. Density and seismic velocity or impedance contrasts across the water table are small because the tuff matrix in the UZ contains significant water. Resistivity soundings and profiles reported by Frischknecht and Raab (1984), and Senterfit et al. (1982), suggest that the water table may be associated with a resistivity change from roughly 300 to 100 ohm-meters. However, the observed contrast is diffuse, and available methods appear to be sensitive to variability in near-surface materials, and other factors that make the water table contrast difficult to trace, and produce discrepancy with water level observations in boreholes. Although it is remotely conceivable to geophysicaliy map the water table in rugged terrain north of the site with borehole control, this type of information still might not reveal the cause of the large hydraulic gradient. Exploration will therefore emphasize reconnaissance for geophysical detection of geologic features giving rise to the gradient, which is potentially a more straightforward exploration problem.

A preliminary scoping analysis of the use of detailed gravity data for investigating the large hydraulic gradient has been performed (H.W. Oliver and S.F. Carle, written communication). Existing gravity data covering the area northwest of the site area were examined for correlaticn with the potentiometric surface, and for the presence of a structure affecting the potentiometric surface. Gravity data collected along Drill Hole Wash and along a parallel northwest-southeast profile were modeled in two dimensions. The resulting density model was adjusted for agreement of calculated gravity with observed gravity. This could be accomplished by including offsets for a number of known faults crossed by the profile, and by adjusting the thickness of the oldest tuff units and the depth to the Paleozoic-Tertiary contact. Thus the existing gravity data appear to correlate to deep structure and are probably not significantly affected by the potentiometric surface or structure with similar geometry. The feasibility of using gravity data that are more detailed than the existing data, for investigation of the large hydraulic gradient, will be examined in a proposed feasibility test wherein detailed data will be acquired along northwest profiles across the large hydraulic gradient area (see Section 3.3 of this report). The location of these profiles will roughly coincide with the magnetotelluric profiles shown in Figure 3.1-1, depending on the details of available elevation control in this area.

Another gravity method that will be considered and possibly tested in the field is high-resolution temporal gravity monitoring by means of a cryogenic-type gravimeter. This instrünent can resolve $10^{-1}$ pgal $\left(10^{-10} \mathrm{~g}\right)$, with drift of about $10 \mu \mathrm{gal}\left(10^{-8} \mathrm{~g}\right)$ per year. One objective for gravity monitoring would be to correlate water well level observations with 


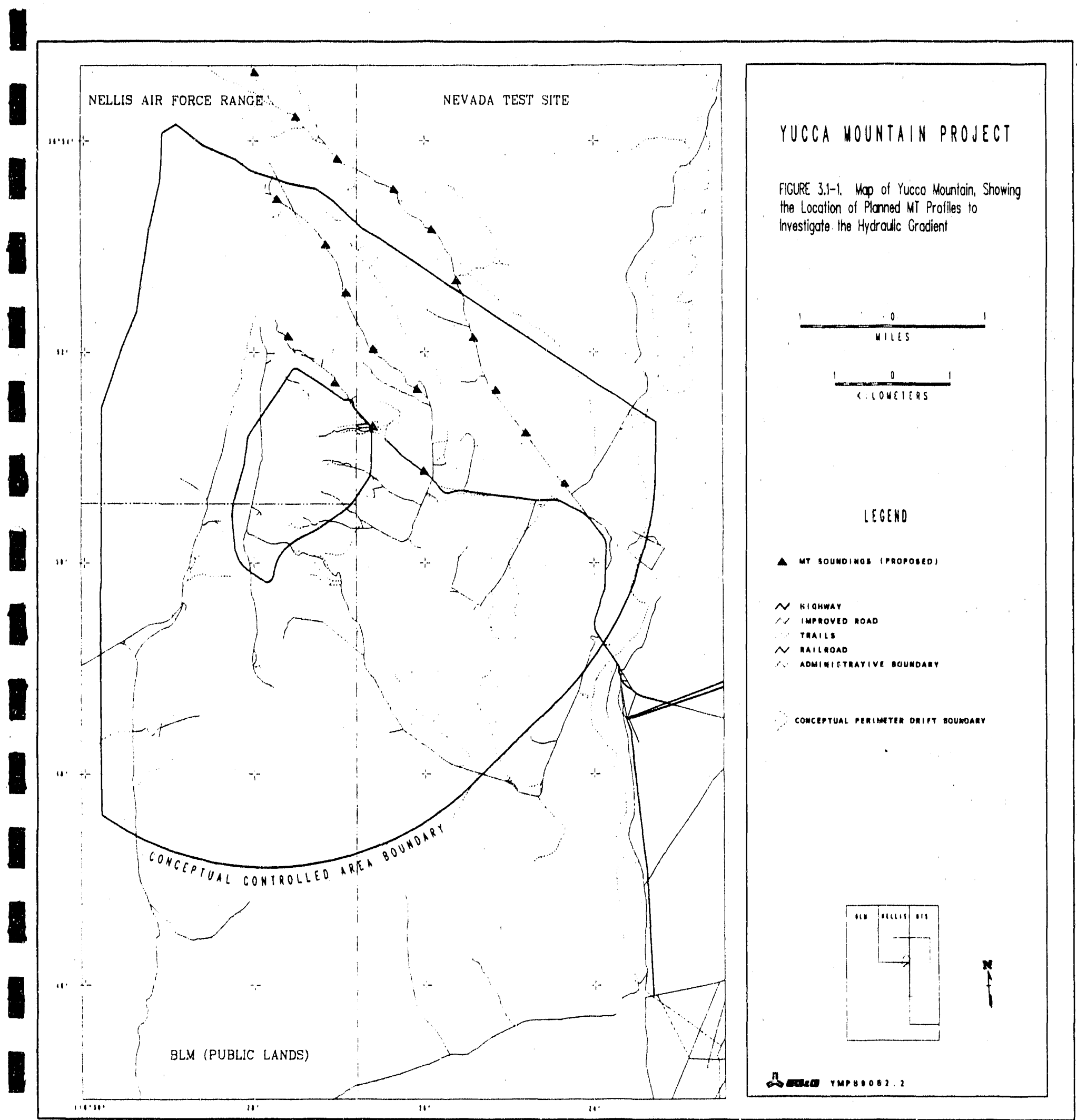


atmospheric fluctuations, tidal acceleration, earth tides, and other geophysical phenomena at the site. Another application would be comparison of continuous gravity recordings with theoretical models for gravity signals that might result from active processes such as rising magma or fault slip. The applicability of continuous gravity monitoring with cryogenic-type gravimeters (as well as by other means) will be evaluated in a scoping study of geophysical monitoring capabilities and application (see section 3.3 of this report).

The deep structure which is apparently the cause of a gravity anomaly of 8 to $10 \mathrm{mgal}$ beneath the northern portion of Yucca Mountain (see Section 2.1) is roughly associated with a gradient in total aeromagnetic intensity, in the vicinity of the large hydraulic gradient (see Section 2.2). Planned detailed gravity and detailed aeromagnetic surveys will encompass this area for reconnaissance, and enable further modeling and interpretation (SCP Activities 8.3.1.17.4.\%.2 and 8.3.1.17.4.7.4, respectively). The geophysics integration activity will ensure through planning and interaction between investigators that detailed gravity and aeromagnetic surveys (see Activities 8.3.1.17.4.7.2 and 8.3.1.17.4.7.4) are appropriate for reconnaissance of the large hydraulic gradient area.

A program of closely spaced magnetotelluric and audio-magnetotelluric soundings, oriented along northwest profiles across the large hydraulic gradient, has been proposed as a feasibility test. The objectives will be to detect large scaie structures, and lithologic changes (as manifested in electrical resistivity variation), that may be associated with the cause of the large hydraulic gradient (see section 3.3 of this report). The frequency band used will be approwimately 0.01 to $100 \mathrm{~Hz}$, which is sensitive to resistivity contrast in the upper $3 \mathrm{~km}$. Current plans call for 20 fivecomponent soundings at the locations shown on Figure 3.1-1. The response of orthogonal MT components will be used to evaluate changes in apparent resistivity anisotropy, and to correlate such changes with known geologic information to identify possible anomalies that could indicate structure or facies changes that may give rise to the large hydraulic gradient. The planned program of MT soundings is subject to the review of geoelectric methods that is also planned (Activity 8.3.1.17.4.7.5). Current plans call for the review prior to additional field surveys.

Data from the following surveys, described in various parts of the SCP as noted, will also be analyzed to characterize the large gradient area, and to identify anomalies that may be associated with the cause of the gradient and identify targets for driliing or more intensive geophysical exploration. These activities are mostly planned in conjunction with geology and tectonics studies:

1. Mini-Sosie seismic reflection surveys (Activity 8.3.1.4.2.1.2).

2. Analysis of in situ stress information obtained from fracture indications recorded by the borehole acoustic televiewer (Activity $8.3 .1,42.2 .3)$.

3. Ground magnetic surveys (Activity 8.3.1.17.4.7.3). 
4. Upper-crustal high-resolution seismic refraction (Activity 8.3 .1 .4 .2 .1 .21 .

These methods will be applied along traverses oriented to test specific hypotheses related to formation of the large gradient, including the existence of a major lateral discontinuity in buried Paleozoic rocks, a buried fault, or an igneous intrusion. This work will be done in a relatively roadless area with rugged terrain. Application of seismic reflection will depend on testing and evaluation that is planned for other locations (see section 3.1.4).

In sumnary, application of geophysics to study of the large hydraulic gradient area involves feasibility testing, and integration with other planned geophysical testing and exploration activities. Coordination between technical groups and Project participants applying and using information from geophysical surveys is the function of the planned geophysics integration activity.

\section{INVESTIGATION OF RECHARGE IN STREAM WASHES}

Recharge occurring in Fortymile wash and other washes in the vicinity of the site area is probably the major component of water movement through the $\mathrm{IT}$ to the SZ in the vicinity of Yucca Mountain. Recharge has been documented in Pagany wash through repeated soil moisture logging in specially constructed boreholes (see Section 2.7). Czarnecki (1985) showed from modeling of the subregional ground-water flow system that the water table altitude beneath the site area is more sensitive to the nature of recharge at Fortymile Wash than to other recharge parameters used in the model.

Factors affecting recharge (net infiltration) include (1) thickness and permeability of unsaturated channel fill or alluvium; (2) the presence of impermeable strata such as caliche within alluvial sediments; (3) the presence of vertical, open fractures beneath the channel surface; and (4) ambient soil moisture content.

The thickness of channel fill will be measured directly by a number of borings. Geophysical methods will be used to the extent feasible, to detail the depth to bedrock in the vicinity of borings, and for reconnaissance. Available methods include (1) seismic refraction of the type reported by Hasbrouck (1987, 1988) and Pankratz (1982) for shallow and intermediatedepth contacts, respectively; (2) high-resolution gravity profiling across features such as Fortymile Wash (Oliver, personal communication, 1989); and (3) reflection surveys such as that reported by Brocher (1989) for deeper targets. A simple shallow refraction method has been tested for this purpose in the site area (A. Flint, personal communication) with success up to a few tens of meters depth. Planned reviews of seismic and electrical methods (Activities 8.3.1.17.4.7.1 and 8.3.1.17.4.7.5) will address the objective of sounding depth to bedrock.

To gain a better understanding of the hydrogeologic framework of the Amargosa Desert, Czarnecki and Oatfield (1987) compared estimated depth to bedrock from Schlumberger resistivity soundings (Greenhaus and Zablocki, 
1982) to the estimates from gravity interpretation for the region (Healey and Miller, 1971), and the seismic refraction lines discussed by Ackermann et al. (in USGS, 1988). Depth to bedrock was estimated by Greenhaus and Zablocki (1982) to be as much as $1,800 \mathrm{~m}$ in parts of the Amargosa Desert. Relative differences in resistivity of the upper $75 \mathrm{~m}$ of sediments were used in conjunction with lithologic descriptions from test borings and irrigation wells to identify areas with coarser and potentially more transmissive sediment. The resulting alluvial thickness model is important and will be used in ongoing numerical models of the ground-water flow system. Past results indicate that the approach to mapping alluvial thickness from resistivity, gravity, and seismic refraction data could be applied north of the Amargosa Desert in areas such as Fortymile Wash and Jackass Flats. Existing gravity data (Section 2.1) and an east-west upper-crustal seismic refraction profile (Sutton, 1985; also see Section 2.4) are available for this region.

Detecting the presence of impermeable strata in borings within the valley fill may best be accomplished by coring, but in lieu of this procedure borehole geophysical logging will be used. This method has been applied at Yucca Mountain, using a neutron moisture meter tool in a steel-cased boring. The distribution of moisture following recharge events can be used to identify and infer the hydrologic behavior of stratigraphic features. This approach is less costly than coring, and has detected infiltration to as much as $12 \mathrm{~m}$ depth (see Section 2.7). The same methodology would be used in major recharge areas such as Fortymile Wash, but extended to depths of hundreds of meters. Development work is ongoing to improve neutron moisture logging tool response and calibration. The logging approach also permits repeated measurements during possible recharge events.

\section{FRACTURE CHARACTERIZATION IN THE SATURATED ZONE}

Ground-water flow through Tertiary volcanic units in the Sz at Yucca Mountain is probably dominated by the effects of fractures, and moisture movement through the $\mathrm{UZ}$ may be dominated by fractures depending on the moisture flux.

Fracture data will be used in the interpretation of falling-head injection tests and other hydraulic-stress tests previously conducted at the existing "c-series" boreholes (SCP Activity 8.3.1.2.3.1.3). Fracture data will be used in conjunction with interborehole flow tests to select combinations of test intervals for multi-well interference tests (SCP Activity 8.3.1.2.3.1.4) and tracer tests (see SCP Activity 8.3.1.2.3.1.5). Fracture network models (SCP Activity 8.3.1.2.3.1.4) used to interpret the results of multi-well tests will be based partly on borehole logs and (to the extent practicable) the results of crosshole and surface-to-borehole geophysical surveys.

Fracture characteristics that principally affect ground-water mobility are spatial distribution, frequency, length, connectivity, and transmissivity. Of these, distribution and frequency can be characterized geophysically. Length and connectivity are geometric characteristics for which geophysical methods provide useful information only in the unusual case 
that geophysical responses of individual fractures can be recognized. Measurement of transmissivity requires a hydraulic test to induce fluid transport, with measurement of induced fiow or potential. Electrical current might be substituted as an indicator of hydraulic response, to the extent that current flows along the same pathways, and sufficient resistivity contrast exists between the fractures and the rock matrix. This possibility will be tested during prototype testing early in site characterizarion, as discussed below.

Fracture data obtained prior to site characterization by borehole geophysical logging of the $\mathrm{SZ}$ in the "c-series" boreholes, and other boreholes at Yucca Mountain, will be used in several hydrologic investigations, Borehole television, the borehole acoustic televiewer (BATV), and the full waveform acoustic log (FWAL) will be used to obtain fracture frequency and fracture attitude in the Sz (Activity 8.3.1.4.2.2.3). Fracture information from limited available core, and lithologic information from cuttings, will also be used.

Fractures are difficult to characterize from vertical boreholes because most fractures in the tuff units are nearly vertical. Additional information on fracture characteristics in the vicinity of boreholes would be useful to evaluate the bias inherent to borehole observation. Several geophysical methods are planned to characterize the spatial variability of fracture characteristics on a volume average basis throughout the rock mass near certain existing exploratory boreholes. Feasibility testing (see section 3.3 of this report) will be performed in both the UZ and SZ, using existing borehole USW G-4, the existing "c-series" boreholes (spaced about $60 \mathrm{~m}$ apart), and the planned USW UZ-9 cluster (spaced roughly 5 to $20 \mathrm{~m}$ apart). Tests will assess the capability tc trace features that are observed to intersect the boreholes. Based on the results, the following methods may be extended to other boreholes in the site area for characterization of fractures in the SZ: (1) conventional and shear-wave VSP, (2) large-spacing $E R$ and $E M$ borehole logs, (3) surface-to-borehole measurements designed to extend the borehole surveys, and (4) crosshole VHF tomography.

The hydrophone-VSP method (e.g., Beydoun et al., 1984) for detecting transmissive fractures by means of tube wave generation in the $S Z$ will be considered as a candidate method for feasibility testing. Performance of the method depends on the availability of a suitable seismic source. A broad-band source is needed that can penetrate the rock mass intervening between the source point (e.g., at the surface) and fracture intersections with the well bore in the Sz.

\section{REGIONAI CHARACTERIZATION OF CENOZOIC AND PALEOZOIC ROCKS}

For the purpose of characterizing regional ground-water flow, more information is needed about the depth to top, thickness, and areal distribution of pre-Tertiary rocks. One borehole (UE25 p\#1) penetrates the pre-Tertiary section at Yucca Mountain at a depth of $1,244 \mathrm{~m}$. Because of the information needed for regional hydrologic characterization, and the expense of deep drilling, geophysical methods are needed to characterice subsurface 
structure, particularly of the Paleozoic section where it is buried beneath the Tertiary cover.

Recent seismic refraction surveys (Ackermann et al. in USGS, 1988) have provided reasonably good definition of pre-Tertiary units in the Yucca Mountain area, but these surveys do not cover the entire area of interest for regional hydrology. Magnetic surveys (e.g., Bath and Jahren, 1984) and gravity surveys (Ponce, 1981; Snyder and Carr, 1982) have provided additional information on the structure of Tertiary and pre-Tertiary units. While not decisive in determining either geometry or lithology, or regional distribution of Paleozoic rocks, these results provide some basis of the necessary information needed to characterize the regional ground-water flow system framework. Additional geophysical surveys will provide useful data for defining the regional hydrogeologic framework in the vicinity of the site.

The objectives of geophysical surveys associated with regional sz studies are (1) to determine the areal distribution of thickness of Quaternary and Tertiary rocks in the vicinity of the site; (2) to determine the areal distribution, depth to top, and thickness of paleozoic rocks in the vicinity of the site; and (3) to determine the structural configuration of the rocks in the regional ground-water flow system, including the nature of the contact between Tertiary and Paleozoic rocks. Plans to achieve these objectives are several fold. One possibility includes expansion of the currently existing seismic refraction surveys previously discussed in Section 2.4 and Figure 2.4-2 of this report. Such expansion would include two or three new east-west lines crossing the Ash Meadows and Amargosa River lineaments, and extensions of the existing reflection and refraction lines for more complete coverage of the regional ground-water flow system (Figure 3.1-2). Gravity, magnetic, and resistivity surveys are recommended within a 5-km-wide zone coincident with both reflection and refraction lines. Finally, supplemental gravity, magnetic, and geoelectric surveys are needed where gaps in coverage exist. Coordination for design of the geophysical surveys, with respect to Sz hydrology studies, will be undertaken by the geophysics integration activity (SCP Section 8.3.1.4.1.2).

\subsubsection{GEORHYSICAI CHARACTERIZATION OF MINERAL AND ENERGY RESOURCES}

Application of geophysics to mineral resource assessment will be closely integrated with corresponding geological and geochemical studies throughout the assessment process. Geophysical data have relevance at all scales of investigation, from the regional (for identification of favorable terranes and large structures) to deposit-scale and borehole geophysics. Geophysical methods provide direct and indirect measurement of a wide range of physical properties or contrasts, and are a necessary complement to geologic and geochemical studies.

There are relatively few geophysical methods which directly detect particular types of mineral deposits. Gamma-ray spectrometry for uranium is a notable example, if the deposit is near the surface or intercepted by a borehole. Induced polarization for sulfide mineralization is another example of direct detection. However, most other methods provide only indirect 


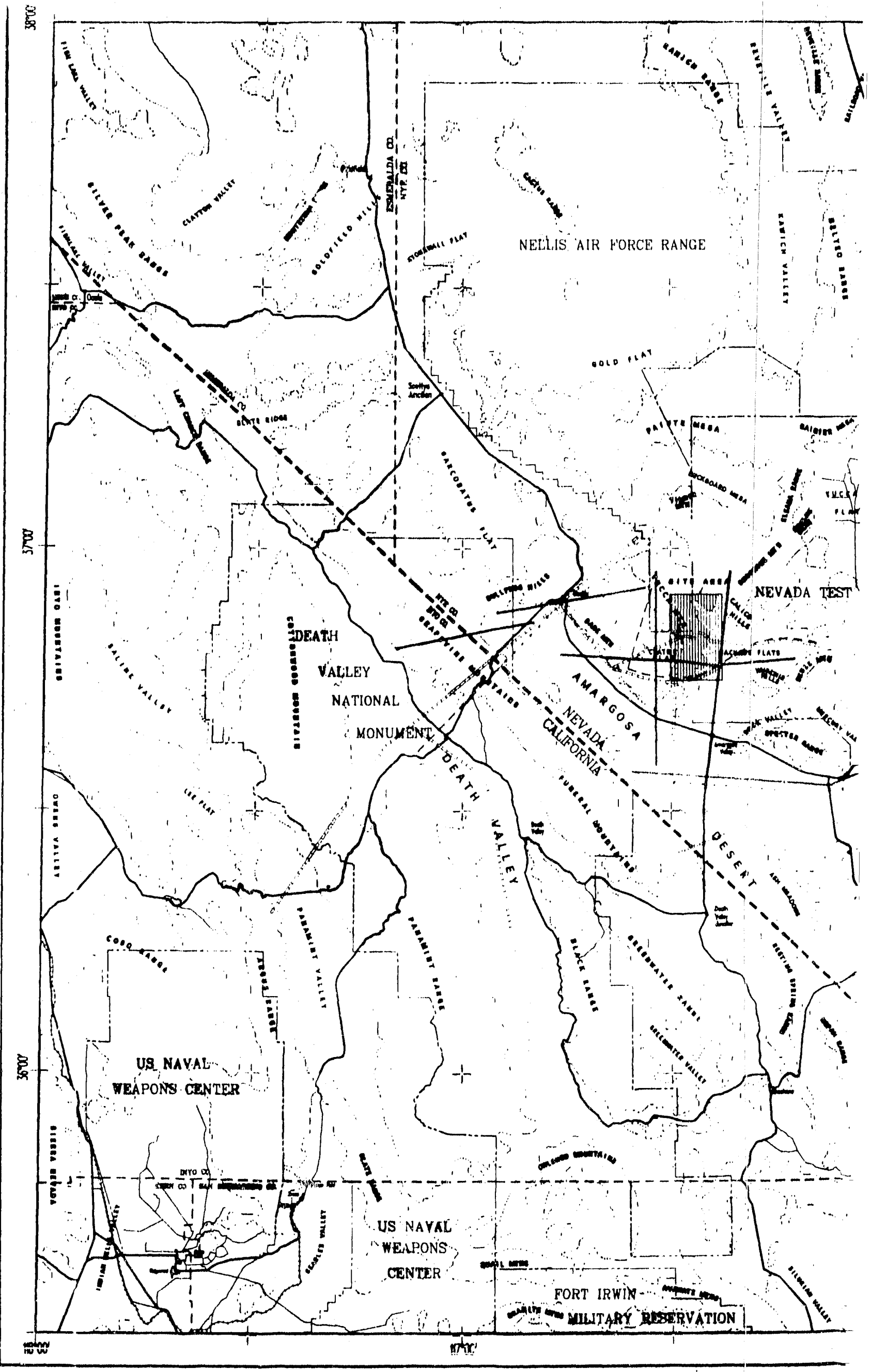




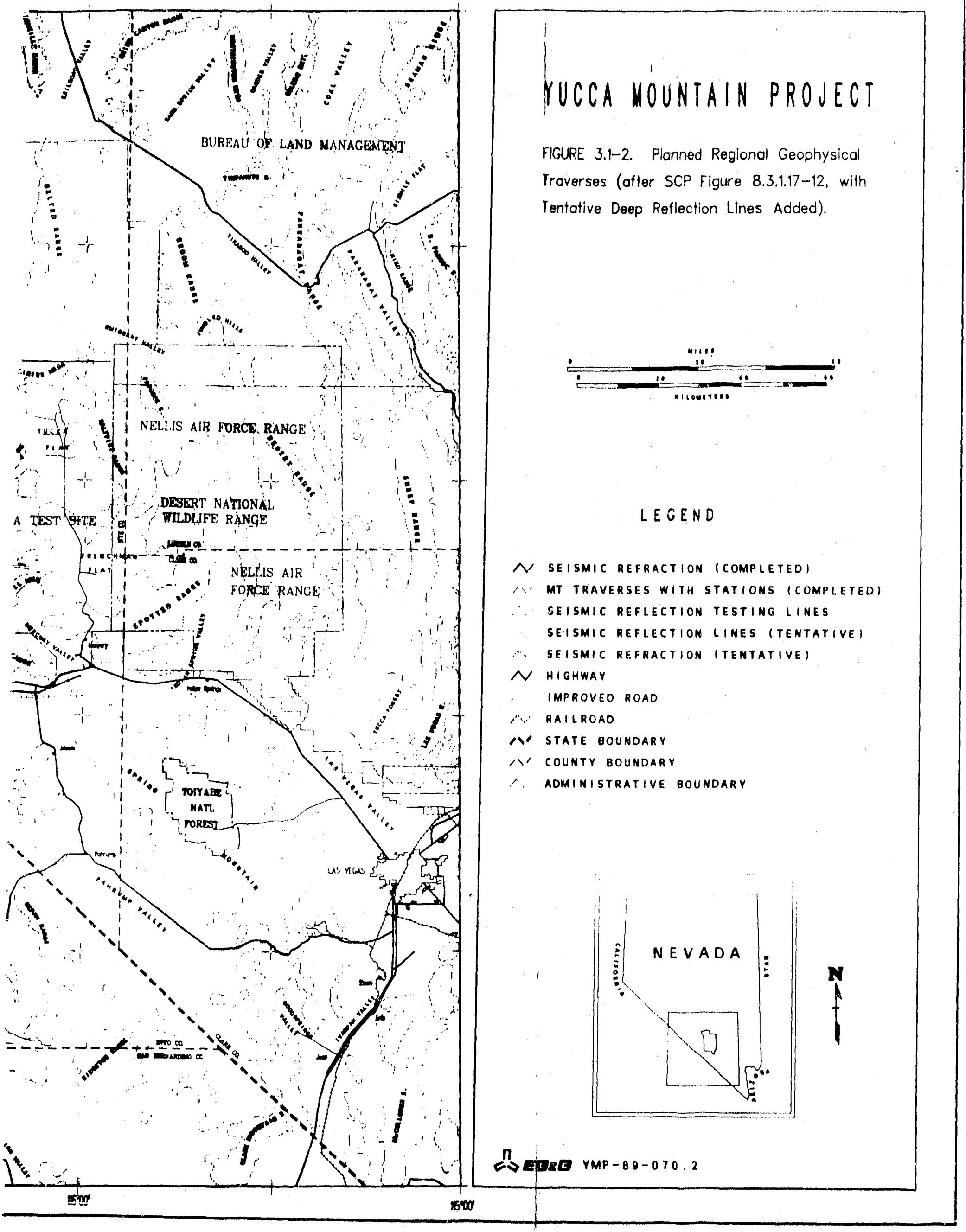


evidence for the presence of mineral deposits, which when combined with geological and geochemical information, can identify terrains or regions where the probability of mineral occurrence is favorable. Geophysics can identify structures, lithologies, alteration, the presence of some mineral groups (iron oxides, sulfides, clays, zeolites, etc.), radioactive elements ( $\mathrm{X}, \mathrm{U}, \mathrm{Th})$, and density anomalies, which may then be used indirectly to infer potential mineralization. Geophysical methods are especially important at Yucca Mountain because significant mineralization, if present, is probably below the volcanic units.

Modern assessment and exploration work is being aided by the generation of genetic and descriptive mineral deposit models. Descriptive models such as those presented by Cox and Singer (1986) are believed to contain the essential descriptive features of various kinds of deposits, but do not necessarily reflect genetic parameters. These models, as well as grade-tonnage models, will play an important part in the assessinent of mineral and energy resources at Yucca Mountain. Descriptive models published to date contain limited information on geophysical attributes of the individual deposit models. However, a number of geophysical attributes have been identified for many deposit types. The USGS is beginning to correlate geophysical attributes with other mineral deposit parameters in order to improve the utility of descriptive models for assessment of resources at Yucca Mountain.

Deposit models, which include geophysical attributes once developed, will support quantitative evaluation of the geophysical methods for reconnaissance (i.e., gravity and magnetic surveys, seismic and geoelectric profiling, and remote sensing) and for detailed investigation of suspected targets. Additional geophysical data, if needed, will be acquired as part of existing geophysical activities planned or used as a basis for new activities in association with the geophysics integration activity (SCR Sect: $n$ $8.3 .1 .4 .1 .2)$.

Methods used in minerals assessment are similar to those used in other site characterization investigations. Resource assessment can use results from a number of planned geophysical activities and interpret them in terms of potential mineral deposits. For example, borehole logs acquired principally as lithostratigraphic indicators will be inspected for the remnants of hydrothermal systems. Subsequent investigations would focus on particular mineralization processes or types of deposits.

There are significant problems with identifying high-valuu, small-volume deposits which might be present in Paleozoic units below the volcanic section at Yucca Mountain. Surface or airborne geophysical surveys may not detect small deposits beneath the thick volcanic section, and only one drilihole at Yucca Mountain presently penetrates through the volcanic sequence. Sampling and geophysical logs from existing and planned deep drillholes will be used to the extent practicable.

Structural/stratigraphic studies as discussed below for geology and tectonics, will also be applied to mineral and energy resource assessment. such information will support evaluation of the resource potential of faults and other structures; evaluation of traps, seals and reservoirs; and comparison of structure to that at known resource occurrences in the Great 
Basin of Nevada (SCP ACtivity 8.3.1.9.2.1.4). (These evaluations will also rely on other data such as geochemical analysis, source rock evaluation, thermal maturation studies, etc.) Requirements for geophysical exploration related to evaluation of mineral and energy resources evaluation will be addressed in the geophysics integration activity (SCP Section 8.3.1.4.1.2).

Opportunity to combine refraction and reflection surveys will be considered in planning the regional geophysical lines. The refraction lines will be acquired using programmed remote recorders, distributed over a distance that is much larger than a typical reflection spread. The number of large (e.g., $1000 \mathrm{~kg}$ ) explosive shots available for refraction survey is limited, so possibilities for piggy-backing surveys are limited. Data from previous refraction surveys (described in Section 2.4) suggest that under certain conditions useful records could be obtained from a long reflection-type geophone spread during a typical refraction experiment. To be useful for site characterization, the spread would need to be layed out over a refraction objective, proximal to shot points, when the refraction survey is performed.

Additional boreholes may prove necessary for mineral or energy resource assessment. Deep boreholes are not currently planned because specific site information is unavailable. Geophysics will contribute to siting decisions should the need arise, as addressed by the geophysics integration activity (SCP Section 8.3.1.4.1.2).

\subsubsection{GEOPHYSICAL STUDIES FOR GEOLOGY AND TECTONICS}

\section{REGIONAL GEOPHYSICAL STUDIES}

Study of geologic structure and tectonic processes in the Yucca Mountain region contributes to the development of tectonic models. Geophysical data will be used for evaluation of alternate hypotheses of past and present processes which have formed, and continue to affect the Yucca Mountain site. Use of regional geophysical data will involve comparison of the site area to terranes with known tectonic style and rate of activity, and direct investigation for the occurrence of features that could be important with respect to site performance. The product, a developed model for regional tectonics, is needed to assess the potential for ground motion, volcanism, magmatic activity, and faulting that could affect the design or the performance of repository facilities.

Regional geophysical studies involve deep surveys utilizing seismic, gravity, magnetic, and magnetotelluric methods for study of major structures (SCP Activity 8.3.1.17.4.3.1), and also characterization of faulting from surface indications by means of remote sensing, gamma-ray surveys, and other techniques (Activity 8.3.1.17.4.3.5). (Note that regional gravity and aeromagnetic mapping has already been done as described in Sections 2.1 and 2.2, respectively.) The following sumary of regional geophysics refers to features and alternative models that are discussed in SCP Section 8.3.1.17.4.3; the reader is referred there for additional detail. 
The regional geophysical exploration program is designed to acquire specific types of data (i.e., seismic, geoelectric, gravity, magnetic, remote sensing), which will be analyzed with other geophysical data (i.e., heat flow, stress), surface geologic dara, and recorded seismicizy.

Several geophysical transects are planned to cross the Furnace Creek fault, Walker Iane, and Yucca Mountain (Eigure 3.1-2). The objectives for these regional geophysical lines, as explained in SC? Section 8.3.1.17.4.3.1, include investigation of the following:

1. Width and subsurface geometzy of extensions of the Furnace Creek fault zone.

2. The possibility of an incipient rift at Crater Flat.

3. The relation of the Furnace Creek fault zone and othe $=$ features to detachment faulting and Quaternary faulting in the vicinizy of the site.

4. Lateral heterogeneity of crustal structure in the Yucca Mountain area.

5. The relation of density, magnetic, and geoelectric structure with velocity structire for the Yucca Mountain region.

6. Possible magma bodies in the vicinity of Yucca Mountain (see a.lso Activity 8.3.1.8.1.1.3).

The description for SCP Activity 8.3.1.17.4.3.1 presents a compact sumary of regional geophysical methods to be applied along regional traverses, which is further summarized below. Seismic refracsion profiles will be used with gravity and magnetic lines to characterize upper-crustai structure in the Yucca Mountain area, and to identify major discontinuities in that structure. Refraction work is planned to complete a major east-west traverse across Yucca Mountain, and two intersecting north-south lines in the site vicinity (Eigure 3.1-2). Existing seismic refraction data provide some evidence for the presence of a low-angle velocity contrast, possibly a detachment fault, extending from the Grapevine Mountains to the Yucca Mountain region. Detachment faults are believed to accommodate Cenozoic crustal extension of at least $100 \%$ in the Yucca Mountain region (Hamilton, in USGS, 1988). The existing high-resolution refraction data (Section 2.1) pertain mosty to the upper $4-5 \mathrm{~km}$, which may be above the depth of detachment beneath Yucca Mountain. Additional, longer profiles are needed to follow faults into the Yucca Mountain region from exposure in the Grapevine and Funeral Mountains. Preliminary results from the southwest end of the Beatty profile (Figure 2.4-2) are encouraging, but this was a reconnaissance profile and is incomplete. Planned refraction lines will extend fuliy between Deach Valley and the site area.

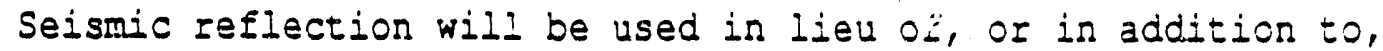
refraction and potential-field methods where higher resolution is required. Results from several recent reflection surveys of different types (Kruepfer 
et al., 1987; Serpa et al., 1986; Brocher et al., 1989) indicate that structural features of importance to tectonic assessment of Yucca Mountain can be imaged (see Section 2.5). The method will be applied to features of interest, including (1) a 6-sec (two-way travel time) reflection in Death Valley that was interpreted as a brittle-ductile transition (devoord et al., 1936); (2) the subsurface extension of parallel northwest trending faults in the northern part of the Walker Lane (west-central Nevada), the Furnace Creek fault zone, Walker Lane; (3) a mylonitic detachment bounding the upper surface of the Precambrian rocks exposed in the northern part of the Amargosa Desert; and (4) the Paleozoic-Miocene contact. Based on peer review of the reflection feasibility test results (Activity 8.3.1.17.4.3.1) and the application of the planned regional traverses to site characterization, the method reported by Brocher et al. (1989), supplemented by gravity and magnetic profiling, will be used to characterize selected features that could be associated with significant ground motion, rupture, and magmatism within $100 \mathrm{~km}$ of the site. Current plans call for two east-west reflection lines crossing Yucca Mountain at the site area, and possibly another lire extending from Death Valley across the Walker Lane to the vicinity of Yucca inountain (Figures $3.1-2,-3$, and -4 ).

Magnetotelluric soundings in the Yucca Mountain region indicate substantial conductivity contrasts between Precambrian crystalline rocks, Paleozoic aquifers and aquitards, argillaceous Paleozoic units, Miocene volcanics, and Quaternary basin fill. The method permits local characterization of gross features of crustal structure at low cost. Planned traverses will coincide with the refraction, gravity, and magnetics traverses described above, with additional intersecting traverses (Figure 3.1-2). In addition, a reconnaissance profile at larger spacing between soundings will extend from southern Death Valley where COCORP lines were located (Serpa et al., 1988; deVoogd et al., 1986) northward to Yucca Mountain.

\section{Detection/Characterization of Faults in the Yucca Mountain Region}

Regional tectonic studies as planned in the SCP will focus on the relationship of the Death Valley-Furnace Creek fault zone and the Walker lane to the Yucca Mountain site, but other potentially significant Quaternary faults lie within $100 \mathrm{~km}$ of the site. Because of the intensity of previous geologic investigations near the site, the density of known Quaternary faults there exceeds that for the surrounding region. A wide range of geophysical methods have been proposed to obtain more representative data on faulting within $100 \mathrm{~km}$ of the repository site, as indicated in Table 3.1-1. Each method has the potential to contribute interpretable information, but cartain methods have been demonstrated to be more effective than others as indicated in the table by different plans for implementation.

Faulting within $100 \mathrm{~km}$ of the site will be characterized by review of existing data, air-photo interpretation, and ground reconnaissance. Also, evaluation of structural domains within the $100 \mathrm{~km}$ distance is the objective of Activity 8.3.1.17.4.3.5, whereby Landsat $V$ thematic mapper imagery will be purchased for the quadrangles covering the Yucca Mountain region. These images will be analyzed for evidence of lineaments that may be associated with concealed faults and fracture patterns, and for evidence of hydrothernal deposits associated with igneous activity. The same thematic mapper data set 


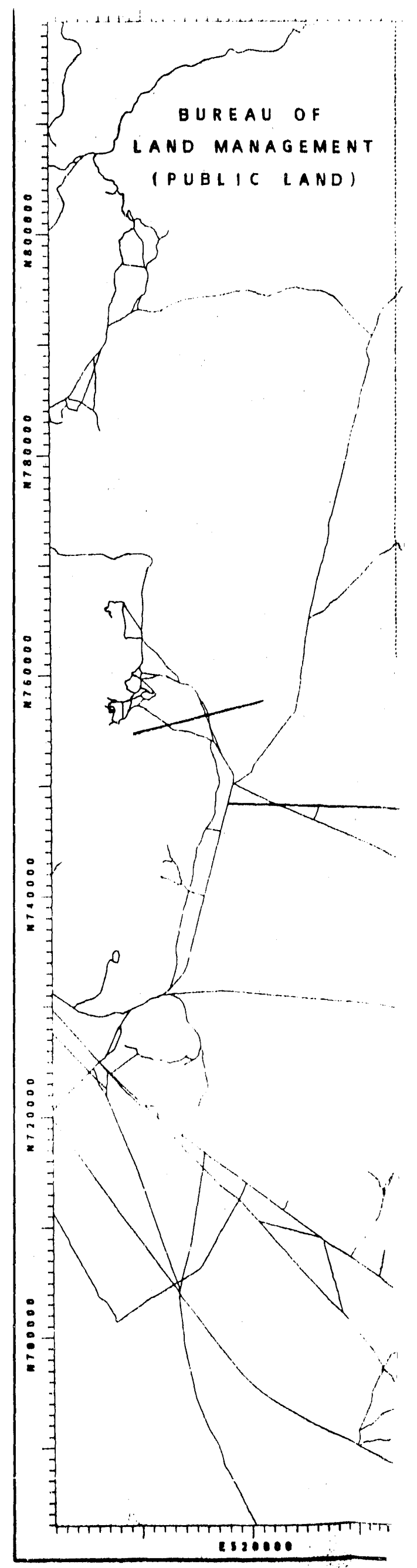




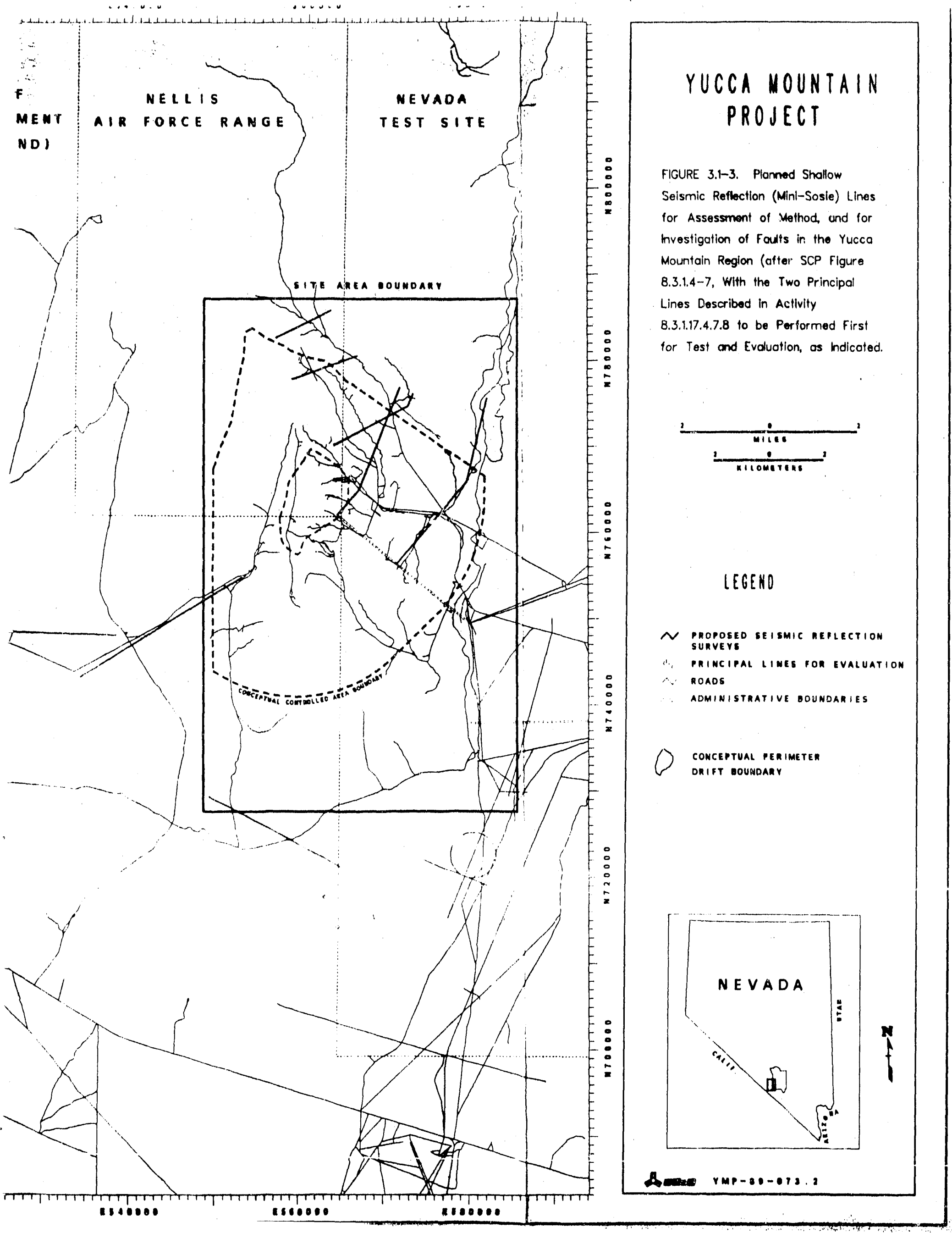




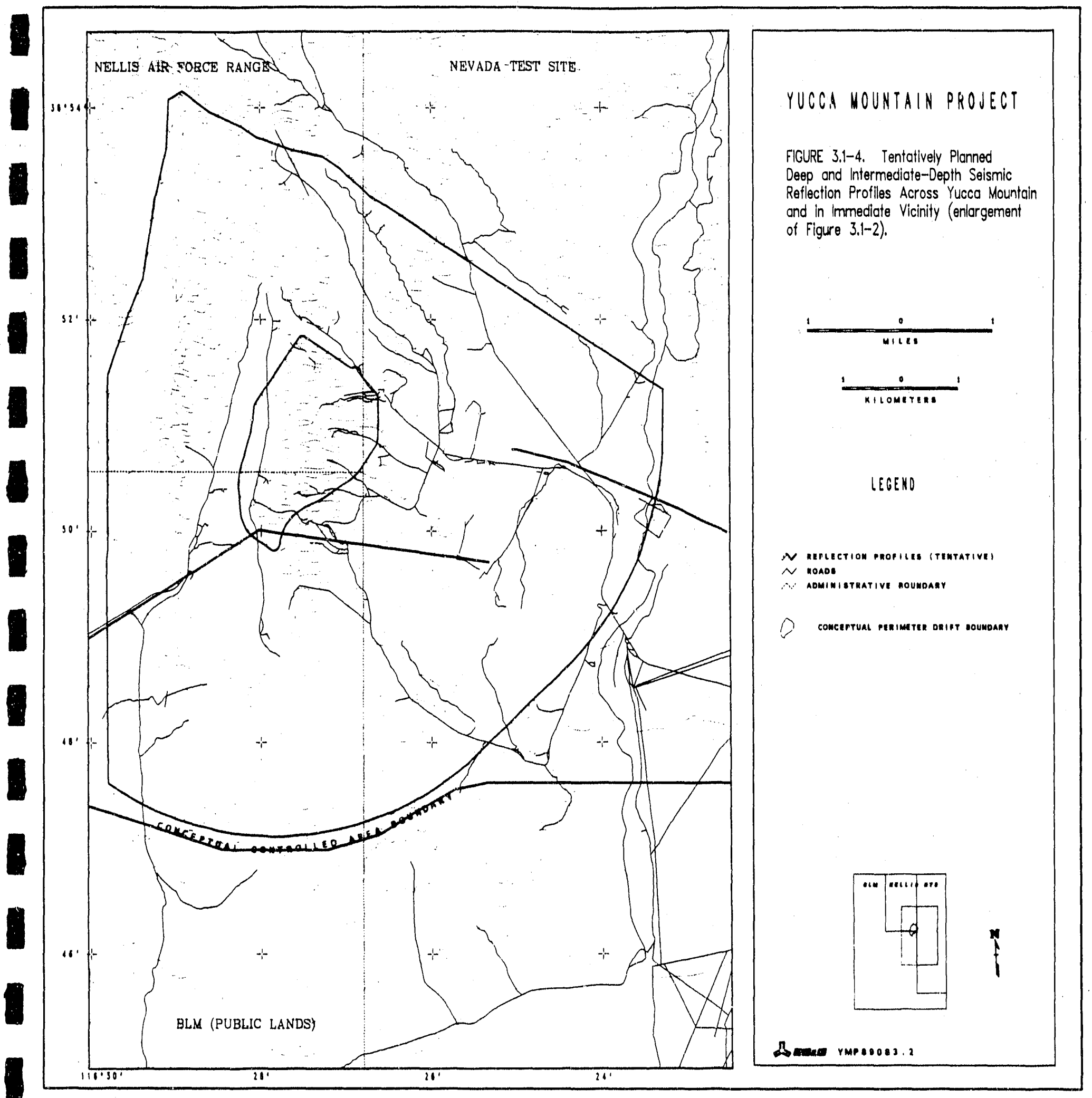


will also be examined in Activity 8.3.1.17.4.9.1 for indications of desert varnish that may be associated with tectonically stable areas.

Regional geophysical activities will involve the detailed study of a number of specific faults in the Yucca Mountain region. Some of these studies are ongoing, or are substantially complete as discussed below and in USGS (1988). The following paragraphs ciescribe plans for further study of several faults, in a manner that is similar to previous studies. Also, several feasibility tests are described that will determine the applicability of shallow seismic refraction and Mini-Sosie reflection methods for fault characterization.

An activity $(8.3 .1 .17 .4 .7 .8)$ is planned to further evaluate the application of the Mini-Sosie method of shallow reflection at and proximal to the site area. Past results are mixed for imaging of faults in alluvium because the faulting is typically complex, and the reflecting horizons are sparse and weak. Harding (in USGS, 1988) reports moderate success at Crater Flat and the Beatty scarp, but some uncertainty remains as to application of the method for characterizing amount of fault offset and other aspects. Accordingly, this activity calls for nine profiles within the site area and at other selected leatures, of which two are designated preliminary traverses (the Jackass Flats and Fran Ridge traverses of Figure 3.1-3) and will be performed before the others. A decision to proceed with all profiles, or to apply the method more selectively, will be based on preliminary results.

Subsurface expression of the Rock Valley fault will be mapped using shallow refraction and reflection (Activity 8.3.1.17.4.4.1). This activity is 908 complete (see USGS, 1988). Qu-ternary displacement along the main fault trace was investigated using low-energy seismic refraction. Refracting horizons reported by Rodriguez and Yount (in USGS, 1988) suggest that it is possible to detect fault offset and other characteristics from refraction continuity and moveout. Deeper faulting (up to several hundred meters) was examined using the Mini-Sosie method (Harding, in USGS, 1988). The southern extension of the Rock Valley fault system south of the Amargosa Valley fault will be investigated using the same methods. The objectives are to estimate fault width, detect Quaternary displacement, and detect horizontal and vertical components of slip. The same techniques used to evaluate the main trace will be used to evaluate whether the faulting events that have been identified involve the southern extension of the fault zone.

The Mine Mountain fault zone will be evaluated primarily by synthesis of available geologic information (Activity 8.3.1.17.4.4.2). The seismic reflection data of McArthur and Burkhard (1986) will be reviewed. Mini-Sosie shallow reflection data will be acquired depending on whether the method provides useful information on fault offset and configuration (Activity 8.3.1.17.4.7.8). In a similar study, the Cane spring fault system, proximal to the Mine Mountain and Rock Valley faults, will be investigated using shallow seismic refraction to evaluate the origin of known lineaments which may be associated with faulting of Quaternary deposits (Activity 8.3.1.17.4.4.4).

The Stagecoach Road fault south of the site will be investigated to estimate the nature and rate of faulting, and the relationship to the Paintbrush Canyon-Busted Butte fault zone (Activity 8.3.1.17.4.4.3). This 
fault may be important to estimates of ground motion at the site because of its proximity to the repository site, and because models suggest that rupture on this fault may occur concurrently with activity on other faults. Mini-Sosie data also will be acquired depending on a determination in Activity 8.3.1.17.4.7.8 that the method provides useful information on fault offset and configuration.

\section{Characterization of Volcanic Features}

Geophysics is an important part of planned studies of volcanic and intrusive igneous features and processes in the Yucca Mountain region. Aeromagnetic, seismic, and gravity data generated in other studies of the SCP (notably Studies 8.3.1.17.4.3 and 8.3.1.17.4.7) will be used to evaluate structural controls on basaltic volcanic activity (Study 8.3.1.8.1.1). Cluster analysis will be done on the location of surface and subsurface volcanic deposits, based partly on aeromagnetic data. The presence of magma bodies beneath the site will be evaluated using a range of geophysical methods, each of which is planned for a different study in the SCP. Such methods include high-resolution upper-crustal seismic refraction and deep seismic reflection (Activity 8.3.1.17.4.3.1), gravity (8.3.1.17.4.7.2), magnetics (8.3.1.17.4.7.3), magnetotellurics (8.3.1.17.4.3.1), Curie isotherm interpretation (8.3.1.8.5.2.1), and teleseismic tomography (8.3.1.8.1.1.3).

Four aeromagnetic anomalies already identified in Crater Flat and Amargosa Valley (Kane and Bracken, 1983) will be resurveyed at ground level or along flightlines $100 \mathrm{~m}$ above the surface and spaced $100 \mathrm{~m}$ apart. A detailed gravity survey will be acquired on a grid of about $30 \mathrm{~m}$ dimension (Study 8.3.1.8.5.1). These data, which will be collected under another study (see Activity 8.3.1.17.4.7.4), will be used to estimate volumes of buried volcanics and shallow intrusions, and to site boreholes. A feasibility test is planned (see Section 3.3 of this report) for evaluating the use of geophysics for detection and delineation of volcanic deposits. Paleomagnetic orientation from drill cores will be used to estimate the age of lava flows and shallow intrusions (see Activity 8.3.1.4.2.1.5). The Curie isotherm will be reinterpreted in more detail (see section 2.2 of this report) as new detailed aeromagnetic data become available, for investigation of the possibility of upwelling magma (see Activity 8.3.1.8.5.2.1). Reinterpretation of the Curie isotherm will inciude appropriate consideration of edge effects in the analysis method, as they may affect the quality of interpretation throughout the Yucca Mountain region.

Teleseismic

Teleseismic tomography is included as an analysis technique in SCP Activity 8.3.1.8.1.1.3 (Presence of magma bodies in the vicinity of the site). Data for tomographic analysis are collected under Activity 8.3.1.17.4.1.2 (monitor current seismicity). A related higher resolution technique called "NeHT" tomography (pronounced "net"; Evans and Zucca, 1988) is not included in current plans, but would be useful in several studies (see i.tem 4 below). Other activities in which these techniques may be useful include (1) Activity 8.3.1.8.2.1.3 (Probability and rate of faulting), (2) Investigation 8.3.1.17.1 (Studies to provide required information on volcanic activity that could affect repository design or performance), and (3) Study 8.3.1.17.4.5 (Detachment faults at or proximal to Yucca Mountain). The 
relation of teleseismic tomography to other types of surveys will be examined by the geophysics integration activity (SCP Section 8.3.1.4.1.2).

A number of structural hypotheses that are important to site characterization can be addressed by teleseismic tomography. The regional-scale study and the north fringe of the fine-scale study indicate that complex structures are present beneath the Timber Mountain-Oasis Valley caldera complex. These structures may include low-velocity lows such as those beneath Crater Flat. The low-velocity upper-mantle anomaly beneath the southern part of the NTS and the overlying crustal structure should be imaged at higher teleseismic resolution to investigate its tectonic significance.

Based on preliminary results discussed in Section 2.8 of this report, four restricted-array seismic tomography studies are under consideration:

1. Higher resolution $P$-wave teleseismic tomography studies of the southern NTS/Yucca Mountain region to image the upper-mantle velocity-low and its Moho-depth connections, if any, to the Crater Flat columnar velocity-low. (This study will clarify the nature of the basalt magma system, possibly identifying the size and location of the magma source and any major active intrusion paths.)

2. S-wave teleseismic tomography and $Q_{p}$ teleseismic tomography of the Crater Flat columnar velocity-low to permit better detection and definition of melting in the middle and lower crust. These parameters can be obtained from any array of intermediate-period seismometers. P-wave velocity alone is ambiguous in this regard because many things can cause small variations in that single parameter, Knowledge of both velocities and $\ell_{p}$ permits a better interpretation.

3. A higher resolution P-wave teleseismic tomography study of the Timber Mountain/Sicent Canyon area would provide detailed crustal and upper-mantle information, principally for comparison with Crater. Flat. Existing data suggest that a columnar velocity-low exists under the Timber Mountain caldera, which would imply that this is a common feature of inactive silicic calderas, and thus support an alternative interpretation of the crater Flat velocity-low.

4. An active-source high resolution "NeHT" tomography study of the Yucca Mountain site area can image the tuff/Paleozoic boundary with $500 \mathrm{~m}$ or better accuracy, resolving the location and crientation of the Crater Flat east-boundary structure. The same experiment can evaluate the occurrence of upper-crustal silicic magma chambers as small as $500 \mathrm{~m}$ across. This technique is applicable to study 8.3.1.17.4.7 (Subsurface geometry and concealed extensions of Quaternary faults at Yucca Mountain) and Activity 8.3.1.8.1.1.3 (Presence of magma bodies in the vicinity of the site).

Support of Paleoclimate Studies

A shallow ( $<1.0$ sec travel time) high-resolution seismic reflection method, based on the feasibility testing of various techniques (Activity 8.3.1.4.1.2), may be utilized in the Paleoclimate study (8.3.1.5.1.2) to 
analyze the stratigraphy-sedimentology of marsh, lacustrine, and playa deposits (Activity 8.3.1.5.1.2.2). This activity requires establishing the three-dimensional lithostratigraphic framework of various marsh-lacustrineplaya environments, which are characterized by sequences of fine-grained clastic deposits. Seismic reflection profiles will be used to define this framework, and to provide guidance for establishing the optinal locations for drilling sites. Seismic reflection properties of these fine-grained clastic sequences may be substantially different than the reflection properties of the highly fractured Miocene volidnic sequences comprising Yucca Mountain: consequently, different instrumentation may be required. Various reflection systems (e.g., Mini-Sosie, sledgehammer shear wave source, vibrator source, land air-gun) will be considered for possible application, in an effort to obtain optimum results.

\subsubsection{GEOPHYSICAL STUDIES IN THE SITE AREA, FOR GEOLOGY AND TECTONICS}

\section{STRUCTURE AND STRATIGRAPHY}

The work described jointly by SCP Studies 8.3.1.4.2.1, 8.3.1.4.2.2, and 8.3.1.17.4.7 will involve extensive collection of geophysical information from the site area in support of the site tectonic model. Data on the distribution of mass, geoelectric features, seismic velocity structure, magnetization, and seismic reflectors will be used to detect and delineate features with possible tectonic significance. Data also are needed to map known Quaternary faults where concealed by surficial deposits, to evaluate whether Quaternary faults exposed as high-angle faults continue as such to depth or flatten and merge with one or more low-angle faults, and to evaluate the continuity of rock units within the repository block and controlled area.

Surface geophysics will also be used to increase confidence in stratigraphic models of Yucca Mountain. Detailed gravity, ground magnetics, EM soundings, high-resolution seismic reflection, and upper-crustal high-resolution seismic refraction wil? be used, as appropriate, to establish and interpret sites for drillholes (Activity 8.3.1.4.2.1.1). Much of the planned geophysical work that is applicable to site stratigraphy and the geologic model is described for study 8.3.1.17.4.7. The following is a discussion of planned activities that will provide information on the geologic setting, and the nature of faulting in the site area.

\section{Detailed Gravity}

Detailed gravity data will be collected to supplement the currently available gravity maps for the site area, which are constructed from observations too widely spaced for discrimination of faults or detection of discontinuous rock units (Activity 8.3.1.17.4.7.2). A 1:24,000-scale map will be developed from new data collected at $60-\mathrm{m}$ spacing along east-west lines spaced $150 \mathrm{~m}$ to $300 \mathrm{~m}$ apart, topography permitting (Figure 3.1-5). A total of approximately 7,500 additional gravity stations are planned for this effort. Additional high-resolution gravity work is planned for assessing buried volcanics at selected locations in the Amargosa Desert (Study 8.3.1.8.5), and for investigating the large hydraulic gradient northwest of the site as discussed in section 3.1 .2 of this report. 
The following paragraphs discuss the capability of detailed gravity to detect faults in the site area. Because density generally increases with depth (Snyder and Carr, 1982), terrain-corrected gravity is generally lower on the downthrown side, and higher on the upthrown side of a fault with vertical offset. To examine the relative magnitude of this effect, a two-dimensional profile across the site area was postulated, using density data from borehole gravity and gamma-gamma density log surveys. Basic features of the model were taken from surface geologic mapping. A density of $2.8 \mathrm{gm} / \mathrm{cc}$ was used below the Paleozoic basement.

Hypothetical faults with offsets of $40,80,160$ and $500 \mathrm{~m}$ cause gravity anomalies with amplitudes of $0.2,0.4,0.9$, and $3 \mathrm{mgal}$, respectively, and spatial extent about $500 \mathrm{~m}$. Hence, station spacing should be about $100 \mathrm{~m}$ perpendicular to the expected strike and the gravitational effect of faulting may be masked by terrain effects, which are difficult to correct because of non-uniform terrain density.

Where terrain effect is minimal, fault interpretation depends on data uncertainty from other sources including gravity measurement, station location, and reduction parameters. Measurement errors of less than $0.3 \mathrm{mgal}$ can be achieved if high precision measurement techniques and drift correction methods are followed. Location errors affect vertical control producing gravity uncertainty of $0.2 \mathrm{mgal}$ per meter of elevation. Elevation can be controlled to $0.10 \mathrm{~m}$ using an electronic distance measuring device, limiting the error to about $0.02 \mathrm{mgal}$.

Much of the uncertainty in the reduction procedure is caused by the terrain correction, which is generally assumed to be accurate to within $5 \%$ of its total value. Typically, terrain corrections at the site area are as large as $2 \mathrm{mgal}$, with $0.10 \mathrm{mgal}$ uncertainty. However, with the expected availability of a gridded $(30 \mathrm{~m})$ digital elevation model, terrain corrections should be more accurate, perhaps to $0.02 \mathrm{mgal}$. The sum of errors from measurement, elevation control, and corrections gives a total expected uncertainty of less than $0.07 \mathrm{mgal}$. Thus the detailed gravity method should detect steeply dipping faults with vertical offset on the order of $40 \mathrm{~m}$ in gentle terrain, provided that the terrain effect is minimal, adequate station spacing is maintained, and profiles are oriented perpendicular to strike.

Borehole gravimetry can be used to obtain bulk density, and detect contacts between different media in the immediate vicinity of the borehole. In principle, borehole gravity measurements are sensitive to density differences in a region extending in every direction for about three times the spacing between measurements in the borehole (for typical station spacings). Thus the method might be used to infer contacts between different stratigraphic units such as highly lithophysal and nonlithophysal tufis over a large area of the repository block, given sufficient density contrast and sufficiently accurate terrain corrections. This possibility will be investigated using presentiy available data from four boreholes at Yucca Mountain (Healey, 1984, 1986) and terrain corrections calculated with high-resolution digital topographic. Borehole gravity will also provide bulk density information for terrain corrections of surface gravity stations. The existing borehole gravity data, and possibly data collected in the future from other boreholes, will be used for this purpose. 


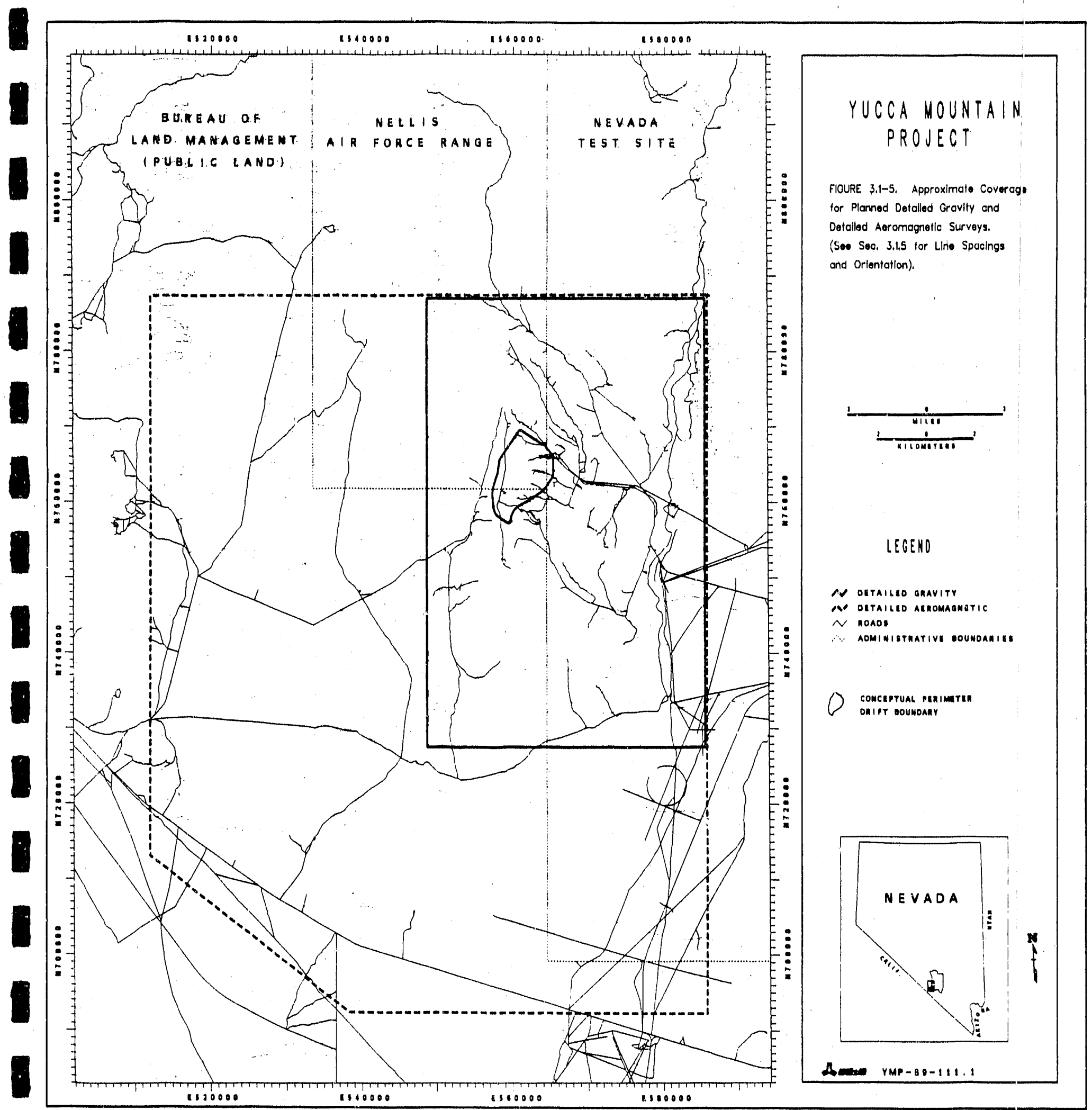


Aeromagnetic and Ground Magnetic Surveys

Aeromagnetic maps of the site that are currently available are based on flightlines spaced $1 / 4$ mile apart (see section 2.2), too widely spaced to resolve ambiguities in fault continuity or to demonstrate continuity of rock units in the site area. A 1:12,000-scale map will be developed from data to be collected along flightlines spaced 1/16 mile apart, and draped over the topography at $400 \mathrm{ft}$ (Activity 8.3.1.17.4.7.3). The area to be covered by this survey will be comparable to previous surveys of the site area discussed in Section 2.2; the actual area will be determined by the Principal

Investigator with input from the geophysics integration activity, and will reflect data needed for various applications including assessment of volcanic hazards and mineral resources.

Ground magnetic surveys of specific features within the site area are planned to measure variation in magnetization of specific strata and surface deposits (Activity 8.3.1.17.4.7.4). Ground magnetic data will be collected on foot, at 3- to $60 \mathrm{~m}$ intervals, to characterize the location and continuity of rock units, and to invesigate known and inferred structures in the vicinity of certain faults, shafts, surface facilities, drillholes, and aeromagnetic anomalies. A recording base-station magnetometer will be used during the surveys as appropriate. Not all such features will be surveyed; the number and location will be determined by the Principal Investigator with input from the geophysics integration activity. Ground magnetic data also will be collected along geophysical traverses incliding the detailed gravity lines (Figure 3.1-5), and other profiles intended 0 detect concealed faults in the site area or to investigate the steep hydrologic gradient beneath northern Yucca Mountain.

As an independent test of the feasibility of using magnetics to detect concealed faults, it is proposed that truck magnetometer profiles be collected along roads and in some off-road areas of southern Yucca Mountain. The off-road profiles would be collected along closely spaced $(30 \mathrm{~m})$ parallel traverses perpendicular to fault trends. Positioning could be accomplished using range-range radio navigation. Magnetic gradients traced across known and inferred fault traces would provide information for evaluation of the magnetic method for characterizing buried faults and contacts.

Ground magnetic traverses will provide estimates of the resolution of ground magnetic data to detect buried faults and lithologic contacts in the Yucca Mountain area. Simple upward continuation of these profiles will be used to evaluate the trade-off between increased signal-to-noise ratio and decreased short-wavelength resolution in aeromagnetic data, as a function of terrain clearance.

Detailed ground magnetic and gravity surveys will be performed near USW $G-5, G-6$, and G-7, associated with these planned 1,500-m cored boreholes. Information on magnetic and density variation will be used to map the local vertical and lateral distribution of stratigraphic units in order to augment the structural and stratigraphic information obtained from the cored boreholes. 
The results of electrical surveys previously carried out at Yucca Mountain (Section 2.3 and Table 2.3-1) must be evaluated before planning future surveys, as stipulated in Activity 8.3.1.17.4.7.5. Surveys over Yucca Mountain must be designed to detect lateral electrical boundaries associated with faults and lithological variations in a bedrock environment which is generally resistive (greater than 300 ohm-meters) at the si face and becomes more conductive with increasing depth. Survey design and $i$, erpretation must contend wi.th rugged topography and near-surface variability in the weathered zone, both of which produce changes of first order in the electrical data. In order to account for such three-dimensional effects, the project requires complementary overlapping date sets that use the capabilities of different methods to achieve maximum depth of penetration with minimum distortion by lateral effects. The interpretation methods and software available for each electrical method play a major role in the ultimate accuracy and resolution of the final interpretation, and hence are factors in survey design.

Recent advances in field and interpretative time-domain technology make the time-domain method a primary candidate for deep sounding (greater than $1,000 \mathrm{~m})$ and profiling, supplemented by a loop-loop frequency-domain electromagnetic method for shallower (less than $200 \mathrm{~m}$ ) depths. The audio-magnetotelluric method, supplemented by teliuric ratio measurements, is also important for deep sounding and profiling because the data are highly amenable to the interpretation of three-dimensional structures. Several east-west lines over Yucca Mountain utilizing combinations of these techniques will provide insight on structures related to the Yucca Mountain block.

The same techniques are also useful for fault detection in the alluvial valleys nearby. They would be supplemented by schlumberger soundings to provide a high resolution definition of the conductive overburden that must be accounted for in interpreting deeper structure.

As previously discussed in section 3.1.4 of this report, magnetotelluric soundings with their unique capability to penetrate to depths exceeding $3 \mathrm{~km}$ are the most desirable technique to examine the regional geoelectric structure. These regional data will provide important lithologic and structural constraints that will serve in the tectonic evaluation of the Yucca Mountain block.

\section{Radioactivity and Remote sensing}

Airborne and ground-based gamma-ray surveys will be evaluated for use in detecting buried faults in the site area (Activity 8.3.1.17.4.7.6). Buried faults must be detected by near-surface distribution of radioelements, possibly caused by percolation of meteoric waters or migration of radon or dissolved elements in a fault zone. Available airborne radioactivity data from the NTS (both classified and unclassified) will be evaluated. Hand-held gamma-spectrometers will be tested along short $(100 \mathrm{~m})$ traverses across the Paintbrush Caryon, Bow Ridge, and Stagecoach Road faults. This is planned as a feasibility test; application of the method to site characterization will depend on the results. An airborne gamma-ray survey, if warranted, will be 
performed simultaneously with the planned aeromagnetic survey (Activity 8.3.1.17.4.7.3).

Seismic Reflection

Intermediate-depth reslection and refraction methods will be evaluated for application to site characterization, and possible applications of these methods will be planned in Activity 8.3.1.17.4.7.1. This is a planning activity only, which will review previous attempts and currently available technology, and assess the potential contribution of seismic methods to characterization of faults in the site area. This review will be separate from the review of the planned regional geophysical traverses (Activity 8.3.1.17.4.3.1), but both deep- and intermediate-depth objectives for seismic lines in the site area and vicinity (Jackass Flats, Crater Flat, northern Amargosa Valley) will de considered. Results from the Amargosa Valley seismic reflection test (Brocher et al., 1989) are applicable, possibly in different ways, to both reviews.

Tentative plans presently call for two deep-seismic lines across Yucca Mountain, to be conducted in a manner similar to the Amargosa Valley reflection test (Brocher et al., 1989). These lines will intersect with a north-south reflection line in Crater Flat and other north-south geophysical profiles (refraction and MT) to the east and west of the site area (Figures $3.1-2,-3$, and -4). Abundant information on the intermediate-depth structure was obtained from the Amargosa Valley test, but the structural setting of the upper 2-3 km at Yucca Mountain is relatively complex, and the same methods may not apply as well. This aspect of the planned lines across Yucca Mountain will be evaluated in the peer review planned for Activity 8.3.1.17.4.7.1, as will the objectives for deep- and intermediate-depth exploration within the site area and vicinity, the applicability of three-dimensional seismic methods, intersecting geophysical lines in the site area, and the applicability of VSP.

The report of previous attempts at intermediate-depth seismic reflection at Yucca Mountain (McGovern, 1983) recommends avoiding further application of reflection methods. The report identifies deficiencies in the 1980 and 1981 surveys that were addressed in the 1982 survey, which is represented as a thorough but unsuccessful application of available technology. However, Jones et al. (1987) believe that other techniques are now available and should be tried at Yucca Mountain. Possible improvements to the 1982 survey include (1) scoping studies using downhole recordings in available boreholes; (2) location of lines in simple structural settings, oriented perpendicular to structure; (3) use of the stack array concept (Jones et al., 1987) for noise suppression; and (4) geophone placement st.rategies including single phones and/or closely spaced groups to support statics analysis.

VSP surveys can and should be used with existing boreholes, prior to large-scale reflection surveys, to characterize intrinsic and apparent attenuation, mode conversion and splitting, reverberation, and the nature of reflections expected from the upper $2-3 \mathrm{~km}$ at the site. Different sources, source offsets, and surface receiver spreads are also used in conjunction with VSP geometry to evaluate acquisition parameters for surface seismic reflection. 
Previous reflection lines at the site were situated proximal to ridges, canyons, and known faults, and may not have had sufficient noise rejection capability to handle side-scattered energy. As pointed out by Brocher et al. (1989), an important difference between Vibroseis and impulsive sources is that the Vibroseis source is still active when the surface wave noise train reaches the geophones, because the Vibroseis source records are uncorrelated in time. Some potentially significant improvements in noise control between the Amargosa Valley test line (Brocher et al., 1989) and the 1982 survey at Yucca Mountain (McGovern, 1983) relate to wind monitoring and onsite processing capability.

It is apparent from the preceding comments that significant improvements may be possible, particularly with the use of VSP to reveal some of the mechanisms that affect reflection data from the site. As stated above, this topic will be considered as part of Activity 8.3.1.17.4.7.1 and the geophysics integration activity.

The high-resolution Mini-Sosie reflection method (see Section 2.5) may be applied to characterization of structures in the site area, if appropriate, based on evaluation of the technique in Activity 8.3.1.17.4.7.8. A number of shallow seismic reflection profiles will be used to study the position of possible marker horizons, at the site. The planned lines (see Section 3.1.4, and Figure 3.1-3) will be used to trace the subsurface extent of known structures (e.g., faults) where they are concealed by surface deposits, and to investigate the lateral continuity and structural features of reflecting horizons. Other high-resolution refraction or reflection methods may be tested, depending on resulss obtained from further Mini-sosie work.

\section{Seismic Refraction}

An east-west refraction profile will be acquired across the Prow (Scott and Bonk, 1984) and Yucca Wash to explore for a lateral velocity contrast, possibly associated with changes in lithology caused by structural displacement or alteration processes, that could help to explain the large hydraulic gradient north of the site (Activity 8.3.1.4.2.1.2). This line will be located in the vicinity of planned geologic coreholes USW G-5 and G-6. Plans for this refraction line will be reviewed in the planned peer review of seismic methods (SCP Activity 8.3.1.17.4.7.1; see section 3.2 of this report). The tentative location of this line is plotted on SCP Figure 8.3.1.4-6.

As stated above, an assessment of stratigraphic information needed from the site area will be considered along with tectonics in the planned review of the applicability of seismic reflection and refraction to intermediatedepth (<2 or $3 \mathrm{~km}$ ) structural profiling (Activity 8.3.1.17.4.7.1). Past experience (described in Section 2.4) shows that the high-resolution upper-crustal refraction method as described by Ackermann et al. (in USGS, 1988) can produce interpretable, but relatively low resolution structural information. On the other hand, the lower energy, higher resolution surveys reported by Pankratz (1982) yielded signals of relatively low quality, which were difficult to reconcile with stratigraphic and velocity data from nearby boreholes. The underlying basis for these observations is undoubtedly complex, and will be taken up in the planned review. 
Information on the frequency and subsurface distribution of faults and fractures is needed principally from the UZ, because the DOE plans to rely on natural barriers between the repository and the waler table to demonstrate site performance. Accordingly, many of the methods used to detect and characterize subsurface fractures in the $S z$ are of secondary importance or are inapplicable. The limited range of methods which do not require water-filled boreholes, or water-filled fractures, will be thoroughly investigated during site characterization. Also, because of the unique aspects of fracture characterization in the UZ, a multidisciplinary approach is planned to compare different methods at the same location. At the USW UZ-9 complex of boreholes east-southeast of the site, and in the ESF, geophysical data will be acquired from regions of the rock mass for which fracture data are available from other techniques, including borehole packer testing and shaft wall mapping.

\section{Borehole Geophysics}

Borehole television is known to produce useful information on fracturing in the UZ; it is part of the standard suite of logs planned at Yucca Mountain. The borehole acoustic televiewer, resistivity, SP, and full-waveform acoustic logs will be used in the $\Omega z$, as discussed in the literaturo (for example, Paillet, 1980) and in Section 3.1.2. However, fracture data from the Sz are not generally applicable to the unsaturated portion of the repository block because of differences in lithology, structural context, and in situ stress distribution. Morever, future boreholes at Yucca Mountain will be largely restricted to the UZ as a target for exploration (in terms of numbers of holes, and spatial coverage). Thus the opportunities for use of more conventional SZ geophysical tools and extension of this database to the Uz will be limited.

Large-spacing EM and resistivity logs will be tested and evaluated for application to fractured and lithophysal zones, and possibly for characterizing anomalies detected by other surface and borehole geophysical methods. Application of these methods to site characterization, particularly for UZ characterization, will depend on the outcome of feasibility testing.

Borehole-to-surface resistivity and EM methods will be used depending on results from surface and borehole surveys. The borehole-to-surface resistivity technique has been applied at Yucca Mountain (Daniels and Scott, 1981), as discussed in section 2.3, with results that are difficult to interpret geologically. Borehole-to-surface EM studies are discussed below.

\section{EM Tomography}

Current plans are to focus on application of existing technology that is suitable for characterization of faulting, fracture distribution, and trends in moisture content in the UZ at Yucca Mountain (Activity 8.3.1.4.2.2.3). Various borehole radar tools are available for use by the Project (e.g., from the USGS and Sandia National Laboratories). In addition, borehole radar tools have been developed for repository site characterization by the Swedish and German repository programs and could probably be made available for 
evaluation at Yucca Mountain. However, borehole radar is not expected to perform in the UZ at Yucca Mountain as it performs in crystalline rock or salt, because of the proliferation of moisture. Fractures and fault zones probably do not behave as radar reflectors, although major stratigraphic contacts may behave as such. Limited scoping analyses and field trials will be considered during site characterization to evaluate borehole radar and related radar methods.

The operating frequency of available borehole radars varies between about 20 and $80 \mathrm{MHz}$. Depending on the in situ resistivity, which can vary from 20 to 2,000 ohm-meters in the Uz, two-way radar penetration varies from roughly 10 to $100 \mathrm{~m}$ (D. Wright, personal communication). This type of performance is consistent with hole-to-hole penetration for imaging purposes at either the "c-series" boreholes or the planned USW UZ-9 complex.

VHF tomography is similar to crosshole radar, generally differing with respect to detection method and frequency. Ramirez and Daily (1987) reported a series of measurements made in welded tuff at the G-tunnel, using crosshole equipment operating at $200 \mathrm{MHz}$ to image the rock mass both before and after a heater test was conducted. The length of the travel paths in this experiment ranged up to several meters. Results indicate that detectable changes in dielectric permittivity are associated with processes that are important for site characterization. The method is planned for use in the waste package (heater) test series in the ESF, and could possibly be used for mapping the extent of water injection from various hydrology tests, such as the planned Radial Boreholes Test in the ES-1 shaft. VHF tomography as used in G-tunnel produces images with signal strength and spatial resolution better than what can be expected from tools operating at lower frequency in widely spaced surface-based boreholes." The method might be used in the closely spaced, planned USW UZ-9 complex of boreholes; however, this application would not produce alterant data as acquired in G-tunnel and planned for the ESF. Water injection testing in the Uz boreholes is only tentatively planned and will not be conducted until late in site characterization.

If crosshole VHF tomography results show that rock mass features detected in boreholes can be mapped between boreholes, and that penetration is useful, then the method may be extended to a borehole-to-surface configuration. With three-side access and raypath coverage of the plane intersecting parallel boreholes, the stability and resolution of tomographic algorithms are improved. Borehole EM or borehole-to-surface EM methods are also available and will be evaluated, as appropriate.

\section{Vertical Seismic Profiling (VSP)}

Planned VSP studies in the UZ at Yucca Mountain are discussed in detail. in section 3.1.1 above. Two studies are planned, one at the ESF and the other at the planned USW UZ-9 complex of boreholes. Each of these studies will use three-component sensors and a range of available sources will be considered, including vertical and shear vibrators, land air-gun, shear-impact sources, and explosives. Interpretation of VSP in boreholes (e.g., Activity 8.3.1.2.2.3.2) will be augmented by performing similar surveys in shafts and underground workings where more direct observations of fracturing and other rock mass characteristics can be obtained (Activity $8.3 .1 .4 .2 .2 .5)$. 
If successful, the VSP approach to fracture and fault characterization in the repository block may provide a means of mapping the nature and distribution of fractures in the subsurface. Also, the method could be applied to performance confirmation, both in the sense of acquiring baseline data on the mechanical condition of the repository block, and for monitoring changes as a result of repository construction and operation.

3-D CHARACTERIZATION OF LITHOLOGY AND HYDROLOGIC STATE OF THE REPOSITORY BLOCK

\section{Borehole Geophysics}

A standard suite of geophysical logs will be acquired from every deep borehole that penetrates the Topopah Spring Member in the site area (Activities 8.3.1.4.3.1.1, 8.3.1.4.2.1.3, and 8.3.1.2.2.3.2). In addition, logs are already available from 40 existing boreholes. Depending on the development of methods for correcting and interpreting various log responses from the unsaturated tuffs (as discussed in Section 2.7), these logs could become the most continuous record of lithologic and hydrologic variability available, with better spatial coverage of the repository block (vertical and lateral) than other types of data.

Commercial logs to be obtained as a standard suite from future boreholes in the UZ at Yucca Mountain include compensated density, induction, spectral gamma, epithermal neutron (single shielded detector), dielectric log (47 $\mathrm{MHz}$ ), temperature, and caliper. In the SZ, the standard suite will include resistivity, SP, induced polarization, full waveform sonic, and the compensated neutron porosity log. The total magnetic intensity log, and possibly the magnetic susceptibility log, are indicative of certain horizons in the tuff sequence at Yucca Mountain and will become part of the standard suite of logs, although they may not be available commercially. It is anticipated that this full suite will adequately support lithologic interpretation and correlation.

The compensated density log will be used to characterize lithophysal zones where only cuttings are available, or where poor resolution exists on borehole television. Preliminary analysis shows that spikes prevalent on compensated density logs from Yucca Mountain are generally associated with borehole rugosity and not lithophysal porosity. The compensation algorithm for dry holes in volcanic tuff is presently being evaluated.

The induction and spectral gamma logs are expected to serve as indicators of smectite- and zeolite-rich intervals, and to identify key stratigraphic marker intervals at the top and base of major ash flows, which commonly show increased alteration. Preliminary indications are that the induction $\log$ can be used only qualitatively in much of the $U z$, because the formation resistivity is so high that the signal is small and accurate resistivity values cannot be obtained.

The dielectric log, discussed in section 3.1 .1 of this report, will also be evaluated for detecting trends in hydrologic characteristics such as moisture content. Propagation of EM energy in the UZ at Yucca Mountain is 
dependent on pore geometry, saturation, and mineral alteration (which may also be related to moisture content).

The second objective of logging for three-dimensional characterization is to determine the distribution of rock characteristics (physical properties) within lithostratigraphic units in each borehole and then to map their distribution throughout the site. The physical property logs are essentially "computed logs" of such parameters as bulk density, porosity, water content, and alteration chemistry. The ability to compute these parameters depends on initial log quality, availability of core data, and development of algorithms to convert log quantities to the desired physical properties. These activities are part of the petrophysics and log analysis program planned for site characterization (SCP Studies 8.3.1.4.2.1 and 8.3.1.2.2.3). (Once the computed logs are available in a borehole, the physical properties must be averaged over vertical intervals which are consistent with lithological and hydrological zonation. Only then can these important parameters be mapped over the site area.) The application of geostatistical methods to modeling of the spatial variability of these log products will be investigated when the calculated logs become available.

\subsubsection{ENGINEERING GEOPHYSICS FOR SURFACE FACILITIES SITING}

Various locations in Midway Valley, in the vicinity of Exile Hill, have been identified as possible sites for the repository surface facilities, particularly for the structure containing the waste handling and packaging system (see Chapter 6 of the SCP). As indicated in the issue resolution strategy for SCP section 8.3.1.17, principal concerns for surface facilities siting, which will be addressed by geophysical exploration, are (1) avoiding fault displacement of more than a few inches under the waste handling structure; and (2) meeting probabilistic limits for peak ground motion, time histories, and response spectra. The associated primary performance goals are therefore to locate a site where the probability of total net fault displacement for the preclosure time period is less than 1 in 100, and where descriptors of predicted ground motion meet certain goals.

Investigations in Midway Valley are important for obtaining the following information: (1) detection and characterization of faults including those buried by alluvium, (2) assessment of the seismic potential of fauits at or near the surface facilities sites, and (3) characterization of the dynamic properties of surficial deposits. Geophysical data are needed, although not required, for detecting and delineating fault offsets in the alluvium-bedrock contact and stratigraphic horizons within the alluvium. Such information can reveal where major faults emerge from the bedrock, and provide input for calculating the potential for slip associated with the surface expression of these faults. Shallow geophysical surveys can be used in conjunction with trenching across Midway valley (Study 8.3.1.17.4.2) to trace the lateral extent of fault offsets that may be observed in the trench walls. Seismic studies will provide information on velocities; however, in situ measurements using borehole, crosshole, and surface-to-borehole methods are also needed where appropriate to investigate the detailed structure of velocity and other properties affecting the response of the waste-handling structure to ground motion. 
Low-energy seismic reflection and refraction studies have been performed in the vicinity of Exile Hill (see Section 2.5) and along an east-west refraction profile across the central part of Midway Valley (Section 2.4). Interpretations based on these surveys (Reynolds, 1985; Pankratz, 1982) tend to be poorly constrained and are difficult to reconcile with data from nearby boreholes (RF-series boreholes near Exile Hill, and the UE25a\#l borehole near the line traversing Midway Valley). Other seismic methods are available that may be more effective for detecting and delineating faults, such as the use of shot holes and/or explosives for shallow work (A. Flint, personal communication) or the use of shear wave sources (see section 2.4). However, current plans call for evaluation of ground penetrating radar (GPR) before proseeding with further geophysics for fault offset detection at the Midway Valley surface facilities candidate site area. Studies in Yucca Flat labout $50 \mathrm{~km}$ northeast of Yucca Mountain) have shown that GPR is sensitive to faulting in the upper few meters of alluvium ( $I$. Shephard, personal communication), and may be observed down to a depth of $10 \mathrm{~m}$ or more.

One possible outcome of the planned work is that there exists a marker bed, such as the Bishop Ash bed of Izett et al. (1970) that is accessible to trenching, is not offset by faulting, and is of sufficient age to render the probability of faulting in $100 \mathrm{yr}$ insignificant (100 yr is the approximate duration of the operational period for the repository surface facilities in the current conceptual design; see SNL, 1987). Alternatively, it may be possible to reach the same conclusion using soils dating methods without relying on a marker bed. Thus it is at least conceivable that enough information could be collected to establish that the site meets the goals discussed above for faulting and ground motion, without mapping the geometry of the alluvium-bedrock contact. Additional seismic exploration in Midway Valley may be necessary depending on the results from GPR and trenching studies (Study 8.3.1.17.4.2).

\section{EXPLORATION OF THE ALLUVIUM-BEDROCK CONTACT}

The SCP (Studies 8.3.1.17.4.2 and 8.3.1.14.2.3) includes plans to map the alluvium-bedrock contact, if it should be required. Two candidate areas for exploration are the surface faulting area in Midway Valley and the proposed ESF location by Coyote Wash. Seismic refraction would be used for near-surface targets, electrical resistivity would be used for target horizons up to a few hundred meters, and Mini-Sosie or another reflection method would be used for deeper targets. Shallow refraction with a sledgehammer source was reported by Rodriguez and Yount (in USGS, 1988) to penetrate up to about $18 \mathrm{~m}$ in alluvium. Prototype shallow refraction testing in alluvium-filled washes in the site area produced similar results (see Section 2.4). One of the common electrical resistivity methods could be used for deeper features up to roughly $100 \mathrm{~m}$. The Mini-sosie method may produce interpretable reflections from the alluvium-tuff bedrock contact, where it is deep enough for this method (about $100 \mathrm{~m}$ or more) although (as discussed in Section 2.5) such contacts have not been found to produce strong reflections at Yucca Flat (N. Burkhardt, personal communcation). The reflection results 
reported by Reynolds (1985) for the Exile Hill area are not indicative of possible future results for the reasons discussed in Section 2.5.

\section{IN SITU ENGINEERING PROPERTIES}

There are two basic objectives for characterizing the in situ dynamic properties of soil and rock: (1) direct measurement of compressional and shear wave velocities (and attenuation if possible) to obtain in situ dynamic moduli and Poisson ratio; and (2) correlation of stratigraphic continuity between borings, as a basis for modeling the variability of dynamic properties. Crosshole methods using weight-drop methods, and borehole logging using standard tools for lithologic and physical properties evaluation, will be considered in study 8.3.1.14.2.3 when specific needs are developed. Because the existing and planned exploratory holes in the Exile Hill vicinity do not penetrate the water table, the use of many of the standard logging tools depends on maintaining a fluid column during logging. The use of such methods will be evaluated with respect to fluid losses during drilling, expected losses during logging, and the sensitivity of site performance to fluid invasion at the candidate locations for repository surface facilities. Methods of geophysical logging in "dry" holes, such as those planned for Activity 8.3.1.4.2.1.3, will also be considered.

\section{REFERENCES}

Barbier, M.G., 1983. The Mini-Sosie Method, International Human Resources Development Corp., Boston, Massachusetts.

Bath, G.D., and C.D. Jahren, 1984. Interpretations of Magnetic Anomalies at a Potential Repository Site Located in the Yucca Mountain Area, Nevada Test Site, U.S. Geological Survey Open File Report 84-120, 40 p.

Beydoun, W.B., C.H. Cheng, and M.N. Toksoz, 1985. "Detection of Open Fractures with Vertical Seismic Profiling," JGR, vol. 90, p. 4,557-4,566.

Brocher, T.M., P.E. Hart, and S.F. Carle, 1989. Feasibility Study of the Seismic Reflection Method in Amargosa Desert, Nye County, Nevada, U.S. Geological Survey Open File Report 89-133 (in press).

Cox, D.P., and D.A. Singer (eds), 1986. Mineral Deposit Models, U.S. Geological Survey Bulletin 1693, p. 379.

Craig, R.W., and J.H. Robison, 1984. Geohydrology of Rocks Penetrated by Test Well UE-25p \#1, Yucca Mountain Area, Nye County, Nevada, U.S. Geological Survey Water Resources Investigations Report 84-4248, 57 p.

Craig, R.W., and K.A. Johnson, 1984. Geohydrologic Data for Test Well UE25 p\#1, Yucca Mountain Area, Nye County, Nevada, U.S. Geological Survey Open File Report 84-450, 63 p. 
Czarnecki, J.B., and R.K. Waddell, 1984. Finite-Element Simulation of Ground-Water Flow in the Vicinity of Yucca Mountain, Nevada-California, U.S. Geological Survey Water Resources Investigation Report 84-4349, 38 p.

Czarnecki, J.B., and W.J. Oatfield, 1987. "Use of Drillers' Logs and Geophysical Surveys to Define the Hydrogeologic Framework of the Amargosa Desert, Southern Nevada" (abs.), Transactions, American Geophysical Union, EOS, vol. 68, no. 16, p. 302 .

deVoogd, B., et al., 1986. "Death Valley Bright Spot: A Midcrustal Magma Body in the Southern Great Basin, California?," Geology, vol. 14, p. 64-67.

Evars, J.R., and J.J. Zucca, 1988. "Active High-Resolution Seismic Tomography of Compressional Wave Velocity and Attenuation Structure at Medicine Lake Volcano, Northern California Cascade Range," Journal Geophys. Res., vol. 93, p. 15,016-15,036.

Fitterman, D.V., 1982. Magnetometric Resistivity Survey Near Fortymile Wash, Nevada Test Site, Nevada, U.S. Geological Survey Open File Report 82-401, $28 \mathrm{p}$.

Frischknecht, F.C., and P.V. Raab, 1984. "Time-Domain Electromagnetic Soundings at the Nevada Test Site, Nevada," Geophysics, vol. 49, no. 7, p. 981-992.

Greenhaus, M.R., and C.J. Zablocki, 1982. A Schlumberger Resistivity Survey of the Amargosa Desert, Southern Nevada, U.S. Geological Survey Open File Report 82-897, 151 p.

Hasbrouck, W.P., 1987. "Hammer-Impact, Shear-Wave Studies," in S.H. Dantron and S.N. Domenico (eds.), Shear Wave Exploration, Geophysical Development Series, vol. 2, Society of Exploration Geophysicists, p. 97-121.

Hasbrouck, W.P., 1988. "Five Shallow Seismic Feasibility Surveys," Expanded Abstracts, Society of Exploration Geophysicists, 58th Annual Intl. Meeting and Exposition, Oct. 30 - Nov. 3, p. 286-289.

Healey, D.L., and C.H. Miller, 1971. Gravity Survey of the Amargosa Desert Area of Nevada and California, U.S. Geological Survey Report USGS-474-136, 29 p. (available only from the U.S. Department of Commerce, National Technical Information Service, Springfield, Virginia, 22151).

Healey, D.L., 1986. Borehole Gravity Meter Survey in Drillhole USW G-4, Yucca Mountain Area, Nye County, Nevada, U.S. Geological Survey Open File Report 86-205, 18 p.

Healey, D.I., F.G. Clustom, and D.A. Glover, 1984, Borehole Gravity Meter Surveys in Drillholes USW G-3, UE25 p\#1, Yucca Mountain Area, Nevada, U.S. Geological Survey Open File Report 84-672, 16 p.

Izett, G.A., R.E. Wilcox, H.A. Powers, and G.A. Desborough, _. "The Bishop Ash Bed, A Pleistocene Marker Bed in the Western United States," Quaternary Research, Interdispl. Jour., vol. 1, no. 1. 
Jones, G.M., M.E. Blackey, J.E. Rice, V.J. Murphy, E.N. Levine, P.S. Fisk, and R.W. Bromery, 1987. Survey of Geophysical Techniques for Site Characterization in Basalt, Salt and Tuff, Weston Geophysical Corp., Westboro, MA, prepared for the U.S. Nuclear Regulatory Commission, NUREG/CR-4957, $138 \mathrm{p}$.

Kane, M.F., and R.E. Bracken, 1983. Aeromagnetic Map of Yucca Mountain and Surrounding Regions, U.S. Geological Survey Open File Report 83-616.

Kane, M.F., M.W. Webring, and B.K. Bhattacharyya, 1981. A Preliminary Analysis of Gravity and Aeromagnetic Surveys of the Timber Mountain Area, Southern Nevada, U.S. Geological Survey Open File Report 81-189, 43 p.

Knuepfer, P.I.K., et al., 1987. "Crustal Structure of the Basin and Range-Sierra Nevada Transition from COCORP Deep Seismic-Reflection Profiling," Geological Soc. of America Bull., vol. 98, p. 488-496.

Mabey, D.R., 1963. "Complete Bouguer Anomaly Map of the Death Valley Region, California," U.S. Geological Survey Geophysical Investigations Map GP-305, scale $1: 250,000$.

McGovern, T.F., 1983. An Evaluation of Seismic Reflection Studies in the Yucca Mountain Area, Nevada Test Site, U.S. Geological Survey Open File Report 83-912, $58 \mathrm{p}$.

Paillet, F.I., 1980. "Acoustic Propagation in the Vicinity of Fractures which Intersect a Fluid Filled Borehole," Trans. SPWLA Annu. Logging Symp., 24 th, DD1-DD33.

Pankratz, L.W., 1982. Reconnaissance Seismic Refraction Studies at Calico Hills, Wahmonie, and Yucca Mountain, Southwest Nevada Test Site, Nye County, Nevada, U.S. Geological Survey Open File Report 82-478, 25 p.

Ponce, D.A., 1981. Preliminary Gravity Investigations of the Wahmonie Site, Nevada Test Site, Nye County, Nevada, U.S. Geological Survey Open File Report $32-931,2332$ p.

Ramirez, A.L., and W.D. Daily, 1987. "Evaluation of Alterant Geophysical Tomography in Welded Tuff," JGR, vol. 92, n. B8, p. 7,843-7,853.

Robison, J.H., _. Ground-Water Level Data and Preliminary PotentiometricSurface Maps, Yucca Mountain and Vicinity, Nye County, Nevada, U.S. Geological Survey Water Resources Investigations Report 84-4197, 8 p.

Robison, J.H., D.M. Stephens, R.R. Luckey, and D.A. Baldwin, 1988. Water Levels in Periodically Measured Wells in the Yucca Mountain Area, Nevada, 1981-1987, U.S. Geological Survey Open File Report 88-468, 132 p.

Rush, F.E., W. Thordarson, and I. Bruckheimer, 1983. Geohydrology of Test Well USW H-1, Yucca Mountain, Nye County, Nevada, U. $\bar{S}$. Geological Survey Water Resources Investigation Report 83-4032, 38 p. 
Scott, R.B., and J. Bonk, 1984. Preliminary Geologic Map of Yucca Mountain, Nye County, Nevada, with Geologic Cross-Sections, U.S. Geological Survey Open File Report 84-494.

Senterfit, R.M., D.B. Hoover, and M. Chornack, 1982. Resistivity Sounding Investigations by the Schlumberger Method in the Yucca Mountain/Jackass Flats Area, Nevada Test Site, Nevada, U.S. Geological Survey Open File Report 82-1043, $38 \mathrm{p}$.

Serpa, L.B., B. deVoogd, L. Wright, J. Willemin, J. Oliver, E. Hauser, and B. Troxel, 1988. Structure of the Central Death Valley Pull-Apart Basin from COCORP Profiles in the Southern Great Basin, Geological Soc. of America Bull., vol. 100, p. 1,437-1,450.

Smith, C., H.P. Ross, and R. Ediquist, 1981. Interpreted Resistivity and IP, Section Line W1, Wahmonie Area, Nevada Test Site, Nevada, U.S. Geological Survey Open File Report 81-1350, 14 p.

Snyder, D.B., and W.J. Carr, 1982. Preliminary Results of Gravity Investigations at Yucca Mountain and Vicinity, Southern Nye County, Nevada, U.S. Geological Survey Open File Report 82-701, 41 p.

Sutton, V.D., 1985. Data Report for the 1985 Seismic Refraction Experiment at Yucca Mountain, Beatty, and Vicinity, Southwestern Nevada, U.S. Geological Survey Open File Report 85-591, 66 p., 11 plates.

USGS (U.S. Geological Survey), 1988. "Geologic and Hydrologic Investigations of a Potential Nuclear Waste Disposal Site at Yucca Mountain, Southern Nevada," U.S. Geological Survey Bulletin 1790, M.D. Carr and J.C. Yount (eds.), $152 \mathrm{p}$.

Waddell, R.K., 1982. Two-Dimensional, Steady-State Model of Ground-Water Flow, Nevada Test site and Vicinity, Nevada-California, U.S. Geological Survey Water Resources Investigations Report 82-4085, 62 p.

Wynn, J.C., and E.H. Roseboom, 1987. "Rose of Geophysics In Identifying and Characterizing Sites for High-Level Waste Repositories," J. Geophysical Research, vol. 92, no. 88, p. 7,789-7,796.

Winograd, I.J., and W. Thordarson, 1975. Hydrogeologic and Hydrochemical Framework, South-Central Great Basin, Nevada-California, with Specjal Reference to the Nevada Test Site, U.S. Geological Survey Professional Paper 712-C, p. C1-C126. 


\subsection{GEOPHYSICAI INTEGRATION AND PRIORITIZAIION OF ACTIVITIES}

The objective of the geophysics integration activity as stated in SCP Section 8.3.1.4.1.2 is to increase the effectiveness of geophysical activities during site characterization by (1) systematic consideration of past results, and (2) analyzing how each planned survey addresses information requirements for site licensing. The integration activity will review and evaluate planned geophysical activities for the following:

1. Consistency with results from past surveys.

2. Direct or supportive uses of the data for site licensing.

3. Identification of techniques that are likely to produce usable data.

4. The need for the planned effort relative to alternative methods for obtaining the information.

5. Scheduling of the planned effort with respect to other studies, and overall priorities for site characterization.

Some of these concerns, particularly items 1 and 3 above, have already been addressed by this report. The SCP program as described in section 3.1 is generally consistent with past results summarized in Chapter 2, insofar a, activities for which definite plans exist have substantial likelihood of providing useable information. Where past results indicate that important methods such as seismic reflection may not produce useable information, the SCP contains plans to conduct organized reviews of the methods and their prospective application.

The status of activities to address other items in the list is discussed in this section, and in sections 3.3 and 3.4. The editors intend for this report to represent the status of geophysical activities approximately one year after release of the statutory SCP. Accordingly, these sections of the: report go beyond the starting point of geophysical integration, stating current working positions on (1) priority activities for the next 1 to 2 years (this section), (2) feasibility testing (see section 3.3), (3) quality assurance for existing data (see section 3.4), and (4) a geophysical activities integration study plan (this section). The positions are essential to coordinate activities that involve different investigators or organizations, to focus resources on characterization priorities, and to expedite further planning and integration. The positions will guide, but not control the site characterization program. The Site Characterization Technical Planning Basis (DOE, 1989) and Study Plans are the basis for controlled planning of specific site characterization activities.

Several topics are identified in SCP section 8.3.1.4.1.2 for intensive review and evaluation. These are (1) subsurface tectonic structure and regional context for the site area, (2) characterization of fractures and fault zones in the repository block, (3) exploration of the large hydraulic gradient area, and (4) detection of potential natural resources. Another key topic that has received recent attention is the distribution and volume of 
volcanic deposits. These five topics are addressed in the preliminary prioritization of geophysical activities that is presented below.

\section{INTERFACES BETWEEN STUDIES}

Recognition of possible interfaces between geophysical activities is provided to initiate a thorough approach to integration and prioritization. A matrix associating SCP Studies with geophysical methods (Figure 3.2-1.), and a table associating planned data collection activities with activities that are sources of planning input (Table 3.2-1), are presented for this purpose.

Figure 3.2-1 is a matrix correlating categories of geophysical methods with the SCP studies that will collect and/or use the resulting data. In addition, the matrix contains letter codes describing the areal extent of the different types of geophysical data needed for each study. Figure 3.2-1 can be used to identify the studies that will implement or use data from a particular geophysical method, and the approximate area of coverage.

Table 3.2-1 contains a more detailed list of associations between activities involving geophysics. The cable is organized in columns, such that the SCP Activities on the left-hand side should consider results or planning input from those on the right-hand side. Interfaces have been identified only for data collection activities, or activities directly affecting plans for geophysical investigations, thus neglecting activities such as synthesis and geologic modeling.

\section{NRC SITE CHARACTERIZATION ANALYSIS (SCA) CONCERNS}

NRC concerns also form part of the basis for prioritizing near-term activities. The SCA (letter: Bernero-to-Rousso, with enclosure, dated 7-31-89) contains several comments that pertain directly to geophysical applications, and to the geophysics integration activity. The following discussion is not an official response to any of the SCA comments, but indicates how the comments are incorporated in the integration positions developed by this report.

\section{Comment 32: Geophysics integration}

This comment criticizes the integration of planned geophysical activities, and the SCP description of the geophysics integration activity (Section 8.3.1.4.1.2). The SCP does not contain a geophysics program per se, because geophysical methods are described in the sections where they are applied. Chapter 2 and section 3.1 of this report address this aspect of the SCP, reviewing the coverage, quality, and applicability of existing data, and relating past results to planned surveys for specific characterization objectives. The information presented in this report indicates that it would be unreasonable to plan a comprehensive program of geophysical data collection, using methods that have not been proven at the Yucca Mountain site or vicinity. In particular, it would be inappropriate 


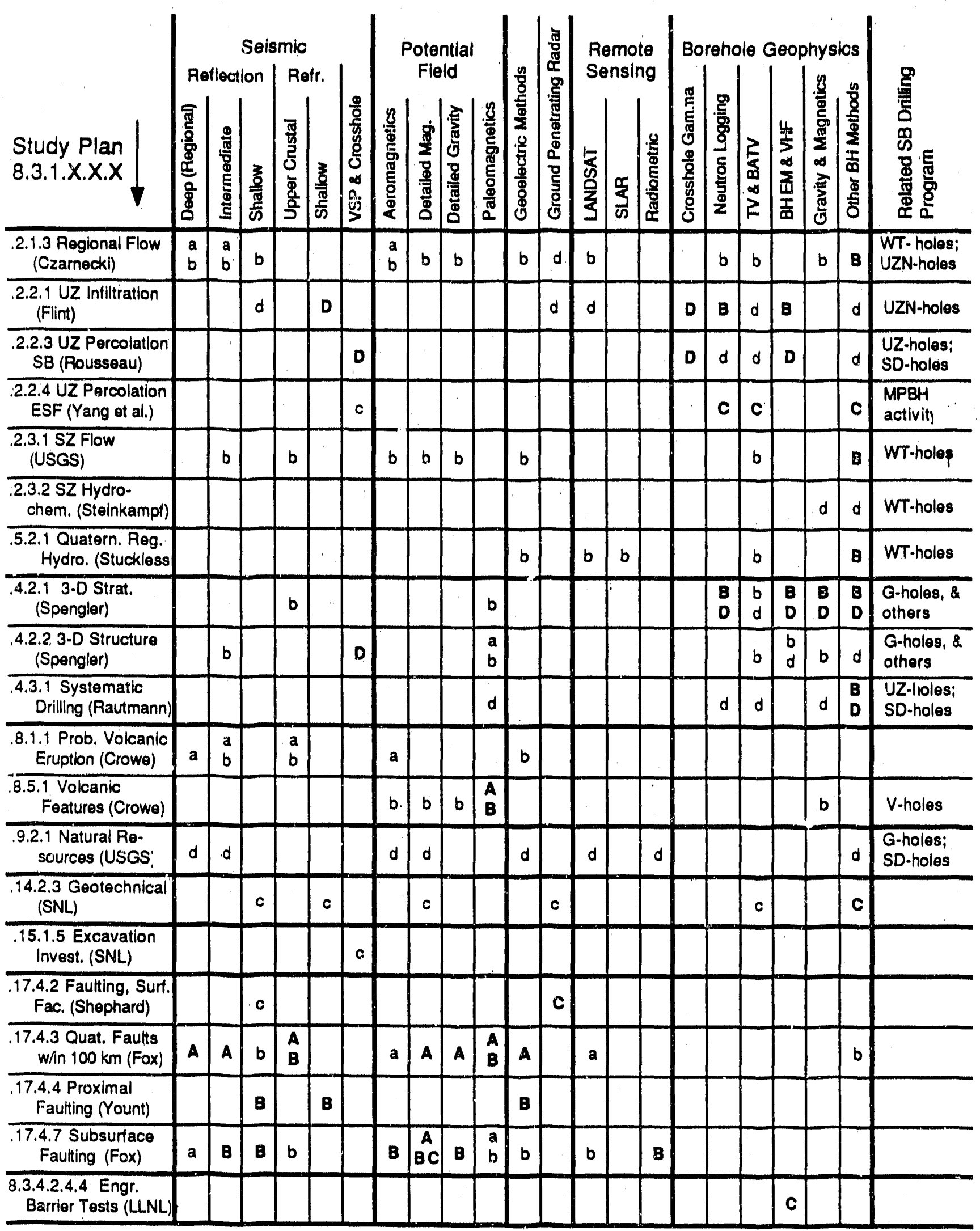

NOTES:

(1) $a=$ Regional, $b=$ Yucca Mtn \& vicinity, $c=$ Surface facilities, $d=$ Repository block \& vicinity.

(2) CAPITALIZED indicates actual data collection activities, vs. studies where geophysical data are used.

Figure 3.2-1. Matrix correlating categories of geophysical methods, with SCP studies wherein geophysical data will be collected and used. 
Table 3.2-1. Interfaces Between Geophysical Activities, Arranged by SCP Activity (Page 1 of 6 )

SCP Activity: Gp Application: Input From:

REGIONAL HYDROLOGY

\begin{tabular}{|c|c|c|c|c|}
\hline $8.3 \cdot 1.2 .1 .3 .1$ & $\begin{array}{l}\text { trace impermeable } \\
\text { near-surface strata }\end{array}$ & $\begin{array}{l}<- \\
<-\end{array}$ & 8.3 .1 .4 .2 .1 .3 & borehole geophysics \\
\hline $8 \cdot 3 \cdot 1 \cdot 2 \cdot 1 \cdot 3 \cdot 2$ & $\begin{array}{l}\text { borehole logging, } \\
\text { non-Project welis }\end{array}$ & $\begin{array}{l}<- \\
<- \\
<-\end{array}$ & $\begin{array}{l}8 \cdot 3 \cdot 1 \cdot 4 \cdot 2 \cdot 1 \cdot 3 \\
8.3 \cdot 1 \cdot 4 \cdot 2 \cdot 2 \cdot 3 \\
\operatorname{logs}\end{array}$ & $\begin{array}{l}\text { borehole geophysics } \\
\text { BATV, flowmeter }\end{array}$ \\
\hline 8.3 .1 .2 .1 .3 .2 & $\begin{array}{l}\text { regional potentio- } \\
\text { metric surface }\end{array}$ & $\begin{array}{l}<- \\
<-\end{array}$ & 8.3 .1 .4 .2 .1 .2 & $\begin{array}{l}\text { surface-based } \\
\text { geophysics }\end{array}$ \\
\hline $8.3 \cdot 1.2 \cdot 1 \cdot 3 \cdot 3$ & $\begin{array}{l}\text { Fortymile Wash } \\
\text { recharge studies }\end{array}$ & $\begin{array}{l}<- \\
<- \\
<- \\
<- \\
<- \\
<- \\
<- \\
<- \\
<- \\
<-\end{array}$ & $\begin{array}{l}8.3 .1 .2 .2 .1 .2 \\
8.3 .1 .4 .2 .1 .3 \\
8.3 .1 .2 .2 .2 .3 \\
8.3 .1 .2 .2 .3 .2\end{array}$ & $\begin{array}{l}\text { natural infiltration } \\
\text { study, geophysics } \\
\text { applications } \\
\text { borehole geophysics } \\
\text { borehole eval. of } \\
\text { fallts/fractures } \\
\text { site vertical } \\
\text { boreholes study; } \\
\text { geophysics } \\
\text { applications }\end{array}$ \\
\hline
\end{tabular}

UZ HYDROLOGY

\begin{tabular}{|c|c|c|c|c|}
\hline 8.3 .1 .2 .2 .1 .1 & $\begin{array}{l}\text { characterize } \\
\text { hydrologic } \\
\text { properties of } \\
\text { surficial materials }\end{array}$ & $\begin{array}{l}<- \\
<- \\
<- \\
<- \\
<- \\
<-\end{array}$ & $\begin{array}{l}8.3 .1 .4 .2 .2 .3 \\
8.3 .1 .17 .4 .2 .1 \\
8.3 .1 .17 .4 .4 \\
8.3 .1 .17 .4 .7 .8\end{array}$ & $\begin{array}{l}\text { borehole eval. of } \\
\text { faults/fractures } \\
\text { ground-based radar } \\
\text { shallow refraction } \\
\text { for fault char. } \\
\text { Mini-Sosie tests }\end{array}$ \\
\hline 8.3 .1 .2 .2 .1 .1 & $\begin{array}{l}\text { hydrologic props. } \\
\text { of surficial } \\
\text { materials; airborne } \\
\text { radar (SLAR) }\end{array}$ & $\begin{array}{l}<- \\
<- \\
<- \\
<-\end{array}$ & $\begin{array}{l}8.3 \cdot 1.2 .1 .3 .2 \\
8.3 .1 .5 .2 .1 .3\end{array}$ & $\begin{array}{l}\text { investigate hydro. } \\
\text { significance of } \\
\text { lineaments } \\
\text { regional hydrology }\end{array}$ \\
\hline 8.3 .1 .2 .2 .1 .2 & natural infiltration & $\begin{array}{l}<- \\
<- \\
<- \\
<-\end{array}$ & 8.3 .1 .4 .2 .1 .3 & $\begin{array}{l}\text { borehole Gp } \\
\text { (calibration holes; } \\
\text { analysis of wireline } \\
\text { responses) }\end{array}$ \\
\hline 8.3 .1 .2 .2 .3 .1 & $\begin{array}{l}\text { matrix hydrologic } \\
\text { properties from } \\
\text { core/cuttings }\end{array}$ & $\begin{array}{l}<- \\
<- \\
<- \\
<-\end{array}$ & $\begin{array}{r}8.3 \cdot 1 \cdot 4 \cdot 2 \cdot 1 \cdot 3 \\
88.3 \cdot 1 \cdot 4 \cdot 2 \cdot 2 \cdot 4\end{array}$ & $\begin{array}{l}\text { use borehole } \\
\text { geophysics to } \\
\text { establish context } \\
\text { of samples }\end{array}$ \\
\hline
\end{tabular}


Table 3.2-1. Interfaces Between Geophysical Activities, Arranged by SCP Activity (Page 2 of 6 )

SCP Activity: Gp Application: Input From:

\begin{tabular}{|c|c|c|c|c|}
\hline 8.3 .1 .2 .2 .3 .2 & $\begin{array}{l}\text { crosshole gamma } \\
\text { transmission }\end{array}$ & $\begin{array}{l}<- \\
<- \\
<-\end{array}$ & 8.3 .1 .2 .2 .1 .2 & $\begin{array}{l}\text { experience acquired } \\
\text { from infiltration } \\
\text { monitoring program }\end{array}$ \\
\hline 8.3 .1 .2 .2 .3 .2 & VSP application & $\begin{array}{l}<- \\
<-\end{array}$ & 8.3 .1 .4 .2 .2 .5 & $\begin{array}{l}\text { VSP feasibility } \\
\text { testing }\end{array}$ \\
\hline 8.3 .1 .2 .2 .4 & $\begin{array}{l}\text { hydrologic testing } \\
\text { in the ESF }\end{array}$ & $\begin{array}{l}<- \\
<- \\
<- \\
<- \\
<- \\
<- \\
<- \\
<- \\
<-\end{array}$ & 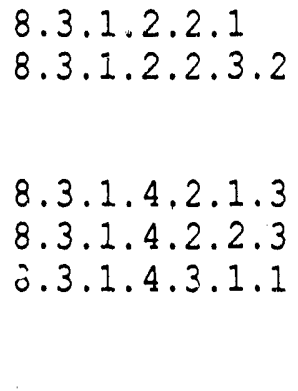 & $\begin{array}{l}\text { infiltration studies } \\
\text { logging, fracture } \\
\text { characterization } \\
\text { techniques } \\
\text { borehole geophysics } \\
\text { crosshole methods } \\
\text { systematic drilling } \\
\text { program baseline } \\
\text { log suite }\end{array}$ \\
\hline
\end{tabular}

SZ HYDROLOGY, SITE
8.3 .1 .2 .3 .1
Sz well
testing in the
$<-8.3 .1 .4 .2 .1 .3$
borehole geophysics
"c-wells" and other
$<-8.3 .1 .4 .2 .2 .3$
borehole evaluation
boreholes
$<-$
$<-8.3 .1 .4 .2 .2 .5$
of faults, fractures
VSP testing

SITE STRATIGRAPHY AND STRUCTURE
8.3.1.4.2.1.2 surface-based Gp incl. planned refraction profile across northern YM
$8.3 .1 .4 .2 .1 .3 \&$
8.3.1.4.2.2.3
borehole Gp \&
borehole evaluation of faults/fractures

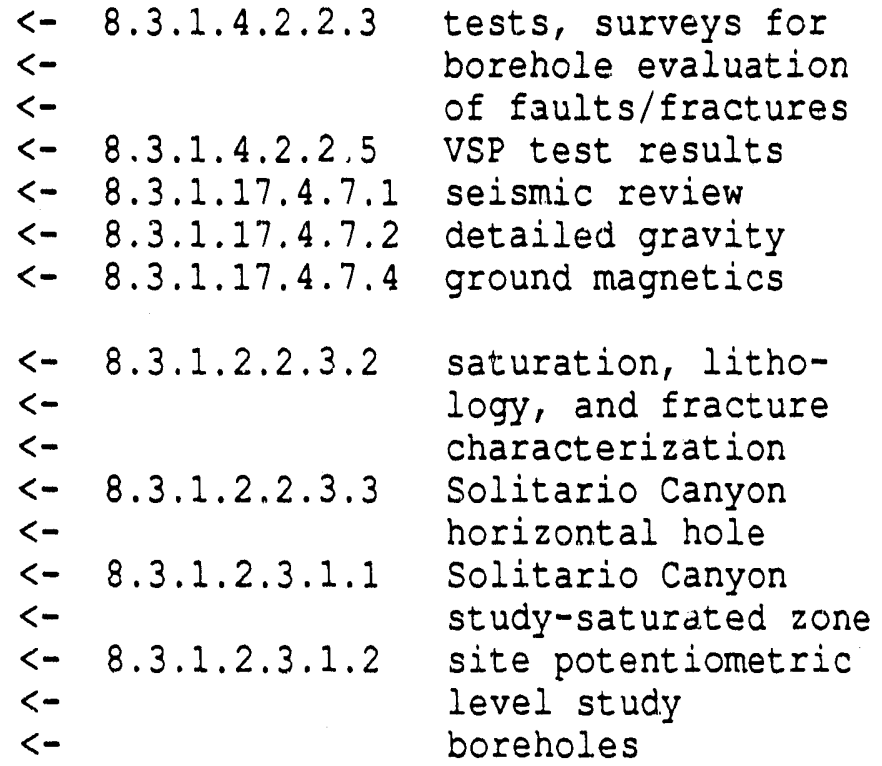


Table 3.2-1. Interfaces Between Geophysical Activities, Arranged by SCP Activity (Page 3 of 6 )

SCP Activity: Gp Application: Input From:

\begin{tabular}{|c|c|c|c|c|}
\hline 8.3 .1 .4 .2 .1 .3 & $\begin{array}{l}\text { borehole gravimetry } \\
\text { and density logging }\end{array}$ & $\begin{array}{l}<- \\
<-\end{array}$ & 8.3 .1 .17 .4 .7 .2 & detailed gravity \\
\hline 8.3 .1 .4 .3 .1 .1 & $\begin{array}{l}\text { systematic drilling } \\
\text { program baseline } \\
\text { log suite }\end{array}$ & $\begin{array}{l}<- \\
<- \\
<-\end{array}$ & $\begin{array}{l}8.3 \cdot 1 \cdot 4 \cdot 2 \cdot 1 \cdot 3 \\
8.3 \cdot 1.4 .2 .1 .5\end{array}$ & $\begin{array}{l}\text { borehole geophysics } \\
\text { magnetic strati- } \\
\text { graphy }\end{array}$ \\
\hline $8.3 .1 .4 .3 \cdot 1 \cdot 1$ & $\begin{array}{l}\text { systematic drilling } \\
\text { program borehole } \\
\text { planning }\end{array}$ & $\begin{array}{l}<- \\
<- \\
<-\end{array}$ & 8.3 .1 .4 .2 .2 .5 & $\begin{array}{l}\text { VSP feasibility } \\
\text { testing }\end{array}$ \\
\hline
\end{tabular}

ENGINEERING PROPERTIES OF SURFICIAI MATERIALS

\begin{tabular}{|c|c|c|c|c|}
\hline 8.3 .1 .14 .2 .3 & $\begin{array}{l}\text { engineering } \\
\text { characterization of } \\
\text { surficial materials }\end{array}$ & $\begin{array}{l}<- \\
<- \\
<- \\
<- \\
<- \\
<- \\
<- \\
<- \\
<- \\
<- \\
<-\end{array}$ & 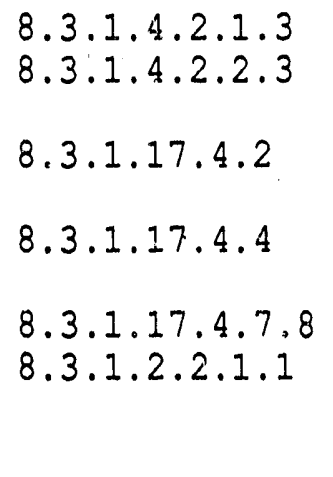 & $\begin{array}{l}\text { borehole geophysics } \\
\text { boreho? eval. of } \\
\text { faults/fractures } \\
\text { GPR testing at } \\
\text { Midway Valley } \\
\text { shallow refr. for } \\
\text { fault char. } \\
\text { Mini-sosie tests } \\
\text { Gp char. of hydro. } \\
\text { props. of surficial } \\
\text { materials }\end{array}$ \\
\hline
\end{tabular}

THERMAL/MECHANICAL ROCK PROPERTIES
8.3,1.15.1.1.1 density, porosity <- 8.3.1.4.2.1.3 use borehole and other props. <- \&8.3.1.4.2.2.4 geophysics from core samples <- to establish
$<-\quad$ context of samples

PRECLOSURE TECTONICS

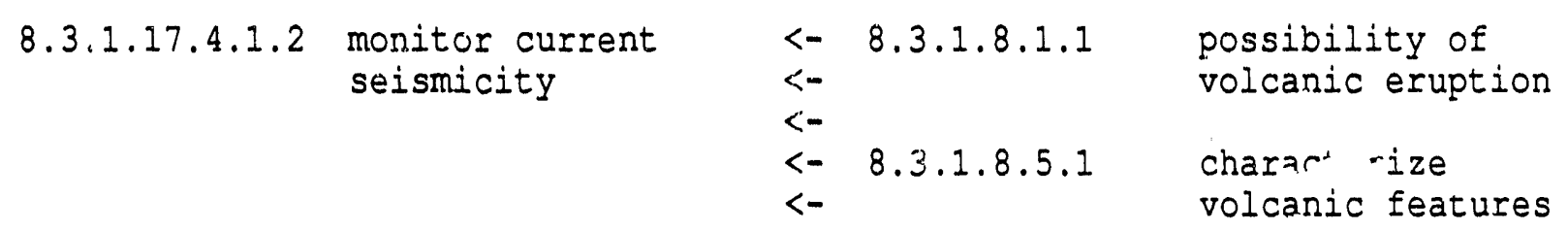


Table 3.2-1. Interfaces Between Geophysical Activities, Arranged by SCP Activity (Page 4 of 6 )

SCP Activity: Gp Application: Input Erom:

8.3.1.17.4.3.1 regional Gp lines

$<-8.3 .1 .2 .1 .3 .1$ characterize channel

$<-$

$<-8.3 .1 .2 .1 .3 .2$

fill

$<-$

$<-8.3 .1 .8 .1 .1$

characterize prem

$<-$

$<-$

$<-8.3 \cdot 1.8 \cdot 5 \cdot 1$

Tertiary rocks

evaluate structural

$\square$

$<-$

$<-$

8.3 .1 .9 .2 .1 .4

controls on basaltic

volcanism

$<-$

8.3.1.17.4.3.2 paleomagnetism studies on faults

$<-$

$<-8.3 .1 .8 .5 .1$

characterize

volcanic features

evaluate hydrocarbon

potential at the

site

$\mathrm{w} / \mathrm{in} 100 \mathrm{~km}$

$<-$

$<-$

$<-$

8.3 .1 .2 .1 .3 .2

studies to

characterize

volcanic features

$<-$

investigate hydro.

significance of

$<-$

$<-$

$8 \cdot 3 \cdot 1 \cdot 5 \cdot 2 \cdot 1 \cdot 3$

lineaments

$<-$

8.3 .1 .17 .4 .3 .5

LANDSAT thematic

$<-$

8.3 .1 .2 .2 .1 .1

regional surface

hydrology

mapper investigation

$<-$

characterize-

hydrologic

properties of

surficial materials

$<-$

8.3.1.2.1.3.2

investigate

hydro, significance

$<-$

$<-$

of lineaments

$8.3 \cdot 1.5 \cdot 2 \cdot 1.3$

regional surface

$<-$

$<-$

hydrology

8.3.1.17.4.3.2 study of faults $w /$ in

$100 \mathrm{~km}$ of $\mathrm{YM}$

$<-$

8.3 .1 .17 .4 .9 .1

desert varnish

studies

8.3 .1 .17 .4 .4

detailed studies of

faults in the $\mathrm{YM}$

$<-$

8.3 .1 .17 .4 .7 .8

results from region

Mini-Sosie tests

8.3.1.17.4.7.1 review of inter-

mediate depth

seismic methods

$<-$

$<-$

$<-8.3 \cdot 1 \cdot 2 \cdot 3 \cdot 1.2$

site potentiometric level-study of large

$<-$

$<-$

$<-$

8.3 .1 .8 .5 .1

hydraulic gradient

$<-$

data needs for

study of volcanic

features

$<-\quad 8.3 .1 .9 .2 .1 .4$

data needs to assess

$<-$

energy resources 
Table 3.2-1. Interfaces Between Geophysical Activities, Arranged by SCP Activity (Page 5 of 6 )

SCP Activity: Gp Application: Input From:

8.3.1.17.4.7.2 detailed gravity

8.3.1.17.4.7.3\& detailed aeromag.; 8.3.1.17.4.7.4 ground magnetics

8.3.1.17.4.7.5 review of geoelectric methods

8.3.1.17.4.7.6 airborne and ground gamma-ray tests, surveys
$<-8.3 \cdot 1 \cdot 8 \cdot 1.1$

$<-$

$<-$

$<-8.3 .1 .9 .2 .1 .2$

$<-$

$<-$

$<-$

$<-8.3 .1 .2 .3 .1 .2$

$<-$

$<-$

$<-$

$<-$

$<-$

$<-$

$<-$

$<-$

$<-$

$<-$

$<-$

$<-$

$<-$

$<-$

$<-$

$<-$

$<-$

$<-$

$<-$

$<-$

$<-$

$<-$

$<-$

$<-$

$<-$

$<-$

$<-$

$<-8.3 .1 .17 .4 .3 .2$

$<-$

$<-8.3 .1 .17 .4 .2 .1$

$<-$

$<-$ evaluate structural controls on basaltic volcanism geophysical appraisal of the site relative to mineral resources

site potentiometric level-large hydraulic gradient evaluate structural controls on basaltic volcanism characterize volcanic features geophysical appraisal of the site relative to mineral resources airborne radioactivity survey (may share platform)

characterize preTertiary rocks site potentiometric level-data needs for study of large hydraulic gradient map regional water table variation characterize volcanic features geophysical appraisal of mineral and hydrocarbon resources

study of faults $w /$ in $100 \mathrm{~km}$ of $\mathrm{YM}$

faulting studies for surface facilities siting 
Table 3.2-1. Interfaces Between Geophysical Activities, Arranged by SCP Activity (Page 6 of 6 )

SCP Activity: Gp Application: Input From:

8.3.1.17.4.7.7 thermal infra-red $<-8.3 .1 .2 .1 .3 .2$ investigate

lineaments with

potential hydrologic

$\begin{array}{ll}<- & \begin{array}{l}\text { significance } \\ \text { hydrologic }\end{array}\end{array}$

<- properties of

$<-\quad$ surficial materials

$<-8.3 .1 .5 .2 .1 .3$ regional surface

$<-\quad$ hydrology 
to embark on a 3-D seismic reflection program, given that no reflection event has ever been positively identified from any surface or downhole seismic survey at Yucca Mountain (see Section 2.5). When planned feasibility tests and initial data collection activities have been performed and evaluated, a balanced approach to seismic exploration can be implemented.

Use of complementary geophysical methods has been incorporated into the program for objectives such as fault detection, characterization of volcanic features, and exploration of the large hydraulic gradient area (see Section 3.1). Several planned feasibility tests (see Section 3.3) will evaluate methods that could become additional complementary methods to address these objectives.

Comment 51: Geophysics integration, local and regional scales

The planned gravity, aeromagnetic, geoelectric, seismic reflection, and seismic refraction surveys described by this report are the basis for an "integrated" geophysics program that can accomplish both regional reconnaissance and focused investigation of the site area. The teleseismic data collection and analysis activity described in Section 3.1 will also provide areally extensive reconnaissance. (Applications of seismic and geoelectric methods have yet to be reviewed as planned in SCP Studies 8.3.1.17.4.3 and 8.3.1.17.4.7). These data sets together are expected to improve understanding and interpretation of the isostatic gravity anomaly, depth to the Curie isothelm, crustal conductivity structure, seismic Moho, crustal and upper mantle velocity structure, and the geometry of upper- to mid-crustal reflectors and their assocation with structure at the surface. Implementation and possible elaboration of parts of this program, including 3-D seismic reflection, depends on the results from planned peer review, feasibility testing, and initial data collection and analysis.

Comment 52: Geophysical surveys for characterization of igneous activity

This report contains several new concepts for investigation of volcanic deposits and magmatic intrusions. The integrated program that will be elaborated in several different Study Plans, includes feasibility testing of gravity and ground magnetic methods for delineating known volcanic features, expanded coverage for the detailed aeromagnetic survey (based on the feasibility test results), detailed gravity and ground magnetic surveys over known or suspected volcanic deposits, and high-resolution teleseismic data collection and velocity modeling. This program will include data modeling and analysis, and will have high priority as discussed below.

Comment 53: Geophysical surveys for mineral and energy resource assessment

No geophysical investigations are currently planned which will specifically address data needs for natural resource assessment. Current plans adhere to the SCP which states or implies that geophysical data collected and interpreted for characterization of volcanism, tectonics, the large-hydraulic gradient, and fault 
detection/delineation will be evaluated, and are considered adequate for an initial assessment. Activities which will provide the data in question, particularly aeromagnetic surveys and seismic surveys, with the associated feasibility testing, interpretation, and peer review tasks, will be given high priority as discussed below.

The rationale for withholding more extensive geophysical exploration for natural resources includes: (1) needed scoping analyses and models for characteristic geophysical responses are as yet unavailable; and (2) uncertainty of geologic parameters that would be addressed by geophysical exploration in addition to that already planned for other activities, could be small relative to other uncertainties in natural resource assessment that site exploration cannot address. The latter rationale means that without an initial assessment based on new geophysical data, there is significant likelihood that no improvement in estimates of the probability of human intrusion would be gained from extensive site exploration for the natural resources program.

Comment 59: Fault detection, repository surface facilities location

Geophysical methods appear to be of limited usefulness for locating fault offsets in alluvium prior to trenching. For reasons discussed in Sections 2.4 and 2.5 of this report, the alluvium-bedrock contact may not be a strong enough seismic reflector or refractor for reliable profiling. Signal strength and interpretability are further complicated by irregular contact geometry and interbedding in the alluvium. Useful contrasts in geoelectric properties have not been recognized. Certain techniques have not been tried, such as shallow geoelectrical soundings and low-energy seismic reflection (e.g., using shear wave sources), but do not seem likely to image fault offsets at the required resolution. The current strategy for characterizing faulting in Midway Valley relies heavily on trenching, but geophysics will be used if appropriate applications can be demonstrated (e.g., GPR and Mini-Sosie; see sections 3.1.4 and $3.1 .6)$.

Geophysical methods that may be useful for detecting the presence of small faults or associated fracture zones in the waste storage areas of the host rock, will be tested during the planned feasibility testing discussed below.

\section{ACTIVITY PRIORITIZATION}

The basis for preliminary prioritization of activities includes (1) resolution of uncertainty in applicability of geophysics to various planned activities in the SCP, (2) the schedule for site characterization as represented in the SCP, (3) the need to reduce uncertainty in technical plans for characterization activities, (4) NRC SCA Comments, and (5) other recent regulatory interactions. These influences are considered in the following discussion of priorities organized within specific topics. Also, it is important to recognize that a systematic effort to set priorities for 
surface-based testing, in a manner that will provide data for evaluating siting criteria of 10 CFR 60.122 , is underway at the time of publication of this report.

\section{Subsurface Structure of the Yucca Mountain Site Area and Region}

Geophysical data are needed to evaluate alternative conceptual models for tectonic structure at the site, for example, models predicting different geometry for major faults at depth. Present understanding of geologic structure below about $2 \mathrm{~km}$ depth at the site is based mostly on geologic inference, constrained by gravity interpretation, preliminary results from seismic refraction, and a few boreholes one of which penetrates the Paleozoic-Tertiary contact. Activities to better constrain subsurface structure beneath the site, and to establish the regional tectonic context of the structure, have high priority because of the many potential applications of the geologic model, notably in characterizing the saturated carbonate aquifer, and assessing the potential for natural resources. Geophysical exploration of subsurface structure at different scales is also needed to address NRC SCA Comment \#51.

The first priority is to initiate peer reviews pertaining to the following activities:

Peer Review of Applicability of Regional Geophysical Traverses (Activity 8.3.1.17.4.3.1) - This review will consider alternative regional structural hypotheses that can be tested by use of regional geophysical traverses, and evaluate the usefulness of available geophysical techniques for addressing these hypotheses. The assessment will make use of existing geophysical data collected from Death Valley, the Amargosa Desert, intervening ranges, and other venues. The importance of regional geophysical traverses, relative to intersecting traverses in the site vicinity, for detecting and understanding structures that could significantly affect site suitability, will also be assessed. It is anticipated that this review will provide guidance on technical issues that are of considerable importance to site characterization, such that it will be an independent peer review involving experts in regional. tectonics, and geophysical exploration for crustal studies and resource development in the Great Basin.

Peer Review of Seismic Methods for Characterizing Yucca Mountain and Vicinity (Activity 8.3.1.17.4.7.1) - This review will consider the applicability of high-resolution upper-crustal seismic refraction, and seismic reflection methods for structural profiling across yucca Mountain and in adjacent alluvium covered areas. The review will consider the available geophysical data from the site vicinity, and the objectives for seismic exploration for site characterization. It is anticipated that the review will recommend a phased exploration program, that includes specific recommendations on how and where to carry out the first phase and how to carry out subsequent phases based on interim results. The first phase of exploration would be implemented as the seismic reflection feasibility test described in Section 3.3 of this report. 
Because of past results from seismic reflection campaigns at Yucca Mountain (see Sections 2.5 and 3.1 of this report) there is a significant possibility that future surveys will produce no useful results from the site. It is therefore important to solicit special expertise for the review, particularly in the area of seismic reflection exploration of Great Basin volcanic terranes. The review will be an independent peer review involving experts in seismic reflection and refraction, VSP, and geophysical exploration (such as potential methods) in Great Basin volcanic terranes.

The Peer Review of Seismic Methods may also consider the need for VSP in the site area (e.g., borehole USW G-4) or in Crater Flat (e.g., borehole USW $\mathrm{VH}-1)$. At present, there have been no interpretable seismic reflection records obtained from the site area. Regardless of whether VSP is recommended by the peer review in regard to structural profiling, a VSP survey should be conducted and analyzed to determine the importance of layer velocities, reflection coefficients, attenuation, and other effects (e.g., mode conversion, splitting) in the tuff section, to the proposed feasibility test involving a reflection profile across Yucca Mountain.

The objective described above for VSP survey will be met by the VSP feasibility test that has already been planned for borehole USW G-4 (in support of SCP Activity 8.3.1.4.2.2.5). Planning documentation for this test has already received $Q A$ approval, and the major impediment to performance of the test is site access. The test has high priority because it will produce information that supports survey design and interpretation for structural profiling at the site. Applicability of the VSP test to seismic reflection profiling will be further reviewed informally by the geophysics integration activity (SCP section 8.3.1.4.1.2).

Depending on the recommendations of the Peer Review of Seismic Methods, a seismic reflection feasibility test will be performed, involving a reflection line across Crater Flat, Yucca Mountain, Midway Valley, and (partially) Jackass Flats. A coordinated program involving downhole velocity surveys, VSP surveys, noise studies, or source studies may be recomnended by the peer review. It is appropriate to make the reflection test contingent on the peer review because of the potential cost of the seismic line and associated testing activities.

Depending on the recommendations from the Peer Review of Seismic Methods, the planned reversed, east-west seismic refraction line across the northern part of Yucca Mountain (SCP Figure 8.3.1.4-6) will be acquired as planned for study 8.3.1.4.2.1. This line may provide information on the presence of buried structure, such as an igneous intrusion, that could be a cause of the large hydraulic gradient.

Another priority will be to support the program of teleseismic data collection and inversion described in section 3.1 of this report. This program will investigate lateral variability of the lower, middle, and upper crust in the Yucca Mountain region. The area of detailed investigation will include Yucca Mountain, Crater Flat, Jackass Flats, and the portion of the Amargosa Desert where volcanic deposits are evident from aeromagnetic data. 
For a similar purpose, data requirements for detailed Curie isotherm calculations for the Yucca Mountain region will be determined for use in scoping aeromagnetic data collection activities. The teleseismic inversion and magnetic continuation methods are important sources of information on the spatial distribution of crustal properties, that can be used to tie deep crustal features with surface features.

The geoelectric data scoping analysis identified in section 3.3 will have high priority so that the resulting information can be assessed in the planned review of geoelectric applications in site characterization (SCP Activity 8.3.1.17.4.7.5). This latter review (described in the SCP) will be an internal Project activity which assesses the most current information on applicability of geoelectric methods to site characterization, and recommends specific surveys as appropriate. The review and recommendations are needed as soon as practicable, to assure that geoelectric methods are used effectively in site characterization. The review may be followed by appropriate updates to the SCP and Study Plans.

Finally, qualification of the data from the Amargosa Valley seismi: reflection test line will have high priority. The qualification process represented by procedure AP5.92, and the candidate data sets for qualification, are discussed in more detail in Section 3.4 of this report.

\section{Distribution of Volcanic Deposits}

Geophysical characterization of the subsurface extent, and total volume of volcanic deposits in the northern Amargosa Desert including Crater Flat, is a high priority because of public awareness of relatively recent volcanism at the Lathrop Wells cone, because of NRC staff criticism of the approach taken by the Project toward volanic hazard assessment, and the sensitivity of that approach to definition of the domain of existing volcanic deposits. The work is also important for addressing NRC SCA Comment \#52.

It may be appropriate to extend the coverage of the planned detailed aeromagnetic survey (Activity 8.3.1.17.4.7.4) to include the region where existing aeromagnetic data indicate the presence of surface and buried volcanics. The objectives for this coverage would be to provide additional constraint for estimating the total volume of these deposits, and for locating boreholes to sample buried volcanic rocks in the Amargosa Desert. However, there are technical factors which complicate the application of aeromagnetic survey to this purpose. The magnetic properties of the basalt and basaltic detritus may vary significantly throughout the deposits, with the possibility of strongly varying remanence. Also, it is likely that some of the deposits exhibit strong magnetic reversal.

Before embarking on an extensive program of data collection and analysis for volcanism studies, a feasibility test of gravity and ground magnetic methods will be conducted in the vicinity of particular known or suspected volcanic deposits in the area. The scope of this test. will be limited to investigation of a feature or features that are likely to provide adequate information for evaluating the characterization approach using gravity and magnetics. Samples of material will be collected for magnetic analysis, and certain deposits will be more extensively sampled to assess the variability of magnetic properties. Ground surveys will be performed to evaluate whether 
the orientation and extent of feeder dikes can be detected geophysically, and to evaluate differences between ground and airborne surveys. Scoping calculations will be performed to determine the sensitivity of deposit volume estimates, borehole location strategies, and other applications based on different types of data, to uncertainty in the magnetic properties and geometrical approximations needed, to model volcanic deposits.

Based on the results of the feasibility test, the area of coverage for the detailed aeromagnetic survey (SCP Activity 8.3.1.17.4.7.4) will be increased as indicated in Section 3.1 of this report, with a concomitant program of sampling, modeling, and interpretation.

The planned seismic reflection feasibility test will investigate whether (1) the known, buried basalts in Crater Flat produce interpretable reflections; and (2) whether seismic reflection can penetrate below such deposits. This evaluation will require that the feasibility test line be routed proximally to existing boreholes $\mathrm{VH}-1$ and $\mathrm{VH}-2$, and that downhole geophones be used to the extent practicable in VH-1 (which is available for this purpose).

Finally, the teleseismic data collection and inversion activity discussed in sections 2.8 and 3.1 of this report, will be planned and implemented as a reconnaissance tool in the volcanism investigation.

\section{Exploration of the Large Hydraulic Gradient Area}

The cause or source of the large hydraulic gradient is important for assessment of postclosure repository performance. The altitude of the water table 1 to $2 \mathrm{~km}$ north of the site is roughyl comparable to, or greater than, the elevation of a portion of the conceptual repository. Additional information is needed to evaluate the credibility of the repository flooding scenario. It is anticipated that a major part of this information will come from borehole exploration and testing, and that preliminary findings from investigation of the large hydraulic gradient will be published early in site characterization (SCP Study 8.3.1.2.1.3, page 8.3.1.2-449). Accordingly, geophysical reconnaissance of the area, principally for use in siting exploratory boreholes, is a high priority. Such surveys are related to exploratory drilling planned for SCP studies 8.3.1.2.1.3, 8.3.1.2.3.1, and 8.3.1.4.2.1.

Applicable reconnaissance methods include aeromagnetic (SCP Activity 8.3.1.17.4.7.2), seismic refraction (Activity 8.3.1.4.2.1.2), geoelectric soundings (Activity 8.3.1.17.4.7.5) and detailed gravity (Activity 8.3.1.17.4.7.2). As shown in the SCP, detailed gravity and aeromagnetic coverage will encompass the large hydraulic gradient area from Fortymile Wash to the western edge of northern Yucca Mountain. These surveys have high priority with respect to investigation of the large hydraulic gradient.

The planned east-west high-resolution, upper-crustal seismic refraction line across northern Yucca Mountain (SCP Activity 8.3.1.4.2.1.2) is needed to test for a velocity anomaly that could be associated with a structural origin for the large hydraulic gradient. Similarly, a program of magnetotelluric (MT) soundings along traverses perpendicular to the hydraulic gradient inferred from boreholes, is proposed as a feasibility test of the 
applicability of this method for detecting a possible structural origin (see Section 3.3 of this report). The proposed MT traverses will not depend on the performance or the outcome of the planned review of the applications of geoelectric methods to site characterization (SCP Activity 8.3.1.17.4.7.5) discussed above. This is because the existing geoelectric data are not adequate for assessing the applicability of these methods to the important objective of exploring the large hydraulic gradient area.

Finally, the feasibility testing program discussed in section 3.3 also includes investigations to determine the applicability of detailed gravity methods to exploration of the large hydraulic gradient area and other features. As discussed in sections 2.1 and 3.1 there is local variation of gravity in the area, but data acquisition and terrain correction accuracy are hindered by rugged topography and limited access. Several high-resolution gravity profiles will be collected along roads traversing the area. Acquisition and interpretation of these profiles will permit timely assessment of the importance of detailed gravity to the large hydraulic gradient investigation.

\section{Characterization of Fractures and Fault Zones in the Repository Block}

The nature of fracturing and fault zones in the repository block is important for understanding the hydrology of the UZ, for repository design, and for assessing the effect of these features on the integrity of emplaced waste containers. Seismic propagation is probably the principal geophysical response by which such features of the rock mass can be detected or characterized noninvasively. Depending on the amount of vadose water or mineral alteration that may be associated with moisture movement along fracture pathways, geoelectric response may also be indicative of such features. Because of the large distances separating boreholes over most of the site, the rugged surface conditions, and current uncertainty as to the geophysical response of fractures and fault zones at Yucca Mountain, surface-to-borehole techniques and large-spacing borehole logs are most appropriate for testing.

Current plans call for a VSE feasibility test in borehole USW G-4 using vibrator sources at multiple offsets (SCP Activity 8.3.1.4.2.2.5). The casing will be removed from this borehole prior to testing. Results from this test are important not only for conducting seismic experiments involving the exploratory shaft, but also for planning VSP surveys in the Uz hydrology boreholes (ECP Activity 8.3.1.2.2.3.2), specifying geophysical surveys to be performed in boreholes of the systematic drilling program (see SCP Activity 8.3.1.4.2.2.3), and design of the feasibility test of seismic reflection profiling across Yucca Mountain.

It is important to determine what methods will be used to characterize rock mass conditions throughout the repository block, so that the boreholes drilled for the UZ hydrology program and the systematic drilling program (comprising most of the planned penetrations) can be used for geophysical characterization prior to completion for other uses. Accordingly, the feasibility of large-spacing electromagnetic (EM) and electrical resistivity (ER) logs and borehole-to-surface surveys for fracture and fault zone characterization will be tested at an appropriate location (see section 3.3 of this report). 
The DOE recently conducted a review of geological and geophysical data pertaining to structural geology at the proposed location of the Exploratory Shaft Facility (ESF) in Coyote Wash (reference: Technical Assessment Review of Geologic and Geophysical Evidence Pertaining to Structural Geology in the Vicinity of the Proposed Exploratory Shaft, YMP/90-2). The review activity focused on the likelihood of an unmapped fault within $100 \mathrm{ft}$ of either shaft location. The Technical Assessment Review (TAR) produced several recommendations, including possible additional drilling and geophysical data collection. It was determined that needed information on the possible existence of a fault at the surface could be obtained by geologic mapping before and during construction of the facility. However, additional resistivity and EM lines were recommended in conjunction with shallow surveys to determine depth-to-bedrock in Coyote Wash, to investigate whether a buried fault (concealed by deposition of more recent Miocene ash flow deposits) exists at the location. The determination of whether there is sufficient likelihood of a buried fault to merit additional geophysical exploration, is poorly constrained by existing geophysical data and must be based principally on geologic inference. This determination will be solicited from the DOE, and, if appropriate, the recommended data collection and analysis activities will receive high priority.

\section{Assessment of the Potential for Natural Resources}

In accordance with the SCP description of Study 8.3.1.9.2.1, no new geophysical data are currently planned for natural resource assessment for reasons given in a previous part of this section. However, natural resources assessement receives abundant attention from the public and from the NRC staff as indicated by NRC SCA Comment \#53, so the activities which will furnish geophysical data for assessment of resource potential should be given schedule priority. The methods that have been identified for possible use in resource assessment are surface resistivity, induced polarization (IP), gravity, aeromagnetics and ground magnetics, seismic reflection and refraction, and magnetotellurics. (These have already been identified as high priority activities in conjunction with studies of subsurface structure for the tectonic model.) A key information need for resource assessment that will be addressed using the methods identified is the geometry of the Paleozoic-Tertiary contact. The applicable geophysical surveys are organized under SCP Study 8.3.1.17.4.7, but supporting activities should also include planned peer reviews (see above) and the program of feasibility testing and scoping analyses (see section 3.3 of this report).

\section{Feasibility Test Plan - Geophysics Integration and Feasibility Testing}

It is recommended that a test plan be prepared to provide necessary documentation and basis for approval of a planned program of geophysical feasibility and scoping analyses. The limited scope of the feasibility testing program, limited impact of the activities on the site, and the objectives for feasibility testing, should permit relatively straightforward technical review and approval of the plan. Organizing the various feasibility tests under a single plan should also help to expedite review and approval, and is appropriate to ensure timely implementation of the tests. 
The activity priorities discussed above are summarized in Table 3.2-2, which identifies hj.gh priority activities, actions that need to be taken, when, and by whom. Some of these actions do not require study Plans, some are covered under existing Study Plans as indicated, and some are feasibility tests as discussed in the following section. 
Table 3.2-2 Summary of High-Priority Geophysical Activities (page 1 of 2)

\begin{tabular}{|c|c|c|c|c|}
\hline Action & $\begin{array}{l}\text { Timing and } \\
\text { Prerequi- } \\
\text { sites }\end{array}$ & Responsibility & $\begin{array}{l}\text { Study Plan } \\
\text { 8.3.1.X.X.X }\end{array}$ & $\begin{array}{l}\text { Prioritization } \\
\text { Concern }\end{array}$ \\
\hline $\begin{array}{l}\text { A. (1) Peer Review Notice, for review } \\
\text { of the applicability of regional } \\
\text { geophysical traverses to site } \\
\text { characterization } \\
\text { (2) Peer review (SCP Activity } \\
8.3 .1 .17 .4 .3 .1 \text { ) }\end{array}$ & $\begin{array}{l}\text { ASAP, per } \\
\text { QMP-03-01 } \\
\\
\text { Approval } \\
\text { of Peer } \\
\text { Review } \\
\text { Plan }\end{array}$ & $\begin{array}{l}\text { Project Office } \\
\text { Project Office to } \\
\text { initiate and sup- } \\
\text { port; USGS partici- } \\
\text { pation in review } \\
\text { functions }\end{array}$ & $N / A$ & $\begin{array}{l}\text { Applicatility of } \\
\text { regional gephysical } \\
\text { traverses such as those } \\
\text { identified in SCP } \\
\text { Activity } 8.3 .1 .17 .4 .3 .1\end{array}$ \\
\hline $\begin{array}{l}\text { B. (1) Peer Review Notice, for } \\
\text { review of Seismic Methods for } \\
\text { Characterizing Yucca Mountain } \\
\text { and Vicinity } \\
\text { (2) Peer review (SCP Activity } \\
8.3 .1 .17 .4 .7 .1 \text { ) }\end{array}$ & $\begin{array}{l}\text { ASAP, per } \\
\text { QMP-03-01 } \\
\\
\text { Approval } \\
\text { of Peer } \\
\text { Review } \\
\text { Plan }\end{array}$ & $\begin{array}{l}\text { Project Office } \\
\text { Project Office to } \\
\text { initiate and sup- } \\
\text { port; USGS partici- } \\
\text { pation in review } \\
\text { functions }\end{array}$ & $N / A$ & $\begin{array}{l}\text { Successful seismic } \\
\text { reflection methodology; } \\
\text { structural profile across } \\
\text { YM, Crater Flat, and } \\
\text { Jackass Flat; characterize } \\
\text { volcanic deposits in } \\
\text { Amargosa Desent }\end{array}$ \\
\hline $\begin{array}{l}\text { C. VSP feasibility test (Activity } \\
8.3 \cdot 1.4 \cdot 2.2 .5 \text { ) }\end{array}$ & $\begin{array}{l}\text { ASAP } \\
\text { (Site } \\
\text { access) }\end{array}$ & USGS (LBL) & N/A & $\begin{array}{l}\text { Application io seismic } \\
\text { reflection methodology; } \\
\text { fracture/fault char. in } \\
\text { repository block; plan } \\
\text { ESF VSP; plan VSP in } \\
\text { surface boreholes. }\end{array}$ \\
\hline $\begin{array}{l}\text { D. Seismic refraction line } \\
\text { (Activity } 8.3 .1 .4 .2 .1 .2 \text { ) }\end{array}$ & $\begin{array}{l}\text { Peer } \\
\text { Review of } \\
\text { Seismic } \\
\text { Methods }\end{array}$ & USGS & $N / A$ & $\begin{array}{l}\text { Structure of northern } \\
\text { YM; structural cause for } \\
\text { large hydraulic gradient. }\end{array}$ \\
\hline $\begin{array}{l}\text { E. Teleseismic data collection } \\
\text { and inversion (associated with } \\
\text { SCP Activities 8.3.1.8.1.1.3 and } \\
\text { 8.3.1.17.4.1.2) }\end{array}$ & $\begin{array}{l}\text { Study } \\
\text { Plan } \\
8.3 \cdot 1 \cdot 8 \cdot 1.1 \\
\text { and } \\
8.3 \cdot 1 \cdot 17 \cdot 4 \cdot 1\end{array}$ & USGS & TBD & $\begin{array}{l}\text { Structural reconnais- } \\
\text { saince; correlate mid- } \\
\text { and lower crust features } \\
\text { with surface structure } \\
\text { incl. volcanic deposits. }\end{array}$ \\
\hline $\begin{array}{l}\text { F. Geoelectric data interpretation and } \\
\text { scoping analyses. }\end{array}$ & $\begin{array}{l}\text { Feasibility } \\
\text { test plan }\end{array}$ & USGS & N/A & $\begin{array}{l}\text { Applicability of existing } \\
\text { data and available } \\
\text { techniques to investi- } \\
\text { yation of large hydraulic } \\
\text { gradient area; natural } \\
\text { resource assessment. }\end{array}$ \\
\hline
\end{tabular}


Table 3.2-2 Summary of High-Priority Geophysical Activities (page 2 of 2)

\begin{tabular}{|c|c|c|c|c|}
\hline Action & $\begin{array}{l}\text { Timing and } \\
\text { Prerequi- } \\
\text { sites }\end{array}$ & Responsibility & $\begin{array}{l}\text { Study Plan } \\
\text { 8.3.1.X.X.X }\end{array}$ & $\begin{array}{l}\text { Prioritization } \\
\text { Concern }\end{array}$ \\
\hline $\begin{array}{l}\text { G. Feasibility test for detection and } \\
\text { delineation of volcanic deposits by } \\
\text { geophysical methods. }\end{array}$ & $\begin{array}{l}\text { Feasibility } \\
\text { test plan }\end{array}$ & $\begin{array}{l}\text { USGS, with input } \\
\text { from LANL }\end{array}$ & N/A & $\begin{array}{l}\text { Volcanic hazard } \\
\text { assessment. }\end{array}$ \\
\hline $\begin{array}{l}H . \text { Feasibility test of borehole and } \\
\text { related methods for fracture/fault } \\
\text { zone characterization in the } U Z \\
\text { and } S Z \text {. }\end{array}$ & $\begin{array}{l}\text { Feasibility } \\
\text { iest plan }\end{array}$ & USGS & $N / A$ & $\begin{array}{l}\text { Resolve applicability of } \\
\text { geophysics to charac- } \\
\text { terization of the repo- } \\
\text { sitory block; require- } \\
\text { ments on boreholes } \\
\text { penetrating the block. }\end{array}$ \\
\hline $\begin{array}{l}\text { I. Detailed aeromagnetic survey } \\
\text { (Activity } 8.3 .1 .17 .4 .7 .4 \text { ) }\end{array}$ & $\begin{array}{l}\text { Study Plan } \\
8.3 .1 .17 .- \\
4.7 ; \\
\text { feasibility } \\
\text { testing }\end{array}$ & $\begin{array}{l}\text { USGS, input from } \\
\text { LANL }\end{array}$ & .17 .4 .7 & $\begin{array}{l}\text { Distribution of volcanic } \\
\text { deposits; reconnais- } \\
\text { sance of large hydraulic } \\
\text { gradient area; mineral } \\
\text { resource assessment; } \\
\text { detailed Curie isotherm } \\
\text { analysis. }\end{array}$ \\
\hline $\begin{array}{l}\text { J. Feasibility lest of the use of MT } \\
\text { traverses for exploration of the } \\
\text { large hydraulic gradient area }\end{array}$ & $\begin{array}{l}\text { Feasibility } \\
\text { test plan }\end{array}$ & 'USGS & $N / A$ & $\begin{array}{l}\text { Structure of northern } \\
\text { Yucca Mountain, as a } \\
\text { possible cause for the } \\
\text { large hydraulic gradient. }\end{array}$ \\
\hline $\begin{array}{l}\text { K. Feasibiiity test of seismic reflection } \\
\text { for structural profiling across Yucca } \\
\text { Mountain and vicinity. }\end{array}$ & $\begin{array}{l}\text { VSP test; } \\
\text { Peer } \\
\text { Review of } \\
\text { Seismic } \\
\text { Methods; } \\
\text { Feasibiiity } \\
\text { test plan }\end{array}$ & USGS & N/A & $\begin{array}{l}\text { Demonstrate applica- } \\
\text { bility of seismic reflection } \\
\text { for site characterization; } \\
\text { structural profile across } \\
\text { Yucca Mountain, Crater } \\
\text { Flat, and part of Jackass } \\
\text { Flat. }\end{array}$ \\
\hline $\begin{array}{l}\text { L. Feasibility test of the Mini-Sosie } \\
\text { method for fault detection and } \\
\text { characterization in the vicinity of } \\
\text { Yucca Mountain. }\end{array}$ & $\begin{array}{l}\text { Feasibility } \\
\text { test plan }\end{array}$ & USGS & $N / A$ & $\begin{array}{l}\text { Determine extent to } \\
\text { which method can be } \\
\text { relied upon in site } \\
\text { characterization. }\end{array}$ \\
\hline $\begin{array}{l}\text { M. Preparation and review of plan for } \\
\text { geophysics integration and } \\
\text { feasibility testing, corresponding to } \\
\text { SCP Section 8.3.1.4.1.2. }\end{array}$ & TBD & TBD & $N / A$ & $\begin{array}{l}\text { Structure the integration } \\
\text { activity; produce a single } \\
\text { integrated geophysical } \\
\text { feasibility test plan to } \\
\text { facilitate review, } \\
\text { approval, and implemen- } \\
\text { tation. }\end{array}$ \\
\hline
\end{tabular}




\subsection{FEASIBILITY TESTS}

Testing is needed to establish whether and how certain geophysical methods will work at Yucca Mountain, beiore the Project makes significant commitments to these methods (or to alternatives) in terms of budget or schedule. Successful geophysical exploration typically depends on adapting instrumentation, field procedures, and interpretive methods to a particular geologic setting. Useful results have already been obtained from several geophysical activities as discussed in section 3.1 and summarized in section 4.0. However, some important methods for exploring the Yucca Mountain site are developmental. Notably, although some surveys have failed in the past, it is too soon to abandon such powerful techniques as seismic reflection. An immediate program is needed to prove these techniques, and it would be best to conduct a portion of this effort as a timely program of feasibility testing.

The geophysical feasibility testing program is recommended by this report as an addition to the site characterization program. The nature of the recommended program would be similar to that of prototype testing in G-tunnel on the NTS, but geophysical tests would be performed at or near Yucca Mountain. If the recommended feasibility testing program is implemented, a scientific test plan would first undergo technical review and approval in accordance with project procedures.

It is recormended that the planning basis for feasibility testing be a Geophysical Feasibility Testing Plan. The plan will include evaluation of the potential adverse impacts on site performance from feasibility testing activities, and the potential for interference with other ongoing or future data collection activities.

A list of proposed feasibility tests is presented in Table 3.3-1. Although many of the methods to be tested are mentioned in SCP Sections 8.3.1.2, 8.3.1.4, and 8.3.1.17, feasibility tests are not identified in the SCP except for the VSP feasibility test (8.3.1.4.2.2.5) and Mini-Sosie feasibility test (8.3.1.17.4.7.8). Integration of geophysical activities is best served by consolidating the needed feasibility tests into a single plan. Approval for needed tests will be expedited because the activities are similar and can be evaluated together with respect to potential adverse impacts, test int irference, site access, and environmental clearances.

The feasibility tests are mostly independent of one another, and represent little potential for adverse impacts or interference with other activities. They should be conducted as soon as practicable to be effective. Commencement of feasibility testing will be contingent on approval of the Geophysical Feasibility Testing Plan and compietion of related requirements such as technical procedures.

In conjunction with feasibility testing, scoping analyses will be performed as indicated in Table 3.3-1. These may include some calculations, and are needed to evaluate characterization concepts not considered explicitly in the SCP, and to translate results from feasibility testing into specific plans for site characterization. An important scoping analysis will be to evaluate the need for long-term geophysical monitoring, to include 
construction of a geophysical observatory at Yucca Mountain. Scoping analyses will be further defined in the feasibility testing plan. 


\begin{tabular}{|c|c|c|}
\hline Item & Description & $\begin{array}{l}\text { Related SCP } \\
\text { Studies/Activities }\end{array}$ \\
\hline FEASIBILITY & TESTS TO BE VESGRIBED IN STUDY PLAN 8. & .3 .1 .4 .1 .2 \\
\hline 1. IP logs & $\begin{array}{l}\text { Evaluate IP logs and core data as } \\
\text { an indivator of alteration, and } \\
\text { acquire new IP logs from one or } \\
\text { two existing uncased boreholes. }\end{array}$ & 8.3 .1 .4 .2 .1 .3 \\
\hline $\begin{array}{l}\text { 2. Radioactivity } \\
\text { methods }\end{array}$ & $\begin{array}{l}\text { Ground radioactivity profiles will } \\
\text { be run across known faults and } \\
\text { other features, to evaluate the } \\
\text { method for fault detection and the } \\
\text { feasibility of airborne surveys for } \\
\text { fault detection. }\end{array}$ & 8.3 .1 .17 .4 .7 .6 \\
\hline $\begin{array}{l}\text { 3. Infrared } \\
\text { remote sensing }\end{array}$ & $\begin{array}{l}\text { Preliminary testing of airborne } \\
\text { and satellite infrared sensing } \\
\text { methods for investigating } \\
\text { infiltration processes in surficial } \\
\text { materials. }\end{array}$ & 8.3 .1 .17 .4 .7 .7 \\
\hline $\begin{array}{l}\text { 4. Detailed } \\
\text { magnetic } \\
\text { profiles }\end{array}$ & $\begin{array}{l}\text { Truck-magnetometer profiles will } \\
\text { be run along existing roads } \\
\text { crossing known faults to evaluate } \\
\text { the usefulness of the method for } \\
\text { fault detection. }\end{array}$ & 8.3 .1 .17 .4 .7 .4 \\
\hline $\begin{array}{l}\text { 5. Calibration } \\
\text { boreholes }\end{array}$ & $\begin{array}{l}\text { Investigate the feasibility of } \\
\text { calibrating borehole nuclear } \\
\text { logging methods for the UZ by } \\
\text { means of shallow calibration } \\
\text { boreholes. }\end{array}$ & $\begin{array}{l}8.3 \cdot 1 \cdot 2 \cdot 2 \cdot 1 \cdot 1 \\
8.3 \cdot 1 \cdot 4.2 .1 .3\end{array}$ \\
\hline $\begin{array}{l}\text { 6. Logging methods } \\
\text { for UZ studies }\end{array}$ & $\begin{array}{l}\text { Acquire and analyze a limited } \\
\text { number of logs, including dielectric, } \\
\text { nuclear magnetic resonance, and } \\
\text { high-resistivity induction, for } \\
\text { reliable estimation of water content } \\
\text { in the UZ. }\end{array}$ & $8 \cdot 3 \cdot 1 \cdot 2 \cdot 2 \cdot 3 \cdot 2$ \\
\hline $\begin{array}{l}\text { 7. Geoelectric } \\
\text { data analysis }\end{array}$ & $\begin{array}{l}\text { Analyze and reinterpret existing } \\
\text { data, to support the planned review } \\
\text { of the applicability of geoelectric } \\
\text { methods for fault detection, charac- } \\
\text { terizing the large hydraulic gradient } \\
\text { area, and lithology variation in } \\
\text { bedrock. }\end{array}$ & $8.3 .1 .17 \cdot 4.7 .5$ \\
\hline
\end{tabular}


Table 3.3-1. Geophysical Feasibility Tests (continued)

\begin{tabular}{|c|c|c|c|}
\hline Item & & Description & $\begin{array}{l}\text { Related SCP } \\
\text { Studies/Activities }\end{array}$ \\
\hline 8. & $\begin{array}{l}\text { Detailed } \\
\text { gravity and } \\
\text { magnetic methods }\end{array}$ & $\begin{array}{l}\text { Obtain new detailed data and } \\
\text { profiles to test methods for } \\
\text { detecting concealed faults, } \\
\text { and for investigating the large } \\
\text { hydraulic gradient in the site area }\end{array}$ & 8.3 .1 .17 .4 .7 .2 \\
\hline 9. & $\begin{array}{l}\text { Geophysical } \\
\text { monitoring } \\
\text { scoping } \\
\text { analysis }\end{array}$ & $\begin{array}{l}\text { Evaluate needs, applicable methods, } \\
\text { and potential costs for geophysical } \\
\text { monitoring activities to begin during } \\
\text { site characterization. Methods to be } \\
\text { considered include continuous nano } \\
\text { gravity monitoring, micro-seismic } \\
\text { monitoring of the repository block, } \\
\text { magnetic field monitoring, strain and } \\
\text { tilt measurements, and construction } \\
\text { of a geophysical observatory. }\end{array}$ & $\begin{array}{l}8.3 .1 .17 .4 .7 \\
8.3 .1 .8 .5 .1\end{array}$ \\
\hline & $\begin{array}{l}\text { Test of seismic } \\
\text { reflection at } \\
\text { Yucca Mountain }\end{array}$ & $\begin{array}{l}\text { Seismic line across Crater Flat, } \\
\text { Yucca Mountain, and Midway Valley. } \\
\text { Primary objective to evaluate } \\
\text { conventional seismic profiling } \\
\text { methods for imaging the first } \\
5 \text { sec at and near Yucca Mountain. } \\
\text { Depends on the outcome of the Peer } \\
\text { Review of Seismic Methods (SCP } \\
\text { Activity } 8.3 .1 .17 .4 .7 .1 \text { ), and the VSP } \\
\text { feasibility test (see above). }\end{array}$ & $\begin{array}{l}8.3 .1 .17 .4 .3 .1 \\
8.3 .1 .17 .4 .7 .1\end{array}$ \\
\hline & $\begin{array}{l}\mathrm{MT} \text { and } \mathrm{AMT} \\
\text { traverses across } \\
\text { large hydraulic } \\
\text { gradient area }\end{array}$ & $\begin{array}{l}\text { Evaluate MT methods for recon- } \\
\text { naissance and characterization of } \\
\text { specific features of the large } \\
\text { hydraulic gradient area. Acquire a } \\
\text { limited program of } 10 \text { stations along } \\
\text { traverses perpendicular to the } \\
\text { strike of the gradient inferred from } \\
\text { boreholes. Slpport evaluation of } \\
\text { geoelectric methods for SCP Activity } \\
8.3 .1 .17 .4 .7 .5 \text {. }\end{array}$ & $8.3 \cdot 1.2 .3 \cdot 1.2$ \\
\hline 12. & $\begin{array}{l}\text { Feasibility test } \\
\text { of borehole } \\
\text { methods for } \\
\text { characterizirg } \\
\text { fracturing and } \\
\text { fault zones in } \\
\text { the Uz and Sz }\end{array}$ & $\begin{array}{l}\text { Evaluate large-spacing ER and EM } \\
\text { logs, for tracing the extent of } \\
\text { features observed in boreholes. } \\
\text { Extend methods to surface-to- } \\
\text { borehole geometry as appropriate. } \\
\text { Evaluate hydrophone VSE and } \\
\text { heat-pulse flowmeter technology } \\
\text { for sz fracture characterization. }\end{array}$ & $\begin{array}{l}8 \cdot 3 \cdot 1 \cdot 2 \cdot 2 \cdot 3 \\
8 \cdot 3 \cdot 1 \cdot 2 \cdot 3 \cdot 1 \\
8 \cdot 3 \cdot 1 \cdot 4 \cdot 2 \cdot 1 \cdot 3 \\
8 \cdot 3 \cdot 1 \cdot 4 \cdot 2 \cdot 2 \cdot 3\end{array}$ \\
\hline
\end{tabular}


Table 3.3-1. Geophysical Feasibility Tests (continued)

Description

Related SCP

Studies/Activities

13. Test of gravity and ground magnetic methods for volcanism studies
14. Test of teleseismic tomography for detecting partial melt beneath Crater Flat

15. Test of shallow high-resolution seismic reflection techniques (i.e., MiniSosie or other systems) in support of. paleoclimate studies
Investigate a feature or features likely to provide sufficient information to evaluate the approach. Collect and analyze samples; investigate the relation of ground magnetics to existing aeromag. data. Explore for indication of feeder dikes. Perform scoping analyses to evaluate uncertainty in material properties and deposit geometry.

Test intermediate-period seismometers in the unconsolidated surface material of Crater Flat, for the purpose of recording compressional and shear wave arrivals, measuring attenuation, and measuring $\mathrm{P}$-wave receiver response functions.

Acquire profiles across marsh, lacustrine, playa, and volcanic sequences at various locations throughout the Southern Great Basin.
8.3 .1 .8 .5 .1

8.3 .1 .17 .4 .7
$8 \cdot 3 \cdot 1 \cdot 8 \cdot 1 \cdot 1.3$

8.3 .1 .17 .4 .1 .2

FEASIBILITY TESTS DESCRIBED BY EXISTING PROGRAM DOCUMENTS

16. VSP feasibility test
Investigate the use of VSP to map subsurface fracturing and other features in the vicinity of boreholes. Testing is needed to (a) define the methodology and the UZ seismic response, (b) support planning certain characterization activities, and (c) constrain activity descriptions for impacts analysis and evaluation of test interference. (SCP Activity $8.3 .1 .4 .2 .2 .5)$
$8.3 \cdot 1.2 .2 .3 .2$

\author{
$8 \cdot 3 \cdot 1 \cdot 5 \cdot 1 \cdot 2 \cdot 2$ \\ 8.3 .1 .17 .4 .3 \\ 8.3 .1 .17 .4 .7
}


Table 3.3-1. Geophysical Feasibility Tests (continued)

\begin{tabular}{|c|c|c|}
\hline Item & Description & $\begin{array}{l}\text { Related SCP } \\
\text { Studies/Activities }\end{array}$ \\
\hline $\begin{array}{l}\text { 17. Feasibility } \\
\text { Test of the } \\
\text { Mini-sosie } \\
\text { seismic re- } \\
\text { flection } \\
\text { method for } \\
\text { fault detec- } \\
\text { tion and } \\
\text { characteri- } \\
\text { zation }\end{array}$ & $\begin{array}{l}\text { Evaluate application of Mini-sosie } \\
\text { method at or proximal to the site } \\
\text { area. Acquire two preliminary } \\
\text { traverses, to be used as the basis } \\
\text { for deciding to proceed with seven } \\
\text { or more additional profiles, or to } \\
\text { apply the method more selectively. }\end{array}$ & 8.3 .1 .17 .4 .7 .8 \\
\hline
\end{tabular}




\subsection{QA REQUIREMENTS FOR USING DATA FROM PAST GEOPHYSICAL ACTIVITIES}

\section{INTRODUCTION}

Geophysical data are likely to be used as primary and secondary input for calculations and modeling activities to assess compliance with regulatory objectives. The DOE must be able to demonstrate in a license application that the applicable requirements of 10 CFR Part 60 have been fulfilled. Existing geophysical data and data analyses which have not been performed under a quality assurance (QA) program that meets the requirements of $10 \mathrm{CFR}$ 60 , Subpart $G$, but which will support the DOE's license application to construct and operate a geologic repository, will be qualified. This includes qualification of existing data that were collected under a $Q A$ program that did not meet Subpart $G$ requirements. This section briefly describes steps that will be taken to assess whether existing geophysical data can be used in licensing.

Specific requirements for qualifying data are provided in the Yucca Mountain Project QA Plan (NNWSI 88-9, Appendix G), which is consistent with NRC guidance entitled: Qualification of Existing Data for High Level Nuclear Repositories (NUREG-1298). Many of the specific requirements are implemented in Yucca Mountain Project administrative procedure AP5.9Q (Qualification of Data or Data Analyses not Developed Under the Yucca Mountain Project Quality Assurance Plan)

If existing geophysical data are identified as primary information that will be, or may be, used in support of licensing, the data may then be submitted to the qualification process defined by AP5.92. Existing data may already meet $Q A$ requirements if initially developed under a $Q A$ program; however, this must be demonstrated through the qualification process. As described in AP5.92, possible outcomes of the qualification process include recommendations that the data be qualified in whole or in part, or that further actions such as confirmatory testing or peer review be undertaken prior to qualification.

The QA program for site exploration has evolved from 1977 to present and has incorporated requirements in effect at the time work was performed. The QA program has been modified as new requirements were imposed, or adopted by the DOE. A QA program that meets 10 . CFR 60, subpart $G$, will be in place prior to the start of planned geophysical activities for site characterization. However, $\nu y$ the current definition such a program was not in place for collection and aralysis of existing data. Therefore all existing data and data analyses are subject to qualification, as appropriate. Application of the qualification procedure (AP5.92) depends on whether the qualification criteria are met, and the necessary approvals are obtained.

This sction of the report contains a summary of the applicable requirements and a brief review of the qualification procedure. In addition, geophysical data sets considered likely to require qualification before licensing are identified, with a statement of rationale. Finally, one geophysical data set is identified as best suited for initial application of the qualification procedure AP5.92. The outcome of the initial effort will be used by the geophysics integration activity to determine the nature, priority, and appropriate scope for qualification of the other data sets. 
Note that existing geophysical data sets not specified below can also be qualified on an as-needed basis. This may include data developed prior to implementation of a 10 CFR 60, subpart G, QA program by the DOE and its contractors; data developed outside the DOE repository program by energy or mineral companies, geophysical service contractors, national laboratories, or universities; and data published in technical or scientific publications.

\section{NRC-DEFINED DATA QUALIFICATION METHODS}

The NRC has defined four acceptable alternative methods or combinations of methods in NUREG-1298. These methods are incorporated in NNWSI 88/9, Appendix $G$, and are implemented in AP5.9Q:

Method A. Peer Review of Data

A peer review will be a documented, critical review performed by two or more peers who are independent of the data or data analyses under review. Peer independence means that the peer (a) was not or is not involved as participant, supervisor, technical reviewer, or advisor in the work being reviewed; and (b) has sufficient freedom from funding considerations, employment, or business associations with program participants to ensure impartiality and to preclude the perception of conflict or vested interest.

Method B. Use of Corroborating Data

Existing data may be used to support or substantiate other existing data. Inferenct. drawn for corroboration must be clearly identified, justified, and documented. The level of confidence associated with corroboration is related to the quality of the program under which corroborating data were developed, and the number of independent data sets. The extent of corroborating data appropriate for qualification purposes should be determined and documented on a case-by-case basis.

Method C. Use of Confimatory Testing

Testing may be conducted under a 10 CFR 60, subpart 6 , CA program to reexamine the features of an existing data set. Such testing need not necessarily employ the same test method, provenance, or test conditions as the original work, but the applicability of confimatory testing must be justified and documented. One example of confirmatory testing could be testing conducted with different methods and equipment, but which investigates subsurface structure at the location interest. The extent of confirmatory testing appropriate for qualification purposes should be determined and documented on a case-by-case basis.

Method D. Demonstrate Consistent QA Program

Demonstrate that a $Q A$ program consistent with the Project QA Plan (NNWSI 88-9) was used during specific activities that produced the existing geophysical data or data analyses. 
Methods $B, C$, and $D$ should be accompanied by a documented technical review by two or more qualified independent reviewers, to determine the quality of the geophysical data or data analyses, and the merit of any inferences used for qualification. Additional confidence and/or credibility will be achieved when a combination of Methods $A$ through $D$ is used.

\section{THE QUALIFICATION RROCESS}

Planned application of the qualification process to geophysical data is described below in several steps:

1. Geophysical data for the Yucca Mountain site and region developed by the DOE and its contractors; or data developed outside the DOE repository program by energy or mineral companies, geophysical service contractors, national laboratories, or universities; or data published in technical or scientific publications, will be identified by Project Principal Investigators. This step is generally satisfied for existing geophysical data by Chapter 2 of this report, except for topical areas as noted in section 1.0 .

2. The geophysics integration activity (SCP Section 8.3.1.4.1.2) will review the existing data sets described in Chapter 2, and select for qualification any that are likely to be used for: characterizing natural barriers important to waste isolation, design of engineered structures important to waste isolation and/or preclosure radiological safety, or issue resolution in support of repository licensing. (The Amargosa Valley seismic reflection test line is identified below as the best candidate data set for the initial application of the qualification process to geophysical data.)

3. The geophysics integration activity will submit a Qualification Request to the Yucca Mountain Project office, recommending application of one or more of the qualification methods described above to the selected data. The rationale for selection of data sets will be documented, including the reason why the data collection or analyses cannot be repeated, and an assessment of the existing data with respect to the qualification methods and attributes listed in procedure AP5.92.

4. The Qualification Request will be reviewed by the Director, Regulatory and Site Evaluation Division, Yucca Mountain Project Office, or designee in accordance with AP5.9Q. If the request is approved, a technical review or peer review, as appropriate, will be convened by the Director in accordance with the procedure. The outcome of the review will determine the status of data qualification. Documentation of the outcome, including all corroborating or confirmatory data, will become a QA record. 
A number of geophysical data sets are good candidates for use in licensing, but they differ with respect to the nature of data or data analyses for qualification. Two major, related discriminating factors are whether data processing contributed significantly to a product, and whether industry-standard commercial data collection or processing services were used.

Qualification of directly measured data is potentially more straightforward than review of data analyses. Reviewers will be required to consider measurement procedures, calibrations, record keeping, surveillance, environmental conditions, corroborating measurements, and confirmatory data, as appropriate. Examples of such data include most gravity and magnetic measurements, and survey or navigation control for these measurements. Other types of direct measurements may also be qualified, such as standard borehole geophysical logs, and ground motion recordings for seismic refraction surveys.

In general, geophysical data will be processed for use in licensing. Data are typically presented in processed maps and cross-sections. Geophysical models are presented as map or cross-section representations of earth structure. which require calcuiation of earth response. Data processing includes a wide range of corrections and enhancements varying in importance and complexity. For qualification of processed products, reviewers will be required to consider software $Q A$ where controls on the use of software could have a significant effect on quality. Examples of such products are terrain-corrected Bouguer gravity maps, composite aeromagnetic maps, seismic reflection sections, and velocity models from seismic refraction data.

In cases where industry-standard data collection or processing services have been performed by reputable geophysical contractors, there may have been proprietary or contractual restrictions on the implementation or verification of $Q A$. For qualifying products of this nature, reviewers will determine the specific $Q A$ requirements that have not been explicitly addressed, and determine whether the measures actually taken constitute reliable and effective quality control that can be demonstrated in licensing.

Regional gravity and aeromagnetic maps are candidates for qualification because they represent accumulated data relevant to establishing the regional context for geologic structure and other aspects of the Yucca Mountain site. By qualifying the regional maps, a substantial portion of the available data will be adiressed. Reacquisition of regional data would be prohibitive and unnecessary.

Potentially important gravity maps include Ponce et al. (1988), Kane et al. (1979), and Healey et al. (1980) from the reference list of Section 2.1 of this report. The reports of Snydez et al. (1981), Jansma et al. (1982), and Saltus (1988) contain principal facts for gravity stations in the Yucca Mountain region. Additional detailed gravity and magnetic data for the site area and vicinity will be collected during site characterization, and will confirm or supersede the existing regional data over a large area. Qualification of existing gravity measurements from the site area, such as 
the borehole gravity surveys of Healey (1986) and Healey et al. (1984), will be deferred at least until the detailed data are available. Similarly, qualification of gravity measurements from the monitoring program of Harris and Ponce (1988) and from the survey of zumberge et al. (1988) can be deferred until additional data are collected under the fully qualified $Q \mathrm{~A}$ program.

Several existing regional magnetic maps are candidates for qualification, including the 1:750,000 scale map of Hildenbrand and Kucks (1988), and the mosaic 1:250,000 sheets complete or in preparation (Saltus and Snyder, 1986; Saltus and Ponce, 1988). The 1:48,000 scale map of Kane and Bracken (1983) is also a good candidate because it covers a larger area than the planned detailed aeromagnetic survey (SCP Activity 8.3.1.17.4.7.4). Qualification of existing ground magnetic data from the site area and vicinity will be deferred at least until acquisition and analysis of the planned detailed aeromagnetic survey, and the planned feasibility test of gravity and ground magnetic methods for volcanism studies (see section 3.3). Similarly, qualification of paleomagnetic data will be deferred until additional, corroborating or confirmatory measurements have been made during site characterization.

High-resolution upper-crustal seismic refraction lines are good candidates for qualification for several reasons. Structural profiles interpreted from these data currently constitute one of the most extensive and reliable data sets for use in tectonic studies. Refraction lines have already been run across Yucca Mountain, along Fortymile Wash, through Crater Flat, and across the Ainargosa Desert, where seismic reflection lines are tentatively planned. Qualification of the ground motion recordings from these surveys (Sutton, 1984, 1985) will be straightforward, and qualification of processing (Ackerman et al.., in USGS, 1988) can readily be addressed independently from that of recorded data. In addition, the reconnaissance survey reported by Hoffman and Mooney (1983), which used UNE sources and one high-explosive shot, will be examined. There appears to be no reason for qualifying the refraction data reported by Pankratz (1982), at least until corroborating detailed gravity and seismic reflection data are available, and until reinterpretation of the original refraction data has been performed using all available borehole control and velocity data.

Existing seismic reflection data are of little use for site characterization, except for the Amargosa Valley test line (Brocher et al., 1989), as discussed in section 2.5 of this report. The test line was acquired recently, with systematic quality control, and is the best candidate for the first geophysical data set to be qualified under procedure AP5.9Q. The line will probably eventually be used to tie other reflection lines that are tentatively planned for the site area. The data set is a good choice because industry-standard data collection and processing services were provided by a geophysical contractor. The review will help to establish the basis for qualifying other existing data that have been collected or processed using industry-standard practices.

Borehole geophysical logs are a candidate data set for qualification, principally because many existing boreholes in the immediate vicinity of the site have been completed so that they can no longer be logged. These logs will probably be important in assessing lateral variability of rock 
characteristics or hydrologic conditions in the site area. Even for boreholes that can be reentered, relogging is not generally a viable alternative for moisture sensitive logs in the UZ. This is because uncased or uncemented boreholes are subject to drying and moisture movement associated with gas circulation. Efforts are currently underway to assemble, correct, replot, and analyze the existing borehole logs. A qualification request can be formulated when documentation of these efforts is complete.

In summary, the seismic reflection test line of Brocher et al. (1989) is the best candidate for the first set to be submitted for qualification review. The necessary documentation of the data set is available, and the $Q A$ status of the activity is amenable to qualification of the data set for use in licensing. Preparation of a qualification request for review of the Amargosa Valley reflection test line is identified as a high-priority activity for geophysical integration in Section 3.2 of this report. Among the other data sets identified, the regional maps of potential field variation, the existing seismic refraction data, and the borehole geophysical logs are good candidates for future qualification review.

\section{REFERENCES}

Ackermann, H.D., W.D. Mooney, D.B. Snyder, and V.D. Sutton, 1988. "Preliminary Interpretation of Seismic Refraction and Gravity Studies West of Yucca Mountain, Nevada and California," in Carr, M.D., and J.C. Yount (eds.), Short Contributions to the Geology and Hydrology of a Potential Nuclear Waste Site at Yucca Moluntain, Southern Nevada, U.S. Geological Survey Bulletin 1790, pp. 23-33.

Brocher, T.M., P.E. Hart, and S.F. Carle, 1989. Feasibility Study of the Seismic Reflection Method in Amargosa Desert, Nye County, Nevada, U.S. Geological Survey Open File Report, in preparation.

DOE (U.S. Department of Energy), 1989. Technical Planning Basis: Site Characterization, Yucca Mountain Site, Nevada Research and Development Area, YMP/CC-0005, U.S. DOE, Las Vegas, Nevada.

Harris, R.N. and D.A. Ponce, 1988. High-Precision Gravity Network to Monitor Temporal Variations in Gravity Across Yucca Mountain, Nevada, U.S. Geological Survey Open File Report 88-243, 19 p. (in press).

Healey, D.I., 1986. Borehole Gravity Meter Survey in Drillhole USW G-4, Yucca Mountain Area, Nye County, Nevada, U.S. Geological Survey Open File Report 86-205, 18 pp.

Healey, D.I., F.G. Clustom, and D.A. Glover, 1984. Borehole Gravity Meter Surveys in Driliholes USW G-3, UE-25 p\#1, Yucca Mountain Area, Nevada, U.S. Geological Survey Open File Report 84-672, 16 pp.

Healey, D.L., R.R. Wahl, and H.W. Oliver, 1980. "Bouguer Gravity Map of Nevada, Death Valley Sheet," Nevada Bureau of Mines and Geology Map 69, scale $1: 250,000$. 
Hildenbrand, T.G., and R.P. Kucks, 1988. "Total Intensity Magnetic Anomaly Map of Nevada," Nevada Bureau of Mines and Geology Map 93A, scale $1: 750,000$.

Jansma, P.E., D.B. Snyder, and D.A. Ponce, 1982. Principal Facts $q$ fravity Stations with Gravity and Magnetic Frofiles from the Southwest $\mathbb{N}$ vada Test Site, Nye County, Nevada as of January, 1982, U.S. Geological Survey Open File Report 82-1041.

Kane, M.F., D.L. Healey, D.L. Peterson, H.E. Kaufmann, and D. Reidy, 1979. "Bouguer Gravity Map of Nevada, Las Vegas Sheet," Nevada Bureau of Mines and Geology Map 61, scale 1:250,000.

Kane, M.F., and R.E. Bracken, 1983. "Aeromagnetic Map of Yucca Mountain and Surrounding Regions, Southwest Nevada," U.S. Geological Survey Open File Report 83-616, scale 1:48,000.

Hoffman, L.R., and W.D. Mooney, 1983. A Seismic Study of Yucca Mountain and Vicinity, Southern Nevada: Data Report and Preliminary Results, U.S. Geological Survey Open File Report 83-588, 50 p., 1 plate.

Pankratz, L.W., 1982. Reconnaissance Seismic Refraction Studies of Calico Hills, Wahmonie, and Yucca Mountain, Southwest Nevada Test Site, Nye County, Nevada, U.S. Geological Survey Open File Report 82-478, 25 p.

Ponce, D.A., R.N. Harris, and H.W. Oliver, 1988. "Isostatic Gravity Map of the Nevada Test Site and Vicinity, Nevada," U.S. Geological Survey Open File Report 88-664, scale 1:100,000 (in press).

Saltus, R.W., 1988. Gravity Data for the State of Nevada on Magnetic Tape, U.S. Geological Survey Open File Report 88-433, 20 p.

Saltus, R.W., and D.B. Snyder, 1986. "Aeromagnetic Map of Nevada, Caliente Sheet," Nevada Bureau of Mines and Geology Map 89, scale 1:250,000; includes merged aeromagnetic map, scale $1: 1,000,000$.

Saltus, R.W., and D.A. Ponce, 1988. "Aeromagnetic Map of Nevada, Las Vegas Sheet," Nevada Bureau of Mines and Geology Map 95, scale 1:250,000; includes merged aeromagnetic map, scale $1: 1,000,000$.

SNL (Sandia National Laboratories), 1987. Site Characterization Plan--Conceptual Design Report, SAND84-2641, Albuquerque, New Mexico.

Snyder, D.B., C.W. Roberts, R.W. Saltus, and R.F. Sikora, 1981. Magnetic Tape Containing the Principal Facts of 64,402 Gravity Stations in the State of California, U.S. Geological Survey Report, 30 p.; available from National Technical Information Service, U.S. Department of Commerce, Springfield, VA 22161, NTIS PB-82168287.

Sutton, V.D., 1984. Data Report for the 1983 Seismic Refraction Experiment at Yucca Mountain, Beatty, and Vicinity, Southwestern Nevada, U.S. Geological Survey Open File Report 84-661, 66 p., 11 plates. 
Sutton, V.D., 1985. Data Report for the 1985 Seismic Refraction Experiment at Yucca Mountain, Beatty, and Vicinity, Southwestern Nevada, U.S. Geological Survey Open File Report 85-591, 96 p., 17 plates.

Zumberge, M.A., R.N. Harris, H.W. Oliver, G.S. Sasagawa and D.A. Ponce, 1988. Preliminary Results of Absolute and High-Precision Gravity Measurements at the Nevada Test Sice and Vicinity, Nevada, U.S. Geological Survey Open File Report 88-242, 29 F. 


\subsection{SUMMARY AND CONCLUSIONS}

The Yucca Mountain site is structurally complex, and has other aspects that complicate geophysical exploration, such as rugged topography and low seismic velocity near the surface. Because of these conditions and limitations on the scope of past activities, several important questions of hydrologic and tectonic significance have not been addressed by geophysicists. However, major results have been obtained and will be used as the basis for planned site characterization activities. (It is very likely that some existing data will be used for licensing, but specific data must be identified and qualified through the process described in section 3.4, and cannot be definitely identified at present.)

Major results include crustal exploration using gravity and seismic refraction, which have provided information on the thickness of tuffs at Crater Flat, and depth to the Paleozioc-Tertiary contact associated with major features of the site (see Section 2.4). Buried volcanics have been discovered by magnetic surveys in the vicinity of the site and in the Amargosa Desert (Section 2.2). Intermediate-depth seismic refraction has been demonstrated at the site, and the use of shallow seismic methods to characterize faults has also been demonstrated (Sections 2.4 and 2.5). Geoelectric methods have been used in the Yucca Mountain region and site area for vertical sounding and profiling applications, with preliminary results that will be evaluated during site characterization (Section 2.3).

Major problems were encountered with high-resolution seismic reflection along the eastern flank of Yucca Mountain (Section 2.5). Definitive analysis of these results will require additional field work, so the SCP contains plans to review the past work and identify an approach for future surveys.

Other geophysical methods have become generally available since the previous work was performed, such as vertical seismic profiling (VSP), methods for surface seismic data acquisition and processing, and thermal infrared imaging. Because the success of these new methods will depend on site-specific factors that have not yet been fully assessed, the SCP contains plans to review the available capabilities, perform feasibility testing, and apply them to site characterization as appropriate.

Plans in the SCP call for gravity, magnetics, and refraction surveys with increased coverage and resolution relative to existing data. At the same time, feasibility testing and technical review are planned to assess methods for detailed shallow and intermediate-depth investigation. Reviews of seismic and geoelectric methods will assess past results, and produce recommendations for using these methods to augment gravity, magnetics, and seismic refraction. Additional feasibility testing may be recommended by these reviews, and is already planned to evaluate the Mini-Sosie method, VSP, various gravity and magnetics applications, and radiometric methods (see Section 3.3).

Feasibility studies in addition to those planned in the SCP, possibly leading to new characterization activities, have been identified in this report and will be considered by the geophysics integration activity. Changes to the SCP program that are generated by the integration activity will be subject to review and approval in accordance with extant procedures 
for controlling the SCP progress reports, Study Plans, and the Project technical baseline.

Contrasts in seismic velocity, density, electrical resistivity, and magnetic properties are needed to observe geophysical structure. The Paleozoic-Tertiary contact is marked by a contrast in density, magnetization, and possibly seismic properties. Much of the structure of interest lies within the Tertiary section, where the density, magnetic, seismic, and electrical properties of welded tuff contrast with nonwelded tuff. However, contrast can be muted even at major interfaces such as the alluvium-tuff, welded-nonwelded tuff, and Paleozoic-Tertiary contacts, where there may have been weathering or alteration such that the variation in geophysical properties is gradational.

Because of site-specific factors and the problems encountered with seismic reflection at the site, it is presently expected that each geophysical method will produce only a partial geophysical model. An integrated approach is therefore planned for major objectives including investigation of the large hydraulic gradient, characterization of the repository block, detection and delineation of faults, and structural profiling across the site area.

Within the SCP framework, many different activities depend on geophysical data. Integration among activities is needed to ensure that maximum benefit is obtained from geophysical surveys and interpretations (see Section 3.2), and to ensure that the characterization program provides timely infornation appropriate to support a repository license application. 


\subsection{ACKNOWLEDGMENTS}

In addition to the editors, the following USGS earth scientists contributed to subsections in Section 2 shown in parentheses: D.A. Ponce and R.F. Sikora (gravity); J.G. Rosenbaum and D.E. Champion (magnetics); D.P. Klein and D. Hoover (electric); W.D. Mooney (seismic refraction); J.R. Evans (teleseismic); T.M. Brocher (seismic reflection); J. Friedman, M. Podwysocki, and J.A. Pitkin (remote sensing); and K. Glover and A. Flint (borehole geophysics). Section 3 on plans was pulled together largely by E. Hardin, and C. Fridrich of the Yucca Mountain Project Office. It is based on the Site Characterization Plan, but includes current information from available study plans by T.M. Brocher, J.R. Bergquist, S.F. Carle, W.E. Wilson, J. Rousseau, P. Sinton, J. Czarnecki, and others. This report has had the benefit of major reviews by R.J. Blakely, D.A. Ponce, D.V. Fitterman, T.G. Hildenbrand, B. Langer, and E.I. Majer. The maps for Sections 2 and 3 were produced by E. Ezra of EG\&G Energy Measurements Group/Las Vegas, with assistance from D. Brickey of EG\&G. 
APPENDIX A

Table of Contents for Volumes IV and V

of the Site Characterization Plan

(Section 8.0 to Section 8.3.1.17.5) 
DECEMBER 1988

TABLE OF CONTENTS

VOLUME IV

$\underline{\text { Page }}$

CHAPTER 8 SITE CHARACTERIZATION PROGRAM

8.0 Introduction . . . . . . . . . . . . . . . 8.0- 1

8.1 Rationale for the site characterization program . . . . . . 8.1- 1

8.1.1 The issues-based approach to planning site

characterization

$8.1-1$

8.1.1.1 Derivation, structure, and scope .......... .

8.1.1.2 Application in the site characterization plan. . .

8.1.2 Issue resolution strategy . . . . . . . . . . . . .

8.1.2.1 Issue identification . . . . . . . . . . . . . . .

8.1.2.2 Performance allocation . . . . . . . . . . . . . .

8.1.2.3 Data collection and analysis . . . . . . . . . . .

8.1.2.4 Issue resolution documentation . . . . . . . . . .

8.1.2.5 Application of the issue resolution strategy . .

8.2 Issues to be resolved and information required during site characterization . . . . . . . . . . . . . . . . . . . . .

8.2.1 Issues to be resolved . . . . . . . . . . . . . . . .

8.2.1.1 Site-specific issues hierarchy . . . . . . . . . .

8.2.1.2 Other issues . . . . . . . . . . . . . . . .

8.2.2 Approach to issue resolution . . . . . . . . . . . . .

8.2.3 Issue tracking . . . . . . . . . . . . . . . . . .

8.3 Planned tests, analyses, and studies . . . . . . . . . .

8.3.1 Site program . . . . . . . . . . . . . . . . . .

8.3.1.1 Overview of the site program: Role of alternative

conceptual models ..... . . . . . . . . . 8.3.1.1- 1

8.3.1.2 Overview of the geohydrology program:

Description of the present and expected geo-

hydrologic characteristics required by the per-

formance and design issues .......... 8.3.1.2- 1

8.3.1.2.1 Investigation: Studies to provide a

description of the regional hydrologic

system .. . . . . . . . . . . . 8.3.1.2- 92

8.3.1.2.1.1 Study: Charanterization of the mete-

orology for regional hydrology . . . . 8.3.1.2- 97

8.3.1.2.1.1.1 Activity: Precipitation and meteor-

olcyical monitoring ........ 8.3.1.2- 97

8.3.1.2.1.2 Study: Characterization of runoff and streamflow ............. 8.3.1.2-102

8.3.1.2.1.2.1 Activity: Surface-water runoff monitoring ........... 8.3.1.2-103

8.3.1.2.1.2.2 Activity: Transport of debris by

severe runoff........... 8.3.1.2-112

8.3.1.2.1.3 Study: Characterization of the regional ground-water flow system . . . . . . . 8.3.1.2-114

8.3.1.2.1.3.1 Activity: Assessment of the regional hydrogeologic data needs in the

saturated zone

$8 \cdot 3 \cdot 1 \cdot 2-114$ 
TABLE OF CONTENTS (continued)

Page

8.3.1.2.1.3.2 Activity: Regional potentiometriclevel distribution and hydrogeologic

framework studies........ 8.3.1.2-118

8.3.1.2.1.3.3 Activity: Fortymile wash recharge

study .. . . . . . . . . . 8.3.1.2-125

8.3.1.2.1.3.4 Activity: Evapotranspiration

studies . . . . . . . . . . 8.3.1.2-134

8.3.1.2.1.4 Study: Regional hydrologic system

synthesis and modeling . . . . . . . 8.3.1.2-137

8.3.1.2.1.4.1 Activity: Conceptualization of

regional hydrologic flow models... 8.3.1.2-137

8.3.1.2.1.4.2 Activity: Subregional two-

dimensional areal hydrologic

modeling . . . . . . . . . 8.3.1.2-139

8.3.1.2.1.4.3 Activity: Subregional two-

dimensional cross-sectional hydro-

logic modeling . . . . . . . . . 8.3.1.2-142

8.3.1.2.1.4.4 Activity: Regional three-dimensional

hydrologic modeling . . . . . . . 8.3.1.2-144

8.3.1.2.1.5 Application of results . . . . . . . . 8.3.1.2-147

8.3.1.2.2 Investigation: Studies to provide a

description of the unsaturated zone hydro-

logic system at the site......... 8.3.1.2-148

8.3.1.2.2.1 Study: Characterization of unsaturated-

zone infiltration.......... 8.3.1.2-157

8.3.1.2.2.1.1 Activity: Characterization of

hydrologic properties of surficial

materials ........... . 8.3.1.2-157

8.3.1.2.2.1.2 Activity: Evaluation of natural

infiltration ........... 8.3.1.2-164

8.3.1.2.2.1.3 Activity: Evaluation of artificial infiltration .......... 8.3.1.2-172

8.3.1.2.2.2 Study: Water movement tracer tests using chloride and chlorine-36

measurements of percolation at

Yucca Mountain .. . . . . . . . 8.3.1.2-179

8.3.1.2.2.2.1 Activity: Chloride and chlorine-36

measurements of percolation at

Yucca Mountain

$8 \cdot 3 \cdot 1 \cdot 2-180$

8.3.1.2.2.3 Study: Characterization of percolation in the unsaturated zone--surface-based study ............... 8.3.1.2-181

8.3.1.2.2.3.1 Activity: Matrix hydrologic properties testing ....... 8.3.1.2-183

8.3.1.2.2.3.2 Activity: Site vertical borehole studies........... 8.3.1.2-200 
TABLE OF CONTENTS (continued)

Page

8.3.1.2.2.3.3 Activity: Solitario Canyon

horizontal borehole study . . . . . 8.3.1.2-221

8.3.1.2.2.4 Study: Characterization of Yucca

Mountain percolation in the unsaturated

zone--exploratory shaft facility study . . 8.3.1.2-232

8.3.1.2.2.4.1 Activity: Intact-fracture test in

the exploratory shaft facility . . . 8.3.1.2-238

8.3.1.2.2.4.2 Activity: Infiltration tests in the

exploratory shaft facility . . . . . 8.3.1.2-252

8.3.1.2.2.4.3 Activity: Bulk-permeability test in

the exploratory shaft facility . . . 8.3.1.2-271

8.3.1.2.2.4.4 Activity: Radial boreho'e tests in

the exploratory shaft facility ... . 8.3.1.2-281

8.3.1.2.2.4.5 Activity: Excavation effects test

in the exploratory shaft facility. . 8.3.1.2-293

8.3.1.2.2.4.6 ictivity: Calico Hills test in

the exploratory shaft facility . . . 8.3.1.2-300

8.3.1.2.2.4.7 Activity: Perched-water test in the

exploratory shaft facility ..... 8.3.1.2-300

8.3.1.2.2.4.8 Activity: Hydrochemistry tests in

the exploratory shaft facility . . . 8.3.1.2-304

8.3.1.2.2.4.9 Activity: Multipurpose-borehole test-

ing near the exploratory shafts... 8.3.1.2-308

8.3.1.2.2.4.10 Activity: Hydrologic properties of major faults encountered in main test level of the exploratory shait facility (ESF) . . . . . . . . 8.3.1.2-316

8.3.1.2.2.5 Study: Diffusion tests in the exploratory shaft facility......... 8.3.1.2-320

8.3.1.2.2.5.1 Activity: Diffusion tests in the exploratory shaft facility .... . 8.3.1.2-320

8.3.1.2.2.6 Study: Characterization of gaseousphase movement in the unsaturated

zone ................ 8.3.1.2-322

8.3.1.2.2.6.1 Activity: Gaseous-phase circulation

study ............. 8.3.1.2-323

8.3.1.2.2.7 Study: Hydrochemical characterization

of the unsaturated zone .. . . . . . 8.3.1.2-334

8.3.1.2.2.7.1 Activity: Gaseous-phase chemical

investigations ......... . 8.3.1.2-334

8.3.1.2.2.7.2 Activity: Aqueous-phase chemical investigations ......... 8.3.1.2-337

8.3.1.2.2.8 Study: Fluid flow in unsaturated, fractured rock . . . . . . . . . . . 8.3.1.2-341

8.3.1.2.2.8.1 Activity: Development of conceptual and numerical models of fluid flow in unsaturated, fractured rock .. 8.3.1.2-342 
8.3.1.2.2.8.2 Activity: Validation of conceptual and numerical models of fluid flow through unsaturated, fractured rock . 8.3.1.2-345

8.3.1.2.2.9 Study: Site unsaturated-zone modeling and synthesis . . . . . . . . . . 8.3.1.2-350

8.3.1.2.2.9.1 Activity: Conceptualization of the unsaturated-zone hydrogeologic system . . . . . . . . . . . 8.3.1.2-351

8.3.1.2.2.9.2 Activity: Selection, development, and testing of hydrologic-modeling computer codes

$\underline{\text { Page }}$

8.3.1.2.2.9.3 Activity: Simulation of the natural hydrogeologic system ....... 8.3.1.2-356

8.3.1.2.2.9.4 Activity: Stochastic modeling and

8.3.1.2.2.9.5 Activity: Site unsaturated-zone integration and synthesis...... 8.3.1.2-361

8.3.1.2.2.10 Application of results......... . 8.3.1.2-362 8.3.1.2.3 Investigation: Studies to provide a description of the saturated zone hydrologic system at the site......... 8.3.1.2-364 8.3.1.2.3.1 Study: Characterization of the site saturated-zone ground-water flow system ............... 8.3.1.2-371

8.3.1.2.3.1.1 Activity: Solitario Canyon fault study in the saturated zone . . . . 8.3.1.2-372

8.3.1.2.3.1.2 Activity: Site potentiometric-level evaluation ........... 8.3.1.2-375

8.3.1.2.3.1.3 Activity: Analysis of single- and multiple-well hydraulic-stress tests... . . . . . . . 8.3.1.2-383

8.3.1.2.3.1.4 Activity: Multiple-well interrerence testing ......... 8.3.1.2-393

8.3.1.2.3.1.5 Activity: Testing of the C-hole sites with conservative tracers... 8.3.1.2-400

8.3.1.2.3.1.6 Activity: Well testing with conservative tracers throughout the site . . . . . . . . . 8.3.1.2-408

8.3.1.2.3.1.7 Activity: Testing of the C-hole sites with reactive tracers.... . 8.3.1.2-417

8.3.1.2.3.1.8 Activity: Well testing with reactive tracers throughout the site ............. 8.3.1.2-423

8.3.1.2.3.2 Study: Characterization of the saturated zone hydrochemistry . . . . . 8.3.1.2-424

8.3.1.2.3.2.1 Activity: Assessment of saturatedzone hydrochemical data availability and needs 
8.3.1.2.3.2.2 Activity: Hydrochemical characterization of water in the upper part of the saturated zone .. . . . . 8.3.1.2-426

8.3.1.2.3.2.3 Activity: Regional hydrochemical characterization . . . . . . . . 8.3.1.2-431

8.3.1.2.3.2.4 Activity: Synthesis of saturatedzone hydrochemistry . . . . . . . 8.3.1.2-433 8.3.1.2.3.3 Study: Saturated zone hydrologic system synthesis and modeling .......... 8.3.1.2-434

8.3.1.2.3.3.1 Activity: Conceptualization of saturated zone flow models within the boundaries of the accessible environment ............ 8.3.1.2-435

8.3.1.2.3.3.2 Activity: Development of fracture network model ........... 8.3.1.2-436

8.3.1.2.3.3.3 Activity: Calculation of flow paths, fluxes, and velocities within the saturated zone to the accessible environment .......... 8.3.1.2-441

8.3.1.2.3.4 Application of results . . . . . . . 8.3.1.2-444 8.3.1.2.4 Schedule for the geohydrology program . . . 8.3.1.2-445 8.3.1.3 Overview of the geochemistry program: Description of the present and expected geochemical characteristics required by the performance and design issues......... 8.3.1.3- 1

8.3.1.3.1 Investigation: Studies to provide information on water chemistry within the potential emplacement horizon and along potential flow paths .......... 8.3.1.3-36

8.3.1.3.1.1 Study: Ground-water chemistry model , . 8.3.1.3- 37

8.3.1.3.1.2 Application of results . . . . . . . 8.3.1.3-39 8.3.1.3.2 Investigation: Studies to provide information on mineralogy, petrology, and rock chemistry within the potential emplacement horizon and along potential flow paths . . 8.3.1.3-40

8.3.1.3.2.1 Study: Mineralogy, petrology, and Themistry of transport pathways . . . . . 8.3.1.3-43

8.3.1.3.2.1.1 Activity: Petrologic stratigraphy of the Topopah Spring Member ... . 8.3.1.3-43

8.3.1.3.2.1.2 Activity: Mineral distributions between the host rock and the accessible environment .. . . . 8.3.1.3- 45

8.3.1.3.2.1.3 Activity: Fracture mineralogy ... . 8.3.1.3- 47 8.3.1.3.2.2 Study: History of mineralogic and geochemical alteration of Yucca Mountain. . 8.3.1.3- 49

8.3.1.3.2.2.1 Activity: History of mineralogic and geschemical alteration of Yucca Mountain 
8.3.1.3.2.2.2 Activity: Smectite, zeolite, inanganese minerals, glass dehydration, and transformation ..... 8.3.1.3- 52

8.3.1.3.2.3 Application of results ......... . 8.3.1.3- 54 8.3.1.3.3 Investigation: Studies to provide information required on stability of minerals and glasses............ 8.3.1.3- 55

8.3.1.3.3.1 Study: Natural analog of hydrothermal systems in tuff............ 8.3.1.3- 56

8.3.1.3.3.2 Study: Kinetics and thermodynamics of mineral evolution.......... 8.3.1.3- 59

?.3.1.3.3.2.1 Activity: Kinetic studies of zeolite and related framework silicates........... 8.3.1.3-60

8.3.1.3.3.2.2 Act vity: Determination of endnumber free energies for clinoptilolite, heulandite, albite, and analcime ........... 8.3.1.3-61

8.3.1.3.3.2.3 Activity: Solid solution descriptions of clinoptilolite-heulandite and analcjme .......... 8.3.1.3- . 3

8.3.1.3.3.3 Study: Conceptual model of mineral evolution.............. 8.3.1.3-64

8.3.1.3.3.4 Application of results ........ . 8.3.1.3-65 8.3.1.3.4 Investigation: Studies to provide the information required on rationuclide retardation by sorption processes along flow paths to the accessible environment . . 8.3.1.3- 65 8.3.1.3.4.1 Study: Batch sorption studies...... 8.3.1.3- 68

8.3.1.3.4.1.1 Activity: Batch sorption measurements as a function of solid phase composition........... 8.3.1.3- 6

8.3.1.3.4.1.2 Activity: Sorption as a function of sorbing element concentrations (isotherms) ........... 8.3.1.3-74

8.3.1.3.4.1.3 Activity: Sorption as a function of ground-water composition ...... 8.3.1.3-76

8.3.1.3.4.1.4 Activity: Sorption on particulates and colloids . .......... 8.3.1.3- 77

8.3.1.3.4.1.5 Activity: Statistical analysis of sorption data............3.1.3- 79

8.3.1.3.4.2 Study: Biological sorption and iranjpert............. 8.3.1.3-80

8.3.1.3.4.3 Study: Development of sorption models . . 8.3.1.3-83 8.3.1.3.4.4 Application of results ........ . 8.3.1.3-84 
TABLE OF CONTENTS (continued)

Page

8.3.1.3.5 Investigation: Studies to provide the information required on radionuclide retardation by precipitation processes along flow paths to tho accessible environment . . 8.3.1.3-85

8.3.1.3.5.1 itudy: Dissolved species concentration limits . . . . . . . . . . 8.3.1.3-88 8.3.1.3.5.1.1 Activity: Solubility measurements . . 8.3.1.3-88 8.3.1.3.5.1.2 Activity: Speciation measurements . 8.3.1.3-91

8.3.1.3.5.1.3 Activity: Solubility modeling . . . 8.3.1.3- 92 8.3.1.3.5.2 St.2dy: Colloid behavior ........ . 8.3.1.3- 93 8.3.1.3.5.2.1 Activity: Colloid formation char-

8.3.1.3.5.2.2 Activity: C'olloid modeling..... 8.3.1.3- 94 8.3.1.3.5.3 Application of results . . . . . . . . 8.3.1.3- 94 8.3.1.3.6 Investigation: Studies to provide the information required on radionuclide retardation by dispersive, diffusive, and advective transport processes along flow paths to the accessible environment... . 8.3.1.3-95 8.3.1.3.6.1 Study: Dynamic transport column experiments . . . . . . . . . . 8.3.1.3-100 8.3.1.3.6.1.1 Activity: Crushed tuff column experiments ........... 8.3.1.3-101

8.3.1.3.6.1.2 Activity: Mass transfer kinetics. . 8.3.1.3-105 8.3.1.3.6.1.3 Activity: Unsaturated tuff columss............ 8.3.1.3-107

8.3.1.3.6.1.4 Activity: Fractured tuff column studies.......... 8.3.1.3-109

8.3.1.3.6.1.5 Activity: Filtration....... . 8.3.1.3-110 8.3.1.3.6.2 Study: Diffusion............ 8.3.1.3-112 8.3.1.3.6.2.1 Activity: Uptake of radionuclides on rock beakers in a saturated system ............. 8.3.1.3-112

8.3.1.3.6.2.2 Activity: Diffusion through a saturated tuff slab........ 8.3.1.3-113

8.3.1.3.6.2.3 Activity: Diffusion in an unsaturated tuff block ......... 8.3.1.3-114

8.3.1.3.6.3 Application of results . . . . . . . . 8.3.1.3-115

8.3.1.3.7 Investigation: Studies to provide the information required on radionuclide retardation by all processes along flow paths to the accessible environment

8.3.1.3.7.1 Study: Retardation sensitivity analysis ............. 8.3.1.3-118

8.3.1.3.7.1.1 Activity: Analysis of physical/ chemical processes affecting transport 
8.3.1.3.7.1.2 Activity: Geochemical/geophysical model of Yucca Mountain and integrated geochemical transport calculations . . . . . . . . 8.3.1.3-123

8.3.1.3.7.1.3 Activity: Transport models and related support . . . . . . . . 8.3.1.3-125

8.3.1.3.7.2 Study: Demonstration of applicability of laboratory data to repository transport calculations......... 8.3.1.3-127

8.3.1.3.7.3 Application of results . . . . . . . 8.3.1.3-133

8.3.1.3.8 Investigation: Studies to provide the required information on retardation of gaseous radionuclides along flow paths to the accessible environment . . . . . . . 8.3.1.3-134

8.3.1.3.8.1 Study: Gaseous radionuclide transport calculations and measurements . . . . . 8.3.1.3-135

8.3.1.3.8.1.1 Activity: Physical transport mechanisms and rates--retardation mechanisms and transport with retardation ......... 8.3.2.3-136

8.3.1.3.8.1.2 Activity: Gas transport measurements ........ 8.3.1.3-137

8.3.1.3.8.2 Application of results . . . . . . . 8.3.1.3-138 8.3.1.3.9 Schedule for the geochemistry program . . . . 8.3.1.3-138 8.3.1.4 Overview of the rock characteristics program: Description of the present and expected rock characteristics required by performance and design issues................ 8.3.1.4- 1

8.3.1.4.1 Investigation: Development of an integrated drilling program and integration of geophysical activities............ 8.3.1.4- 24

8.3.1.4.1.1 Activity: Development of an integrated drilling program .......... 8.3.1.4- 24

8.3.1.4.1.2 Activity: Integration of geophysical activities ............ 8.3.1.4- 26

8.3.1.4.2 Investigation: Geologic framework of the Yucca Mountain site........... 8.3.1.4- 28

8.3.2.4.2.1 Study: Characterization of the vertical and lateral distribution of stratigraphic units within the site area ... 8.3.1.4- 32

8.3.1.4.2.1.1 Activity: Surface and subsurface stratigraphic studies of the host rock and surrounding units . . . . . 8.3.1.4- 32

8.3.1.4.2.1.2 Activity: Surface-based geophysical surveys . . . . . . . . . . 8.3.1.4- 41

8.3.1.4.2.1.3 Activity: Borehole geophysical surveys............. 8.3.1.4- 57

8.3.1.4.2.1.4 Activity: Petrophysical properties tssting............ 8.3.1.4- 59 
TABLE OF CONTENTS (continued)

Page

8.3.1.4.2.1.5 Activity: Magnetic properties and stratigraphic correlations ..... 8.3.1.4-60

8.3.1.4.2.1.6 Integration of geophysical activities ............ 8.3.1.4-64

8.3.1.4.2.2 Study: Characterization of the struc-

tural features within the site area... . 8.3.1.4- 65

8.3.1.4.2.2.1 Activity: Geologic mapping of zonal

features in the Paintbrush Tuff. . . 8.3.1.4- 66

8.3.1.4.2.2.2 Activity: Surface-fracture network

studies............. 8.3.1.4- 68

8.3.1.4.2.2.3 Activity: Borehole evaluation of

faults and fractures ........ 8.3.1.4-70

8.3.1.4.2.2.4 Activity: Geologic mapping of the

exploratory shaft and drifts ... . 8.3.1.4-74

8.3.1.4.2.2.5 Activity: Seismic tomography/

vertical seismic profiling .. . . 8.3.1.4- 79

8.3.1.4.2.3 Study: Three-dimensional geologic

model . . . . . . . . . . . 8.3.1.4-81

8.3.1.4.2.3.1 Activity: Development of a three-

dimensional geologic model of the

site area........... 8.3.1.4-81

8.3.1.4.2.4 Application of results. . ........ 8.3.1.4-82

8.3.1.4.3 Investigation: Development of three-

dimensional models of rock characteristics

at the repository site............ 8.3.1.4-84

8.3.1.4.3.1 Study: Systematic acquisition of site-

specific subsurface information... . 8.3.1.4-87

8.3.1.4.3.1.1. Activity: Systematic drilling

program ............. 8.3.1.4- 87

8.3.1.4.3.2 Study: Three-dimensional rock charac-

teristics models. ........... 8.3.1.4-100

8.3.1.4.3.2.1 Activity: Development of threedimensional models of rock charac-

teristics at the repository site . . 8.3.1.4-100

8.3.i.4.3.3 Application of results . . . . . . . 8.3.1.4-102

8.3.1.4.4 Schedule for the rock characteristics

program . . . . . . . . . . . 8.3.1.4-103 
TABLE OF CONTENTS

VOLUME V

Page

8.3.1.5 Overview of the climate program: Description of

future climate conditions, required by the

performance and design issues . . . . . . . . 8.3.1.5- 1

8.3.1.5.1 Investigation: Studies to provide the information required on nature and rates of change in climatic conditions to predict

future climates ............. 8.3.1.5-33

8.3.1.5.1.1 Study: Characterization of modern regional climate . . . . . . . . . . .

8.3.1.5.1.1.1 Activity: Synoptic characterization of regional climate. . . . . . . .

8.3.1.5.1.2 : Study: Paleoclimate study: lake, playa, marsh deposits... . . . .

$8.3 \cdot 1 \cdot 5-40$

$8.3 \cdot 1.5-40$

$8 \cdot 3 \cdot 1 \cdot 5-42$

8.3.1.5.1.2.1 Activity: Paleontologic analyses.

8.3.1.5.1.2.2 Activity: Analysis of the stratigraphy-sedimentology of marsh, lacustrine, and playa deposits . . . . .

8.3.1.5.1.2.3 Activity: Geochemical analyses of lake, marsh, and playa deposits... 8.3.1.5- 49

8.3.1.5.1.2.4 Activity: Chronologic analyses of lake, playa, and marsh denosits . . 8.3.1.5- 51

8.3.1.5.1.3 Study: Climatic implications of terrestrial paleoecology .........

8.3.1.5.1.3.1 Activity: Analysis of pack rat middens...... . . . . . . .

8.3.1.5.1.3.2 Activity: Analysis of polien samples.............

8.3.1.5.1.3.3 Activity: Determination of

vegetation-climate relationships . 8.3.1.5- 57

8.3.1.5.1.4 Study: Analysis of the paleoenvironmental history of the Yucca Mountain

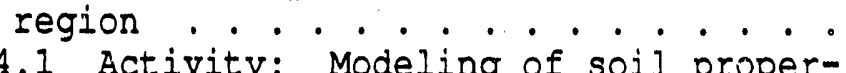

8.3.1.5.1.4.1 Activity: Modeling of soil properties in the Yucca Mountain region.

8.3.1.5.1.4.2 Activity: Surficial deposits

mapping of the Yucca Mountain area . $8.3 .1 .5-66$

8.3.1.5.1.4.3 Activity: Eolian history of the Yucca Mountain region........

8.3.1.5.1.5 Study: Paleoclimate-paleoenvironmental synthesis . . . . . . . . . . . . .

8.3.1.5.1.5.1 Activity: Paleoclimatepaleoenvironmental synthesis ....

$8.3 \cdot 1.5-42$

$8.3 \cdot 1.5-47$

$8 \cdot 3 \cdot 1 \cdot 5-54$

$8 \cdot 3 \cdot 1 \cdot 5-54$

$8.3 \cdot 1.5-56$

$8.3 .1 .5-59$

$8.3 .1 .5-61$

$8.3 \cdot 1.5-72$

$8 \cdot 3 \cdot 1.5-76$

$8 \cdot 3 \cdot 1 \cdot 5-77$

8.3.1.5.1.6 Study: Characterization of the future regional climate and environments . . . 8.3.1.5-78

8.3.1.5.1.6.1 Activity: Global climate modeling. 8.3.1.5.1.6.2 Activity: Regional climate

$8.3 \cdot 1.5-79$

modeling . . . . . . . . . . .

$8.3 .1 .5-83$ 
8.3.1.5.1.6.3 Activity: Linked global-regional climate modeling. . . ...... . 8.3.1.5-84

8.3.1.5.1.6.4 Activity: Empirical climate modeling ........... 8.3.1.5-86

8.3.1.5.1.7 Application of results . . . . . . . 8.3.1.5-88

8.3.1.5.2 Investigation: Studies to provide the information required on potential effects of future climatic conditions on hydrologic characteristics. . . . . . . . . . . . .

$8.3 \cdot 1.5-89$

8.3.1.5.2.1 Study: Characterization of the Quaternary regional hydrology ..... 8.3.1.5-93

8.3.1.5.2.1.1 Activity: Regional paleoflood evaluation ............ 8.3.1.5-94

8.3.1.5.2.1.2 Activity: Quaternary unsaturated zone hydrochemical analysis ..... 8.3.1.5-96

8.3.1.5.2.1.3 Activity: Evaluation of past discharge areas .. . . . . . . . .

$8.3 \cdot 1.5-98$

8.3.1.5.2.1.4 Activity: Analog recharge studies $8 \cdot 3 \cdot 1 \cdot 5-106$

8.3.1.5.2.1.5 Activity: Studies of calcite and opaline silica vein deposits . . . 8.3.1.5-110

8.3.1.5.2.2 Study: Characterization of the future regional hydrology due to climate changes . . . . . . . . . . . . . . .

8.3.1.5.2.2.1 Activity: Analysis of future surface hydrolcgy due to climate changes . . . . . . . . .

\subsection{2 Activity: Analysis of future} unsaturated zone hydrology due to climate changes..........

8.3.1.5.2.2.3 Activity: Synthesis of effects of possible future recharge due to climate changes on hydrologic characteristics of the Yucca Mountain saturated zone . . . . . . . . . $8 \cdot 3 \cdot 1 \cdot 5-118$ $8 \cdot 3 \cdot 1 \cdot 5-118$ $8 \cdot 3 \cdot 1 \cdot 5-119$

8.3.1.5.2.3 Application of results . . . . . . . . $8 \cdot 3 \cdot 1 \cdot 5-121$ $8 \cdot 3 \cdot 1 \cdot 5-122$ 8.3.1.5.3 Schedule for the climate program . . . . . 8.3.1.6 Overview of the erosion program: Description of the future erosional rates required by the performance and design issue . . . . . . . . .

8.3.1.6.1 Investigation: Studies to determine present locations and rates of surface erosion . . . 8.3.1.6.1.1 Study: Distribution and characteristics of present and past erosion . . . . . . 8.3.1.6.1.1.1 Activity: Development of a geomorphic map of Yucca Mountain... .

8.3.1.6.1.1.2 Activity: Analysis of the downcutting history of Fortymile Wash and its tributaries........ . 
8.3.1.6.1.1.3 Activity: An analysis of hillslope erosion at Yucca Mountain.... 8.3.1.6- 13

8.3.1.6.1.2 Application of results ........ 8.3.1.6- 15

8.3.1.6.2 Investigation: Potential effects of future climatic conditions on locations and rates of erosion ............... 8.3.1.6- 15

8.3.1.6.2.1 Study: Influence of future climatic conditions on locations and rates of erosion.............. 8.3.1.6- 18

8.3.1.6.2.1.1 Activity: Synthesis and data evaluation of impact of future climatic conditions on locations and rates of erosion ........ information required to determine the potential effects of future tectonic activity on locations and rates of erosion......

8.3.1.6.3.1 Study: Evaluation of the effects of future tectonic activity on erosion at Yucca Mountain . . . . . . .

8.3.1.6.3.1.1 Activity: Synthesis and data evaluation of the impact of future uplift or subsidence and faulting on erosion at Yucca Mountain and vicinity

$8 \cdot 3 \cdot 1 \cdot 6-22$

8.3.1.6.3.2 Application of results . . . . . . . . . $8.3 .1 .6-19$ $8 \cdot 3 \cdot 1 \cdot 6-22$ $8.3 .1 .6-23$

8.3.1.6.4 Investigation: Potential effects of erosion on hydrologic, geochemical, and rock characteristics. . . . . . . . . . . . . .

8.3.1.6.4.1 Study: Development of a topical report to address the effects of erosion on the hydrologic, geochemical, and rock characteristics at Yucca Mountain . . 8.3.1.6- 27

8.3.1.6.4.2 Application of results . . . . . . . $8.3 .1 .6-23$ $8.3 .1 .6-27$ 8.3.1.6.5 Schedule for the erosion program . . . . . 8.3.1.7 Overview of rock dissolution program: Description of rock dissolution required by the performance and design issues . . . . . . . . . 8.3.1.7- 1

8.3.1.7.1 Investigation: Rates of dissolution of crystaliine and noncrystalline components in tuff................. 8.3.1.7- 1

8.3.1.7.1.1 Application of results . . . . . . . . $8.3 \cdot 1.7-2$

8.3.1.7.1.2 Schedule and milestones . . . . . . . . 8.3.1.7- 2

8.3.1.8 Overview of the postclosure tectonics program: Description of future tectonic processes and events required by the performance and design issues 
8.3.1.8.1 Investigation: Studies to provide information required on direct releases resulting from volcanic activity .. . . . . . . . .

$8.3 .1 .8-48$ 8.3.1.8.1.1 Study: Probability of a volcanic eruption penetrating the repository... .

$8.3 .1 .8-51$

8.3.1.8.1.1.1 Activity: Location and timing of volcanic events......... .

8.3.1.8.1.1.2 Activity: Evaluation of the struc-

$8.3 \cdot 1.8-51$ tural controls of basaltic volcanic

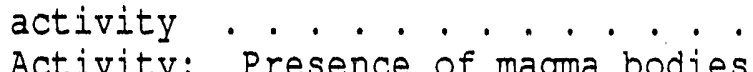

8.3.1.8.1.1.3 Activity: Presence of magma bodies in the vicinity of the site.....

8.3.1.8.1.1.4 Activity: Probability calculations and assessment . . . . . . . . .

8.3.1.8.1.2 Study: Effects of a volcanic eruption penetrating the repository .......

8.3.1.8.1.2.1 Activity: Effects of Strombolian eruptions ..............

8.3.1.8.1.2.2 Activity: Effects of hydrovolicanic eruptions............

8.3.1.8.1.3 Application of results . . . . . . . 8.3.1.8.2 Investigation: Studies to provide information required on rupture of waste packages due to tectoric events. . . . . . . . . . .

8.3.1.8.2.1 Study: Analysis of waste package rupture due to tectonic processes and events ... . . . . . . . . . . .

8.3.1.8.2.1.1 Activity: Assessment of waste package rupture due to igneous intrusion.

$8.3 .1 .8-52$

$8.3 .1 .8-55$

$8.3 .1 .8-57$

$8.3 \cdot 1.8-59$

$8.3 .1 .8-59$

$8.3 .1 .8-60$

$8.3 .1 .8-62$

$8.3 .1 .8-63$

$8.3 .1 .8-66$

8.3.1.8.2.1.2 Activity: Calculation of the number
of waste packages intersected by a fault............. 8.3.1.8- 67

8.3.1.8.2.1.3 Activity: Probability and rate of faulting . . . . . . . . . . . . 8.3.1.8.2.1.4 Activity: Assessment of waste pack-

$8.3 .1 .8-68$ age rupture due to faulting . . . . .

$8.3 .1 .8-69$

8.3.1.8.2.1.5 Activity: Assessment of postclosure

ground motion in the subsurface... 8.3.1.8- 70

8.3.1.8.2.1.6 Activity: Nature, age, and rate of folding and deformation in the repository horizon

8.3.1.8.2.1.7 Activity: Assessment of waste package rupture due to folding and deformation...........

$8.3 .1 .8-66$

$8.3 .1 .8-71$

$8.3 .1 .8-72$

8.3.1.8.2.2 Application of results ....... 8.3.1.8- 72 
8.3.1.8.3 Investigation: Studies to provide information required on changes in unsaturated and saturated zone hydrology due to tectonic events . . . . . . . . . .

8.3.1.8.3.1 Study: Analysis of the effects of

tectonic processes and events on average percolation flux rates over the repository: Annual probability of '

$8.3 \cdot 1.8-73$

8.3.1.8.3.1.1 Activity: Annual probability of
volcanic or igneous events in the contrulled area.......... 8.3.1.8-82

8.3.1.8.3.1.2 Activicy: Assessment of the effects of igneous intrusions and volcanic events on flux rates ........

8.3.1.8.3.1.3 Activity: Faulting rates, recurrence intervals, and probable cameolative offset in 10,000 yr .....

8.3.1.8.3.1.4 Activity: Effects of faulting on

average flux rates . ....... 8.3.1.8-85

8.3.1.8.3.1.5 Activity: Assessment of the effects of faulting on flux rates......

8.3.1.8.3.1.6 Activity: Uplift rates in the controlled area . . . . . . . . . . .

8.3.1.8.3.1.7 Activity: Assessment of the effects $8.3 .1 .8-82$ of folding, uplift, and subsidence on flux rates...........

8.3.1.8.3.2 Study: Analysis of the effect of tectonic processes and events on changes in water-table elevation

8.3.1.8.3.2.1 Activity: Thermal and barrier-toflow effects of igneous intrusions on water-table elevation ......

$8.3 .1 .8-85$

$8.3 .1 .8-87$

$8.3 .1 .8-87$

$8.3 .1 .8-83$

$8.3 .1 .8-84$

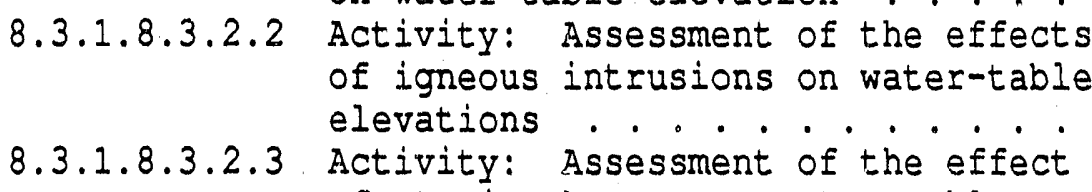

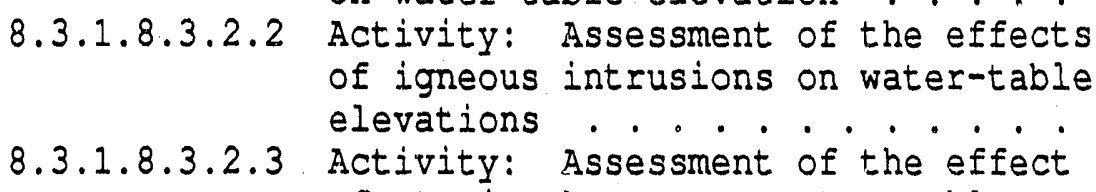

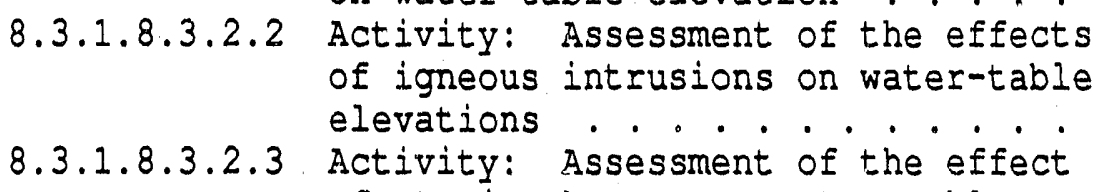
of strain changes on water-table elevations .............

8.3.1.8.3.2.4 Activity: Assessment of the effect of folding, uplift, or subsidence

on water-table elevation ..... 8.3.1.8-92

8.3.1.8.3.2.5 Activity: Effects of faulting on

water-table elevation ...... 8.3.1.8-93

8.3.1.8.3.2.6 Activity: Assessment of the effect of faulting on water-table elevation...........

$8.3 .1 .8-88$

$8.3 .1 .8-88$

$8.3 .1 .8-89$

$8.3 .1 .8-91$

$8.3 .1 .8-93$ 
TABLE OF CONTENTS (continued)

Page

8.3.1.8.3.3 Study: Analysis of the effects of tectonic processes and events on local fracture permeability and effective porosity . . . . . . . . . . . . . . .

$8.3 .1 .8-94$

8.3.1.8.3.3.1 Activity: Assessment of the effects of igneous intrusions on local fracture permeability and effective porosities .............

8.3.1.8.3.3.2 Activity: Assessment of the effects

$8.3 .1 .8-95$ of faulting on local fracture permeability and effective porosities. .

8.3.1.8.3.3.3 Activity: Assessment of the effects $8.3 .1 .8-95$ of stress or strair on hydrologic properties of the rock mass.... .

$8.3 .1 .8-96$ 8.3.1.8.3.4 Application of results . . . . . . . . 8.3.1.8-97 8.3.1.8.4 Investigation: Studies to provide information required on changes in rock geochemical properties resulting from tectonic processes . . . . . . . . .

8.3.1.8.4.1 Study: Analysis of the effects of tectonic processes and events on rock geochemical properties . . . . . . . .

8.3.1.8.4.1.1 Activity: Assessment of the change in rock geochemical properties due to igreous intrusions ........

8.3.1.8.4.1.2 Activity: Assessment of the degree of mineral change along fault zones in $10,000 \mathrm{yr}$..........

8.3.1.8.4.1.3 Activity: Assessment of the effects of fault of sset on travel pathway. . 8.3.1.8.4.1.4 Activity: Essessment of the degree of mineral change in the controlled area resulting frcin tectonically induced change in water-table elevations

$8 \cdot 3 \cdot 1 \cdot 8-104$

8.3.1.8.4.2 Application of results . . . . . . . 8.3.1.8-105

8.3.1.8.5 Investigation: Studies to provide the information required by the analysis and assessment investigations of the tectonics program . . . . . . . . . . . . . . . . .

$8.3 .1 .8-98$

$8 \cdot 3 \cdot 1 \cdot 8-101$

$8 \cdot 3 \cdot 1 \cdot 8-101$

$8 \cdot 3 \cdot 1 \cdot 8-102$

$8 \cdot 3 \cdot 1 \cdot 8-103$

8.3.1.8.5.1 Study: Characterization of volcanic
features . . . . . . . . .

$8 \cdot 3 \cdot 1 \cdot 8-105$

8.3.1.8.5.1.1 Activity: Volcanism drillholes..

$8 \cdot 3 \cdot 1 \cdot 8-107$

$8.3 \cdot 1 \cdot 8 \cdot 5 \cdot 1.2$

Activity:

Geochronology studies. .

$8 \cdot 3 \cdot 1 \cdot 8-108$

$8 \cdot 3 \cdot 1 \cdot 8 \cdot 5 \cdot 1.3$

Activity:

Field geologic studies. .

8.3 .1 .8 .5 .1 .4

Activity: Geochemistry of scoria

sequences . . . . . . . . . . . . .

$8 \cdot 3 \cdot 1 \cdot 8-112$

$8 \cdot 3 \cdot 1 \cdot 8-116$

$8.3 \cdot 1.8 \cdot 5 \cdot 1.5$

Activity: Geochemical cycles of

$8 \cdot 3 \cdot 1 \cdot 8-119$

basaltic volcanic fields

$8 \cdot 3 \cdot 1 \cdot 8-121$ 
8.3.1.8.5.2 Study: Characterization of igneous intrusive features . . . . . . . . . .

$8 \cdot 3 \cdot 1 \cdot 8-123$

8.3.1.8.5.2.1 Activity: Evaluation of depth of curie temperature isotherm . . . . 8.3.1.8-1.24

8.3.1.8.5.2.2 Activity: Chemical and physical changes around dikes ....... 8.3.1.8-125

8.3.1.8.5.2.3 Activity: Heat flow at Yucca Mountain and evaluation of regional ambient heat flow and local heat flow anomalies . . . . . . . . . .

8.3.1.8.5.3 Study: Investigation of folds in Miocene and younger rocks of region... $8.3 \cdot 1 \cdot 8-129$

8.3.1.8.5.3.1 Activity: Evaluation of folds in Neogene rocks of the region.... 8.3.1.8-130

8.3.1.8.5.4 Application of results ......... $8 \cdot 3 \cdot 1 \cdot 8-131$

8.3.1.8.6 Schedule for the postclosure tectonics program . . . . . . . . . . . . . . . . .

8.3.1.9 Overview of the human interference program:

Description of potential future human activities at or near the site, required by performance and design issues

8.3.1.9.1 Investigation: Studies to provide the information required on natural phenomena and human activities that might degrade surface markers and monuments . . . . . . .

$8 \cdot 3 \cdot 1 \cdot 8-131$

$8.3 \cdot 1.9-1$

8.3.1.9.1.1 Study: An evaluation of natural
processes that could affect the long-term survivability of the surface marker system at Yucca Mountain... . .

8.3.1.9.1.1.1 Activity: Synthesis of tectonic, seismic, and volcanic hazards data from other site characterization activities ............

8.3.1.9.1.1.2 Activity: Synthesis: evaluation of the effects of future erosion and deposition on the survivability of the marker system at Yucca Mountain

8.3.1.9.1.2 Application of results . . . . . . . $8.3 .1 .9-20$

8.3.1.9.2 Investigation: Studies to provide the information required on present and future value of energy, mineral, land, and groundwater resources...............

8.3.1.9.2.1 Study: Natural resource assessment of Yucca Mountain, Nye County, Nevada. . 
TABLE OF CONTENTS (continued)

Päıge

8.3.1.9.2.1.2 Activity: Geophysical/geologic appraisal of the site relative to mineral resources ..........

8.3.1.9.2.1.3 Activity: Assessment of the potential for geothermal energy at yucca Mountain, Nevada . . . . . . . .

8.3.1.9.2.1.4 Activity: Assessment of hydrocarbon resources at and near the site. . . 8.3.1.9.2.1.5 Activity: Mineral and energy asjessment of the site, comparison to known mineralized areas, and the potential for undiscovered resources and future exploration . . . . . . .

8.3.1.9.2.2 Study: Water resource assessment of Yucca Mountain, Nevada . . . . . . .

8.3.1.9.2.2.1 Activity: projected trends in local and regional ground-water development, and estimated withdrawal rates in southern Nevada, proximal to Yucca Mountain . . . . . . . . . $8.3 .1 .9-34$ $8.3 .1 .9-37$

$8.3 .1 .9-39$

$8.3 .1 .9-42$

8.3.1.9.2.3 Application of results . . . . . . . . $8.3 .1 .9-43$ 8.3.1.9- 44

8.3.1.9.3 Investigation: Studies to provide the information required on potential effects of exploiting natural resources on hydrologic, geochemical, and rock characteristics...

8.3.1.9.3.1 Study: Evaluation of data needed to support an assessment of the likelihood of future inadvertent human intrusion at Yucca Mountain as a result of exploration and/or extraction of natural resources ............ $8.3 \cdot 1.9 \cdots 46$

8.3.1.9.3.1.1 Activity: Compilation of data to support the assessment calculation of the potential for inadvertent human intrusion at Yucca Mountain ............

8.3.1.9.3.2 Study: An evaluation of the potential effects of exploration for, or extraction of, natural resources on the hydrologic characteristics at Yucca Mountain...

8.3.1.9.3.2.1 Activity: An analysis of the potential effects of future ground-water withdrawals on the hydrologic system in the vicinity of Yucca Mountain, Nevada . . . . . . . . . . . $8.3 .1 .9-49$

8.3.1.9.3.2.2 Activity: Assessment of initiating events relater to human interference that are considered not to be sufficiently credible or significant to warrant further investigation . . . . 


\section{Page}

8.3.1.9.3.3 Application of results . . . . . . . . 8.3.1.9- 51

8.3.1.9.4 Schedule and milestones for Site Program

8.3.1.9 (human interference). . . . . . . 8.3.1.9- 51

8.3.1.10 Overview of population density and distribution program: Description of population density and distribution required by the performance and design issues . . . . . . . . . .

8.3.1.11 Overview of land ownership and mineral rights vrogram: Description of status and plans for land ownership and mineral rights required by the perfoimance and design issues

8.3.1.12 Overview of the meteorology program: jescription of meteorological conditions required by

the performance and design issues . . . .

8.3.1.12.1 Investigation: Studies to provide data
on regional meteorological conditions

8.3.1.12.1.1 Study: Characterization of the

8.3.1.12.1.2 Study: Plan for synthesis of Yucca Mountain Project meteorological

8.3.1.12.1.3 Application of results . . . . . . . monitoring ............. . 8.3.1.12-11

8.3.1.12.2 Investigation: Studies to provide data on atmospheric and meteorological phenomena at potential locations of surface facilities................ 8.3.1.12- 14

8.3.1.12.2.1 Study: Meteorological data collection at the Yucca Mountain site...... 8.3.1.12.2.1.1 Activity: Site meteorological 8.3.1.12.2.1.2 Activity: Data sumary for input to dose assessments ........

8.3.1.12.2.2 Application of results . . . . . . . .

8.3.1.12.3 Investigation: Studies to provide data on the location of population centers relative to wind patterns in the general region of the site.................

8.3.1.12.3.1 Application of results. . . . . . . 8.3.1.12.4 Investigation: Studies to provide data on potential extreme weather phenomena and their recurrence intervals . . . . . . . .

8.3.1.12.4.1 Study: Characterize the potential extreme weather phenomena and their recurrence intervals... . . . . . $8.3 .1 .12-16$ $8.3 .1 .12-16$ $8.3 .1 .12-22$ 8.3.1.12- 24 8.3.1.11- 1 $8.3 .1 .12-1$ $8.3 .1 .12-8$ $8 \cdot 3 \cdot 1 \cdot 12-10$ $8.3 \cdot 1.12-13$

8. 3.1.12- 25

$8.3 .1 .12-26$

$8.3 .1 .12-26$

8.3.1.12- 27

8.3.1.12.4.2 Application of results . . . . . . . .
3.1.12.5 Schedule for the meteorology program.
. . . . .

8.3.1.13 Overview of offsite installations and operations program: Description of the offsite installations and operations required by performance and design issues 
8.3.1.13.1 Investigation: Determination of nearby industrial, transportation, and military installations and operations (nuclear and nonnuclear) ............. 8.3.1.13- 2

8.3.1.13.1.1 Activity: Identify near-site activities ............. 8.3.1.13- 3

8.3.1.13.1.2 Activity: Characterize nuclear fuel cycle facilities in the area.... . 8.3.1.13- 4

8.3.1.13.1.3 Activity: Characterize all nuclear facilities not associated with the nuclear fuel cycle near the Yucca Mountain site ............ 8.3.1.13- 5

8.3.1.13.1.4 Application of results . . . . . . . 8.3.1.13.2 Investigation: Potential impacts of nearby installations and operations . . . . . . .

8.3.1.13.2.1 Activity: Evaluate near-site

8.3.1.13.2.2 Activity: Evaluation of the impact of $8.3 \cdot 1.13-8$ nuclear fuel cycle operations near the Yucca Mountain site and Las Vegas . .

8.3.1.13.2.3 Activity: Evaluate the impact of all nuclear facilities not associated with the nuclear fuel cycle near the Yucca Mountain site Activity: Evaluate the impact of ground motion from nuclear testing activities at the Nevada Test Site. . $8.3 .1 .13-9$

8.3.1.13.2.5 Application of results........ 8.3.1.13- 11 $8.3 .1 .13-11$ 8.3.1.13.3 Schedule for offsite installations. . . . 8.3.1.13- 11 8.3.1.14 Overview of the surface characteristics program: Description of the surface characteristics required by the performance and design issues ... . . . . . . . . . . . . . .

8.3.1.14.1 Investigation: Studies to provide the topographic characteristics of potential locations of surface facilities .... . 8.3.1.14- 18 8.3.1.14.1.1 Application of results........ . 8.3.1.14- 26 8.3.1.14.2 Investigation: Studies to provide soil and rock properties of potential locations of surface facilities ......... 8.3.1.14- 27

8.3.1.14.2.1 Study: Exploration program ...... 8.3.1.14- 31 8.3.1.14.2.1.1 Activity: Site reconnaissance. . . 8.3.1.14- 33 8.3.1.14.2.1.2 Activity: Preliminary 8xploration .......... 8.3.1.14-40 8.3.1.14.2.1.3 Activity: Detailed exploration . 8.3.1.14- 43 8.3.1.14.2.2 Study: Laboratory tests and material property measurements ........ 8.3.1.14- 45 8.3.1.14.2.2.1 Activity: Physical property and index laboratory tests..... 8.3.1.14- 45 
8.3.1.14.2.2.2 Activity: Mechanical and dynamic laboratory property tests . . . . 8.3.1.14-48

8.3.1.14.2.3 Study: Field tests and characterization measurements . . . . . . . . . .

8.3.1.14.2.3.1 Activity: Physical property field tests and characterization measurements.......... 8.3.1.14-54

8.3.1.14.2.3.2 Activity: Mechanical property field tests......... . 8.3.1.14- 57

8.3.1.14.2.3.3 Activity: Geophysical field measurements ........ 8.3.1.14- 59

8.3.1.14.2.4 Application of results . . . . . . . . 8.3.1.14-63

8.3.1.14.3 Schedule for the surface characteristics program .

8.3.1.15 Overview of themal and mechanical rock properties program: Description of thermal and mechanical rock properties required by the performance and design issues ........

8.3.1.15.1 Investigation: Studies to provide the required information for spatial distribution of thermal and rechanical properties $8.3 .1 .14-64$ $8.3 \cdot 1.14-53$ $8.3 .1 .15-1$

8.3.1.15.1.1 Study: Laboratory therma properties. $8.3 .1 .15-31$

8.3.1.15.1.1.1 Activity: Density and porosity characterization . . . . . . .

8.3.1.15.1.1.2 Activity: Volumetric heat capacity $8.3 .1 .15-31$ characterization . . . . . . . .

8.3.1.15.1.1.3 Activity: Thermal conductivity characterization........ 8.3.1.15- 36

8.3.1.15.1.2 Study: Laboratory thermal expansion testing . . . . . . . . . . . . .

8.3.1.15.1.2.1 Activity: Thermal expansion characterization......... 8.3.1.15- 38

8.3.1.15.1.3 Study: Laboratory determination of mechanical properties of intact rock.

8.3.1.15.1.3.1 Activity: Compressive mechanical properties of intact rock at baseline experiment conditions.... $8 \cdot 3 \cdot 1.15-34$ $8 \cdot 3 \cdot 1 \cdot 15-38$ $8.3 .1 .15-40$ $8.3 \cdot 1.15-40$

8.3.1.15.1.3.2 Activity: Effects of variable environmental conditions on mechanical properties. . . . . . . .

8.3.1.15.1.4 Study: Laboratory determination of the mechanical properties of fractures...

8.3.1.15.1.4.1 Activity: Mechanical properties of fractures at baseline experiment conditions ..............

8.3.1.15.1.4.2 Activity: Effects of variable environmental conditions on mechanical properties of fractures . . .

$8 \cdot 3 \cdot 1 \cdot 15-41$ $8.3 \cdot 1.15-43$ $8 \cdot 3 \cdot 1 \cdot 15-43$ $8 \cdot 3 \cdot 1 \cdot 15-44$ 
TABLE OF CONTENTS (continued)

8.3.1.15.1.5 Study: Excavation investigations ... 8.3.1.15- 45 8.3.1.15.1.5.1 Activity: Shaft convergence.... 8.3.1.15-46 8.3.1.15.1.5.2 Activity: Demonstration breakout

rooms ............. 8.3.1.15-48

8.3.1.15.1.5.3 Activity: Sequential drift

mining . . . . . . . . . . . 8.3.1.15- 49

8.3.1.15.1.6 Study: In situ thermomechanical properties ............. 8.3.1.15- 52

8.3.1.15.1.6.1 Activity: Heater experiment in

unit TSw1 .......... 8.3.1.15- 52

8.3.1.15.1.6.2 Activity: Canister-scale heater

8.3.1.15.1.6.3 Activity: Yucca Mountain heated

$8 \cdot 3 \cdot 1 \cdot 15-54$

block.......... 8.3.1.15- 57

8.3.1.15.1.6.4 Activity: Thermal stress

measurements.......... 8.3.1.15- 60

8.3.1.15.1.6.5 Activity: Heated room experiment. 8.3.1.15- 62

8.3.1.15.1.7 Study: In situ mechanical properties . 8.3.1.15- 65

8.3.1.15.1.7.1 Activity: Plate loading tests . . 8.3.1.15- 65

8.3.1.15.1.7.2 Activity: Rock-mass strength

experiment .......... 8.3.1.15- 68

8.3.1.15.1.8 Study: In situ design verification . . 8.3.1.15- 70

8.3.1.15.1.8.1 Activity: Evaluation of mining

methods ............ 8.3.1.15- 71

8.3.1.15.1.8.2 Activity: Monitoring of groundsupport sysiems ......... 8.3.1.15- 72

8.3.1.15.1.8.3 Activity: Monitoring drift stability ........... 8.3.1.15-73

8.3.1.15.1.8.4 Activity: Air quality and ventilation experiment ........ 8.3.1.15- 74

8.3.1.15.1.9 Application of results . . . . . . . 8.3.1.15- 76

8.3.1.15.2 Investigation: Studies to provide the required information for spatial distribution of ambient stress and thermal conditions.............. 8.3.1.15- 77

8.3.1.15.2.1 Study: Characterization of the site ambient stress conditions ..... 8.3.1.15-78

8.3.1.15.2.1.1 Activity: Anelastic strain recovery experiments in core holes . . . . . . . . .

8.3.1.15.2.1.2 Activity: Overcore stress experiments in the exploratory shaft facility........... 8.3.1.15-80

8.3.1.15.2.2 Study: Characterization of the site ambient thermal conditions.... . 8.3.1.15-82

8.3.1.15.2.2.1 Activity: Surface-based evaluation of ambient thermal conditions . . 8.3.1.15- 82

8.3.1.15.2.3 Application of results . . . . . . 8.3.1.15-83 
8.3.1.15.3 Schedule for the thermal and rock properties program. . · . · · . . . . . '

$8 \cdot 3 \cdot 1.15-84$

8.3.1.16 Overview of preclosure hydrology program:

Description of preclosure hydroiogic charac-

teristics and conditions required by per-

formance and design issues.......... . 8.3.1.16- 1

8.3.1.16.1 Investigation: Flood recurrence intervals

and levels at potential locations of sur-

face facilities . . . . . . . . . . . 8.3.1.16- 7

8.3.1.16.1.1 Study: Characterization of flood

potential of the Yucca Mountain site. . 8.3.1.16- 10

8.3.1.16.1.1.1 Activity: Site flood and debris

hazards studies ....... 8.3.1.16- 10

8.3.1.16.1.2 Application of results........ 8.3.1.16-13

8.3.1.16.2 Investigation: Iocation of adequate

water supplies.............. 8.3.1.16-14

8.3.1.16.2.1 Study: Iocation of adequate water supply for construction, operation, closure, and decomissioning of a mined geologic disposal system at Yucca

Mountain, Nevada .. . . . . . . . .

8.3.1.16.2.1.1 Activity: Assessment of the cost, feasibility, and alequacy of wells $\mathrm{J}-12$ and $\mathrm{J}-13$ for use as the alternative water supply for a mined geologic disposal system at Yucca Mountain, Nevada . . . . . . . .

8.3.1.16.2.1.2 Activity: Location of a primary water supply for a mined geologic disposal systern at Yucca Mountain, Nevada . . . . . . . . . .

8.3.1.16.2.1.3 Activity: Location of alternative water supplies for a mined geologic disposal system at Yucca Muntain, Nevada . . . . . . . . . . . .

8.3.1.16.2.1.4 Activity: Identification and eval$8.3 .1 .16-22$ uation of potential effects of repository related withdrawals on the local flow system at Yucca Mountain, Nevada......... hydrologic conditions of the unsaturated zone at Yucca Mountain, Nevada . . . . . 
8.3.1.16.3.1.1 Activity: Synthesis of data from site program 8.3.1.2 to determine the preclosure hydrologic characteristics of the unsaturated zone at Yucca Mountain, Nevada.'. . . . 8.3.1.16.3.2 Application of results......... 8.3.1.16.4 Schedule for the preclosure hydrology program

8.3.1.17 Overview of preclosure tectonics: Description of tectonic and igneous events required by performance and design requirements . . . 8.3.1.17.1 Investigation: Studies to provide required
information on volcanic activity that could affect repository design or performance.

8.3.1.17.1.1 Study: Potential for ash fall at the site................

8.3.1.17.1.1.1 Activity: Survey literature regarding Quaternary silicic volcanic centers in the western Great Basin . . . . . . . .. . . .

8.3.1.17.1.1.2 Activity: Assess potential ashfall thickness at the site....

8.3.1.17.1.1.3 Activity: Assess potential particle density and size distribution of ash fall at the site....

8.3.1.17.1.2 Application of results.......... 8.3.1.17.2 Investigation: Studies to provide required information on fault displacement that could affect repository design or performance.

8.3.1.17.2.1 Study: Faulting potential at the repository . . . . . . . . . . . . . .

8.3.1.17.2.1.1 Activity: Assess the potential for surface faulting at prospective sites of surface facilities important to safety . . . . . .

8.3.1.17.2.1.2 Activity: Assess the potential for displacement on faults that intersect underground facilities . . . .

8.3.1.17.2.2 Application of results . . . . . . . 8.3.1.17.3 Investigation: Studies to provide required information on vibratory ground motion that could affect repository design or performance ...............

8.3.1.17.3.1 Study: Relevant earthguake sources . . 8.3.1.17.3.1.1 Activity: Identify relevant earthquake sou
$8.3 .1 .16-26$

$8.3 .1 .16-28$

$8.3 .1 .16-28$

$8.3 .1 .17-1$

$8.3 .1 .17-51$

$8.3 .1 .17-54$

$8.3 \cdot 1 \cdot 17-54$

$8.3 .1 .17-54$

$8.3 .1 .17-55$

$8.3 .1 .17-56$

$8.3 .1 .17-56$

$8.3 \cdot 1.17-60$

$8.3 .1 .17-60$

$8.3 .1 .17-62$

$8.3 .1 .17-63$

$8.3 .1 .17-63$

$8.3 .1 .17-69$

$8.3 .1 .17-69$ 
TABIE OF CONTENTS (continued)

Page

8.3.1.17.3.1.2 Activity: Characterize 10,000-year cumulative slip earthquakes for relevant seismogenic sources... . 8.3.1.17- 72

8.3.1.17.3.2 Study: Underground nuclear explosion

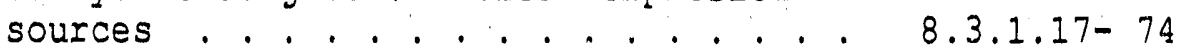

8.3.1.17.3.2.1 Activity: Determine the range of UNE sources .......... 8.3.1.17- 75

8.3.1.17.3.2.2 Activity: Determine maximum underground nuclear explosion source ( $s$ )

8.3.1.17.3.3 Study: Ground motion from regional earthquakes and underground nuclear explosions.

$8.3 .1 .17-74$

$8.3 .1 .17-75$

$8 \cdot 3 \cdot 1 \cdot 17-75$

$8 \cdot 3 \cdot 1 \cdot 17-76$

8.3.1.17.3.3.1 Activity: Select or develop empirical models for earthquake ground motions . . . . . . . . . .

8.3.1.17.3.3.2 Activity: Select or develop empirical models for ground motion from underground nuclear explosions...

8.3.1.17.3.4 Study: Effects of local site geology on surface and subsurface motions?.

8.3.1.17.3.4.1 Activity: Determine site effects from ground-motion recordings . .

8.3.1.17.3.4.2 Activity: Model site effects using the wave properties of the local geology . . . . . . . . . . . . .

8.3.1.17.3.5 Study: Ground motion at the site from controlling seismic events....... 8.3.1.17.3.5.1 Activity: Identify controlling seismic events......... 8.3.1.17-80

8.3.1.17.3.5.2 Aativity: Characterize ground motion from the controlling seismic events.............

8.3.1.17.3.6 Study: Probabilistic seismic hazards analyses . . . . . . . . . . . . . .

8.3.1.17.3.6.1 Activity: Evaluate earthquake

8.3.1.17.3.6.2 Activity: Evaluate ground motion probabilities........ 8.3.1.17-84

$\begin{aligned} & \text { probabilities } . \\ & \text { 8.3.1.17.3.7 Application of results . . . . . . . . . . . } 8.3 .1 .17-84 \\ & 8.3 .1 .17-85\end{aligned}$

8.3.1.17.4 Investigation: Preclosure tectonics data collection and analysis . . . . . . . . . .

8.3.1.17.4.1 Study: Historical and current

seismicity . . . . . . . . . . . . .

$8 \cdot 3 \cdot 1 \cdot 17-81$

$8 \cdot 3 \cdot 1 \cdot 17-82$

$8 \cdot 3 \cdot 1 \cdot 17-82$

$8 \cdot 3 \cdot 1 \cdot 17-86$

$8.3 \cdot 1 \cdot 17-87$

8.3.1.17.4.1.1 Activity: Compile historical earthquake record . . . . . . .

8.3.1.17.4.1.2 Activity: Monitor current seismicity . . . . . . . . .

$8.3 \cdot 1.17-88$

$8.3 \cdot 1.17-89$ 
8.3.1.17.4.1.3 Activity: Evaluate potential for

induced seismicity at the site. . 8.3.1.17-91

8.3.1.17.4.2 Study: Location and recency of faulting near prospective surface facilities............ 8.3.1.17-93

8.3.1.17.4.2.1 Activity: Identify appropriate trench locations in Midway Valley. . 8.3.1.17-93

8.3.1.17.4.2.2 Activity: Conduct exploratory trenching in Midway valley.... 8.3.1.17- 05

8.3.1.17.4.3 Study: Quaternary faulting within $100 \mathrm{~km}$ of Yucca Mountain, including the Walker Lane . . . . . . . . .

8.3.1.17.4.3.1 Activity: Conduct and evaluate deep geophysical surveys in an east-west transect crossing the Furnace Creek fault zone, Yucca Mountain, and the Walker Lane

8.3.1.17.4.3.2 Activity: Evaluate Quaternary faults within $100 \mathrm{~km}$ of Yucca Mountain . .......... $8 \cdot 3 \cdot 1 \cdot 17-105$ Activity: Evaluate the Cedar Mountain earthquake of 1932 and its bearing on wrench tectonics of the Walker Lane within $100 \mathrm{~km}$ of the site............... $8 \cdot 3 \cdot 1 \cdot 17-127$

8.3.1.17.4.3.4 Activity: Evaluate the Bare Mountain fauli zone . . . . . . .

8.3.1.17.4.3.5 Activity: Evaluate structural domains and characterize the Yucca Mountain region with respect to regional patterns of faults and fractures $\cdot \cdot \cdot \cdot \cdot \cdot \cdot \cdot \cdot \cdot \cdot$ $8 \cdot 3 \cdot 1 \cdot 17-128$

8.3 .1 .17 .4 .4

Study: Quaternary faulting proximal to the site within northeast-trending fault zones ............... 8.3.1.17.4.4.1 Activity: Evaluate the Rock Valley fault system............ $8 \cdot 3 \cdot 1 \cdot 17-119$ $8 \cdot 3 \cdot 1 \cdot 17-97$ 8.3 .1 .17 .4 .3 .3

8.3.1.17.4.4.2 Activity: Evaluate the Mine
Mountain fault system . . . . . 8.3.1.17.4.4.3 Activity: Evaluate the Stagecoach Road fault zone . . . . . . . . . . 8.3.1.17.4.4.4 Activity: Evaluate the Cane Spring fault system . . . . . . . . . . $8.3 \cdot 1 \cdot 17-131$ $8 \cdot 3 \cdot 1 \cdot 17-132$ $8.3 \cdot 1 \cdot 17-133$ $8 \cdot 3 \cdot 1 \cdot 17-138$ $8.3 \cdot 1 \cdot 17-139$ $8 \cdot 3 \cdot 1 \cdot 17-142$ 8.3.1.17.4.5 Study: Detachment faults at or proximal to Yucca Mountain....... 
TABLE OF CONTENTS (continued)

$\underline{\text { Page }}$

8.3.1.17.4.5.1 Activity: Evaluate the significance of the Miocene-Paleozoic contact in the Calico Hills area to detachment faulting within the site area . . . . . . . . . .

8.3.1.17.4.5.2 Activity: Evaluate postulated $8 \cdot 3 \cdot 1 \cdot 17-145$ detachment faults in the BeattyBare Mountain area . . . . . . 8.3.1.17-147

8.3.1.17.4.5.3 Activity: Evaluate the potential relationship of brecuia within and south of Crater Flat to detachment faulting . . ..........

8.3.1.1.7.4.5.4 Activity: Evaluate postulated detachment faults in the specter Range and Camp Desert Rock areas.

8.3.1.17.4.5.5 Activity: Evaluate the age of detachment faults using radiometric ages..............

8.3.1.17.4.6 Study: Quaternary faulting within the site area . . . . . . . . . . . .

8.3.1.17.4.6.1 I.ctivity: Evaluate Quaternary geology and potential Quaternary faults at Yucca Mountain . . . . .

8.3.1.17.4.6.2 Activity: Evaluate age and recur$8 \cdot 3 \cdot 1 \cdot 17-155$ rence of movement on suspected and known Quaternary faults . . . 8.3,1.17-157

8.3.1.17.4.7 Study: Subsurface geometry and corcealed extensions of Quaternary faults at Yucca Mountain . $\cdot$ Activity: Evaluate intermediate

8.3.1.17.4.7.1 Activity: Evaluate intermediate
depth (2 to $3 \mathrm{~km})$ reflection and refraction methods and plan potential application of these methods within the site area...... 8.3.1.17-169

8.3.1.17.4.7.2 Activity: Detailed gravity survey of the site area.........

$8 \cdot 3 \cdot 1 \cdot 17-171$

$8.3 \cdot 1.17 .4 .7 .3$ Activity: Detailed aeromagnetic survey of the site area .......

8.3.1.17.4.7.4 Activity: Detailed ground magnetic survey of specific features within the site area .. . . . . . . 8.3.1.17-172

8.3.1.17.4.7.5 Activity: Evaluate surface geoelectric methods and plan potential applications of these methods within the site area...... 8.3.1.17-173 
TABLE OF CONTENTS (continued)

Page

\begin{tabular}{|c|c|c|}
\hline 8.3 .1 .17 .4 .7 .6 & $\begin{array}{l}\text { Activity: Evaluate methods to } \\
\text { detect buried faults using gamma- } \\
\text { ray measurements, and plan } \\
\text { potential application of these } \\
\text { methods within the site area... }\end{array}$ & $8.3 .1 .17-175$ \\
\hline 8.3 .1 .17 .4 .7 .7 & $\begin{array}{l}\text { Activity: Evaluate thermal } \\
\text { infrared methods and plan poten- } \\
\text { tial applications of these methods }\end{array}$ & 0.0 .0 .0180 \\
\hline 8.3 .1 .17 .4 .7 .8 & $\begin{array}{l}\text { Activity: Evaluate shaliow seismic } \\
\text { reflection (mini-sosie) methods } \\
\text { and, if appropriate, conduct sur- } \\
\text { veys of selected structures at and }\end{array}$ & \\
\hline
\end{tabular}

8.3.1.17.4.8 Study: Stress field within and

proximal to the site area ..... 8.3.1.17-179

8.3.1.17.4.8.1 Activity: Evaluat? present stress

field within the site area. . . . 8.3.1.17-180

8.3.1.17.4.8.2 Activity: Evaluate and test shal-

low borehole hydrofrac and triaxial

strain recovery methods for the

determination of in situ stress, and if appropriate, plan potential application of these methods within and proximal to the site.......

8.3.1.17.4.8.3 Activity: Evaluate pubiished and unpublished data on paleostress orientation at and proximal to the site and assess the relevance of these data to Quaternary tectonics . . . . . . .

8.3.1.17.4.8.4 Activity: Evaluate theoretical stress distributions associated with potential tectonic settings (wrench fault, normal fault, detachment fault setting, etc.) of the site........... 8.3.1.17-185

8.3.1.17.4.9 Study: Tectonic geomorphology of the Yucca Mountain region ....... 8.3.1.17-186

8.3.1.17.4.9.1 Activity: Evaluate age and extent of tectonically stable areas at and near Yucca Mountain . . . . . . $8.3 \cdot 1 \cdot 17-183$ $8 \cdot 3 \cdot 1 \cdot 17-182$ Activity: Evaluate extent of areas of Quaternary uplift and subsidence at and near Yucca Mountain . . . 8.3.1.17-189 
8.3.1.17.4.9.3 Activity: Evaluate variations in the nature and intensity of Quaternary faulting within $100 \mathrm{~km}$ of Yucca Mountain through morphometric and morphologic analysis ......

8.3.1.17.4.10 Study: Geodetic leveling . . . .....

8.3.1.17.4.10.1 Activity: Relevel base-station

$8.3 \cdot 1 \cdot 17-194$ network, Yucca Mountain and vicinity . . . . . . . . . . 8.3.1.17-194

8.3.1.17.4.10.2 Activity: Survey selected base stations, Yucca Mountain and vicinity, using global positioning satellite..........3.1.1\%-196

8.3.1.17.4.10.3 Activity: Analyze existing releveling data, Yucca Mountain and vicinity . . . . . . . . . . . 8.3.1.17-197

8.3.1.17.4.11 Study: Characterization of regional lateral crustal movement . . . . . 8.3.1.17-198

8.3.1.17.4.11.1 Activity: Analyze lateral component of crustal movernent based on historical faulting, seismicity, and trilateration surveys . . . .

8.3.1.17.4.12 study: Tectonic models and synthesis . . . . . . . . . . . 8.3.1.17-199

8.3.1.17.4.12.1 Activity: Evaluate tectonic processes and tectonic stability at the site......... 8.3.1.17-200

8.3.1.17.4.12.2 Activity: Evaluate tectonic models ........... 8.3.1.17-203

8.3.1.17.4.12.3 Activity: Evaluate tectonic disruption sequences ...... 8.3.1.17-205

8.3.1.17.4.13 Application of results . . . .... 8.3.1.17-206 8.3.1.17.5 Schedule for postclosure tectonics program 
】

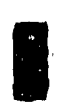

I

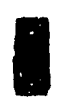

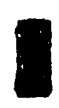

I

INDEX

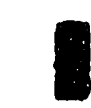

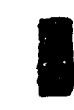

I

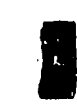

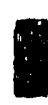

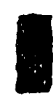

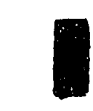

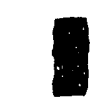

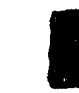

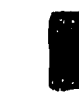

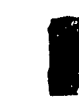

I

A 
A

Abrams et al., 77

Achauer et al., 101, 102

Ackemann, 48

Ackermann et al., 47, 51, 52, 55

aeromagnetic(s), 17, 18, 19, 21,

$23,25,42,47,55,81,108$,

$122,130,137,141,142,144$,

$164,165,167,168,169,171$,

$178,184,185$

aeromagnetic profiles, draped,

17,142

air-gun, 58, 66, 69, 115, 139,

147

aliasing, spatial, 65

Allmendinger, 73

Allmendinger et al., 71, 72

alluvial, 25, 41, 47, 61, 123, 124

alluvial cover, 42, 65, 117

alluvial units, 48,55

alluvial valleys, 143

alluvium, 3, 11, 12, 33, 41, 42,

$48,58,60,64,69,70,72,94$,

$95,108,117,123,136,149$,

$150,165,166,190$

alluvium, pre-Quaternary, 48

alluvium, Quaternary, 58, 61

alteration, 2, 3, 23, 27, 33, 42,

$76,81,86,92,93,112,129$,

$145,148,149,170,177,190$

Amargosa Desert, 25, 42, 48, 58,

$59,107,109,110,123,124$,

$132,139,166,167,168,185$,

189

Amargosa River lineament, 126

Amargosa Valley, 51, 57, 70, 72,

$1.37,144,168,183,185,186$

Amargosa Valley fault, 136

Amargosa Valley test line, 70, 72,145

Ammonia Tanks Member, 12

Anderson, 48, 55, 92, 93, 95

anisotropy, $34,115,122$

anomalies, $5,11,23,25,27,33$,

$70,81,82,101,102,109,112$,

$113,118,120,122,129,137$,

$138,140,142,146,164,169$

aquifer(s), 166 aquifers and aquitards,

Paleozoic, 132

aquitards, 33

argilite, 12, 23, 119

arrival(s), 48, 52, 64, 101, 179

ash fall deposits, 3,57

ash flow (s), 3, 11, 12, 24, 25,

27, 57, 92, 148, 171

Ash Meadows lineament, 126

attenuation, $6 \mathrm{~b}, 72,112,115$,

$116,118,144,151,167,179$

audiomagnetotelluric (AMT), 33,

$34,40,122,143$

B

Bailey et al., 77

Barbier, 60, 73, 151

Bare Mountain, 51, 52, 55, 61

Bare Mountain block, 61

Barry, 62, 73

basalt(s), 12, 17, 23, 25, 26, $27,57,99,168,169$

basaltic volcanism, 102, 137, $138,161,162$

basaltic volcanism, Quaternary, 102

basalts, Quaternary, 17, 23, 27

basement, 5, 11, 12, 27, 33, 34, $42,48,51,58,70,99,102$,

140

wasement, depth, 42

basement, Paleozoic, 11, 34, 42, $51,58,99,102,140$

basement, pre-Cenozoic, 5, 11

$\operatorname{basin}(s), 3,42,58,59,60,61$, $92,102,132$

basins, Tertiary, 58, 59

Basin and Range Province, 57, 71 , 72

Bath, 23, 25, 28

Bath and Jahren, 23, 27, 28, 120, 126,151

Bath et al., 27, 28

Beatty, 2, 48, 51, 59, 60, 75, 108,131

Beatty scarp, 60, 61, 136

bedded tuff $(s), 12,26,92$ 
bedrock, 41, 65, 94, 95, 123, $124,143,149,150,165,171$, 177

Bernero, 156

Beydoun et al., 125, 151

Big Smokey Valley, 59

Birdwell, 61, 62, 85

birefringence, 64

Bish and Chipera, 86, 96

Bishop Ash, 150

Blakely, 27, 28, 109

borehole(s), 11, 24, 34, 45, 47,

$51,52,55,62,85,86,89,90$,

$91,92,93,119,129,139,142$

borehole acoustic televiewer

(BATV), 93, 112, 122，125, 146

borehole control, 45, 55, 69, 120,185

borehole gravimetry, 93, 140

borehole rugosity, $85,86,148$

borehole television, 116, 93,

$112,125,146,148$

boreholes, exploratory, 69, 125, 169

boreholes, c-series, 118, 124, $125,147,159$

boreholes, RF-series, 150

boreholes, UE, 11, 24, 40, 47,

$48,85,93,95,125,150$

boreholes, USW, 24, 62, 85, 93, $115,116,117,118,125,142$,

$145,146,147,167,170$

borings, shallow, 93

Bow Ridge fault, $62,64,143$

Boynton et al., 27, 28

Boynton and Vargo, 18, 28

Brickey, 77

Brocher, 123

Brocher and Hart, 69, 73

Brocher et al., 59, 69, 70, 73, $132,144,145,151,185,186$

Bullfrog Member, 12, 24, 25, 26, 92

Burkhard, 58, 69, 150

Burson, 82

Busted Butte, 3, 11, 136

Byers et al., 11, 13

C

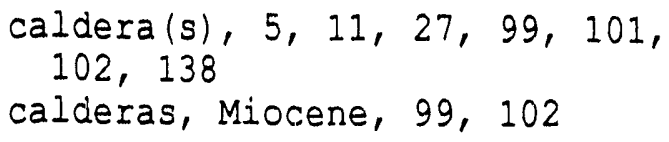

caldera(s), 5, 11, 27, 99, 101, 102,138

calderas, Miocene, 99, 102

calderas, silicic, 138

calibration, $12,70,81,82,94$,

$117,124,158,177,184$

caliche, 48, 123

Calico Hills, $3,23,27,42,47$, 110

Calico Hills tuffs, 12, 26, 92

Calico Hills unit, $3,4,57,92$

Caliente, $6,75,76,77,81$

Cane Spring fault system, 136

carbonate(s), 3, 48, 66, 69, 120, 166

carbonate(s), Paleozoic, 3, 66

Carlin district, 75

Carpetbag fault, 60

Carr, 61

Carr et al., 11, 13

Carr and Yount, 28

Cenozoic, 11, 69, 119, 125, 131.

cesium, 81

cinder cones, 27

clastic(s), 69, 139

$\operatorname{clay}(s), 3,33,93,129$

clipping, 65

cluster analysis, 137

cobalt, 81

COCORP Death Valley Survey', 71

Colorado School of Mines, 61, 62

Colore do plateau, 71

common-depth-point (CDP), 60, 61, $62,64,69,71$

Connard et al., 109

Consortium for Continental.

Reflection Profiling (CCICORP),

$59,70,71,72,107,132$

contact (s) , 24, 33, 42, 57, 66,

$69,70,85,94,95,115,120$,

$123,126,132,140,142,147$,

$149,150,165,166,171,189$,

190

cooling, 2, 3, 24, 25, 27

Cox and Singer, 129, 151

Coyote Wash, 42, 150, 171

Craig and Robison, 93, 96, 119, 151

Craig and Johnson, 119, 151

Crater Flat, 4, 11, 25, 48, 51, $53,55,58,61,65,66,101$, $102,107,109,111,131,136$, $137,138,144,167,168,169$, $178,179,185,189$

Crater Flat Tuff, 12, 23, 24, 25, 26,92

Crowe et al., 23, 27, 28 


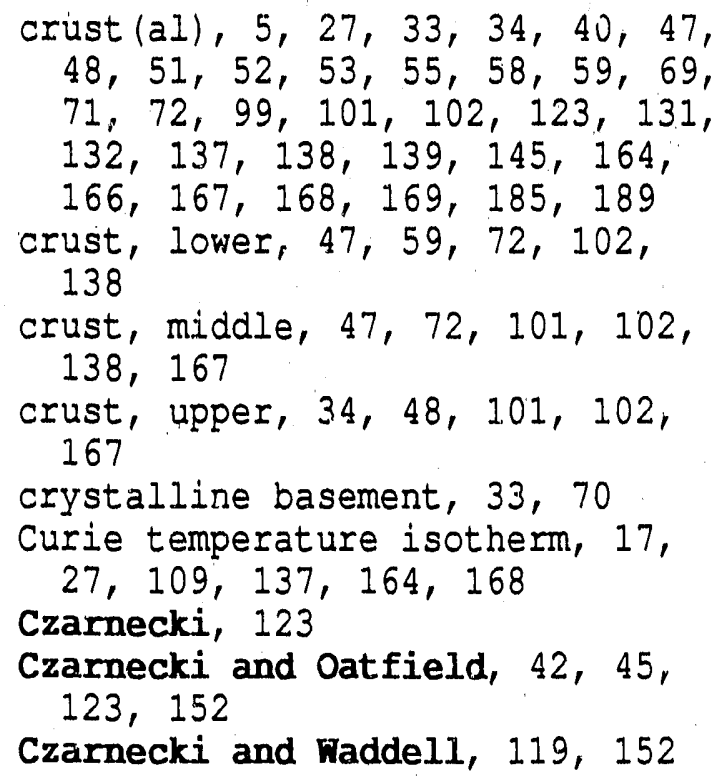

discontinuity, 48,57

dolomite, 12

dolomitic basement, 11

Douglas and Millett, 85, 96

downhole surveys, 48, 52, 65, 69,

$70,116,144,164,167,169$

downhole video camera, 93

Dresser-Atlas, 85

drill core, 23, 24, 26, 69, 137

Drill Hole Wash, 33, 42, 47, 62,

$64,95,120$

drillhole (see borehole)

drilling, 11, 27, 48, 85, 86, 94, $95,116,117,119,122,125$, $139,151,159,160,169,170$, 171

Duval, 83

Duval and Pitkin, 83

\section{E}

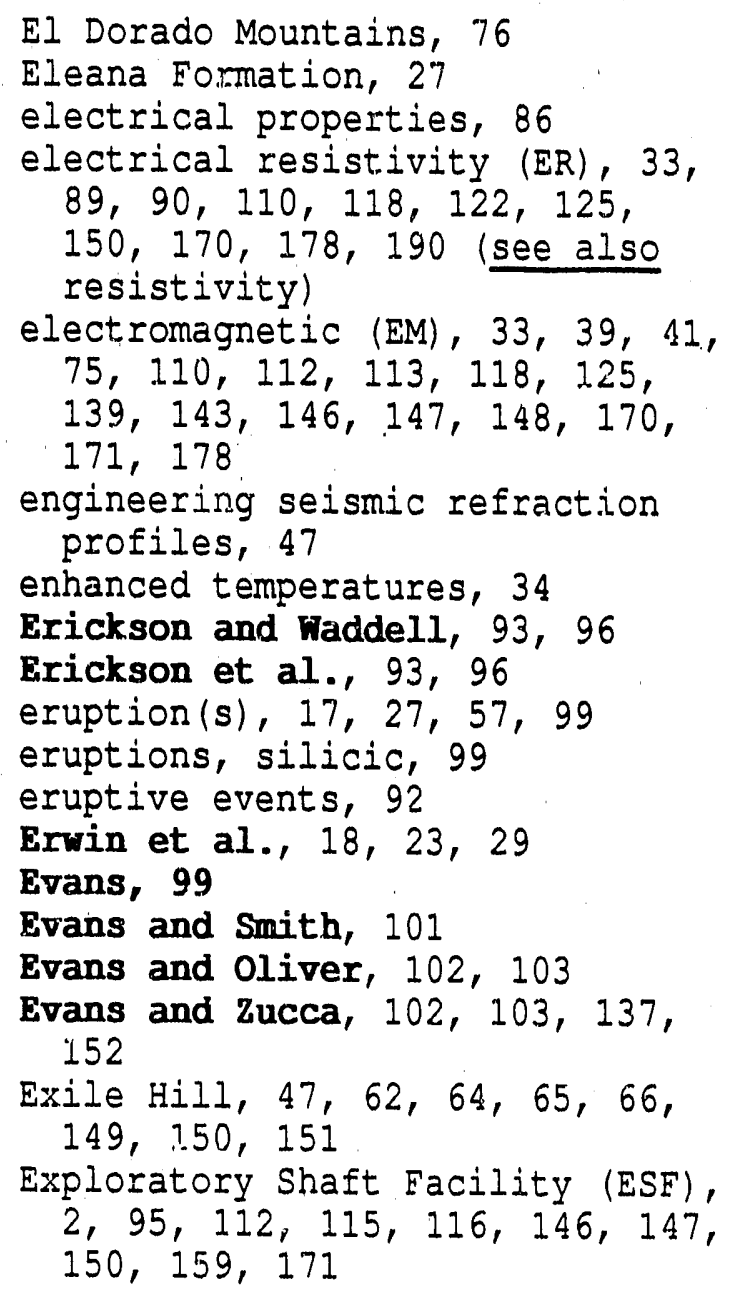


explosive sources, $47,48,51$, $57,58,59,61,62,66,69,70$, $72,115,130,147,150,185$

F

far-field, 115

fault (s), 3, 4, 5, 17, 23, 27, $33,34,39,41,42,45,48,57$, $58,60-62,64,65,69-72,81$, $82,99,109,110,115,118-120$, $123,129-133,136-140,142-150$, $155,158-162,164-166,170$, $177,178,180,189,190$

fault(s), unmapped, 42, 64, 171 fault blocks, 69

fault detection, $33,42,57,65$, $143,164,165,177,190$

fault delineation, 33, 165, 190 fault offset (s), 5, 57, 58, 60, $61,136,137,140,149,150$, 165

fault offset, total, 57

fault scarp, 61

fault slip, 122

fault traces, 81,142

fault zone (s), 33, 57, 60, 110, $112,118,131,132,136,143$, $147,155,170,178$

faulted blocks, 64,72

faulting, post-event, 60

Fe-oxide microcrystals, 25

feasibility testing, $1,105,110$, $113,117,118,120,122,123$, $125,136,137,143,146$

feeder dike, 71, 169, 179

filtering, frequency-wavenumber $(f-k), 64, \quad 35,71$

filtering, velocity, 62

Fitterman, 41, 45, 120, 152

Flanigan, 41, 45

flightline (s), 17, 19, 77, 81, $82,137,142$

Flint, 94, 123, 150

flow, intraborehole, 93

fluid(s), 33, 34, 85, 86, 93, 95, 125,151

Fortymile Wash, 41, 48, 51, 53, $119,123,124,158,169,185$

fracture locations and orientations, 93

fracture pathways, 95, 170

fracture pattern, 76,132
Fran Ridige, 64, 117, 136

Fran Ridge/Alice Hill horst block, 48

Frenchman Flat, 48, 58, 69

Frischknecht and Raab, 39, 45, 120,152

Funeral Mountains, 101, 131

Furgerson, 33, 34, 40, 45

Furnace Creek fault, 131

Furnace Creek fault zone, 131 , 132

G

G-tunnel, 147, 175

Galloway and Erickson, 93, 96 Garden Valley, 59

Geodata International, 83

geoelectric, $1,12,33,34,35$, $37,39-41,42,47,55,110$, $122,126,129,131,139,143$, $162,164,165,168,169,170$, $177,178,189$

geologic mapping, 24, 76, 81, $115,140,171$

geologic units, 2, 11, 12, 24 geophones, 47, 48, 60, 62, 64, $65,49,70,115,116,130,144$, 145,169

geotemperature, 33, 95, 102

Gnojek and Prichystal, 82,84

Goldfield, 6, 18, 75, 77, 81 graben, 102

Grapevine Mountains, 51, 131

Grasty and Darniey, 82, 84 gravity, $1,5,6,7,9,11,12$, $13,47,51,52,55,69,70,85$, $3,102,108,119,120,122$, $123,124,126,129,130,131$, $132,137,139,140,141,142$, $159,160,162,164,166,168$, $169,170,171,178,179,184$, 185,189

Great Basin of Nevada, 129, 166, 167

Greenhaus and Zablocki, 42, 43, $45,120,123,124,152$

ground motion, 5, 51, 130, 132,

$13 \%, 149,150,184,185$

ground roll, 62, 65

ground surveys, 82,168

ground penetrating radar (GPR), $150,160,165$ 
ground-water flow system, 119, $123,124,126$

Guillou, 84

H

Hagstrum et al., 25, 29, 85, 86, 92,96

Hamilton, 55, 131

Eardin, 42, 191

Harding, 65, 136

Harris and Ponce, 12, 13, 185, 186

Harris et al., 13

Hasbrouck, 64, 73, 123, 152

Hauser, 73

Hauser et al., 71

Healey, 13, 140, 152, 185, 186

Healey and Miller, 115, 124, 152

Healey et al., 6, 13, 14, 85, 93, $96,152,184,185,186$

heat flow, 2, 5, 27, 95, 131

Hildenbrand and Kucks, 17, 29, 185,187

Hildenbrand et al., 5, 6, 14, 17, 29

Hill, 18, 23, 29

Hoffman and Kooney, 47, 48, 56, $101,103,185,187$

Holocene, 48

Hoover et al., 34, 41, 42, 45

host rock, 3, 64, 92, 165

Howard and Danbom, 65, 73

Bunt, 77

hydrocarbon, 58, 59, 161, 162

hydrology, unsaturated zone, 94, $115,158,170$

hydrothermal, $75,76,81,111$, $113,129,132$

I

igneous, 5, 33, 123, 132, 137, 164,167

impedance, 69, 120

Indian Springs, 107, 108, 109

induced magnetization, $24,25,26$

induced polarization (IP), 33, $39,85,89,90,91,92,110$, $112,126,148,171,177$

infiltration, 77, 93, 94, 95, $110,117,118,123,124,158$, 159,177

\author{
instrument response, 86, 117, 124 \\ interfaces, steep, 52 \\ interference, 55, 64, 116, 124, \\ 175,179 \\ intrusion(s), 23, 33, 71, 72, \\ $119,123,137,138,164,165$, \\ 167 \\ Iyer, 99, 103 \\ Izett, 14 \\ Izett et al., 150, 152 \\ J \\ Jackass Flats, 48, 51, 69, 107, \\ $109,124,136,144,167$ \\ Jansma et a.., 14, 184, 187 \\ Johnson and Ege, 14 \\ Jones et al., $65,105,144,153$ \\ $\mathbf{K}$ \\ Kane and Bracken, 23, 27, 29, \\ $137,153,185,187$ \\ Kane et al., 6, 11, 14, 27, 29, \\ $119,153,184,187$ \\ Keller, 14 \\ Killeen, 82, 84 \\ Klein, 34, 42 \\ Rlemperer et al., 71, 72, 73 \\ Rnepper, 77 \\ Rnuepfer et al., 72, 73, 131, 153 \\ Koenigsberger ratio, 24, 26 \\ Rrohn, 78 \\ Krohn et al., 78 \\ Kruse, 78 \\ Rruse et al., 78 \\ Rruse and Raines, 78
}

I

Lahond et ai., 93, 96

Landsat MSS, 75, 76

Landsat thematic mapper, 75, 111, 132,161

large hydraulic gradient area, $27,107,110,162,119,120$, $121,122,123,139,145,155$, $161,162,164,167,169,170$, $177,178,190$

Las Vegas, $6,66,75,76,77,81$, 100 
I.as Vegas shear zone, 58,66

Lathrop Wells, 18, 23, 59, 61, 69,168

lateral contrasts, 42

lateral discontinuity, 57, 123

lavas, rhyodacite, 12

limestone, 12

limonitic surface materials, 76

lineaments, $76,126,132,136$, $158,161,163$

listric faults, 69

Iithic Ridge Tuff, 12, 26

Little Skull Mountain, 111

logging, 1, 85, 86, 89, 90, 93, $94,95,116,117,123,124$, $125,149,151,158,159,160$, 177,186

Long Valley, 101

Lovberg and Mose, 82

Lovborg et al., 84

Love waves, 64

$\mathbf{M}$

Mabey, 119, 153

magna, 122, 130, 137

magma bodies, 70, 72, 131, 137, 138

magma chamber(s), 33, 99, 101, 138

magma chambers, silicic, 99, 138

magma source, 102, 138

magmatic intrusion(s), 71, 164

magnetic(s), 12, 17, 23, 24, 25,

$26,27,28,41,70,86,91$,

$108,116,117,119,120,122$,

$126,129,130,131,132,137$,

$139,142,148,159,160,162$,

$164,168,169,171,177,178$,

$179,184,185,189$

magnetic susceptibility, 23, 25,

$27,89,90,92,116,148$

magnetite, 23, 27, 92

magnetotelluric (MT), 33, 34, 40,

$109,120,121,122,130,132$,

$137,143,144,169,170,171$,

178

mantle, upper, 99, 101, 138, 164 mapping, $11,24,25,42,47,57$,

$59,72,76,77,75,81,115$,

$124,130,140,146,147,148$

150,171

Marvin et al., 12, 14
McArthur and Burkhard, 58, 69, $70,74,107,136$

McGovern, 61, 62, 63, 64, 65, $107,144,145,153$

McGovern et al., 58, 74

melt(s), partial, 99, 102, 179

Mesozoic, 27, 66

Mid Valjey, 58, 69, 70, 107

Midway Valley, $33,47,48,52$, $62,149,150,160,165,167$, 178

Mine Mountain fault, 136

Mini-Sosie, 57, 58, 60, 61, 65, $107,122,133,136,137,139$, $145,150,158,160,161,165$, $175,180,189$

Minster et al., 101, 103

Miocene, 11, 99, 101, 102, 132, 139,171

modeling, $11,23,34,39,40,93$, $108,113,114,122,123,149$, $151,156,164,169,181$

modeling, off-axis, 48, 70, 72 Moho, 47, 59, 70, 72, 99, 102, 138,164

moisture, 85, 86, 92, 93, 94, 95, $112,116,117,118,123,124$, $146,147,148,149,170,186$ Mojave Desert, 71

Monfort and Evans, 99, 101, 103

Monitor Valley, 59

Mono Craters, 101

Mooney and Schapper, 47, 51, 56

Morelli, 14

Nuller and kibler, 85, 86, 97

\section{N}

National Science Foundation, 70 National Uranium Resource Evaluation (NURE), 17, 18, 81, 82

Nevada Test Site (NTS), 1, 3, 6, $11,17,24,35,48,57,58,66$, $69,70,81,82,85,100$, $101,119,138,143,175$

Niblack, 78

Nimick and Schwartz, 97

noise, $51,55,62,65,70,71$, $72,142,144,145,167$ nonwelded, $2,3,11,25,45,86$, 92,190 
0

O'Leary et al., 78

O'Leary and Pohn, 79

$O^{\prime}$ Leary and Friedman, 78

ODEX drilling system, 94, 117

offset(s), 57, 61, 64, 120, 136,

$137,140,149,150,165$

oil and gas exploration, 66, 67

Oliver, 123

Oliver and Carle, 120

Oliver and Ponce, 17, 29

Oliver et al., $6,11,15$

Osgood Mountains, 75

outcrop (s), 23, 25, 64, 101, 111

$\mathbf{P}$

Pagany Wash, 123

Pah Canyon Member, 12, 25, 26

Pahranagat, 108

Pahrump Valley, 59, 66

Pahute Mesa, 11, 108,

Paillet, 146, 153

Paintbrush Canyon fault, 48, 143

Paintbrush Canyon-Busted Butte fault zone, 136

Paintbrush Tuff, 3, 12, 23, 24, $25,26,27,42,45,92$

paleomagnetic, $17,23,24,25$,

$111,137,185$

paleotectonic history, 71

Paleozoic, 12, 42, 55, 69, 101, $111,119,123,125,126,129$, 132,138

Paleozoic-Miocene contact, 132

Paleozoic-Tertiary contact, 66 , $69,70,120,166,171,189,190$

Pankratz, 47, 48, 49, 51, 52, 56, $120,123,145,150,153,185$, 187

partially welded, 3,11

petrophysics, 86, 91, 114, 149

perching, 94

percolation, 109, 116, 118, 143

photogeology, 57

Pitkin, 82, 84

Pitkin and Buffman, 82, 84

Pitkin and Duval, 84

plate motions, 99

plutons, 5

Podwysocki et al., 79

Poisson ratio, 151 polarization, $33,93,126,148$, 171

polarization signatures, normal, 92

polarization signatures, reversed, 92

Ponce, 15, 23, 29, 126, 153

Ponce and Hanna, 119

Ponce et al., $6,15,184,187$

pore $(s), 33,34,92,149$

porosity, 2, 3, 33, 86, 91, 92,

$93,116,148,149,160$

potassium, 81,82

pre-Cenozoic, 5, 11

pre-Quaternary, 48

pre-Tertiary, 55, 71, 72, 125,

126

Precambilan, 12, 132

precipitation, $86,94,95,118$

properties, physical, 86,92 , $126,149,151$

Prow Pass Member, 12, 24, 26, 92, 145

Purdy and Rowan, 79

Purdy et al., 79

$Q$

quartzite, 12

Quaternary, 12, 17, 23, 27, 48, $58,61,102,126,131,132$, $136,138,139$

$\mathbf{R}$

radioactivity, $81,143,177$

radioelement (s) , 81, 82, 129, 143

radioisotopes, 81

Railroad Valley, 59

Raines, 79

Rainier Mesa, 3, 64

Rainier Mesa Member, 12, 26, 60

Rainier Mesa tuff, 60

Ramirez, 153

Ramirez and Daily, 147

ray-tracing, 48,51

recharge, 119, 123, 124, 158

reflection Moho, 71, 72

reflections, intrabasin, 69

reflections, mid-crustal,

seismic, 71,72 
reflector(s), 51, 61, 64, 65, 69, $72,139,147,164,165$

remanent magnetization, 23, 24, $25,26,27,92$

remote sensing, $57,75,76,110$, $118,129,130,131,143,177$

repository block, 2, 25, 42, 102, $107,139,140,146,148,155$, $170,178,190$

resistivity, $33,39,40,41,42$, $45,91,92,93,110,112,113$,

$117,119,120,122,123,124$,

$125,126,146,147,148,150$,

$170,171,177,190$ (see also

electrical resistivity)

resolution, $55,101,115,131$,

$137,138,142,143,145,147$,

$148,165,189$

resource exploration, 66

Reynolds, 64, 65, 150, 151

Robbins et al., 85, 93, 97

Roberts et al., 6, 15

Robinove, 79

Robison, 119, 153

Robison et al., 119, 153

rock alteration, 33

Rock Valley, 48

Rock Valley fault, 136

Rodriguez and Yount, 47, 48, 56, 136,150

Rosenbaum, 24, 29

Rosenbaum and Rivers, 23, 30

Rosenbaum and Hudson, 24, 30

Rosenbaum and Schlinger, 25, 30

Rosenbaum and Snyder, 24, 25, 26, 30

Rosenbaum and Spengler, 25, 30

Ross and Lunbeck, 39, 46

Rowan et al., 80

Rowan and hetlaufer, 80

Rowan and Purdy, 80

runoff, 86,95

Rush et al., 93, 97, 119, 153

$\mathbf{S}$

Saltus, 5, 6, 15, 184, 187

Saltus and Ponce, 17, 30, 185, 187

Saltus and Snyder, 17, 30, 185, 187

San Erancisco Mountain, 101
Sandia National Laboratories

(SNL), 187

Sandy speculative survey, 59

Sass et al., 27, 30, 95, 97

saturated zone (SZ), 3, 85, 86,

$90,112,116,118,119,123$,

$124,125,126,146,148,159$, 178

Sawatzky, 80

scatter(ing), 34, 52, 61, 72, $112,115,145$

Schlinger et al., 25, 30

Schlumberger sounding(s), 33, 34, $39,42,43,123,143$

Scott and Bonk, 145, 154

Scott and Castellanos, 52, 56

Scott and Rosenbaum, 24, 30 SCP Sections

8.3.1.2, 110, 175

8.3.1.2.1.3, 112, 169

8.3.1.2.1.3.1, 158, 161

8.3.1.2.1.3.2, 1.58, 161, 162, 163

8.3.1.2.1.3.3, 158

8.3.1.2.2.1, 112, 159

8.3.1.2.2.1.1, 107, 158, 160, $161,163,177$

8.3.1.2.2.1.2, 117, 118, 158, 159

8.3.1.2.2.1.3, 117

8.3.1.2.2.2.3, 158

8.3.1.2.2.3, 107, 112, 149, 178

8.3.1.2.2.3.1, 116, 158

8.3.1.2.2.3.2, 107, 115, 116, $118,147,148,158,159,170$, 177,179

8.3.1.2.2.3.3, 159

8.3.1.2.2.4, 112, 159

8.3.1.2.2.4.2, 112

8.3.1.2.3.1, 159, 169,

8.3.1.2.3.1.3, 124

8.3.1.2.3.1.4, 124

8.3.1.2.3.1.5, 124

8.3.1.2.3.1, 159, 178

8.3.1.2.3.1.1, 159

8.3.1.2.3.1.2, 159, 161，162， 178

8.3.1.4, 175

8.3.1.4.1.2, 1, 105, 116, 126, $129,130,138,155,156,167$, 177,183

8.3.1.4.2, 105

8.3.1.4.2.1, 139, 149, 167, 169

8.3.1.4.2.1.1, 139 
8.3.1.4.2.1.2, 107, 122, 123， $145,158,159,169$

8.3.1.4.2.1.3, 85, 111，112， $113,117,148,151,158,159$, $160,177,178$

8.3.1.4.2.1.4, 114

8.3.1.4.2.1.5, 111, 137, 160

8.3.1.4.2.2, 139

8.3.1.4.2.2.3, 112, 113, 116, $122,125,146,158,159,160$, 170,178

8.3.1.4.2.2.4, 158, 160

8.3.1.4.2.2.5, 107, 113, 115, $147,159,160,167,170,175$, 179

8.3.1.4.3.3.1, 116, 148, 159, 160

8.3.1.5.1.2.2, 139, 179

8.3.1.5.2.1.3, 158, 161, 162, 163

8.3.1.8, 4

8.3.1.8.1.1, 137, 160, 161, 162

8.3.1.8.1.1.3, 131, 137, 138, 179

8.3.1.8.2.1.3, 137

8.3.1.8.5, 139

8.3.1.8.5.1, 137, 160, 161, $162,178,179$

8.3.1.8.5.2.1, 109, 137

8.3.1.9.2.1, 171

8.3.1.9.2.1.2, 162

8.3.1.9.2.1.4, 130, 161

8.3.1.14.2.3, 150, 151, 160

8.3.1.14.2.3.3, 108, 113

8.3.1.15.1.1.1, 160

8.3.1.17, 4, 149, 175

8.3.1.17.1, 137

8.3.1.17.4, 105

8.3.1.17.4.1.2, 137, 160, 179

8.3.1.17.4.2, 108, 149, 150, 160

8.3.1.17.4.2.1, 158, 162

8.3.1.17.4.3, 130, 137, 164, 179

8.3.1.17.4.3.1, 72, 107, 108, $109,130,131,132,137,144$, $161,166,178$

8.3.1.17.4.3.2, $111,161,162$

8.3.1.17.4.3.5, 111, 130, 132, 161

8.3.1.17.4.4, 107, 158, 160, 161

8.3.1.17.4.4.1, 136

8.3.1.17.4.4.2, 136
8.3.1.1.7.4.4.3, 136

8.3.1.17.4.4.4, 136

8.3.1.17.4.5, 137

8.3.1.17.4.7, 137, 138, 139, $164,171,178,179$

8.3.1.17.4.7.1, 70, 107, 123, $144,145,159,161,166,178$

8.3.1.17.4.7.2, 108, 122, 137, $139,159,160,162,169,178$

8.3.1.17.4.7.3, 108, 122, 137, $142,144,162$

8.3.1.17.4.7.4, 109, 122, 1.37, $142,159,162,168,169,177$, 185

8.3.1.17.4.7.5, 110, 122, 123, $143,162,168,169,170,177$, 178

8.3.1.17.4.7.6, 110,143,162, 177

8.3.1.17.4.7.7, 110, 118, 163, 177

8.3.1.17.4.7.8, 107, 133, 136, $137,145,158,160,161,175$, 180

8.3.1.17.4.9.1, 111, 1.36, 161

8.3.1.17.4.12.1, 108

sedimentary, $11,12,33,34,40$, $59,62,66,92$

Seisdata, 58, 59, 61, 62

seismic basement, 48,70

seismic, intermediate-depth, 57,

$66,69,70,144,189,127,135$

seismic reflection, $12,47,55$,

$57,58,59,62,63,67,122$,

$123,127,130,131,133,135$,

$136,137,138,139,144,145$,

$150,155,164,165-171,175$,

183-186, 189-190.

seismic reflection, shallow, 60 , $64,65,66,107,108,109,136$

seismic reflection, shallow

high-resolution, 57

seismic reflectors, shallow, 61 seismic refraction, $11,12,47$, $49,51,52,55,120,123,124$,

$126,130,131,136,137,139$,

$144,145,150,164,166,167$,

$169,171,184,185,186,189$

seismic refraction, shallow, 47 , $52,107,108,123,150,158$

seismicity, 131, 137, 160

Senterfit et al., 39, 46, 120, 154

Serpa, 58 
Serpa et al., 59, 65, 71, 72, 74, 132,154

Serra, 116

shear wave, $64,65,107,115$, $125,139,150,151,165,179$

Shephard, 150

Shoshone Mountain, 110

shot hole(s), 51, 52, 72, 150

signatures, $45,92,99$

Silent Canyon, 138

Silent Canyon caldera, 11, 101

Site Characterization Analysis (SCA), 156

Site Characterization Technical Planning Basis, 105, 155

Skull Mountain, 5:, 111

sledgehammer source, 48, 64, 139, 150

Smith and Ross, 39, 42, 45, 46

Smith et al., 120, 154

snowmelt, 86,94

Snyder and Carr, 6, 11, 12, 15, $51,52,56,119,126,14 \mathrm{C} 154$

Snyder and oliver, 23, 30

Snyder et al., 5, 15, 184, 187

Solitario Canyon, 102, 159

sorting, 60, 61, 62

Southern Great Basin, 6, 100, 179

Southern Great Basin (SGB)

Seismic Network, 33, 99, 100, 101

spectral discrimination, 76

spectral whitening, 60

Spence, 101, 103

Spengler et al., 85, 86, 97

Spring Mountains, 66

Stagecoach Road fault, 136, 143

statics, 70, 144

statics, residual, 61,62

station(s), $1,7,9,23,33,34$, $62,64,71,93,99,100,101$, $102,139,140,142,178,184$

Stauber, 101, 103

Stovepipe Wells, 107, 108, 109

stress field, 119

stress measurement (s), 2, 5, 122, $124,131,146$

strike-slip, 61

structural rotation about a horizontal axis, 24, 60, 178

structural rotation about a vertical axis, 17, 23, 24, 27 subsurfiace, 4, 11, 12, 17, 42, $57,70,125,136,137,145$, $146,166,171,179,182$

subsurface bodies, 42

subsurface characterization, 57

subsurface extension(s), 60, 132, 168

subsurface faul.ting, 61

subsurface geometry, 60, 70, 131, 138

sulfides, 112, 129

sulfide mineralization, 33, 112, 126

surface facilities, 47, 64, 108, $113,142,149,150,151,162$, 165

surface hydrology, 75

surface mapping, 11

surface outcrops, 23, 25

Sutton, 51, 56, 124, 154, 185, 188

Swadley and Hoover, 61

swath-type profiles, 62

Swedish and German repository programs, 146

Syncline Ridge, 42

synthetic aperture radar (SAR) mosaics, 76

$\mathbf{T}$

Tarantula Canyon; 61, 65

Taylor, 101, 103

tectonic(s), $1,2,3,5,12,47$, $48,66,71,105,122,129,130$,

$132,138,139,143,145,155$,

$160,164,166,171,185,189$

teleseismic, 5, 99, 101, 102, $137,164,167,168,169$

teleseismic tomography, 1, 5, 99, $100,137,138$

teleseismic velocity, 33

telluric soundings, 33,34

telluric ratio, 34,143

tensor impedance modeling, 34

Tertiary, $12,25,55,120,126$,

$161,162,166,171,189,190$

thermal infrared, 75, 77, 110, 118

thermal/mechanical, 160

Thirsty Canyon Tuff, 69

thorium, 81, 82

Tikaboo Valley, 59 
Timber Mountain, 11, 12, 18

Timber Mountain Tuff, 23, 26, 60, 69

Timber Mountain caldera, 11, 27, 138

Timber Mount ain-Oasis Valley caldera complex, 102, 138

Timber Mount:ain-Silent Canyon, 99,138

Tiva Canyon Member, 3, 12, 24, $25,26,27,45,48$

Tonopah, 27

topography, 2, 17, 39, 42, 51, $57,81,86,119,139,140,142$, $143,170,189$

Topopan Spring, 18, 48

Topopah Spring Member, 3, 4, 12 , $24,25,26,45,48,64,85,92$, 111,148

Tram Member, 12, 24, 25, 26, 92

transport properties, 92

travel time (s), 51, 55, 60, 65, $69,70,72,101,132,138$

traverses, 12, 23, 37, 108, 109, $123,127,131,132,136,142$, $143,144,166,169,170,178$, 180

Trench 14, 64

trenches, 61

trenches, mapped, 48

trenching, 149, 150, 165

tuff $(s), 2,3,4,11,12,23,24$, $25,26,27,42,45,51,60,64$, $65,69,70,86,92,93,94$, $99,101,102,117,119,120$, $125,138,140,147,148,150$, $167,189,190$,

\section{ర}

underground nuclear explosion(s) (UNES) , 48, 51, 60, 101, 185 United States Geological Survey (USGS) , 2, 18, 26, 27, 30, 31, $40,42,47,48,51,57,58,60$, $61,65,69,72,74,75,76,80$, $81,82,85,124,126,129,131$, $136,145,146,150,185$

unsaturated zone (UZ), 3, 85, 86, $94,112,115,116,117,118$, $120,123,124,125,146,147$, $148,158,170,177,178,179$, 186 upper-crustal profile(s), 51, 52, 124

upper-crustal refraction, 47, 51, $53,55,123,124,137,139$,

$145,166,169,185$

upper-crustal structure, 47, 55, 131

uranium, $17,81,82,126$

USGS Nuclear Hydrology Project, 86

USGS Remote Sensing Tape Library, 75

U.S. Department of Energy (DOE), $17,18,28,29,81,83,99$, $105,146,155,171,181,182$, 183,186

U.S. Nuclear Regulatory Commission (NRC), 99, 156, 165, $166,168,171,181,182$

V

velocity, $47,48,51,52,55,60$, $61,62,64,65,66,69,70,86$, $91,92,93,99,101,102,115$, $116,120,131,138,139,145$, $149,151,164,167,169,184$, $185,189,190$

vertical seismic profiling (VSP), $107,115,116,118,125,144$, $147,148,159,160,167,170$, $175,178,179,189$

vertical seismic profiling (VSP), hydrophone, 125

VHF tomography, 118, 125, 147 vibrator source, 57, 60, 61, 62, $66,69,70,72,115,116,139$, 147,170

Vibroseis, 58, 59, 66, 71, 72, 107,145

vitrophyre (s), 3, 69

volcanic(s), 23, 24, 25, 26, 27, $28,34,40,47,52,55,57,61$, $65,75,99,102,109,120,129$, $132,137,139,142,148,156$, $160,161,162,164,167,168$, $169,179,189$

volcanic cones, 61

volcanic dike, 119

volcanic eruption, 160

volcanic units, 24, 124, 129

volcanics, Tertiary, 42, 66, 124 
volcanism, 101, 102, 130, 161,

$162,164,168,169,179,185$

volcanism, Miocene, 11, 101, 102,

132,139

$\pi$

Waddell, 119, 154

Wahmonie, 23, 42, 47

Walch, 101, 103

Falch and Phillips, 101, 103

Walker Lane, 34, 72, 76, 131, 132

Ward, 84

warping, 60

Wasatch Cordilleran hingeline, 58

water, meteoric, 118, 143

water table, 3, 69, 92, 93, 110,

$111,112,115,120,123,146$,

151,169

weapons testing, 66,70

weight-drop source, 57, 151

welded (and welding), $2,3,4$,

$11,25, \overline{85}, 86,92,117,147$, 190

White River Valley, 59

Thitfield et al., 93, 97

Windy Wash fault, 61,65

Finograd and Thordarson, 119, 154

Wingate Wash fault, 71

Fright, 147

Fynn and Roseboom, 105, 154

$\mathbf{x}$

$x$-ray diffraction, 86

$\mathbf{Y}$

Yeates and others, 82,84

Yucca Flat, 24, 58, 69, 111, 150

Yucca Elat basin, 60

Yucca fault, 60

Yucca Mountain Member, 12, 26

Yucca Mountain profile, 51

Yucca Valley, 27

Yucca Wash, 145
Z

zeolite(s), 3, 93, 129, 148

zeolitization, 93, 112

Zumberge et al., 12, 15, 185 

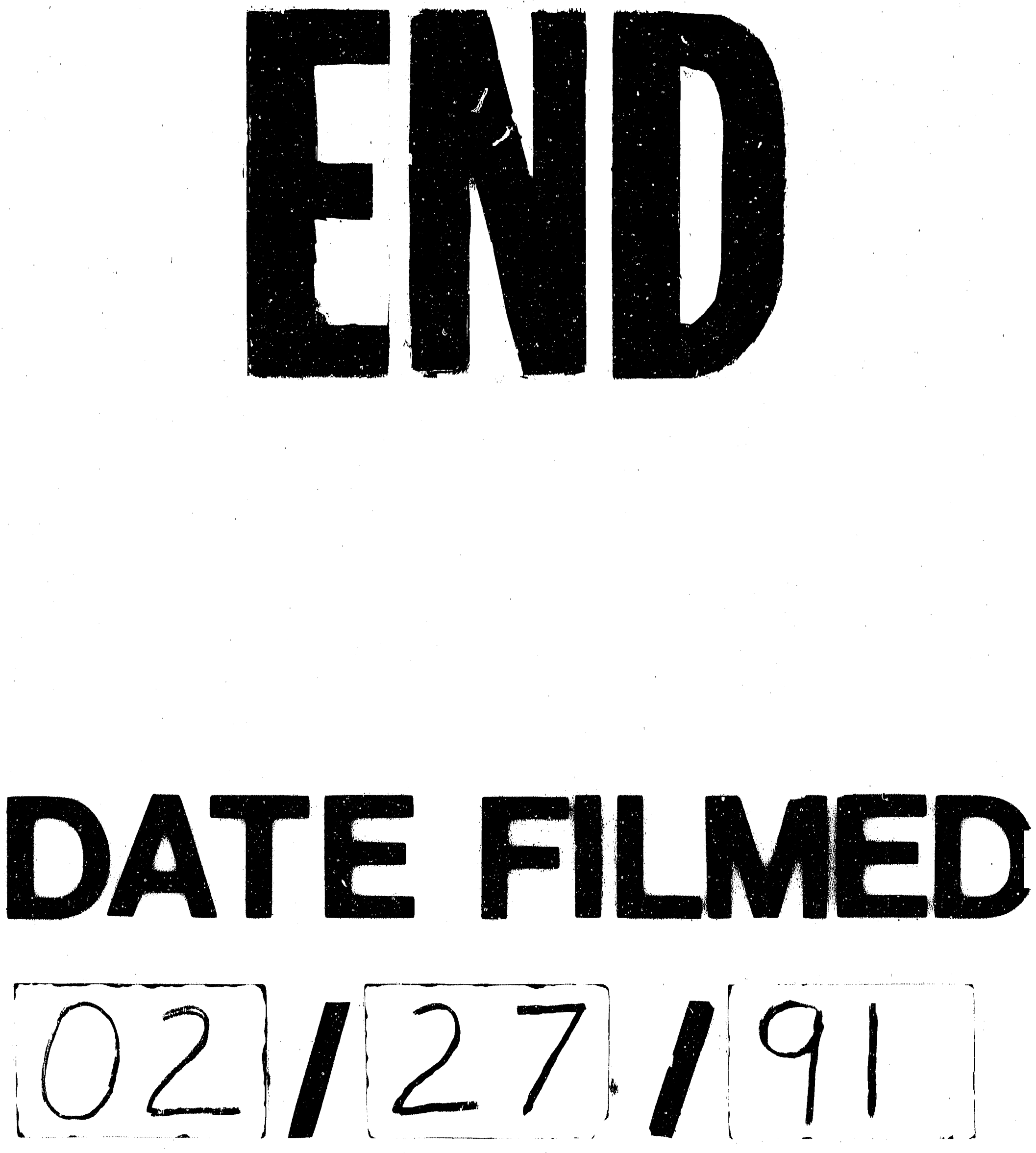
